\title{
Allocation of taxing rights in Tax Treaties between Developing and Developed countries
}

Citation for published version (APA):

Garfias von Fürstenberg, G. (2021). Allocation of taxing rights in Tax Treaties between Developing and Developed countries: Re-thinking principles. [Doctoral Thesis, Maastricht University]. Maastricht University. https://doi.org/10.26481/dis.20210331gg

Document status and date:

Published: 01/01/2021

DOI:

10.26481/dis.20210331gg

Document Version:

Publisher's PDF, also known as Version of record

\section{Please check the document version of this publication:}

- A submitted manuscript is the version of the article upon submission and before peer-review. There can be important differences between the submitted version and the official published version of record.

People interested in the research are advised to contact the author for the final version of the publication, or visit the DOI to the publisher's website.

- The final author version and the galley proof are versions of the publication after peer review.

- The final published version features the final layout of the paper including the volume, issue and page numbers.

Link to publication

\footnotetext{
General rights rights.

- You may freely distribute the URL identifying the publication in the public portal. please follow below link for the End User Agreement:

www.umlib.nl/taverne-license

Take down policy

If you believe that this document breaches copyright please contact us at:

repository@maastrichtuniversity.nl

providing details and we will investigate your claim.
}

Copyright and moral rights for the publications made accessible in the public portal are retained by the authors and/or other copyright owners and it is a condition of accessing publications that users recognise and abide by the legal requirements associated with these

- Users may download and print one copy of any publication from the public portal for the purpose of private study or research.

- You may not further distribute the material or use it for any profit-making activity or commercial gain

If the publication is distributed under the terms of Article $25 \mathrm{fa}$ of the Dutch Copyright Act, indicated by the "Taverne" license above, 
GONZALO JOSÉ GARFIAS VON FÜRSTENBERG

\begin{abstract}
Allocation of taxing rights in Tax Treaties between Developing and Developed countries. Re-thinking principles.

$\mathrm{PhD}$ Thesis
\end{abstract}

Thesis presented at

Maastricht University for the obtaining of the $\mathrm{PhD}$ degree on International Taxation, under the supervision of Prof. Dr. Rainer Prokisch and Prof. Dr. Hans van den Hurk.

Maastricht University

Maastricht

2021 
Acknowledgements

First and foremost, I would like to express my deepest gratitude to my supervisors, Prof. Dr. Rainer G. Prokisch and Prof. Dr. Hans van den Hurk, for their continuous support, patience, and mainly, for believing in this project. Both provided me with invaluable guidance, expertise, and the necessary freedom to do what I considered was right. They gave me constructive contributions and feedback during the whole process. I am also thankful to the assessment committee for spending invaluable time to read my manuscript and for their valuable comments on my dissertation.

I am grateful to my colleagues and friends at Maastricht University, namely Dr. Sofia Ramiro, Mr. Goncalo Cardoso Pereira, Mr. Tonis Vahessar, Dr. Tiiu Albin, Dr. Esperanza Buitrago, Dr. Thomas Kipka, Dr. Frank Nellen, Dr. Mark Kawakami, Dr. Jiangqiu Ge, and Dr. Willem Loof.

Moreover, I would like to extend my gratitude to all the colleagues I had the pleasure of working with in practice during these years, specifically Mr. Francisco Javier Allende, Ms. Carolina Gazitúa, Mr. Jose Luis Ibañez, Mr. Felipe Allende, Mr. Andres Bustos, and Mr. Pablo Ibañez. All of them have supported me during the process, and I'm eternally and truly grateful.

Lastly, I would like to express my heartfelt and loving gratitude to my wife María Paz, to my daughters Isidora, Olivia, and Inés, and to my parents Gonzalo y María Theresa, who have all unstintingly supported this endeavor and to whom I am dedicating this book. Their contributions to my life will be felt forever.

Thank you María Paz for your love and support. 


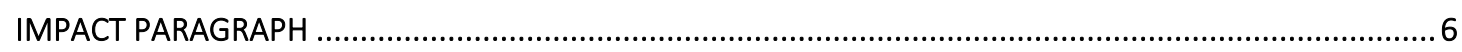

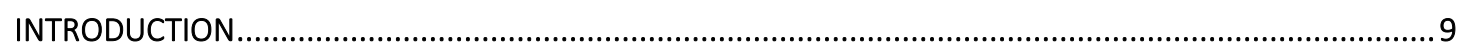

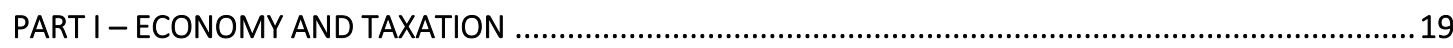

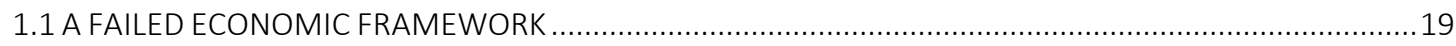

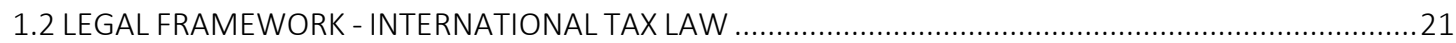

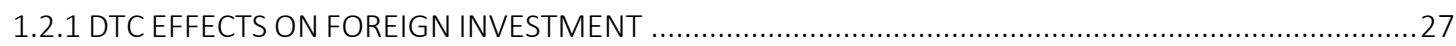

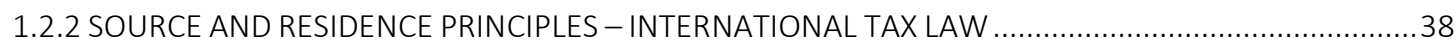

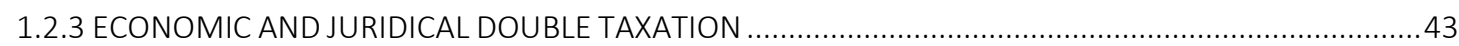

1.2.4 DTC ALLOCATION OF TAXING RIGHTS - ECONOMIC THEORIES .....................................................49

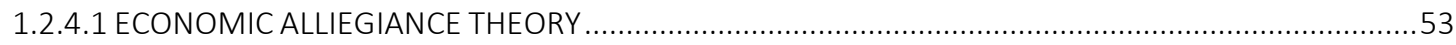

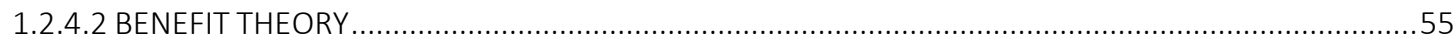

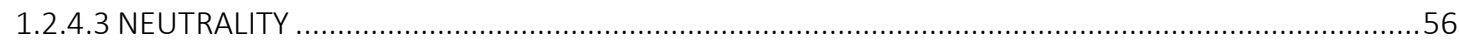

1.2.4.4 THEORIES APPLIED TO PASSIVE INVESTMENT INCOME- LEAGUE OF NATIONS - OECD MTC - UN

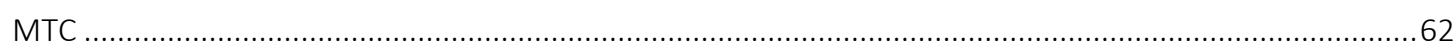

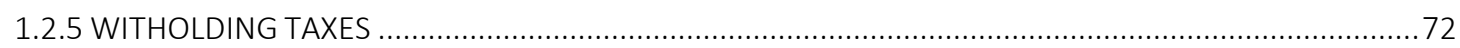

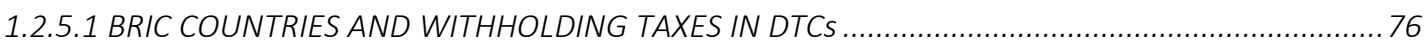

1.3 UN MTC TREATMENT OF ACTIVE AND PASSIVE INVESTMENT INCOME ..........................................78

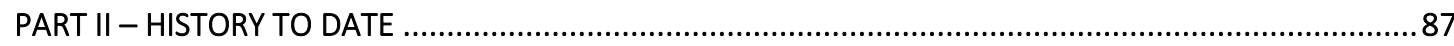

2.1 DEVELOPING COUNTRIES' CLAIMS OF TAXING RIGHTS - MTC CONTEXT ........................................87

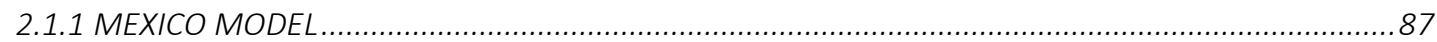

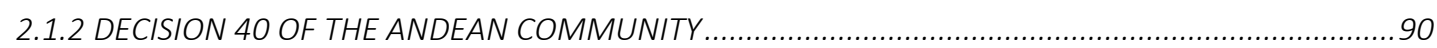

2.1 .3 UN MODEL TAX CONVENTION ............................................................................................... 92

2.2 EXPERIENCES OF OTHER MTCS REGARDING TREATMENT OF PASSIVE INVESTMENT INCOME ............96

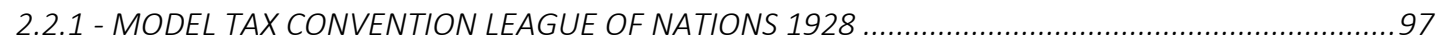

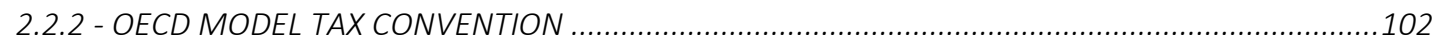

2.2.2.1 - FISCAL COMMITTEE APPROACH - DIVIDENDS TAXATION ................................................. 105

2.2.2.2 - FISCAL COMMITTEE APPROACH - INTEREST TAXATION ..................................................... 108

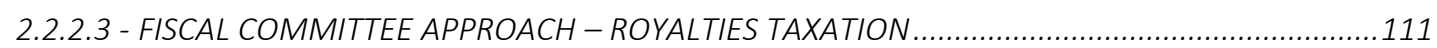

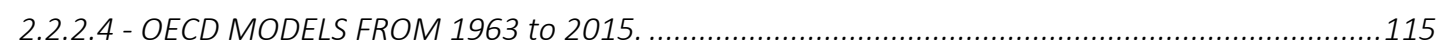

2.3 CURRENT UN AND OECD MTCS RULES REGARDING PASSIVE INVESTMENT INCOME TAXATION ........120

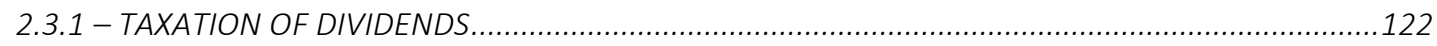

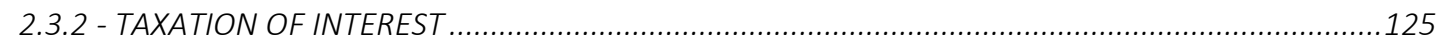

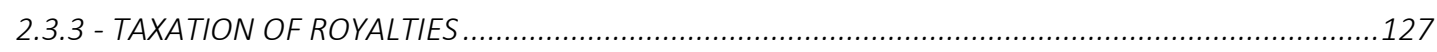

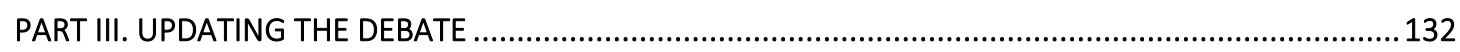

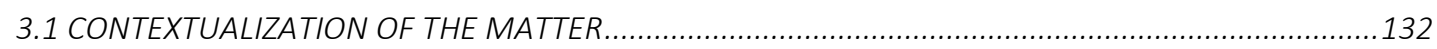

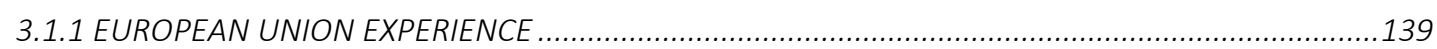

3.1.2 TAX SPARING CLAUSES / MATCHING CREDITS ...................................................................... 144

3.1.3 BILATERAL INVESTMENT TREATIES AND DOUBLE TAX CONVENTIONS ...................................149

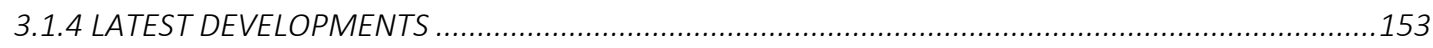

PART IV. DIVIDENDS: TESTS, NEW PROPOSAL, DIVIDEND TAXATION AND THE UN MODEL...................165 4.1 PRELIMINARY CONSIDERATIONS OF FOREIGN DIRECT INVESTMENT AND FOREIGN PORTFOLIO

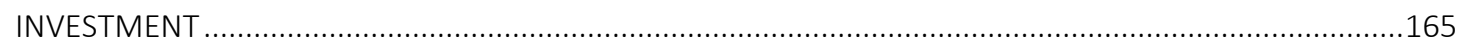

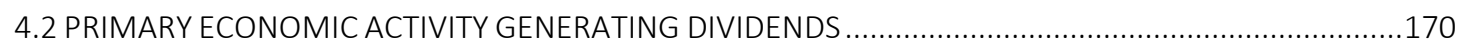

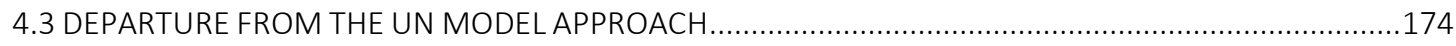

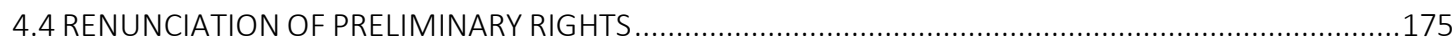

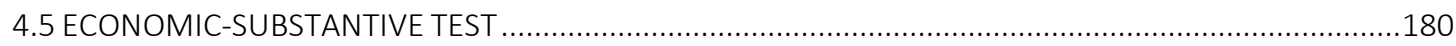

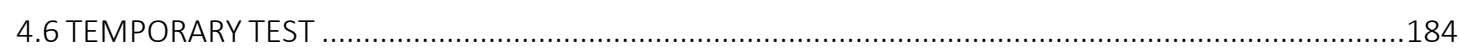

4.7 PROPOSAL FOR DIVIDEND TAXATION AND THE ELIMINATION OF DOUBLE TAXATION ...................185

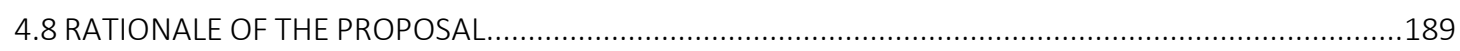

PART V. INTEREST: TESTS, NEW PROPOSAL, INTEREST TAXATION AND THE UN MODEL..................... 192 
5.1 PRELIMINARY CONSIDERATIONS: DEDUCTIBLE EXPENSE FOR THE BORROWER, INCOME TAXED TWICE IN THE HANDS OF THE LENDER, NON-ECONOMIC DOUBLE TAXATION ...................................192

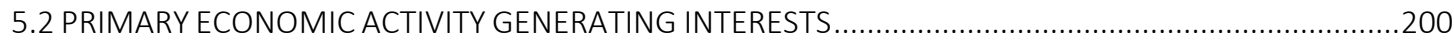

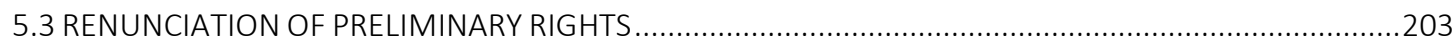

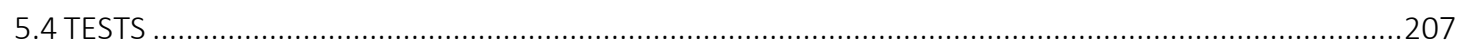

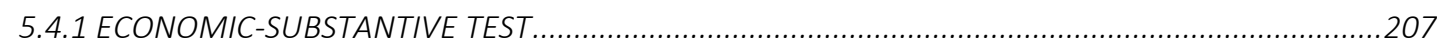

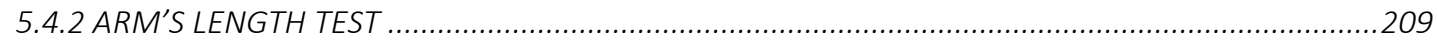

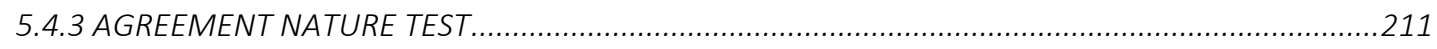

5.5 PROPOSAL FOR INTEREST TAXATION AND THE ELIMINATION OF DOUBLE TAXATION ...................212

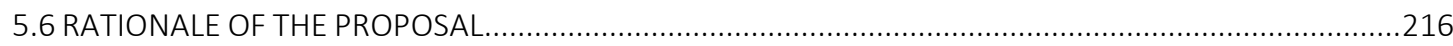

PART VI. ROYALTIES: TESTS, NEW PROPOSAL, ROYALTIES TAXATION AND THE UN MODEL ................218

6.1 PRELIMINARY CONSIDERATIONS: DEFINITION OF ROYALTIES .........................................................218

6.2 TOTAL ALLOCATION OF TAXING RIGHTS TO THE COUNTRY OF RESIDENCE OECD MTC ...................230

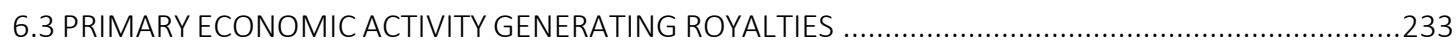

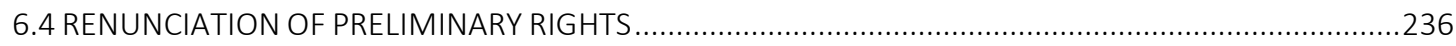

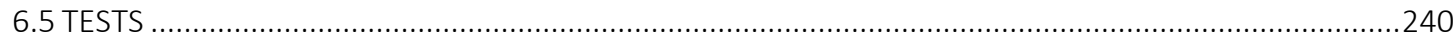

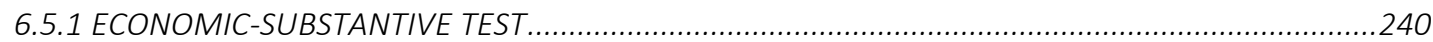

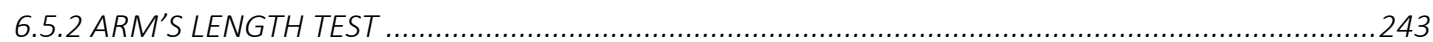

6.6 PROPOSAL FOR ROYALTY TAXATION AND THE ELIMINATION OF DOUBLE TAXATION ....................244

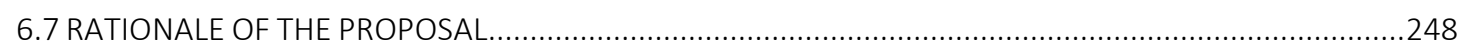

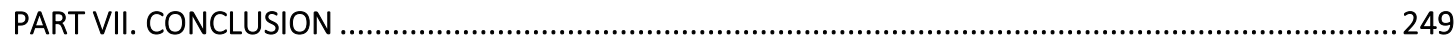

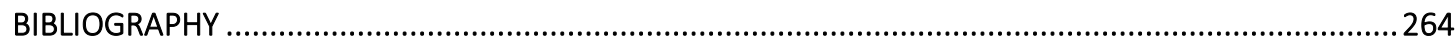

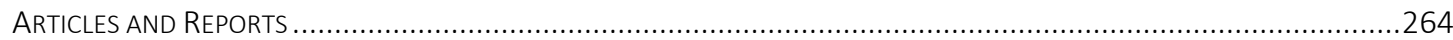

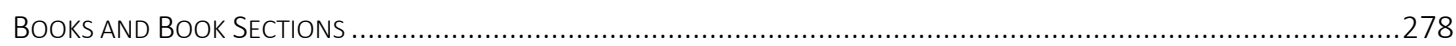

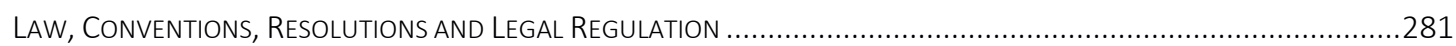

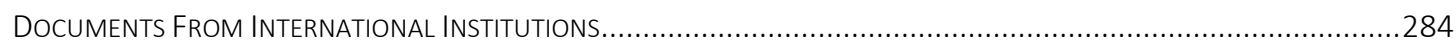


ABBREVIATIONS

BEPS - Base Erosion and Profit Shifting

BITS - Bilateral Investment Treaties

BRICS - Brazil, Russia, India, China and South Africa

CEN - Capital Export Neutrality

CIN - Capital Import Neutrality

DTCs - Double Tax Conventions

EC - European Commission

ECOSOC - United Nations Economic and Social Council

FDI - Foreign Direct Investment

FPI - Foreign Portfolio Investment

GDP - Gross Domestic Product

GRP - Goods, Rights, or Property

IBFD - International Bureau of Fiscal Documentation

ICC - International Chamber of Commerce

IMF - International Monetary Fund

LN - League of Nations

MAP - Mutual Agreement Procedure

MLI - Multilateral Convention to Implement Tax Treaty Related Measures to Prevent Base

Erosion and Profit Shifting

MNEs - Multinational Enterprises

MOF - Minister of Finance

MTC - Model Tax Convention

OECD - Organization for Economic Cooperation and Development

OEEC - Organization for European Economic Cooperation

PPT - Principal Purpose Test

UN - United Nations

US - United States

UNCTAD - United Nations Conference on Trade and Development

WTO - World Trade Organization 
The aim of this doctoral thesis is to determine whether the criteria / principles which govern the treatment of passive investment income in double taxation conventions (DTCs) between developing and developed countries are effective and appropriate for the interests of developing countries.

This research was conducted in a period totally overwhelmed by the concept of tax abuse, and therefore, cross-border erosion of countries' tax bases. In that context and taking into consideration that I am strongly if not doggedly motivated to understand the underlying justification of the principles that history and society impose on us as natural truths, I exerted great effort to think out of the box regarding diagnostics, reality, and potential solutions. Moreover, the effort expended to avoid being influenced by the ideological pressure that international organizations have historically put on developing countries. The analysis and outcome travelled a unique route, granting independence in the intent of collaborating not only with developing but also with developed countries by offering fresh concepts that could help in the challenging task of grant fairness in DTCs between developing and developed countries. This was done with the understanding that, at least for developing countries, DTCs must help in the route to development.

The study analysed the economic aspects underlying the principles that have governed the allocation of taxing rights in DTCs between developing and developed countries plus the historical evolution of those DTCs. Elements such as attracting foreign investment, access to useful foreign debt, and access to useful technology were considered by the author as the most relevant elements when questioning a DTC's treatment of dividends, interests, and royalties, respectively. Relevant facts were discussed and examined, including that current international tax policy on this matter is focused on the developed world, and that historical concessions made by developing countries are the reason for the actual state of the matter. The right to development is also included in the analysis. The combination of elements demonstrates that a fair international tax equilibrium and sound tax policy therefore need to 
be found. The author believes that the needs of developing countries to raise their economies and to protect their domestic tax base should not be disregarded or silenced.

On the practical side, the research starts from the premise that DTCs between developing and developed countries do not contribute on the route of developing countries to development. The rationale behind this premise is that DTCs only focus their efforts on the elimination of international double taxation, a role well assumed as evidenced in the positive evolution of domestic laws in the last decades. This study questioned the historical tendency of developing countries' negotiators who, when negotiating s DTC with developed countries, put as a priority the amount of taxing rights. The author criticizes this approach and puts development before taxation. Due to the lack of doctrine on the matter, it is possible to find, throughout the whole work, the author's own ideas as a basis for proposals. If the proposals are executed, it is expected that benefits will accrue to all actors, i.e. to developed countries, to developing countries, to investors resident in developed countries, and to investors resident in developing countries. Special expectations are in relation with the assistance in the development process of developing countries through the increment of beneficial foreign investments, easy access to useful foreign debt, and easy access to beneficial technology/intangibles. Although DTCs alone cannot determine the success of economic growth and development, they can nevertheless aid in this process.

The actual worldwide public health crisis that we are facing is hitting the whole world hard. Developing countries will be tremendously affected and economic inequalities will only be exacerbated. This crisis has already sharply exposed the global economy's pre-existing weaknesses, setting back development progress around the world. The crisis will potentially make the goal of development for many developing countries fade into the background and generate a drastic change in the order of priorities. As most politicians and economists from the developing world are already commenting, focusing on recovering jobs, migration, health, and access to food will be the challenges of developing countries probably for the next decade. On this unfortunate scenario, this work can contribute to re-thinking international tax principles that govern the allocation of taxing rights in DTCs with direct effect on incentives to foreign investments, access to useful foreign debt, and access to useful 
technology. The author is convinced that these changes could incentivize trade and investment and, therefore, help to enhance developing countries' economies with the aim of staying true to the route to development.

Finally, and regarding the proposals, all of them share the same principle: eliminate tax obstacles generated by DTCs in the interaction of developing and developed economies. The above can be achieved by taxing only at one level. In simple words, the author proposes principles similar to those that sustain the taxation of dividends, interests, and royalties in the European Union - internal market - to be applied in DTCs between developing and developed countries. The criteria used by the author to determinate which country should keep the taxing right was to analyse in-depth the economic link between income and the relevant country. 


\section{Introduction}

This research focuses on the rules concerning the taxation of dividends, interest and royalty income within the context of Double Taxation Conventions (DTCs) between developing and developed countries. The aim of this research is to determine whether the criteria / principles which govern the treatment of those incomes are effective and appropriate for the interests of developing countries. The development of developing countries and fairness regarding the allocation of taxing rights will therefore be the two core elements that are considered by the author throughout this research.

Passive income refers to the income in respect of which, broadly speaking, the recipient does not participate in the activity that gives rise to the income, e.g., dividends, interest, rental income, and royalties. ${ }^{1}$ It is a term that is generally used to describe investment income when there is a lack of control or involvement over the source that actually generates the income. One economic definition of the term passive income is "cash flow obtained without continuous time involvement". ${ }^{2}$

This research defines the incomes that will be examined, i.e., dividends, interest and royalties, as "Passive Investment Income". This concept is used so as to group these three different types of income into one single category, with the aim of streamlining references to them throughout the course of this examination. Within those categories, dividends can be, according to the level of control or involvement over the investment that generates the income, considered as dividends derived from business investments, when there is a certain degree of control / involvement (Foreign Direct Investment or FDI) ${ }^{3}$ or, by way of contrast,

\footnotetext{
${ }^{1}$ OECD Glossary of Tax Terms. Available at: http://www.oecd.org/ctp/glossaryoftaxterms.htm

${ }^{2}$ Copeland, Thomas E., Weston J. Fred, and Shastri, Kuldeep. Financial Theory and Corporate Policy, $4^{\text {th }}$ ed. (New Jersey: Prentice Hall, 2003), 1024.

${ }^{3}$ OECD Glossary of Foreign Direct Investment Terms and Definitions. "Foreign direct investment (FDI) is a category of investment that reflects the objective of establishing a lasting interest by a resident enterprise in one economy (direct investor) in an enterprise (direct investment enterprise) that is resident in an economy other than that of the direct investor. The lasting interest implies the existence of a long-term relationship between the direct investor and the direct investment enterprise and a significant degree of influence on the management of the enterprise. The direct or indirect ownership of $10 \%$ or more of the voting power of an enterprise resident in one economy by an investor resident in another economy is evidence of such a
} 
as dividends derived from capital investments (Foreign Portfolio Investment or FPI), ${ }^{4}$ which is also known as income that arises from holding securities such as foreign stocks, bonds, or other financial assets, none of which entails active management, control, or involvement on behalf of the investor. ${ }^{5}$

Notwithstanding that, in the strict sense, we should not refer to income derived from business investments or income derived from an investment where there is some involvement associated therewith as passive income, and leaving the concept of passive income only to dividends derived from capital investments, interest, and royalties, this research nevertheless does so. The aim is to give more relevance to the real impact of the investment in the host / source / developing country and to disregard other factors. As such, this research will refer to all dividends as passive income and it will only differentiate between them as and when it is necessary to do so.

The approach mentioned above is also influenced by the fact that the concept of control has not been incorporated in DTCs so as to actively differentiate between active and passive income ${ }^{6}$ leaving the concept of active income to the income that is gained from the "activity pursued" - involvement - in the territory, ${ }^{7}$ and therefore not taxing the income derived from FDI / business investments as active income.

relationship. Some compilers may argue that in some cases an ownership of as little as $10 \%$ of the voting power may not lead to the exercise of any significant influence while on the other hand, an investor may own less than $10 \%$ but have an effective voice in the management. Nevertheless, the recommended methodology does not allow any qualification of the $10 \%$ threshold and recommends its strict application to ensure statistical consistency across countries.". Available at: https://www.oecd.org/daf/inv/investment-policy/2487495.pdf ${ }^{4}$ OECD Glossary of Foreign Direct Investment Terms and Definitions. "A portfolio investment in a company would be a holding of shares amounting to a small portion of the total shares of the company, e.g. less than 10\%. Portfolio investors may receive different tax relief or other treatment in respect of their dividends under tax treaties from those accorded to other direct investors". Available at: https://www.oecd.org/daf/inv/investment-policy/2487495.pdf

${ }_{5}$ Edited by Boulle, Laurence; Laryea, Emmanuel; and Sucker, Franziska. International Economic Law and African Development. Siber Ink, South Africa, 2014.

${ }^{6}$ Avi-Yonah, Reuven S. Double Tax Treaties: An Introduction. University of Michigan Law School, 2007. Available at:

http://papers.ssrn.com/sol3/papers.cfm?abstract_id=1048441.

7 Bischel, John E. Basic approaches to treaty negotiation. Available at http://www.un.org/esa/ffd/wpcontent/uploads/2014/10/6STM_CRP10_Section1.pdf 
DTCs have been fashionable for several years. These types of international agreements supplement the domestic policy framework in order to achieve the respective economic goals of each country. ${ }^{8}$ As such, DTCs should be the result of sovereign and conscious policy decisions. Over time, however, such goals have naturally changed. While in the beginning, the idea was to remove obstacles to trade ${ }^{9}$ arising as a consequence of double taxation, ${ }^{10}$ nowadays it can be said that DTCs serve other purposes, such as the prevention of tax avoidance and they can even assist in achieving non-tax goals, e.g., the detection of money laundering. ${ }^{11}$

In general, citizens and scholars ${ }^{12} 13$ tend to believe that those international agreements prevent the undesired effects of double taxation while, at the same time, they believe that they are capable of promoting foreign investment. ${ }^{14}$ While the former is true in all cases, i.e., giving legal certainty to foreign investors in the fierce fight for attracting foreign investment, the latter goal is not always achieved. ${ }^{15}$ The complexity of the latter is due to the fact that it

\footnotetext{
${ }^{8}$ United Nations, Department of Economic and Social Affairs, Model Double Taxation Convention between Developed and Developing Countries, 2017. Introduction, Origin: Paragraph 4: "The desirability of promoting greater inflows of foreign investment to developing countries on conditions which are politically acceptable as well as economically and socially beneficial has been frequently affirmed in resolutions of the General Assembly and the Economic and Social Council of the United Nations and the United Nations Conference on Trade and Development."

${ }^{9}$ Braun, Julia; and Zagler, Martin. An Economic Perspective on Double Tax Treaties with(in) Developing Countries. World Tax Journal, 2014. Available at: https://www.ibfd.org/sites/ibfd.org/files/content/pdf/wtj_2014_03_int_4-free-article.pdf

${ }^{10}$ OECD, Model Tax Convention on Income and Capital, 2017. Commentary on Article 26.

${ }^{11}$ OECD, Model Tax Convention on Income and Capital, 2017. Commentary on Article 26.

12 Blonigen Bruce A.; and Davies, Ronald B. Do Bilateral Tax Treaties Promote Foreign Direct Investment? Working Paper 8834, National Bureau of Economic Research, 2002. Available at: https://www.nber.org/papers/w8834.pdf

13 Vallejo Chamorro, José María; and Gutiérrez Lousa, Manuel. Los convenios para evitar la doble imposición: Análisis de sus ventajas e inconvenientes, 2002. Available at:

https://www.cepal.org/ilpes/noticias/paginas/2/11542/jmvallejo.pdf

${ }^{14}$ See Hearson, Martin. When do developing countries negotiate away their corporate tax base?. Journal of International Development, London School of Economics. Vol 20, 2018; and Blonigen, Bruce; and Oldenski, Lindsay. The Differential Effects of Bilateral Tax Treaties. American Economic Journal: Economic Policy. Vol $6 \mathrm{~N}^{\circ}$ 2, 2014.

${ }^{15}$ See: Zagler, Martin; and Zanzottera, Cristiana. Corporate Income Taxation Uncertainty and Foreign Direct Investment. 2012. Available at: https://www.nber.org/papers/w8834.pdf; Baker, Paul L. An Analysis of Double Taxation Treaties and their Effect on Foreign Direct Investment. International Journal of the Economics of Business, Vol 21, 2014; Blonigen, Bruce A.; and Davies, Ronald B. The Effects of Bilateral Tax Treaties on U.S. FDI Activity. International Tax and Public Finance, Vol 11, 2004; and Egger, Peter H. and Larch, Mario and Pfaffermayr, Michael and Winner, Hannes. The Impact of Endogenous Tax Treaties on Foreign Tax Investment: Theory and Evidence. The Canadian Journal of Economics, Vol 39, 2006.
} 
very much depends on the economic flow of trade and investments ${ }^{16}$ between the countries, as well as of the reach of domestic tax law. Therefore, the terms of the agreement reached during the treaty negotiations are very important and so too are the provisions of domestic tax law. Due to the differences between the economies of developed and developing countries, and their different interests, the expectations in relation to DTCs vary between both groups of countries. ${ }^{17}$

Developing countries, considered as an undetermined group of countries, follow the idea that DTCs help to increase economic growth and foster economic development. ${ }^{18}{ }^{19}$ Many developing countries have entered into such agreements on the basis of ascertaining that expectation. $^{2021}$ The author considers the Human Development Index of the United Nations as the most accurate measure to determine the degree of development of countries. ${ }^{22}$

This research casts aspersions over that paradigm. The study will focus on the tax treatment of passive investment income. In order to understand the actual framework regarding the taxation of passive investment income, the author - with the aim of contributing to this debate - will analyse (1) economy and taxation / concepts such as foreign investments and DTCs, among others; and (2) the history of the matter / the evolution of DTCs. If the study gives rise to any proposals, the expectation is to base those proposals on the examination of the economic link between the income and the country of source or the country of residence, complemented with the duty of attracting foreign investments and the access to useful foreign debt and technology in developing countries, as the core principles governing the design of

\footnotetext{
${ }^{16}$ Valencia, Alexis; Barreix, Alberto; and Videla, Luis. Impacto Fiscal en la Integración económica. 2003 Available at: https://publications.iadb.org/handle/11319/6161?locale-attribute=es\&

${ }^{17}$ Vogel, Klaus. Double Tax Treaties and Their Interpretation. International Tax \& Business Lawyer, Vol 4, 1986.

${ }^{18}$ Neumayer, Eric. Do double taxation treaties increase foreign direct investment to developing countries? The Journal of Development Studies, Vol 43, 2007.

${ }^{19}$ Ibid., 9 .

20 Pickering, Ariane. Why Negotiate Tax Treaties?. 2013 Available at: http://www.un.org/esa/ffd/wpcontent/uploads/2013/05/20130530_Paper1N_Pickering.pdf

${ }^{21}$ Baistrocchi, Eduardo. The Use and Interpretation of Tax Treaties in the Emerging World: Theory and Implications. British Tax Review, $\mathrm{N}^{\circ}$ 4, 2008.

${ }^{22}$ See: http://hdr.undp.org/en/content/human-development-index-hdi
} 
a Model Tax Convention (MTC) for use in agreements between developing and developed countries.

The majority of developing countries are high importers of capital and technology, but their exports in these fields cannot, regrettably, be compared to developed countries. This is a feature that is characteristic of many developing countries, and therefore their economic policies - including their tax policies - should not ignore this situation. Some references will be made to Africa and Latin America throughout the course of this study in order to illustrate certain points.

This study refers to developing countries and contends that tax provisions, and in particular DTCs, may influence that status. There are few developing countries that are currently bridging the developing gap. However, what are known as the Four Asian Tigers ${ }^{23}$ and the BRICS are exceptions to this general rule. ${ }^{24}$ Historically, it has been easy to recognize developing countries on the basis of their participation and membership of international organizations. The Organisation for Economic Co-operation and Development (OECD) was regarded as the club for the developed nations. Nowadays, Chile ${ }^{25}$, Mexico ${ }^{26}$, and Colombia $^{27}$, are OECD member countries, whereas Costa $\mathrm{Rica}^{28}$ is currently undergoing the accession process. Furthermore, Argentina, Brazil and Mexico are G20 members. ${ }^{29}$ This does not mean in any way, shape or form, however, that these emerging economies are developing at an equal pace when compared to other OECD countries. For instance, Brazil is a BRICS member, i.e., one of the five major emerging economies, but it is not yet an OECD member, although it is considered to be a "key partner". 30

\footnotetext{
${ }^{23}$ Markle, Kevin S.; and Shackelford, Douglas. Do Multinationals or domestic firms face higher effective tax rates? Working Paper 15091 National Bureau of Economic Research, 2009. Available at: https://core.ac.uk/download/pdf/6646073.pdf

${ }^{24}$ O’Neill, Jim. Building Better Global Economic BRICS. Paper Goldman Sachs Global Economics, 2001. Available at: http://www.goldmansachs.com/our-thinking/archive/archive-pdfs/build-better-brics.pdf

${ }^{25}$ See: http://www.oecd.org/chile/

${ }^{26}$ See: http://www.oecd.org/mexico/

${ }^{27}$ See: http://www.oecd.org/countries/colombia/

${ }^{28}$ See: http://www.oecd.org/latin-america/countries/costarica/

${ }^{29}$ See: http://g20.org.tr/about-g20/g20-members/

${ }^{30}$ See: https://www.oecd.org/about/membersandpartners/
} 
The need for a coherent and coordinated approach from developing countries should be reflected in international tax policy. ${ }^{31}$ Currently, international tax policy focuses on the developed world: countries that have, with some exceptions, similar flows of trade and investment and that, due to the most recent economic crisis, need to be more transparent. Notwithstanding the efforts that have been made to include developing countries in the discussion $^{32}$ of the OECD initiative of Base Erosion and Profit Shifting (the BEPS Report) the process has been, beyond any doubt, predominantly driven by developed countries. ${ }^{33} 34$

Following the BEPS Declaration at the 2013 Ministerial Council Meeting of the OECD and at the request of the Group of Twenty ${ }^{35}$ (G20), in July 2013, the OECD launched a BEPS Action Plan, identifying 15 specific actions that are needed in order to equip governments with the domestic and international instruments to competently address this challenge. This Action Plan was fully endorsed by the G20 Finance Ministers and Central Bank Governors at their meeting in Moscow in July 2013, as well as at the G20 Heads of State at their meeting in Saint Petersburg in September 2013. For the first time ever in relation to tax matters, nonOECD/G-20 countries were involved on an equal footing. ${ }^{36}$ The United Nations formed a BEPS subcommittee, ${ }^{37}$ a subcommittee mandated to draw upon its own experience and engage with other relevant bodies, particularly the OECD, with a view to monitoring developments on base erosion and profit shifting issues and to directly communicate such issues to officials in developing countries and through regional and inter-regional

\footnotetext{
${ }^{31}$ Shome, Parthasarathi. Trends and Future Directions in Tax Policy Reforms: A Latin American Perspective. Working Paper International Monetary Fund, 1992. Introduction.

32 Baez, Andrés. El plan BEPS y Los Países en Vías de Desarrollo (BEPS and Developing Countries. Posdoctoral research fellow IBFD. University Carlos III Madrid, 2017.

${ }^{33}$ Crivelli, Ernesto; De Mooij, Ruud; and Keen, Michael. Base Erosion, Profit Shifting and Developing Countries. International Monetary Fund Working Paper, 2015. Available at: https://www.imf.org/en/Publications/WP/Issues/2016/12/31/Base-Erosion-Profit-Shifting-and-DevelopingCountries-42973

${ }^{34}$ Picciotto, Sol. Informe sobre Erosion de la base tributaria y deslocalizacion de beneficios BEPS. Implicancias para los países en vías de desarrollo. Tax Justice Network, 2014. Available at: https://www.worldpsi.org/sites/default/files/documents/research/es tjn briefing_beps_for_developing_countries.pdf

${ }^{35}$ The Group of Twenty is the premier forum for its members' international economic cooperation and decisionmaking. Its membership comprises 19 countries plus the European Union. G20 leaders meet annually. In addition, Finance Ministers and Central Bank Governors meet regularly during the year to discuss ways to strengthen the global economy, reform international financial institute ions, improve financial regulation and implement the key economic reforms that are needed in each member economy. See in: https://www.g20.org. ${ }^{36}$ See: http://www.oecd.org/tax/beps-about.htm

${ }^{37}$ See: https://www.un.org/esa/ffd/tax-committee/tc-beps.html
} 
organizations. ${ }^{38}$ Notwithstanding the fact that it seems that the matters discussed in the BEPS Report are not related to the allocation of taxing rights regarding passive investment income in DTCs between developing and developed countries, they implicitly are. ${ }^{39}$ Developing countries are called upon to be transparent, to enact "fair" tax laws, while the main issues, such as source versus residence / fair allocation of taxing rights and development, still have to be addressed. The OECD/G20 efforts to combat the base erosion caused by shifting profits does not recognize that this topic very much falls within its scope. ${ }^{40}$

The structure of DTCs exacerbates the conflict between residence and source principles, especially in DTCs between countries that are at different stages of development. Issues related to permanent establishments, the attribution of profits to permanent establishments, as well as the treatment of passive income are salient examples.

A fair international tax equilibrium and sound tax policy therefore needs to be found. The needs of developing countries to raise their economies and to protect their domestic tax base should not be disregarded or silenced. The right to development ${ }^{41}$ of developing nations ${ }^{42} 43$ should not be excluded because of the international policy of developed countries. ${ }^{44}$ DTCs should help developing nations to increase foreign investment, and to access foreign debt and technology. More importantly, the assistance of developed countries to the development of developing and less developed nations should not be limited to aid, ${ }^{45}$ but it should be commensurate with a sound economic global policy, including a tax policy for all and not only for a select group of developed countries. Since this ideal may be regarded as utopian,

\footnotetext{
38 Ibid, 36.

${ }^{39}$ Brauner, Yariv. What the BEPS. Florida Tax Review, Vol 16, 2014.

${ }^{40}$ OECD BEPS Project, Action Plan on Base Erosion and Profit Shifting, 2013. Available at: https://www.oecd.org/ctp/BEPSActionPlan.pdf

${ }^{41}$ United Nations, General Assembly, Declaration on the Right to Development, document A/RES/41/128, Geneva, 1986. Available at:: http://www.un.org/documents/ga/res/41/a41r128.htm

${ }^{42}$ United Nations, Human Rights, The Right to Development at a Glance. Available at: http://www.un.org/en/events/righttodevelopment/pdf/rtd_at_a_glance.pdf

${ }^{43}$ Rich, Roland Y. The Right to Development as an Emerging Human Right. Virginia Journal of International Law, Vol 23, 1983.

${ }^{44}$ Souza de Man, Fernando. Taxation of Cross-Border Provisions of Services in Double Tax Conventions between Developed and Developing Countries: A Proposal for New Guidelines. PhD Thesis Maastricht University, Faculty of Law, 2013.

${ }^{45}$ Braun, Julia; and Zagler, Martin. The true art of the tax deal: Evidence on aid flows and bilateral double tax agreements. World Economy, Wiley, Vol 41, 2018.
} 
developing countries therefore need to strengthen their tax policies and coordinate their efforts in this regard. ${ }^{46}$

Since the scope of proceeds derived from passive investment is ample, this research focuses on gross receipts from dividends (derived from shares of foreign companies' / equity finance), interest (cross-border loans) and royalties (cross-border transfer of technology). And it does so in an approach to DTCs, in particular, to those proposed by international organizations, which are primarily premised on the United Nations Model Tax Convention (UN MTC). ${ }^{47}$ This model follows a classification and assignment method ${ }^{48}$ that is almost a copy of the Organization for Economic Co-operation and Development Model Tax Convention (OECD MTC), which was built on the previous models and the work of the League of Nations (LN). As is stated in their titles, both MTCs are designed to guide the DTCs of developed or industrialized countries with developed, industrialized, or developing countries, and they are not designed for DTCs between developing and developed or industrialized countries. The UN MTC, however, is expected to fill this gap.

From this perspective, alongside determining the rationale behind the actual criteria / principles, the specific goal of this research is to establish whether the UN MTC approach in relation to the taxation of passive investment income is appropriate for DTCs between developing and developed countries.

Lastly, and regarding methodology and structure, the research method of this study departs from the premise that DTCs between developing and developed countries do not contribute on the route of developing countries to development. The rationale behind this premise is that DTCs only focus their effort on the elimination of international double taxation, a role

\footnotetext{
${ }^{46}$ Rodriguez, Saúl Alberto. La armonización tributaria en América Latina. UNMSM Lima, Vol 5, 1998.

${ }^{47}$ United Nations, Department of Economic and Social Affairs, Model Double Taxation Convention between Developed and Developing Countries, 2017. Introduction, Origin of the United Nations Model Convention: Paragraph 1:"United Nations Model Double Taxation Convention between Developed and Developing Countries (the United Nations Model Convention) forms part of the continuing international efforts aimed at eliminating double taxation; Paragraph 4: "The desirability of promoting greater inflows of foreign investment to developing countries on conditions which are politically acceptable as well as economically and socially beneficial has been frequently affirmed in resolutions of the General Assembly and the Economic and Social Council of the United Nations and the United Nations Conference on Trade and Development."

${ }^{48}$ Concept defined further in this study. See: 1.2.4
} 
that has being well assumed by the positive evolution of domestic laws in the past few decades. For the same reason, the limitation to tax that source / developing countries assume under actual DTCs is no longer justified. The author supports this statement by combining historical and conceptual methodology in this research. The historical side was used to show that actual rules governing allocation of taxing rights in DTCs between developing and developed countries were justified in the first stage of evolution of Model Tax Conventions but, due to the positive evolution already mentioned, it can be stated that today those rules shift taxable profits from the source country to the residence country. The conceptual side is present in the whole research. The author, due to the lack of doctrine on the matter, took the challenging path of analysing the original theories that governed the allocation of taxing rights, but also, of including his own abstract ideas as bases to support the proposal. The premise of this conceptual approach was the one that allowed the author to develop a completely new approach to govern the allocation of taxing rights in DTCs between developing and developed countries, an approach that includes development as one of the main goals.

The work is divided in VII Parts. Part I analyses economy and taxation, giving a general description of the economic worldwide environment of the past years and the relation of the above with the location of developing countries in the economic map. Part I also provides an overview of the influence of the legal framework and international tax law on developing countries' stage of development. The core elements of analysis are the role of DTCs as a factor in increasing foreign investment, source and residence principles, economic and juridical double taxation, the principles governing allocation of taxing rights in DTCs, and the UN MTC treatment of active and passive investment income. Part II makes a full historical review of the evolution and principles governing the allocation of taxing rights in DTCs. This Part gives special value to developing countries' influence in the Mexico Model, the Decision 40 of the Andean Community, and the UN MTC. In terms of historical sources, this Part also analyses the treatment of passive investment income in the MTC of the League of Nations 1928, the OECD MTC and the UN MTC from 1963 and 1980 respectively, until today. Part III provides a proper update of the debate. Among other things, this Part conducts an in-depth doctrinal analysis of DTCs and developing countries and the causal relation 
between DTCs and the increase of foreign investments. Topics such as the EU experience, tax sparing clauses and matching credits, and bilateral investment treaties, are closely examined and analysed. Special reference is made in this Part to the latest developments related to the matter, i.e. the Base Erosion and Profit Shifting Reports, the Multilateral Convention to Implement Tax Treaty Related Measures to Prevent Base Erosion and Profit Shifting, and the Principle Purpose Test. Parts IV, V and VI apply tests to dividends, interest, and royalties, respectively, and as an outcome, contain the proposals regarding allocation of taxing rights for these three types of incomes in DTCs between developing and developed countries. Lastly, Part VII contain the conclusions of this research. 


\section{PART I - ECONOMY AND TAXATION}

\subsection{A FAILED ECONOMIC FRAMEWORK}

The world economy has been engulfed in crisis for the last decade. According to the World Economic Outlook of the International Monetary Fund (IMF), the recovery is still weak and precarious. ${ }^{49}$ An analysis of the indicators is worrying, particularly for developing countries. The actual Gross Domestic Product (GDP) growth in 2020 shows that, whilst the value of the annual percentage change in the European Union is 4.7, in the Asian region (Asean/5) it is 8.1 and in the Latin America and the Caribbean regions is $3.6 .^{50}$ The regional inward direct investment positions by region, as of the end of 2019, show that South American countries are at the bottom of this list, with African countries occupying the lowest positions. ${ }^{51}$ No country from either of these regions features in top ten of the Inward Direct Investment ranking. ${ }^{52}$ The same applies regarding Outward Direct Investment. ${ }^{53}$

Furthermore, according to the United Nations Conference on Trade and Development (UNCTAD), the road to global FDI recovery is bumpy and long, especially given the low growth rates. 5455

This status is particularly worrying, especially when one considers its causes and impact. One of the impeding factors for inclusive growth is the competitiveness gap that exists between regions. As the data show, the competitive position of Latin America, as a good example of a group of developing countries, is not very good in this respect. ${ }^{56}$ According to

\footnotetext{
${ }^{49}$ International Monetary Fund, World Economic Outlook. Subdued Demand: Symptoms and Remedies, 2016. Available at: https://www.imf.org/en/Publications/WEO/Issues/2016/12/31/World-Economic-Outlook-October-2016Subdued-Demand-Symptoms-and-Remedies-44024

${ }^{50}$ International Monetary Fund, DataMapper. Real GDP growth annual percent change. Available at: http://www.imf.org/external/datamapper/NGDP_RPCH@WEO/OEMDC/ADVEC/WEOWORLD

${ }^{51}$ See: http://data.imf.org/regular.aspx?key=60564265

${ }^{52}$ See: http://data.imf.org/regular.aspx?key=61227425

${ }^{53}$ See: https://data.imf.org/regular.aspx?key=61227425

${ }^{54}$ UNCTAD, World Investment Report, 2015. p. 2. Available at: http://unctad.org/en/PublicationsLibrary/wir2015_en.pdf

${ }^{55}$ UNCTAD World Investment Report, 2017. p. 10. Available at: http://unctad.org/en/PublicationsLibrary/wir2017_en.pdf

${ }^{56}$ World Economic Forum, The Global Competitiveness Report, 2016-2017. p.11. Available at:
} 
the World Economic Forum, growth rates in the region have fallen, productivity has been falling on average during the last 20 years, exports have not recovered, and several countries are now on the verge of falling into a recession. ${ }^{57}$

Another factor to consider is the FDI imbalance. FDI is fundamental for economic growth for both developed and developing countries. Its importance is so crucial that it is considered a key driver in financing the post-2015 development agenda. ${ }^{58}$ The patterns of FDI inflows and outflows show that the situation for developing nations is not particularly ideal. According to the 2020 UNCTAD Report "developing economies are expected to see the biggest fall in FDI because they rely more on investment in global value chain intensive and extractive industries, which have been severely hit, and because they are not able to put in place the same economic support measures as developed economies" ${ }^{\text {"59 }}$. The Report also states that "overall, 54 economies introduced at least 107 measures affecting foreign investment in 2019; threequarters were in the direction of liberalization, promotion and facilitation, with developing countries and emerging economies in Asia most active”. Investment flows in Africa fell by $10 \%$ to US $\$ 45$ billion and Latin America and the Caribbean are expected to halve in 2020 from the \$164 billion received last year. In 2019, FDI in Latin America and the Caribbean grew by 10 per cent to $\$ 164$ billion, driven by increased flows to Brazil, Chile and Colombia.

In addition to the above, the different models of the digital versus the traditional economy are also worth mentioning. The 2016 UNCTAD Report points out that developing and transition-economy MNEs are slowly closing the productivity gap. According to the report: "The involvement of MNEs from developing and transition countries in the digital economy and related equipment manufacture is resulting in the narrowing of the productivity gap with developed-country MNEs. Improving labour productivity is especially evident in industries

\footnotetext{
https://www.weforum.org/reports/the-global-competitiveness-report-2016-2017-1.

57 Ibid, 56 p. 20.

${ }^{58}$ UNCTAD World Investment Report, 2015. p. 120. The importance of sustainable revenue bases as the largest, surest and most sustainable way of funding development.

${ }^{59}$ UNCTAD, World Investment Report, 2020. p. 4. Available at: https://unctad.org/system/files/officialdocument/wir2020_overview_en.pdf
} 
such as computers, electronics, electrical equipment, textiles and apparel, construction and trade". ${ }^{60}$

The success of the digital economy seems to be exceptional. The improvement in the technological development of developing countries is, however, questionable. In developing nations, apart from the Asian nations, the number of patents, models and similar intellectual property granted is very limited and the data are not comparable with the numbers granted in developed economies.

The statistics pertaining to the internationalization of MNEs worldwide show that their performance in the developing and transition economies is slowly improving, however.

More factors and issues could be pointed out in this regard. This, however, would fall outside the scope of this research. Instead, the aim of this research is to establish how international tax measures, in particular those that are related to the international taxation of passive income within a DTC, fits in the puzzle for growth of the economies of developing countries.

\subsection{LEGAL FRAMEWORK - INTERNATIONAL TAX LAW}

Although corporate taxation is seen as part of the "set of international public-good problems" ${ }^{61}$ the role that has been played by international taxation in that failure has not been the subject of much analysis, except for the attention paid by the OECD in recent years to tax avoidance and tax evasion and its consequences for the erosion of countries' tax bases. According to the UNCTAD World Investment Report, tackling tax avoidance is at the apex of the policy principles, as the image below shows. ${ }^{62}$

\footnotetext{
${ }^{60}$ UNCTAD World Investment Report, 2016. p. 31.

${ }^{61} \mathrm{Ibid}, 48$.

${ }^{62}$ UNCTAD World Investment Report, 2016. p. 207.
} 


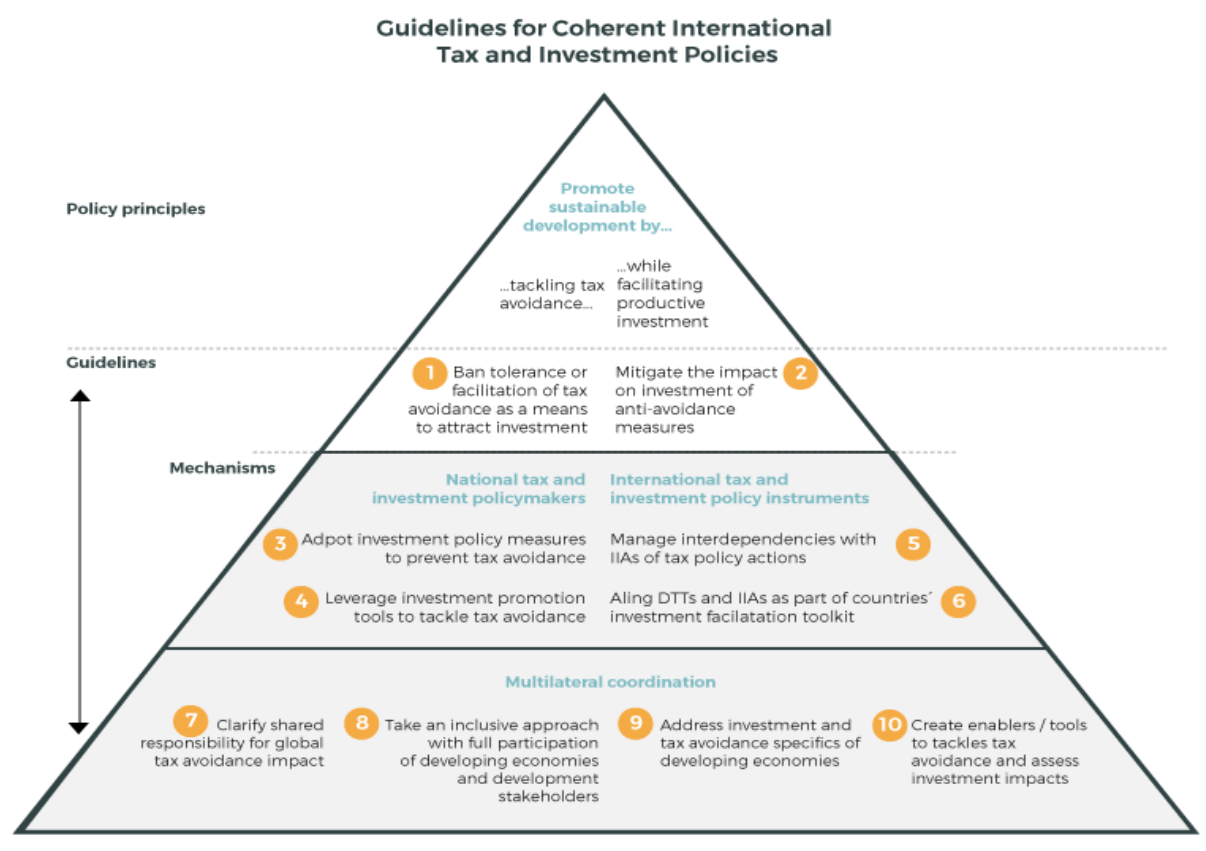

There have been a number of international tax-related issues in the crisis over the last few years, in particular regarding the incomes that are the subject of analysis in this research. For instance, according to the IMF, "Debt bias' (tax provisions favouring finance by debt rather than equity) is now widely recognized as posing a stability risk". ${ }^{63}$ The impact of tax technology-related provisions (e.g. patent boxes), is an example of a tax technological measure that has been challenged by the BEPS Report, ${ }^{64}$ requiring alignment of the benefits of these regimes with substantive research and development activity. ${ }^{65}$

Furthermore, structural approaches to income taxation in developed countries may make useless the many tax technological incentives offered by developing countries in order to

\footnotetext{
${ }^{63}$ International Monetary Fund, Tax Policy, Leverage and Macroeconomic Stability, 2016. Available at: https://www.imf.org/external/np/pp/eng/2016/100716.pdf

${ }^{64}$ OECD BEPS Project: Final Report Action 5: Countering Harmful Tax Practices More Effectively, Taking into Account Transparency and Substance, 2015. Available at:

http://www.oecd.org/tax/countering-harmful-tax-practices-more-effectively-taking-into-accounttransparency-and-substance-action-5-2015-final-report-9789264241190-en.htm

${ }^{65}$ OECD, G20, Explanatory Statement BEPS Project, Final Reports, 2015. Available at: https://www.oecd.org/ctp/beps-explanatory-statement-2015.pdf
} 
attract FDI. ${ }^{6}$ In this scenario investors benefit from DTCs due to the certainty and equality of treatment associated with them. ${ }^{67}$

The role of DTCs in attracting FDI should not be underestimated. Until very recently it was not very common to find statistics regarding the connection between DTCs and foreign investment. Legal scholars normally took for granted the fact that DTCs are beneficial to the economy of the source country. However, the latest figures in the UNCTAD World Investment Report suggest otherwise. The fiscal contribution of foreign affiliates of MNEs is not particularly high, as the image below shows. ${ }^{68}$
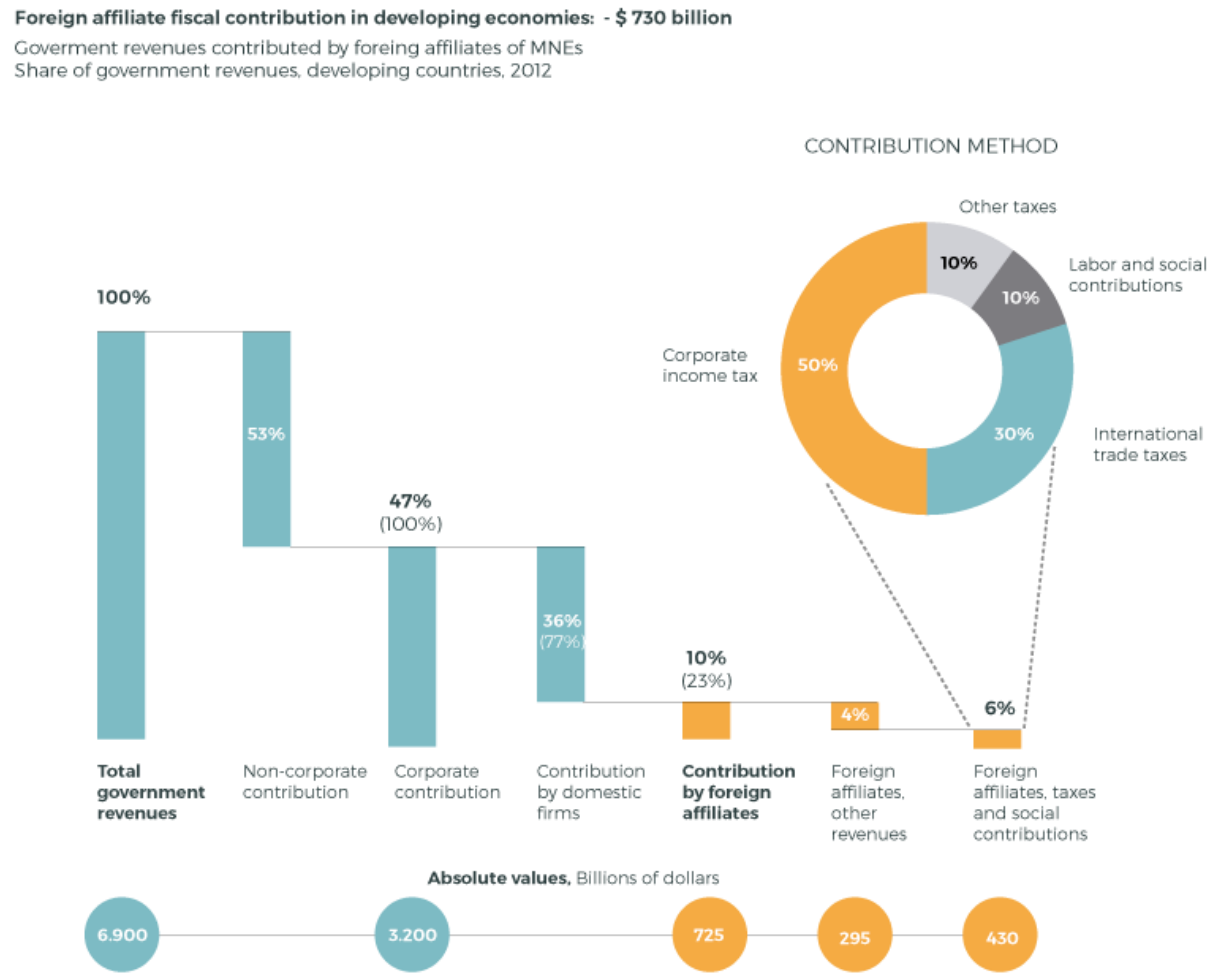

\footnotetext{
66 Toaze, Deborah. Tax Sparing: Good Intentions, Unintended Results. Canadian Tax Journal, Vol 49, 2001.

${ }^{67}$ Ronald B. Davies. Tax Treaties and Foreign Direct Investment: Potential versus Performance. International Tax and Public Finance. Vol 11, 2004.

${ }^{68}$ UNCTAD, World Investment Report, 2015. p. 185.
} 
According to the 2014 UNCTAD World Investment Report on Substantial Development Goals (SDG): “[t]axation is also an important policy tool to correct market failures in respect of the SDG impact of investment". The burden is placed on developing countries to broaden their tax base, improve tax collection capabilities and combat tax avoidance. ${ }^{69}$ Although UNCTAD stresses the importance of ensuring policy coherence and the interaction of policies (including investment, trade, tax, amongst others),$^{70}$ it is not clear how this is to be achieved in practice. For the time being, the concerns of both developed and developing countries relate to the erosion of the tax base due to tax avoidance and tax evasion. The BEPS Report focuses its efforts on those matters, and in particular, on profit shifting. The role of offshore beneficial jurisdictions is of paramount importance, as the image below reveals. ${ }^{71}$

Some $30 \%$ of FDI is routed through offshore hubs
Non-OFC inward investment stocks, by type of investor
Vertical view of the Offshore Investment Matrix (Per cent)

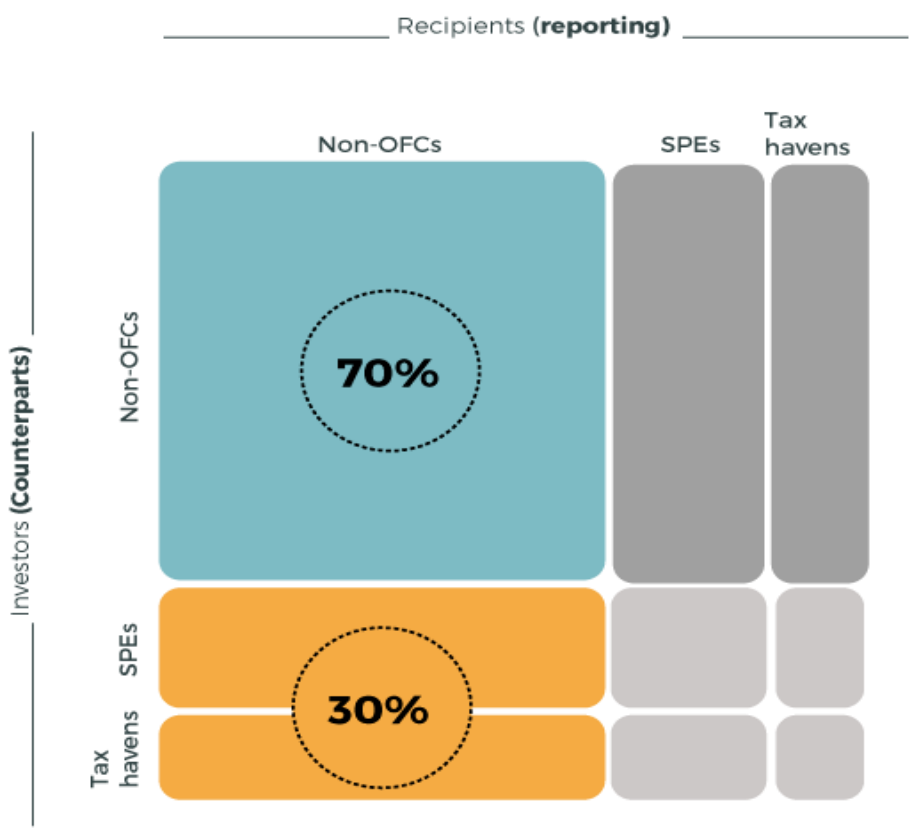

\footnotetext{
${ }^{69}$ UNCTAD, World Investment Report, 2014. p. 180.

${ }^{70} \mathrm{Ibid}, 70$.

${ }^{71}$ UNCTAD, World Investment Report, 2015. p. 190.
} 
The exposure of developed and developing countries to this phenomena seems to be similar: ${ }^{72}$

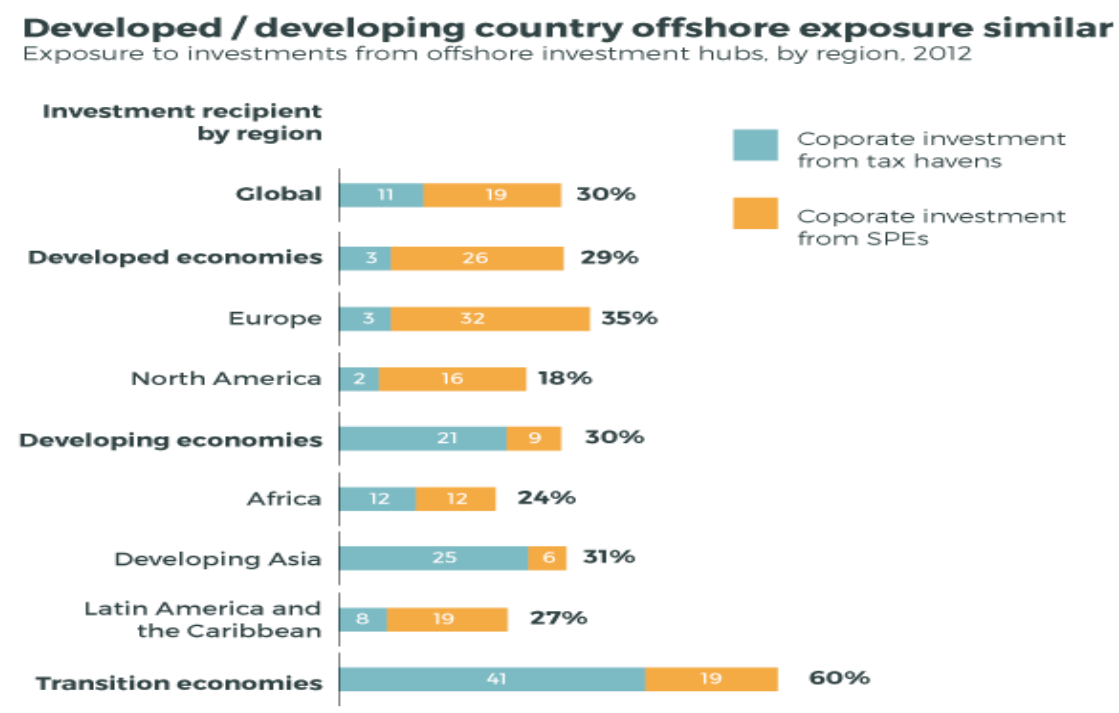

Related to this matter, the European Commission (EC) published a plan to strengthen the fight against tax fraud and international tax evasion (COM (2012) 722/2 ${ }^{73}$ and C (2012) 8806 ${ }^{74}$ ) on 6 December 2012 which, amongst other measures, included recommendations to the EU Member States to limit aggressive planning through clauses in both domestic law and DTCs, subjecting the tax treatment of income or of expenses in other states in order to ensure taxation in one or both Member States. As was stated by the EC, this plan also represents a general contribution to the wider international debate on taxation and its aim is to assist the G20 and the G8 in its on-going work in this field. ${ }^{75}$ It also recommended the adoption of a general anti-abuse rule so as to allow tax authorities to pursue artificial transactions which lack economic substance. On 20 June 2016, the Council of the European Union adopted

\footnotetext{
${ }^{72}$ UNCTAD, World Investment Report, 2015. p. 201.

${ }^{73}$ European Commission. COM (2012) 722/2. Communication from the Commission to the European Parliament and the Council - An Action Plan to strengthen the fight against tax fraud and tax evasion. Available at: https://ec.europa.eu/taxation_customs/sites/taxation/files/resources/documents/taxation/tax_fraud_evasion/co m_2012_722_en.pdf

${ }^{74}$ European Commission. C (2012) 8806. Commission Recommendation. Available at: https://ec.europa.eu/taxation_customs/sites/taxation/files/docs/body/c_2012_8806_en.pdf 75 Ibid, 74.
} 
Directive (EU) 2016/1164 ${ }^{76}$ establishing rules against tax avoidance practices that directly affect the functioning of the internal market. The Directive contains five legally-binding antiabuse measures which all Member States should apply against common forms of aggressive tax planning.

The BEPS Report deals with a number of actions that intend to combat profit shifting that is mainly caused by aggressive tax planning in the channelling of income to low tax jurisdictions. A number of proposed actions relate to passive investments income, due to its very nature (e.g., Actions $3^{77}-4^{78}-6^{79}$ ). Although BEPS does not intend to deal with issues relating to the allocation of income, actions related to income from passive investments ensure that current issues in relation to the allocation of such income become salient.

As stated, although developed and developing countries are involved, ${ }^{80}$ their degree of involvement is based on different reasons. All countries believe that by combating profit shifting, the erosion of tax bases can be prevented. This, however, may not prove to be true. The reasons are the same as those discussed in this research regarding developing countries and DTCs: although a number of actions are needed to improve the coherence of international taxation, the erosion of the tax base will continue, in particular for developing countries, on the basis that they are source countries, and because the application of the rules focuses on the protection of countries of residence of the investors, creditors, or technology/patent

\footnotetext{
${ }^{76}$ Council Directive (EU) 2016/1164, 12 July 2016. Laying down rules against tax avoidance practices that directly affect the functioning of the internal market. Available at: http://eur-lex.europa.eu/legal-content/EN/TXT/?uri=celex:32016L1164

${ }_{77}$ OECD BEPS Project: Final Report Action 3: Designing Effective Controlled Foreign Company Rules, 2015. Available at: http://www.oecd.org/tax/designing-effective-controlled-foreign-company-rules-action-3-2015-final-report9789264241152-en.htm

${ }^{78}$ OECD BEPS Project: Final Report Action 4: Limiting Base Erosion Involving Interest Deductions and Other Financial Payments, 2015. Available at: http://www.oecd.org/tax/limiting-base-erosion-involving-interest-deductions-and-other-financial-paymentsaction-4-2015-final-report-9789264241176-en.htm

${ }^{79}$ OECD BEPS Project: Final Report Action 6: Preventing the Granting of Treaty Benefits in Inappropriate Circumstances, 2015. Available at: http://www.oecd.org/tax/preventing-the-granting-of-treaty-benefits-in-inappropriate-circumstances-action-62015-final-report-9789264241695-en.htm

${ }^{80}$ OECD BEPS Project: Developing Countries and BEPS, 2016. Available at: http://www.oecd.org/tax/developing-countries-and-beps.htm
} 
developers. This is, on the one hand, due to the unresolved conflict between source and residence countries, and on the other, by not considering the attraction of foreign investment as a goal of DTCs and international tax policies.

\subsubsection{DTC EFFECTS ON FOREIGN INVESTMENT}

DTCs, as a determinant factor in increasing foreign investment and achieving development, were recognized by the UN in 1967 through the United Nations Economic and Social Council (ECOSOC) by stating that it was: “(...) confident that tax treaties between developed and developing countries can serve to promote the flow of investment useful to the economic development of the latter, especially if the treaties provide favourable tax treatment to such investments on the part of the countries of origin, both by outright tax relief and by measures which would ensure to them the full benefit of any tax incentive allowed by the country of investment". ${ }^{81}$ The above was ratified by the most recent version of the Manual for the Negotiation of Bilateral Tax Treaties of the UN. ${ }^{82}$

The increase in investments between treaty partners is, in theory, and at least for developing countries, an economic starting point in the decision to sign a DTC. ${ }^{83} 84$ The benefits that are offered to investors from one treaty partner should, in theory, be compensated by the same benefits given to that country's own investors by the other treaty partner. ${ }^{85} 86$ The system to

\footnotetext{
${ }^{81}$ United Nations, Economic and Social Council, Resolution 1273 (XLIII), E/4429, 1967.

82 United Nations, Department of Economic and Social Affairs, Division for Public Administration and Development Management. Manual for the Negotiation of Bilateral Tax Treaties between Developed and Developing Countries, 2019.

${ }^{83}$ Baggerman-Noudari, Khadija; and Offermanns, René. Foreign Direct Investment in Developing Countries: Some Tax Considerations and Other Related Legal Matters. IBFD, Bulletin for International Taxation, 2016.

${ }^{84}$ United Nations, Department of Economic and Social Affairs, Model Double Taxation Convention between Developed and Developing Countries, 2017. Introduction, Origin of the United Nations Model Convention: Paragraph 4: "The desirability of promoting greater inflows of foreign investment to developing countries on conditions which are politically acceptable as well as economically and socially beneficial has been frequently affirmed in resolutions of the General Assembly and the Economic and Social Council of the United Nations and the United Nations Conference on Trade and Development."

${ }^{85}$ Barthel, Fabian; Busse, Matthias; and Neumayer, Eric. The Impact of Double Taxation Treaties on Foreign Direct Investment: Evidence from large dyadic panel data, Contemporary Economic Policy, Vol 28, 2010.

${ }^{86}$ Easson, Alex. Do We Still Need Tax Treaties, IBFD, Bulletin for International Taxation, Vol 54, N¹2, 2000.
} 
limit the source country's taxation rights in relation to passive investment income and give residual taxing rights to the residence country mostly have a neutral impact in treaties between two countries that are at roughly the same level of economic and industrial development, due to the existence of similar investment and income flows so that neither country receives a grossly disproportionate share of the tax revenue. ${ }^{87}$ Moreover, as long as the capital flows are more or less reciprocal, DTCs can reduce the administrative burden of imposing withholding taxes, and the net revenue will be more or less the same. ${ }^{88}$ In that case, the OECD MTC approach of sharing taxing rights in relation to passive investment income, by following the reciprocity principle, regarding the imposition of withholding taxes - only regarding interest and dividends - can be justified due to the neutrality that such an MTC creates, if it is followed by countries with similar investment flows. The above leads to the result that the benefits of DTCs - the elimination of juridical double taxation and the reduction of administrative complexities - can promote the increase of foreign investments in a more or less reciprocal way.

Whilst the above is interesting for countries with similar levels of investment flows, it is certainly not when there are dissimilar investment flows. ${ }^{89}$ The treatment of passive investment income in the UN MTC mostly follows the approach that was designed by the OECD for DTCs between developed countries. When there are no similar investment flows, the host / source country - in a DTC that follows the UN MTC approach, this is typically the developing country - is forced to limit its taxing rights regarding passive investment income. If it is not signed in a context in which there is reciprocal passive investment income generated / sourced in the developed country, which can be taxed by the developing country as a residence country, the result is an undesired shift of tax revenue from the developing to the developed country. When the relationship is similar in terms of investments - usually in DTCs between developed countries - the source country does not incur tax costs, because the tax revenue they lose on inward foreign investment flows is offset by the tax revenue they

\footnotetext{
${ }^{87}$ Barthel, Fabian; Busse, Matthias; and Neumayer, Eric. The Impact of Double Taxation Treaties on Foreign Direct Investment: Evidence from large dyadic panel data, Contemporary Economic Policy, Vol 28, 2010.

${ }^{88}$ Avi-Yonah, Reuven S. Double Tax Treaties: An Introduction, University of Michigan Law School, 2007. Available at : http://papers.ssrn.com/sol3/papers.cfm?abstract_id=1048441.

${ }^{89}$ Bloningen, Bruce A. A Review of the Empirical Literature on FDI Determinants. Atlantic Economic Journal, Vol 33, 2005.
} 
gain from outward foreign investment flows. ${ }^{90}$ This statement does not apply in the context of a DTC that has been concluded between countries with dissimilar investments flows.

The effort of renouncing the ability to collect revenues in relation to passive investment income - income that will be taxed by the residence country recognizing only a credit for the limited withholding tax at source - does not seem to be worthwhile if the DTC is not able to positively attract foreign investment. The cost is only granting foreign investors legal certainty and stability. ${ }^{91}$

The traditional belief of developing countries that a DTC with a developed country will increase foreign investment has not been consistently proven by scientific research. The only empirical evidence is the fact that as the size of asymmetry of foreign investments grows, the scope for cooperation decreases, and negotiated withholding taxes tend to be higher as a result, ${ }^{92}$ thereby distorting the analysis of which country the economic activity that gives rise to the income belongs to. The above statement regarding the increase in withholding taxes is seen by developing countries as a conventional solution to the problem of the allocation of taxing rights and development. Withholding taxes distort the economic logic of the agreement, and they do not tackle the real problem, which is the voluntary limitation of developing countries' legitimate rights to tax passive investment income in pursuance of a superior goal, namely development.

Richard Chisik and Ronald Davies' work in this field ${ }^{93}$ is based on data from US and OECD bilateral tax treaties up until 1992. As a consequence, it does not apply to the UN MTC and to the reality of DTCs between developing and developed countries, at least in theory. Nonetheless, what can definitively be concluded from that work is the fact that: "As the size of asymmetry of foreign investments grows, reciprocity principle regarding withholding

\footnotetext{
${ }^{90}$ Baker, Paul L. An Analysis of Double Taxation Treaties and their Effect on Foreign Direct Investment. International Journal of the Economics of Business, Vol 21, 2014.

${ }^{91}$ Davies, Ronald B. Tax Treaties and Foreign Direct Investment: Potential versus Performance. International Tax and Public Finance. Vol. 11, 2004.

${ }^{92}$ Chisik, Richard; and Davies, Ronald B. Asymmetric FDI and tax-treaty bargaining: theory and evidence, Journal of Public Economics, Vol 88, 2004.

${ }^{93} \mathrm{Ibid}, 93$.
} 
taxes over passive investment income does not achieve justice anymore". ${ }^{94}$ This conclusion also holds true in relation to DTCs between developing and developed countries that are based on the UN MTC.

These facts must be taken into consideration by developing countries when agreeing to a DTC with a developed country, especially due to the harmful effects of limiting their taxing rights in relation to passive investment incomes.

The research conducted by Eric Neumayer in 2006 claimed that: "Developing countries with more Double Tax Conventions with major capital exporting developed countries benefit from a higher overall Foreign Direct Investment stock and share of stock and receive more Foreign Direct Investment inflows as well as a higher share of inflows". However, the research stated that such a conclusion was only valid regarding middle-income countries ${ }^{96}$ and not, therefore, to low-income countries. ${ }^{97}$ The above conclusions open a window to an objective conclusion, i.e., that if we have to differentiate between developing countries, then it may be done according to the level of development of the country. In the same vein, it may be an option to opt for an alternative approach, namely not to differentiate according to the level of development of the country, but to focus on the real impact of the investment in the host / source / developing country.

\footnotetext{
94 Ibid, 93.

${ }^{95}$ Neumayer, Eric. Do double taxation treaties increase foreign direct investment to developing countries?. The Journal of Development Studies, Vol 43, 2007.

${ }_{96}$ Ibid., 96. Appendix 1. Middle-income countries (Gross National Income in 2001 more than \$745): Albania, Algeria, Antigua and Barbuda, Argentina, Barbados, Belarus, Belize, Bolivia, Botswana, Brazil, Bulgaria, Cape Verde, Chile, Colombia, Costa Rica, Croatia, Czech Republic , Dominica , Dominican Republic, Ecuador, Egypt , El Salvador, Equatorial Guinea, Estonia, Fiji, Gabon, Georgia, Grenada, Guatemala, Guyana, Hungary, Iran, Jamaica, Jordan, Kazakhstan, Korea (Rep.), Latvia, Lebanon, Lithuania, Macedonia FYR, Malaysia, Mauritius, Mexico, Morocco, Namibia, Panama, Papua New Guinea, Paraguay, Peru, Philippines, Poland, Romania, Russian Federation, Seychelles, Slovak Republic, South Africa, Sri Lanka, St. Kitts and Nevis, St. Lucia, St. Vincent and the Grenadines, Swaziland, Syria, Thailand, Trinidad and Tobago, Tunisia, Turkey, Ukraine, Uruguay, Uzbekistan, and Venezuela.

97 Ibid., 96. Appendix 1. Low-income countries (Gross National Income in 2001 less than or equal to \$745):Angola, Armenia, Azerbaijan, Bangladesh, Benin, Burkina Faso, Burundi, Cambodia, Cameroon, Central African Republic, Chad, China, Comoros, Congo (Dem. Rep.), Congo (Rep.), Côte d'Ivoire, Ethiopia, Gambia, Ghana, Guinea, Guinea-Bissau, Haiti, Honduras, India, Indonesia, Kenya, Kyrgyz Republic, Lesotho, Madagascar, Malawi, Mali, Mauritania, Moldova, Mozambique, Nepal, Nicaragua, Niger, Nigeria, Pakistan, Rwanda, São Tomé and Principe, Senegal, Sierra Leone, Tanzania, Togo, Uganda, Vietnam, Yemen, Zambia, and Zimbabwe.
} 
Notwithstanding how conclusive Neumayer's research seems to be, in the analysis of the allocation of taxing rights in relation to passive investment income in the UN MTC, that conclusion cannot be used as a valid argument for developing countries to justify concluding DTCs with developed countries under the current rules. Firstly, this is so because the research was not based on treaties that only followed the UN MTC ${ }^{98}$ and, secondly, because $96 \%$ of low-income countries that were considered in that research - to which the results do not apply - are members of the $\mathrm{UN},{ }^{99}$ and it is likely that most of them intend to use the UN MTC in the negotiation of a DTC with a developed country.

Furthermore, Paul L. Baker, in his research entitled "An Analysis of Double Taxation Treaties and their Effect on Foreign Direct Investments" 100 claims, by using a segmented data set and matching econometrics, that DTCs have no effect on foreign investment from developed to less developed countries. The reason for this is because developed countries unilaterally provide for relief on double taxation and the prevention of fiscal evasion, regardless of the treaty status of the host country.

Finally, and by way of contrast to the tendency in the literature regarding the small or even negative effect of DTCs on foreign investment, recent research carried out by Arjan Lejour from the Netherlands Bureau for Economic Policy Analysis, entitled "The foreign investment effects of tax treaties", ${ }^{101}$ arrived at a different conclusion. That research concludes that new DTCs increase bilateral FDI by $21 \%$ if the tax treaties include geographic variables. After ten years, the effects are less. The analysis was based on bilateral treaties which specifically dealt with taxes on profits and returned earnings such as dividends, interest income and royalties. Notwithstanding how relevant the conclusions of Arjan Lejour's work are for developed countries, his research and conclusions are unfortunately not applicable for developing countries. Based on data covering all bilateral foreign investment information of reporting OECD countries to all their partner countries, between 1985 and 2011, i.e., 34

\footnotetext{
${ }^{98}$ Ibid, 96 . p. 6.

${ }^{99}$ United Nations, List of UN Member States. Available at: http://www.un.org/es/members/

${ }^{100}$ Baker, Paul L. An Analysis of Double Taxation Treaties and their Effect on Foreign Direct Investment, International Journal of the Economics of Business, Vol 21, 2014.

${ }^{101}$ Lejour, Arjan. The foreign investment effects of tax treaties. CPB Netherlands Bureau for Economic Policy Analysis, 2014.
} 
OECD countries reporting inward and outward stocks of 233 partners countries, it is not possible to apply the conclusions of that research to developing countries.

The actual status of the UN MTC does not provide incentives for foreign investment in any special way. The UN effort has been more related to a discussion on the source-residence distinction, instead of on designing tax rules that aim to incentivize foreign investment in developing countries.

The fact that the UN MTC reinforces source country taxation more than the OECD MTC does not mean that the UN MTC has achieved more fairness in relation to the allocation of taxing rights. It only means the application of a non-economically justified principle that is stated in the UN Manual for Negotiation of Bilateral Tax Treaties as follows: "The United Nations Model Convention represents a compromise between the source principle and the residence principle. However, it gives more weight to the source principle than does the OECD Model Convention (...)". There is no explanation of how "giving more weight" will allow the model to achieve the deserved fairness.

Therefore, when a developing country decides to negotiate a DTC with a developed country, the most important factors to be analysed are the potential loss of tax revenue versus the increase in foreign investment. This is because the realities of a developing country do not fit into a system that is based on the assumption that there are similar investment flows between treaty partners.

The OECD MTC solves this problem on the basis of the expected reciprocity of investment flows. The policy is based on the premise that taxing rights between the two treaty partners will be balanced. According to this premise, DTCs between two developed countries are expected to have little revenue effect on either country. ${ }^{102}$ The above cannot be said regarding investments flows between developing and developed countries that are, in essence, highly

${ }^{102}$ Christians, Allison. Tax Treaties for Investment and Aid to Sub-Saharan Africa: A Case Study in The Effect of Treaties on Foreign Direct Investment: Bilateral Investment Treaties, Double Taxation Treaties, and Investment Flows. eds. Karl P. Sauvant and Lisa E. Sachs. Oxford University Press, 2009. 
asymmetric. Entering into a DTC under those conditions often leads to a loss of tax revenue for the developing country. ${ }^{103}$

The OECD MTC approach, and therefore that of the UN MTC, is based on the assumption that a reciprocal reduction of withholding tax plus a tax credit will increase fairness and avoid juridical double taxation, while promoting an increase in foreign investment. ${ }^{104}$ This statement is definitely not applicable for DTCs between developing and developed countries.

If DTCs do not increase foreign investment from developed to developing countries, ${ }^{105}$ the traditional fear of developing country negotiators, that is the necessity to conclude DTCs in order to attract foreign investment, loses sense. This misunderstanding surely comes from the fact that the Manual for the Negotiation of Bilateral Tax Treaties between Developed and Developing Countries ${ }^{106}$ states that the encouragement of economic growth by addressing international double taxation and other barriers to cross-border trade and investment is one of the objectives of the UN MTC. The fifth paragraph of the introduction to the 2017 UN MTC stresses that " (...) the growth of investment flows between countries depends to a large extent on prevailing investment climate. The prevention or elimination of international double taxation in respect of the same income, the effects of which are harmful to the exchange of goods and services and to the movement of capital and persons, constitutes a significant component of such a climate".

Notwithstanding the statement above, the UN MTC, instead of designing rules to prevent or eliminate double taxation that concomitantly promote the growth of investment, decided to follow the OECD MTC in this regard.

\footnotetext{
${ }^{103}$ Barthel, Fabian; Busse, Matthias; and Neumayer, Eric. The Impact of Double Taxation Treaties on Foreign Direct Investment: Evidence from large dyadic panel data, Contemporary Economic Policy, Vol 28, 2010.

${ }^{104}$ United Nations, Handbook on Selected Issues in Administration of Double Tax Treaties for Developing Countries. Edited by Alexander Trepelkov, Harry Tonino and Dominika Halka. 2013. Available at: https://www.un.org/esa/ffd/wp-content/uploads/2014/08/UN_Handbook_DTT_Admin.pdf

${ }^{105}$ Baker, Paul L. An Analysis of Double Taxation Treaties and their Effect on Foreign Direct Investment. International Journal of the Economics of Business, Vol 21, 2014.

${ }^{106}$ United Nations, Department of Economic and Social Affairs, Division for Public Administration and Development Management. Manual for the Negotiation of Bilateral Tax Treaties between Developed and Developing Countries, 2019. Available at: https://www.un.org/esa/ffd/wp-content/uploads/2019/06/manualbilateral-tax-treaties-update-2019.pdf
} 
Theoretically, the creation of the UN MTC in 1980 was aimed at reinforcing the position of developing countries in DTC negotiations between themselves and with developed countries. In 1968, one year after the UN undertook the work in the field of international taxation, the Ad Hoc Group of Experts on DTCs between Developed and Developing Countries started to formulate guidelines for the negotiation of bilateral DTCs between developed and developing countries, which were adopted over the course of seven meetings that took place until 1977. The guidelines were published in 1979 in the Manual for the Negotiation of Bilateral Tax Treaties between Developed and Developing Countries. ${ }^{107}$ The following year, the UN published the UN MTC. That publication included an MTC and attached commentaries, both of which were prepared and approved by the Group of Experts.

In the 1970s, the problem was even greater than it is today. A large number of disadvantageous DTCs were concluded by newly independent countries as part of the general assumption of rights and obligations from their former colonial powers. ${ }^{108}$

The conclusion of DTC agreements by developing countries with developed countries, as well as DTCs that apply residence taxation of passive investment income without a revenue benefit for them, must be based on the belief that there is something to be gained. Developing countries normally have a weak and vulnerable bargaining position in the negotiation of these kinds of agreements and developed countries refuse to make concessions during the negotiations. Developing countries are particularly vulnerable when they are recipients of indispensable capital and technical assistance from developed countries with which DTCs have been or are to be negotiated. In conclusion, it seems that there is a belief among developing countries that tax revenues must be forgone, due to the acceptance of DTCs with a preference for residence taxation. ${ }^{109} 110$

\footnotetext{
${ }^{107}$ Lennard, Michael. The Purpose and Current Status of the United Nations Tax Work. IBFD, Asia-Pacific Tax Bulletin, Vol 14, 2008.

${ }^{108}$ Irish, Charles R. International Double Taxation Agreements and Income Taxation. The International and Comparative Law Quarterly, Vol 23, 1974.

${ }^{109}$ Braun, Julia; and Zagler, Martin. The true art of the tax deal: Evidence on aid flows and bilateral double tax agreements. World Economy, Wiley, Vol 41, 2018.

${ }^{110} \mathrm{Ibid}, 110$.
} 
The Manual for the Negotiation of Tax Treaties between Developed and Developing countries guides and informs developing countries when they are negotiating DTCs with developed countries, considering the tendency that developed countries policies often outweigh those of the developing countries due to their weak position in terms of knowledge, information and bargaining power. For the purposes of this research, this line of argumentation seems to be obsolete. Notwithstanding that there are still some countries for which knowledge and information are lacking and their bargaining position is weak, the majority of developing countries are involved in international commerce, and they understand the effects of double taxation, and have understood those effects for more than three decades.

Whilst developed countries tend to have a big net of DTCs, developing countries have fewer DTCs, thereby leaving the taxation of an international transaction under the scope of the domestic provisions. ${ }^{111} 112$ There are not many differences as a result. Countries, and especially developed countries, have incorporated rules that are analogous to those set out in their MTCs into their domestic tax systems. ${ }^{113}$ In fact, for developing countries the lack of DTCs may actually have a positive impact on their tax revenues. ${ }^{114}$ Instead, developed countries are the ones that, at least in theory, benefit from DTCs signed with developing

111 Byrne, Peter. Los Convenios Internacionales para evitar la doble tributación. Política Fiscal, 1999. Available at: http://www.ifaperu.org/uploads/articles/46_06_CT24_PDB.pdf

112 United Nations, Department of Economic and Social Affairs, Division for Public Administration and Development Management, Manual for the Negotiation of Bilateral Tax Treaties between Developed and Developing Countries, 2003: "Conclusion of a treaty between two developed countries is facilitated by their approximately similar levels of development so that the reciprocal flows of trade and investment - and hence the respective gain or loss of revenue to the parties from reducing taxes on those flows - have been relatively equal in magnitude. The presumption of equal reciprocal advantages is not valid when the negotiating parties are at vastly different stages of economic development. Consequently, developing countries have, generally speaking, been reluctant to entered into tax treaties unless they can reasonably assume that the treaties will ensure that those detriments are likely to be offset by benefit flowing from the treaty."

${ }^{113}$ Watson, John. Multinational And The Great Tax Debate. Tolley \& Lexis RPSL Tax, 2013. Available at: https://www.taxjournal.com/docs/article-files/multinationals-and-the-great-taxdebate.pdf?sfvrsn=29996e20_2

${ }^{114}$ Serrani, Esteban; with the collaboration of Falco, Adrian. Acuerdos para Evitar la Doble Tributación en América Latina. Análisis de los vínculos entre los impuestos, el comercio y las finanzas responsables. Fundación SES Buenos Aires Red Latindadd 2013. p. 83. Available at:

http://blog.cedla.org/grupopoliticafiscal/wp-content/uploads/2013/09/libroAEDT-castellano.pdf 
countries by receiving a share of the tax revenue attributable to foreign source income. Furthermore, almost all countries have unilateral rules in place to avoid double taxation, either through the exemption of foreign source income or by granting a foreign tax credit or providing a deduction for foreign taxes paid abroad.

In a scenario where there is no DTC in force, the domestic law of capital importing countries - developing countries - will tax passive investment income obtained by non-residents without any conventional limitation. Capital exporter countries - developed countries - will normally tax and eliminate double taxation under domestic laws. This does not mean a higher tax burden to the investor than that which it would face in a scenario with a DTC that follows the current UN MTC. Since the adoption of credit system, which was recommended by the UN MTC for the elimination of double taxation in relation to passive investment income, this is part of a shared system of taxation where not only the residence country, but also the source country, has a right to tax. Ultimately, unless in the case of a participation exemption (which in practice is the approach followed by the majority of developed countries regarding dividend income derived from business investments/FDI), with or without a DTC in force, passive investment income will be taxed at the rate imposed by the residence country, or higher, if there is an excess of credit.

Until now, the best bargaining position of developed countries in treaty negotiations with developing countries has been related with a matter of knowledge and information. The bargaining position of developing countries has been underestimated as a result.

The weakness of developing countries in this field leaves these countries in a position in which they must agree, if it is possible, to the terms of the UN MTC as it is currently designed. In other words, the actual UN MTC has become the lesser of two evils, upon which to base a DTC between a developing and a developed country, even though there is no necessity to agree to such terms due to the lack of incentives for investors to invest in the host / source country and the known harmful effect of shift of tax revenue from the host / source to the home / resident country. 
The literature has considered the UN MTC to be an excellent representation of the intention to re-balance the allocation of taxing rights regarding the taxation of passive investment income, ${ }^{115}$ without considering that by distorting the application of the economic allegiance theory, the only real consequence has been the limitation of the discussion about fairness regarding the taxation of passive investment income to the rate of withholding tax to be charged at source. Such an approach, no doubt created by the decision to follow the OECD MTC and adjust some features and accordingly reinforce taxation at source, has left behind what should really matter for developing countries when concluding a DTC with a developed country. Those adjustments can solve some unjustified positions of the OECD regarding the taxation of passive investment income, but they do not achieve fairness regarding the benefits that a DTC must bring to the signatories.

The UN Guidelines ${ }^{116}$ formed the basis of the 1980 UN MTC. Therefore, the sources used in the creation of the guidelines indirectly influenced the creation of the MTC. The Group of Experts decided to use the OECD MTC as the main source, with the aim of taking advantage of the technical expertise that was embodied in that convention and from its commentaries. Moreover, the UN argued in favour of using this source for reasons of practical convenience, which stemmed from the fact that the convention was being used by OECD member countries in the negotiation of tax treaties, not only with each other but also with developing countries. ${ }^{117}$ The above argument is, however, slightly worrisome. The argument that the OECD MTC was to be used because it was used in the negotiations between developed and developing countries is meaningless, when the aim is to develop an MTC without the mismatches that the OECD MTC has when it is applied for agreements between a developing

\footnotetext{
${ }^{115}$ See: Moreno Uribe, Heriberto; and Arce Vargas, Jorge. Importancia de establecer un acuerdo para evitar la Doble Tributación México-España. Mesa Estrategia Empresarial. V Encuentro estatal de investigación en las ciencias económico administrativas y primer encuentro de integración y articulación de la investigación. Universidad Autonoma del Estado de Hidalgo, 2010; Daurer, Veronika. Tax Treaties and Developing Countries. Intertax, Vol 42, 2014; Dornelles F, The Relevance of Double Taxation Treaties for Developing Countries. Bulletin for International Taxation, Vol 43, 1989; and Qureshi, Asif. Tax Treaty Needs of Developing Countries, in UN Draft Model Taxation Convention. IFA Congress Seminar Series 31, Vol. 4, Wolters Kluwer Law, 1979.

${ }^{116}$ United Nations, Department of Economic and Social Affairs, Division for Public Administration and Development Management. Manual for the Negotiation of Bilateral Tax Treaties between Developed and Developing Countries, 2019. Available at: https://www.un.org/esa/ffd/wp-content/uploads/2019/06/manualbilateral-tax-treaties-update-2019.pdf

${ }^{117}$ United Nations, Department of Economic and Social Affairs, Model Double Taxation Convention between Developed and Developing Countries, 2017. Introduction.
} 
and a developed country. It seems that the aim was to consider the OECD MTC to be adequate to be used by developed countries when negotiating a treaty with a developing country, instead of building an exclusive and fair MTC that could be followed by developing countries when negotiating treaties with developed countries.

Notwithstanding that the introduction to the UN MTC states that: "(...) it was fully understood that there was no presumption of correctness to be accorded to the OECD Model Convention, and that the decisions of the Group were in no way required to be governed by the OECD text", the result is a similar approach to the OECD MTC. The UN MTC was created using the OECD MTC as the main reference text, ${ }^{118}$ with the consequence that the criteria regarding taxation of passive investment income were also included in the UN MTC.

Since no specific target withholding rates were established in the UN MTC, the approach regarding passive investment income simply relies on the expectation that DTCs based on the UN MTC would include a positive withholding rate on royalties and that the withholding rates on dividends and interest would exceed the rates recommended in the OECD MTC. ${ }^{119}$

\subsubsection{SOURCE AND RESIDENCE PRINCIPLES - INTERNATIONAL TAX LAW}

The principles of source and residence are the two main principles that underpin the design of any tax system. For countries, the jurisdiction to impose taxes is an expression of sovereignty that is normally based on the application of one, or a combination of both principles. This normally results in the decision of "limited and unlimited tax liabilities", ${ }^{120}$

\footnotetext{
118 Ibid, 118.

119 McIntyre, Michael J. Developing Countries and International Cooperation on Income Tax Matters: An Historical Review, 2015. Adapted and Updated from Appendix B of Richard M. Bird, William F. Fox, and Michael J. McIntyre, Tax Policy for Developing and Transitional Countries. Unpublished manuscript, 2003. Available at: https://docplayer.net/17186435-Developing-countries-and-international-cooperation-on-income-tax-mattersan-historical-review.html

${ }^{120}$ Schreiber, Ulrich. International Company Taxation: An Introduction to the Legal and Economic Principles. Springer Texts in Business and Economics, 2013. p.13.
} 
i.e. an intentional extension of the jurisdiction to tax by taxing the foreign income of residents (worldwide income taxation) and / or the source income of non-residents.

DTCs serve to resolve the conflicts generated by the superposition of the principles of source and residence at the domestic level. Although DTCs also follow the principles of source and residence, it adds another dimension to this equation. Taxing rights are allocated to one of the contracting states, either the source country or the residence country, or to both contracting states. Regarding passive investment income, DTCs tend to limit the source country's rights to tax only up to a certain threshold, thereby allowing unlimited taxation to the residence country after a deduction in the form of a credit of the tax that has been paid abroad.

In both the UN MTC and the OECD MTC, the allocation of taxing rights results from the application of the economic classification and assignment approach, ${ }^{121}$ in which the classification is made according to a one-sided interpretation of where the primary economic activity that gives rise to the income belongs - economic allegiance. This results in the existence of differences between both MTCs regarding the allocation of taxing rights. If that methodology is neutrally applied, it should probably result in: (1) the allocation of taxing rights in relation to active income to the source country, and (2) the allocation of taxing rights in relation to passive income to the residence country.

The UN MTC's treatment of passive investment income overrides that principle by trying to increase source countries' rights to tax.

In many countries, DTCs prevail over domestic law. This can be the result of the application of a constitutional rule stating such precedence - formal integration - or the application of the Vienna Convention on the Law of Treaties which states that a party may not invoke the provisions of its internal law as justification for its failure to perform a treaty, ${ }^{122}$ as well as

\footnotetext{
${ }^{121}$ Concept defined further in this study. See: 1.2.4

122 Vienna Convention on the Law of Treaties, 1969. Article 27. Available at: https://reaties.un.org/doc/publication/unts/volume\%201155/volume-1155-i-18232-english.pdf
} 
the international principle of "pacta sunt servanda"123 in order to avoid overriding a treaty obligation. $^{124}$

DTCs do not interfere with a country's sovereignty whether or not to choose to tax, or to tax by considering either the source or the residence principle of taxation as the basis for tax jurisdiction. DTCs only re-allocate taxing rights between treaty partners when solving problems of juridical double taxation by applying those principles in a different context. The re-allocation of taxing rights between a developing and a developed country, which is usually achieved unilaterally by domestic legislation without affecting the source country's rights to tax, must be seen, according to this research, as an agreement that is caused by a superior goal.

In DTCs, international equity should be measured by considering much more than the direct division of the right to tax between two countries. It must be the result of a global allocation of actual and expected revenue and benefits, which requires much more than the simple increase of taxation at source of passive investment income. By considering the increase of foreign investment, i.e. access to foreign resources, as one of the goals of a DTC, more development and wealth will be enjoyed by the host / source developing country.

Specifically, regarding passive investment income, the domestic law of the host / source developing country normally applies source taxation, taxing the source income of residents and non-residents, while DTCs reduce source countries' rights to tax and allocate the taxing rights to the home / residence country. As a consequence, the home / residence country retains its right to tax passive income when signing a DTC with a developing country. ${ }^{125}$ Overall, the allocation of taxing rights to the source country is very limited in the current DTC structure. Such an unbalanced situation should not be problematic if comparable benefits

\footnotetext{
${ }^{123}$ Vienna Convention on the Law of Treaties, 1969. Article 26. Available at: https://treaties.un.org/doc/publication/unts/volume\%201155/volume-1155-i-18232-english.pdf

${ }^{124}$ Thuronyi, Victor. Comparative Tax Law. Kluwer Law International, 2003.

${ }^{125}$ This statement is not applicable to the case of DTCs that depart from what the UN Model states by using the participation exemption system as the method to eliminate double taxation regarding dividends income. The statement is applicable in the case of DTCs that follow the UN Model regarding taxation of dividends. It is also applicable in all cases regarding taxation of interest and royalties.
} 
arise as a result of the accession to a DTC. Since that is not the case, such an unbalance has not been really addressed, at least not in a satisfactory manner. The global movement towards tax transparency ${ }^{126}$ is not really focused on fairness or equity and the situation of countries that are importers of capital and technology is simply disregarded, left to its own devices, as was the case in the Mexico MTC.

Reuven S. Avi-Yonah justified the source / residence duality in his publication "The Structure of International Taxation: A Proposal for Simplification", ${ }^{127}$ arguing that, when there is no DTC in force, the source country / host country has no assurance that the income will in fact be taxed by the residence country and therefore it allocates to itself the taxes that should otherwise be paid to the residence country. This is, however, disputable because in the absence of a DTC, the host / source country will most likely tax on the basis of the economic link between the income and the jurisdiction, and not because of the risk of double non-taxation. Source countries levy taxes on passive investment income because they consider that the source of the income is there - linked to their territories. The problem is not the avoidance of double non-taxation, i.e. that the income will not be taxed by the resident country either. Under current MTCs, the above situation is perceived more as an agreement with developed / residence countries whereby host / source developing countries completely or partially relinquish the imposition of taxes on passive investment income - amongst others - to which they have legitimate rights to tax. Notwithstanding the above, as Reuven S. AviYonah also points out, it is clear that a source / host country has fewer taxing rights over passive investment income when there is a DTC in force.

The innovation in the allocation of taxing rights approach regarding passive investment income become a reality in the 1963 OECD MTC, followed by the UN MTC and by the OECD MTC, by maintaining the approach of granting most taxing rights to the residence country, leaving only limited rights to tax to the host / source country in the case of dividends and interests in the OECD MTC, and in the case of dividends, interest and royalties in the UN MTC. That change has always been seen as an improvement regarding host / source

\footnotetext{
${ }^{126}$ OECD BEPS Project.

127 Avi-Yonah, Reuven S. The structure of international taxation: A proposal for simplification, Texas Law Review, Vol. 74, 1996.
} 
countries' rights to tax, especially when compared to the rights to tax that were granted by the LN MTC. However, in doing so, the UN MTC fixed a negotiation line between developing and developed countries, a limit that, according to this research, has affected the evolution of the UN policy regarding the design of a fair MTC between developing and developed countries. The reason for this is simple. The sharing of taxing rights between the host / source and the home / residence country - passive investments income treatment in the UN Model - as well as a credit system to eliminate juridical double taxation consequently neutralizes the effects of source taxation in relation to foreign investments, leaving behind an analysis of the potential benefits of those investments. Since the adoption of the innovative OECD approach to sharing taxing rights, the increase or decrease of source taxation of passive investment income no longer positively or negatively affects a foreign investor's tax burden.

As has already been remarked, and due to the evolution in practice, i.e. participation exemption, the same cannot be said regarding dividends that are derived from business investment / FDI. Since most developed countries have started applying the participation exemption system, with the result that the unilateral reduction of source taxation over those dividends becomes a real incentive to foreign investors.

Unilateral methods regarding interest and royalties have not evolved accordingly. Taxation at source is justified by the benefit theory - the benefit that the host / source developing country implies for the lenders and technology providers, and by the benefits that debt capital and technology provide to developing countries. The actual allocation of taxing rights approach stays there and does not incentivize the access to foreign debt capital and the transfer of technology from developed to developing countries. Both resources - debt capital and technology - assist wealth creation in host / source developing countries, and in turn increase employment and tax revenues, and hence, development. 


\subsubsection{ECONOMIC AND JURIDICAL DOUBLE TAXATION}

Double taxation is one of the barriers that developed countries need to eliminate in order to achieve fruitful trade and investment with developing countries. ${ }^{128}$ According to the OECD, the harmful effects of double taxation on cross-border trade and investment are so well known that it is necessary to stress the importance of removing the obstacles that double taxation engenders for the development of economic relations between countries. ${ }^{129}$ When two developed countries feel the need to eliminate barriers so as to increase trade and investment, DTCs become the optimum tool in that pursuit. Due to the approximate balance in the reciprocity of investment flows and, therefore, rights to tax, DTCs do not force an unreciprocal limitation on one of the two contracting states. The OECD MTC achieves this by improving the market conditions so as to facilitate and increase the amount of trade and investment between the two contracting states.

Since international law places few limits on the sovereign power of countries to tax, the same event / income may be taxed in two or more countries. Therefore, the combination of the above situation, alongside the increase in the volume of international trade and investment during the last century, has resulted in an increase of international juridical double taxation, which is defined as: "The imposition of comparable taxes in two - or more - States on the same taxpayer in respect of the same subject matter for identical periods". ${ }^{130}$ That increase naturally gave rise to an increase in economic double taxation, which could be understood as as: "The imposition of comparable taxes in two - or more - States on different taxpayers in respect of the same subject matter for identical periods". The latter only occurs regarding dividend income. The income arising from interest and royalties are deductible expenses at source; dividends, however, are not.

\footnotetext{
${ }^{128}$ See: United Nations, Department of Economic and Social Affairs, Division for Public Administration and Development Management, Manual for the Negotiation of Bilateral Tax Treaties between Developed and Developing Countries, 2019.; United Nations, Department of Economic and Social Affairs, Model Double Taxation Convention between Developed and Developing Countries, 2017.; OECD, Model Tax Convention on Income and Capital, 2017.

${ }^{129}$ OECD, Model Tax Convention on Income and Capital, 2017. Introduction.

${ }^{130}$ OECD, Model Tax Convention on Income and Capital, 2017. Introduction.
} 
Graetz and O'Hear, in their work on “The Original Intent of U.S. International Taxation”, ${ }^{131}$ described the basic dilemma of international taxation that each country faces as follows: "Despite the seismic changes in the world economy that have occurred in the last seven decades, the fundamental dilemma of international taxation that confronted Thomas Sewall Adams, his Treasury colleagues, and the Congress in the infancy of the income tax remains essentially unchanged. When income is earned in one country by a citizen or resident of another country, both the country where income is earned -the source country-and the country where the investor or earner resides -the residence country- have legitimate claims to tax the income. The basic task of international tax rules is to resolve the competing claims of residence and source nations in order to avoid the double taxation that results when both fully exercise their taxing power".

DTCs only focus their efforts on the elimination of juridical double taxation. When the UN MTC was designed, the elimination of juridical double taxation was, with minor exceptions, a task exclusively reserved to DTCs. The situation is different today, however, due to the positive evolution of domestic legislation through the promulgation of legislation to eliminate juridical and even economic double taxation. ${ }^{132}$

Juridical double taxation ${ }^{133}$ may occur for any of the following reasons:

(1) Two taxing jurisdictions adopt different, and therefore overlapping, criteria for determining liability to be taxed on worldwide income - typically in relation to residence status - such as, in the case of corporations, the discrepancy between the place of incorporation and the place of effective management. For example, a corporation may be treated by country A as a resident because it is incorporated there, whereas country B may treat that corporation as its resident because it is managed there.

\footnotetext{
${ }^{131}$ Graetz, Michael J.; and O'Hear, Michael M. The 'Original Intent' of U.S. International Taxation. Duke Law Journal, Vol 46, 1997.

${ }^{132}$ Olivier, Lynette; and Honiball, Michael. International Tax: A South African Perspective, p. 6, $5^{\text {th }}$ ed., 2011.

${ }^{133}$ Vogel, Klaus. Klaus Vogel on Double Taxation Conventions, $3^{\text {rd }}$ ed., 1997.
} 
(2) Two taxing jurisdictions apply different, and therefore overlapping, jurisdictional principles (source or residence) according to which the income or the capital in question can be taxed. For example, imagine that country A and country B tax income, both at a rate of $50 \%$. Imagine that a resident of A derives 100 units of income with source in country B. In this case, that income could first be taxed by B at $50 \%$ - therefore the resident will pay 50 units in taxes at source - and the remaining income of 50 units could be taxed by A at $50 \%$ - paying taxes of 25 units - on the basis of residence jurisdiction. So, the taxpayer would be left with only [100-50-25] $=25$ units, therefore paying an effective tax rate of $75 \%$.

(3) Two taxing jurisdictions invoke the source principle of taxation to tax the same item of income, but how they determine the source of income under domestic law differs. For example, the domestic law of country A may provide that the sales income of a non-resident corporation is taxable in that state, if the sale is made through an office located in that state. In contrast, the law of country B may tax income derived from sales by a non-resident corporation, if the transfer of possession of the goods sold takes place within that state.

(4) In some cases, a country may have a source-residence conflict with one country and a source-source conflict with another country. For example, assume that company $\mathrm{X}$ is a corporation that is resident in country A. It also has an office in country B and makes sales from that office into country C. Under their domestic laws, country A taxes income from those sales under the residence principle, while countries $\mathrm{B}$ and $\mathrm{C}$ tax that income under the source principle. A DTC between country A and country B is likely to solve the residencesource conflict, but it is probably not able to solve the source-source conflict. If country B and country $\mathrm{C}$ also have a double tax convention, however, the source-source conflict may also be solved.

The relief for this kind of double taxation - juridical double taxation - can take a variety of forms. Firstly, when there is an overlap of residence criteria, normally the only way to resolve the conflict will be to apply the rules of the DTC, whereby preference will be given to certain criteria which may or may not reflect the criteria that are used in domestic law. As an example, the UN MTC and the OECD MTC resolve the conflict of the residency of a person 
other than an individual by determining that, the competent authorities of the Contracting States shall endeavour to determine by mutual agreement the Contracting State of which such person shall be deemed to be a resident for the purposes of the Convention, having regard to its place of effective management, the place where it is incorporated or otherwise constituted and any other relevant factors. In the absence of such agreement, such person shall not be entitled to any relief or exemption from tax provided by this Convention except to the extent and in such manner as may be agreed upon by the competent authorities of the Contracting States. 134135

Secondly, and concerning the overlap of jurisdictional principles under which countries tax the income or the capital in question, typically unilateral acts - domestic law - and bilateral acts - DTCs - provide suitable solutions in this regard. Unilateral and bilateral acts can reduce or eliminate double taxation only if the country of home / residence is prepared to bear all the financial costs of granting that relief. That is why the approach in DTCs under the UN MTC and the OECD MTC are so important to home / residence developed countries. $^{136137}$

Thirdly, when there is an overlap of the source criteria, normally the only way to solve the problem is through a DTC between the countries involved. ${ }^{138}{ }^{139}$ Domestic law has evolved in such a way where situations (1) and (3) above are left almost without a solution. This very much resembles what is mentioned in the guidelines published by international institutions, such as the UN and the OECD.

Going back to the origin, it is important to think back to the time when there were no DTCs, where the only way to eliminate double taxation was through domestic legislation,

\footnotetext{
${ }^{134}$ See Article 4 of the United Nations, Model Double Taxation Convention between Developed and Developing Countries, 2017.

${ }^{135}$ See Article 4 of the OECD Model Tax Convention on Income and Capital, 2017.

${ }^{136}$ See Articles 23 A and 23 B of the United Nations Model Double Taxation Convention between Developed and Developing Countries, 2017.

${ }^{137}$ See Articles 23 A and 23 B of the OECD Model Tax Convention on Income and Capital, 2017.

138 See Article 25 of the United Nations Model Double Taxation Convention between Developed and Developing Countries, 2017.

${ }^{139}$ See Article 25 of the OECD Model Tax Convention on Income and Capital, 2017.
} 
specifically named as "unilateral measures". The unilateral measures adopted to prevent double taxation differed amongst countries. Essentially, a taxpayer could obtain relief from juridical double taxation ${ }^{140} 141142$ by three methods:

(1) The exemption method, where the residence country does not tax the foreign source income;

(2) The tax credit method, where the residence country taxes foreign source income, but allows domestic taxes payable in the resident country to be reduced by the foreign taxes paid in the source country; and,

(3) The deduction method, where the resident country taxes foreign source income, but allows the resident to deduct foreign taxes paid on foreign income from their assessable income in the resident country. Unlike the exemption and the credit methods, the deduction method fails to fully eliminate the existence of double taxation.

The juxtaposition or overlapping of source and residence criteria gives, according to international consensus, a primary right to tax to the host / source country due to the direct link between the income and the territory of the country. Consequently, the right of the residence country to tax the foreign income of their residents normally comes with the responsibility to relieve double taxation, meaning that the source principle is of primary importance whereas the residence principle is only residual.

The above statement has been recognized only in relation to active income by countries that are OECD members and which agree that the country of source / host - the nation where the income is generated - enjoys the primary right to tax active income, while the residence country retains, at most, a residual right to tax such income. In the case of passive investment income, the lack of a link between the territory and the income has been the historical reason

\footnotetext{
${ }^{140}$ Vogel, Klaus. Klaus Vogel on Double Taxation Conventions, $3^{\text {rd }}$ ed., 1997.

${ }^{141}$ Avery Jones, John. Avoiding Double Taxation: Credit vs Exemption, The Origins, Bulletin for International Taxation Vol 66, $\mathrm{N}^{\circ} 2,2012$.

${ }^{142}$ Blanluet, Gauthier; and Durand, Philippe J. General Report in Key practical issues to eliminate double taxation of business income. Cahiers de droit fiscal international 96b, International Fiscal Association, 2011.
} 
as to why primary taxing rights have been granted to the residence country and only limited taxing rights to the source country. However, considering that income tax rates have substantially decreased in the last century, very often source / host countries retain an important part of the split revenue, therefore sacrificing fewer rights / less revenue than was historically the case. This approach of granting partial rights regarding dividends and interest to the host / source countries was followed without substantial restrictions by the UN MTC, considering the OECD criteria regarding the re-allocation of taxing rights suitable for a DTC between a developing and a developed country. Furthermore, the UN MTC increased source taxation in relation to passive income by granting source countries rights in relation to royalty income.

Since taxation is expected to be neutral, the question that arises pertains to whether such demands are also economically neutral in an international context. An historical approach to MTCs allows the author to highlight two major incidences that will guide the analysis in this section. The first incidence regards works that were accomplished before the European Organization for Economic Development drafted its models, and before the OECD took over in this ambit. By that time, the MTCs helped to overcome the lack of unilateral measures to avoid juridical double taxation, while the credit method was very much in fashion at that time. The second incidence concerns developments in domestic law: the adoption of the participation exemption method by developed countries in their domestic laws. The impact of taxing dividends at source became enormous as a result. The situation is different for interest and royalties, as well as for DTCs signed by home / resident developed countries that still use the credit method as the system to avoid cross-border juridical double taxation in relation to dividends. When the participation exemption regime applies, it is necessary to analyse if double taxation is effectively eliminated. Corporate taxation (first tier taxation) in the host / developing country plus the second tier taxation of business profits in the form of dividends at source - withholding tax - plus exemption at corporate level, but taxation at the level of the ultimate beneficial owner in the residence country and without any credit does not seem to be an effective approach. The UN must consider not only juridical double taxation but also economic double taxation as a restriction to investment flows. Moreover, an additional harmful element is that this second tier of taxation over business profits in the 
form of dividends is determined on a gross basis, and therefore, it does not allow for the deduction of expenses.

If DTCs do not offer an ideal scenario, it is very important to establish what the domestic law offers if there is no DTC in force. The answer is straightforward: in most cases, juridical double taxation will be eliminated by the state of residence. As consequence of this "status quo", the primary right to tax of the source country is naturally reinforced and the residence country may need to provide relief from the effects of double taxation. This means, in other words, that both the exemption method and the credit method to eliminate juridical double taxation at the domestic level recognize the right to tax of source countries as primary and the one of resident countries only in a residual manner.

Consequently, the main question that developing countries' governments have probably asked themselves during the last decades in relation to the conclusion of DTCs is: if in a market without DTCs, the elimination of double taxation is an international duty mostly assumed by residence countries, and in the relationship between developed and developing countries where in the majority of cases the developing country is the source country, why should developing countries conclude DTCs with developed countries and limit their right to tax passive investment income at source? Notwithstanding the fact that the majority of domestic tax systems in developing countries have the main aim of raising revenue and protecting the domestic tax base, it is essential to understand that in a globalized world, that aim should be tempered by the need for a country to have more trade and international investment that ensures that its economy remains strong.

\subsubsection{DTC ALLOCATION OF TAXING RIGHTS - ECONOMIC THEORIES}

Many countries have found it necessary to supplement their unilateral measures so as to relieve double taxation by entering into a network of DTCs with their principal commercial partners with which their taxpayers are involved in trade or investment. 
When two countries agree on the conclusion of a DTC, they accept an international law obligation: they commit themselves to relinquish, completely or partially, the collection of taxes in specific situations. The convention is subject to the rules of public international law. ${ }^{143}$ A DTC is, by its very definition, a joint act of two contracting states and one of its main objectives is to avoid the juridical double taxation that is caused by the overlapping of jurisdictional principles.

As was indicated before, source and residence principles manifest themselves in a different way in the context of DTCs. For instance, in the following three cases, such principles play a major role: (1) on the subjects eligible for treaty benefits - subjective scope of the treaties. In the UN MTC, the relevant article reads as follows: "This Convention shall apply to persons who are residents of one or both of the Contracting States"; (2) on the allocation of taxing rights to the source or to the residence country; and (3) in the methods used to eliminate double taxation: credit and exemption.

Source and residence principles are of great relevance for developing countries in order for them to agree to fair terms as to what extent they have the right to tax, i.e. until which point should developing countries assume limitations to their sovereignty to tax passive income. No general consensus has been achieved on this point. For some legal scholars, the solution embodied in DTCs - which has remained unchanged since their adoption in the 1920s until now - is that "(...) jurisdiction to tax is assigned to either the source country or the residence country for different kinds of income" 144 and this represents the outcome of bargains in which conflicting tax claims have been traded off against each other on a case-by-case basis. Therefore they are no more than a set of arbitrary rules that were carefully drafted to support a specific compromise.

The supposedly strong source position of the UN MTC, which grants more revenue regarding some specific types of income, has been justified by the UN as an issue of particular

\footnotetext{
${ }^{143}$ Lang, Michael. Introduction to the Law of Double Taxation Conventions, $2^{\text {nd }}$ ed. Linde, 2010.

${ }^{144}$ Graetz, Michael. Taxing international income: inadequate principles, outdated concepts, and unsatisfactory policies. Tax Law Review, Vol 54, 2001.
} 
importance for developing countries, especially in view of their development goals. ${ }^{145}$ Unfortunately, it is not clear if the UN MTC has actually achieved its goals.

As was already stated, the international treaty framework regarding the allocation of taxing rights has been mainly governed by the economic classification and assignment approach, which is applied in order to determine the economic allegiance of the taxpayer with the country. The economic allegiance theory, proposed by George Schanz in 1892, may ensure a fair and equitable distribution of tax revenues between countries in a treaty context. ${ }^{146147}$

Until now, and especially regarding passive investment income, the application of the economic classification and assignment method has been limited to the withholding tax rate that the host / source country can impose. The attraction of foreign investment has not played a major role in this respect. MTCs neither incentivize nor increase (as a consequence) foreign investment, 148149150 easy access to debt, or the transfer of beneficial technology in the host / source developing country.

${ }^{145}$ United Nations, Department of Economic and Social Affairs, Division for Public Administration and Development Management, Manual for the Negotiation of Bilateral Tax Treaties between Developed and Developing Countries, 2019.

146 von Schanz, George. Zur Frage der Steuerpflicht (Regarding Tax Liability), Vol 9, Finanzarchiv, 1892.

${ }^{147}$ Brooks, Kim. Tax Treaty Treatment of Royalty Payments from Low-Income Countries: A Comparison of Canada and Australia's Policies. EJournal of Tax Research, Vol 5, No. 2, 2007. Available at: http://papers.ssrn.com/sol3/papers.cfm?abstract id=1078738

148 Neumayer, Eric. Do double taxation treaties increase foreign direct investment to developing countries? The Journal of Development Studies, Vol 43, 2007: "Blonigen and Davies (2002) in an analysis of bilateral FDI outflows and outbound stocks from OECD countries to other countries over the period 1982 to 1992 find that the existence of DTTs is associated with larger bilateral FDI flows and stocks in ordinary least squares $(O L S)$ estimation. However, when older DTTs, which have often been concluded many years before the start of the study period, are distinguished from newer DTTs, which were concluded during the period of study, then it appears that these newer treaties have no positive effect on FDI in OLS estimation. In fixed-effects estimation, based on the within-variation of the data only such that old treaties concluded before the start of the sample become irrelevant, the effect is even negative. Similarly, Blonigen and Davies (2004) in an analysis of US inbound and outbound FDI over the period 1980 to 1999 find that treaties concluded by the US during this period had no statistically significant effect at best and a negative effect at worst on inbound and outbound FDI stocks.3 Davies (2004) confirms the non-significant and negative findings of both studies and, additionally, finds non-significant results if looking explicitly at treaty renegotiations. Egger et al. (2004) also find a negative effect of newly implemented DTTs in a differences-in-differences analysis of two years prior and two years after treaty conclusion using dyadic FDI data over the period 1985 to 2000".

${ }^{149}$ Lejour, Arjan. The foreign investment effects of tax treaties. CPB Netherlands Bureau for Economic Policy Analysis, 2014.

${ }^{150}$ Baker, Paul L. An Analysis of Double Taxation Treaties and their Effect on Foreign Direct Investment. International Journal of the Economics of Business, Vol 21, 2014. 
In addition to the above, it is important to note that developed countries may potentially increase their revenue expectations to the detriment of source countries' rights - normally developing countries - when signing a DTC that is based on the UN MTC. This is mainly due to two reasons: (1) without a DTC in force, the residence country will normally be forced to eliminate double taxation in relation to passive investment income and the source country will normally tax that income without limitations, and (2) because the UN MTC, instead of creating an incentive for foreign investment in the developing country as a counterpart for the agreed limitation of sovereignty of the source country - developing country - as a consequence of the DTC, mainly follows the OECD MTC approach by restricting source country taxation up to a fixed withholding tax and forces the residence country to grant a credit for the taxes paid at source as the best way to eliminate double taxation. In this context, and regarding passive investment income, by concluding a DTC based on the UN MTC, residence countries - developed countries - increase their taxing rights compared to the taxing rights they would have in a scenario where there is no DTC. As an aftereffect, source countries - developing countries - diminish their taxing rights in relation to those incomes, compared to the rights they would have in a scenario where no DTC has been signed.

DTCs are instrumental in enforcing the residence principle through the allocation of taxing rights among countries, ${ }^{151}$ and they do so by reducing withholding taxes on passive investment income at source. This then results in the undesirable effect of shifting tax revenue from host / source countries - normally developing countries - to home / residence countries - normally developed countries. This can happen in a treaty between a developing and a developed country that has incorrectly followed the OECD MTC, but it nevertheless occurs if both countries decide to follow the UN MTC.

\footnotetext{
${ }^{151}$ Ligthart, Jenny; Vlachaki, Mina; and Voget, Johannes. The Determinants of Double Tax Treaty Formation. Tilburg University, 2011. Available at: http://www.researchgate.net/publication/228431711_The_Determinants_of_Double_Tax_Treaty_Formation
} 


\subsubsection{ECONOMIC ALLIEGIANCE THEORY}

George Schanz proposed the economic allegiance theory in 1892 as a principle to ensure the fair and equitable distribution of tax revenues between countries. ${ }^{152}{ }^{153}$ According to this theory, a country's rights to tax arise when a person is economically related to that country. The economic allegiance to a state can be based on mere consumption or on business or investment criteria. ${ }^{154}$ While in the first scenario, the residence country enjoys the allocation of rights, in the second scenario, the rights are allocated to the source country. If the person is economically linked to his country of residence and to another country due to business activities or income arising therein, Schanz deems the allegiance to the source state to be more important than the link to the country of residence. ${ }^{155} 156$ For Schanz, in this situation, the state of residence to which the taxpayer is connected through consumption should get its share, but it should be less than the share of the source state where the income is produced. His solution was to divide the tax base. Three-quarters of the income in question should be taxed in the state of source and one-quarter should be taxed in the state of residency. ${ }^{157}$

For a good understanding of the economic allegiance concept, an approach to the concepts of political and personal allegiance is required. ${ }^{158}$ Political allegiance is the relationship with the country due to nationality or, in some instances, by some supranational political integration e.g., the European Union. Personal allegiance has its principal manifestation in the concept of effective residency. By differentiating both allegiances, the economic allegiance is the result of relatively intense taxpayer participation, who is neither a national

\footnotetext{
152 von Schanz, George. Zur Frage der Steuerpflicht (Regarding Tax Liability), Vol 9, Finanzarchiv, 1892.

${ }^{153}$ Brooks, Kim. Tax Treaty Treatment of Royalty Payments from Low-Income Countries: A Comparison of Canada and Australia's Policies. EJournal of Tax Research, Vol 5, No. 2, 2007.

${ }^{154}$ Vogel, Klaus. Worldwide vs source taxation of income - A review and re-evaluation of arguments. Intertax Vol 16, 1988.

${ }^{155}$ Pinto, Dale. E-commerce and source-based income taxation. International Bureau for Fiscal Documentation, Doctoral Series Vol 6, 2003.

${ }^{156}$ Vogel, Klaus. Worldwide vs source taxation of income - A review and re-evaluation of arguments. Intertax, Vol 16, 1988.

157 Ibid., 156.

${ }^{158}$ Souza de Man, Fernando. Taxation of Cross-Border Provisions of Services in Double Tax Conventions between Developed and Developing Countries: A Proposal for New Guidelines. PhD Thesis Maastricht University, Faculty of Law, 2013
} 
nor a resident in the country in which the production, movement or consumption of the wealth took place. ${ }^{159}$

Economic allegiance offers countries the proper justification to tax as a way to pay for public costs in exchange for advantageous social, economic or political realities. Hence, this allegiance defines a country's right to tax all those who engage in taxable activities in its territory and, consequently obtain the advantage of being part of the community and usufruct of its goods or public services. ${ }^{160}$ The determinant factor is the involvement or participation of the taxpayer in the economic life of the source country, rather than the benefits that have been received as a result of that participation.

The economic link between the taxpayer and the country was interpreted by the four economists of the League of Nations ${ }^{161}$ as the consequence of the link between the income and the country - achievable through the application of the economic classification and assignment approach - as the suitable approach to apply when international double taxation was discussed at DTC level.

It is not only the involvement or participation, but also the economic relationship between the income and the country, which directly leads to the concepts of passive and active income. Without a clear justification, it can be stated that the UN MTC distorts the analysis by increasing the source countries' rights to tax in relation to passive investment income instead of respecting the fact that neither the taxpayer nor the income, in these cases, is only linked to the source country's economy, and if they are strongly linked to the source country economy, they are, at least in the case of dividends, taxed at first tier by that country as business profits.

\footnotetext{
${ }^{159}$ Rosembuj, Tulio. Personal and Economic Allegiance under the Personal Income Tax and the Corporate Tax in Spain. Intertax, Vol 26, 1998.

${ }^{160} \mathrm{Ibid}, 158$.

${ }^{161}$ League of Nations, Economic and Financial Commission, Professors Bruins, Einaudi, Seligman, and Sir Josiah Stamp. Report on Double Taxation submitted to the Financial Committee, 1923. Available at: http://www.taxtreatieshistory.org/.
} 
Although the Group of Economists of the League of Nations considered the concept of economic allegiance in the international allocation of taxing rights to be appropriate, ${ }^{162}$ the $\mathrm{LN}$, the OECD and the UN used a methodology that led to the application of a concept that was substantially different from Schanz's proposal. While the economists concluded that the best recommendation was to exempt income going abroad, ${ }^{163}$ the Technical Experts ended up including an apportionment approach in the Model. ${ }^{164}$ The above, for the purposes of this research, could be considered as the starting point of the modern approach to international taxation in DTCs regarding the allocation of taxing rights over passive investment income. By comparing the treatment of dividends, interests and royalties in the 1928 Models of the League of Nations, the OECD MTCs that have been drafted since 1963, as well as the UN MTC since 1980, it is possible to realize how this approach has been distorted over time. The emphasis of the UN MTC in its intent to serve as basis for the negotiation of a DTC for a developing country, as one of the DTCs contracting states, does not seem to be as positive as is claimed. This is because, at least for this research, the principle of economic allegiance has been left behind in the determination of the allocation of taxing rights over passive investment income in DTCs between developing and developed countries.

\subsubsection{BENEFIT THEORY}

The benefit theory has played a minor role in the allocation of taxing rights in DTCs, especially when compared to the economic allegiance theory. According to the benefit theory, the power to tax should be related to the benefits received from government expenditures. ${ }^{165}$ For this purpose, it is necessary to establish the distribution of benefits from

\footnotetext{
162 Ibid, 160.

163 Ibid, 160.

${ }^{164}$ League of Nations, Technical Experts to the Economic and Financial Committee. Double Taxation and Tax Evasion. Report and Resolutions submitted by the Technical Experts to the Financial Committee, 1925. Available at: http://www.taxtreatieshistory.org/

${ }^{165}$ Hines, James R. Jr. What is benefit taxation?. Journal of Public Economics, Vol 75, 2000.
} 
public goods. The difficulties of correctly assessing the benefits received by taxpayers makes this theory less strong in comparison to the economic allegiance theory.

The theory serves to justify both source and residence taxation. Source taxation for income derived in one country by non-residents. Residence taxation because of the benefits derived by the residents of a country. Notwithstanding the foregoing, the economic link, from a substantive and realistic perspective, is much more feasible than the residence link. ${ }^{166}$ Given the difficulties that are inherent in implementing this theory, the achievement of fairness is also compromised. Even if it were practicable, since taxes levied by any government ought to be apportioned among the people according to the benefit which each receives from the protection that the government affords each person, this is impossible to be concretized. ${ }^{167}$

The application of the benefit theory to the allocation of taxing rights in DTCs between developing and developed countries would lower or even exempt taxation in relation to foreign investors. It cannot be considered as an incorrect approach, but it definitively needs to be combined with the concept of reciprocal benefits in order to be applied as a basis for a DTC between developing and developed countries.

\subsubsection{NEUTRALITY}

Relief from double taxation finds its economic support in the concept of neutrality. On this, it is necessary to analyse the relationship between the credit and exemption methods, ${ }^{168}$ and

\footnotetext{
${ }^{166}$ Souza de Man, Fernando. Taxation of Cross-Border Provisions of Services in Double Tax Conventions between Developed and Developing Countries: A Proposal for New Guidelines. PhD Thesis Maastricht University, Faculty of Law, 2013.

${ }^{167}$ Krauss, D. T. The Benefit Theory of Taxation. Tennessee Law Review, Vol 11, 1932.

${ }^{168}$ Larkins, Ernest. Double Tax Relief for Foreign Income: A Comparative Study of Advanced Economies. ATAX Discussion Paper Series 4, 2001. Available at: http://papers.ssrn.com/sol3/papers.cfm?abstract_id=623624
} 
the economic concepts of Capital Import Neutrality (CIN) ${ }^{169}$ and Capital Export Neutrality (CEN). ${ }^{170171172173}$

The exemption system could be considered as a system that provides an economic incentive for investors to invest in low-tax countries because the source tax is almost an ultimate / final tax. The exemption system does not interfere, as the credit system does, in the repatriation of benefits from the host to the residence country. From a sovereignty perspective, the exemption system is an expression of respect for the tax legislation of independent countries.

Some countries, in order to prevent taxpayers' abuse of the exemption regime by lowering the rest of their income that should be taxable at higher marginal rates, ${ }^{174}$ tend to apply the exemption with a progressive method, which is a deviation from the full exemption method. This method allows the residence country - the country of the investor - to take the exempted foreign income into account when calculating the amount of tax on the remaining domestic income and it necessarily presupposes the adoption of a progressive tax regime at the domestic level.

Under the full credit method, the residence country allows the deduction of the foreign source tax from the tax calculated on the worldwide income of the taxpayer, leaving the investor country tax rate as the final tax rate, which protects the resident country's rights to tax the income that arises from cross-border transactions. The effect of the full credit system can be altered when the tax rate of the country in which the investment is made is higher than that of the investor country. To prevent investors from offsetting domestic income against foreign

\footnotetext{
169 OECD Glossary of Tax Terms. CIN: Public finance concept to describe a situation where investments within a country are subject to the same level of taxes regardless of whether they are made by a domestic or foreign investor. The exemption method of relieving international double taxation is often considered to illustrate this principle. Available at: http://www.oecd.org/ctp/glossaryoftaxterms.htm

${ }^{170}$ OECD Glossary of Tax Terms. CEN: Public finance concept to describe a situation where investors are subject to the same level of taxes on capital income regardless of the country in which income is earned. The credit method of relieving international double taxation is often considered to illustrate this principle. Available at: http://www.oecd.org/ctp/glossaryoftaxterms.htm

${ }^{171}$ Shaheen, Fadi. International Tax Neutrality: Reconsiderations. Virginia Tax Review, Vol 27, 2007.

172 Shaheen, Fadi. International Tax Neutrality: Revisited. Tax Law Review, Vol 64, 2011.

${ }^{173}$ Knoll, Michael. Reconsidering International Tax Neutrality. Tax Law Review, Vol 64, 2011.

174 Beveridge, Fiona. The treatment and taxation and taxation of foreign investment under international law: Towards International Disciplines. Manchester University Press, 2000.
} 
credit without limits, countries tend to apply the ordinary credit method that in turn limits the foreign credit to the amount of domestic tax that would be imposed on the foreign-source income, if no credit for foreign tax were given. The origin of this limitation is the United States Revenue Act of 1921 proposed by Thomas Sewall Adams in order to limit the foreign tax credit that was enacted as a result of the United States Revenue Act of 1918. At that time, the prevalence of source countries was already acknowledged. ${ }^{175}$

If the tax rate of the host / developing country is lower than that of the investor country, this method, in the case of direct investment, ends by forcing an economic incentive for foreign investors to re-invest in the source / host country the income earned produced by the subsidiary in the host / developing country. In a sharing system of taxation, as is proposed by the UN MTC, this is certainly something that should be of interest for developing countries. In this line, the approach of a few developed countries, such as the United States until its latest tax reform in $2017,{ }^{176}$ was to eliminate double taxation through a credit method and that therefore incentivizes an unlimited deferral for income generated by foreign subsidiaries regarding foreign business operations. This approach could be considered as beneficial for developing economies. In order to tackle abusive deferrals, countries have developed the "controlled foreign companies' rule". The system created by Thomas Sewall Adams was adjusted in 1962 with the incorporation of specific legislation designed to tackle, under certain circumstances, deferrals. ${ }^{177}$

CIN means that all investors in a country - whether foreign or domestic - face the same effective tax rate on income from their investments sourced in that country. CEN means that resident investors face the same effective domestic tax rate, regardless of whether they invest at home or abroad. Both principles should be viewed from the perspective of the investor country. For example, most European countries have chosen to utilize a capital import neutral method for substantial direct investments - business dividend income - by using the

\footnotetext{
175 Graetz, Michael J.; and O'Hear, Michael M.. The 'Original Intent' of U.S. International Taxation. Duke Law Journal, Vol 46, 1997.

${ }^{176}$ United States of America, Public Law 115-97 known as "Tax Cuts and Jobs Act 2017". New Code section 245A.

${ }^{177}$ Unites States Internal Revenue Code, 952. Subpart F.
} 
participation exemption, while countries that opt for a capital export neutral method typically opt for the credit method.

In a commercial relationship with a developing country - assuming that that is the country where the investment took place, as this is the most common scenario - and a developed country - assuming that that is the country where the investor is resident, as this is the most common scenario - the relevant legislation regarding CIN or CEN is the legislation of the developed country, namely the residence country. Thus, if the residence country decides to follow the CEN principle, it will probably avoid double taxation under domestic or conventional legislation by crediting the tax paid in the source state on foreign income against the tax that should be paid in the resident state. ${ }^{178}$ The result will be that residents of the home / resident country will be forced to face their country's tax rate, being a neutral choice between local investments in their country - developed country - or international investments in the other country - developing country. ${ }^{179}$ This nullifies a developing country's ability to attract foreign investment by lowering taxes for investments made by non-residents. However, if the resident country decides to follow the CIN principle, it will probably avoid double taxation under domestic or conventional law by exempting the foreign income from the resident tax base. The result is that all the investments in the source country - the developing country - are subject to the same tax rate, regardless of the investor's residence.

In DTCs, the credit method has typically been used by Anglo-US countries and the exemption method has typically been employed by continental European countries. Both systems are recognized in the UN MTC and in the OECD MTC for the elimination of double taxation, but in both frameworks the approach is to follow the credit method with regard to passive investment income. Specifically regarding dividends, ${ }^{180}$ interest $^{181}$ and royalties, ${ }^{182}$ the UN

\footnotetext{
${ }^{178}$ Knoll, Michael. Reconsidering International Tax Neutrality. Tax Law Review, Vol 64, 2011.

179 Pistone, Pasquale; and Goodspeed, Timothy J. Rethinking tax jurisdictions and relief from international double taxation in relations with developing countries: Legal and economic perspectives from Europe and North America. International Tax Coordination, An Interdisciplinary Perspective on Virtues and Pitfalls, edited by Martin Zagler, 2010.

${ }^{180}$ United Nations, Department of Economic and Social Affairs. Model Double Taxation Convention between Developed and Developing Countries, 2017, article 10.

${ }^{181}$ Ibid, 181, Article 11.

182 Ibid, 181, Article 12.
} 
MTC adopted a CEN approach by limiting source countries' rights to tax to a certain threshold by fixing the withholding tax and granting residual taxing rights to the residence country through the mandatory application of a credit system. This approach avoids juridical double taxation - paragraph 2 of Article 23 A and Article B. As was stated, this does not apply to dividends when the resident countries domestically apply the participation exemption method.

The evolution of domestic legislation has proven that source countries can be sovereign regarding their own legislation. The incorporation of the participation exemption system has changed the status quo regarding taxation at residence and at source for dividends that arise from substantial direct investments. The incorporation of the participation exemption method dates back to the $19^{\text {th }}$ century. New Zealand was the first country to do so (via the Land and Income Tax Assessment Act of 1981). Since then, a further 27 OECD countries have adopted this approach. ${ }^{183}$

One deviation from the OECD MTC and the UN MTC approach regarding how to eliminate double taxation is the case in Germany. Germany includes an "activity clause" in its DTCs which in turn grants greater taxing rights to the source country in relation to active income and only limited taxing rights in relation to passive income, as well as granting residual taxing rights to the residence country in relation to passive income. The German activity clause normally relates to business income from permanent establishments abroad - including income from the alienation of movable and immovable property that can be attributed to such a permanent establishment - and to intercompany dividends on substantial shareholdings participation exemption. ${ }^{184}$ The German approach illustrates that it is possible to incorporate a rule that runs counter to the traditional paradigms of taxation of passive investment income.

Domestic and conventional approaches do not need to be coherent: there are numerous examples of countries that follow, for example, a credit system under domestic law and an

${ }^{183}$ Netherlands, Finland, Switzerland, Canada, Belgium, Luxembourg, Austria, France, Portugal, Italy, Denmark, Hungary, Australia, Iceland, Spain, Germany, Sweden, Czech Republic, Slovenia, Slovakia, Poland, Norway, Slovenia, Turkey, Japan, United Kingdom, and Greece.

${ }^{184}$ Lüdicke, Jurgen. Germany: Exemption and Tax Credit In German Tax Treaties - Policy and Reality. Bulletin for International Taxation, Vol 64, 2010. 
exemption system under treaty law. Nonetheless, if the choice is exactly the opposite, such as if a country follows an exemption system under domestic law and a credit system under treaty law, the non-aggravation principle must prevail, so that when the treaty imposes a higher burden than the domestic law, the domestic law nevertheless remains applicable. ${ }^{185}$

Germany and Hungary are examples of countries that have combined both systems. They use the credit system in their domestic legislation and the exemption system in treaty legislation. However, both countries usually exclude specific items of income from exemption ${ }^{186}-$ generally interest, dividends that arise from non-substantial shareholdings and royalties and apply a credit method to such incomes. Under some German tax treaties, the exempted incomes are conditioned on one important requirement for the exclusion, this is, the taxability of the relevant income in the other treaty state, so called, subject to tax clauses. ${ }^{187}$

Treaty policy in exemption countries is generally more consistent with the domestic law choice than the treaty policy of credit countries. The Netherlands and Belgium are, in effect, fairly consistent in this respect. ${ }^{188}$

${ }^{185}$ Lang, Michael; Pistone, Pasquale; Schuch, Josef; Staringer, Claus; Storck, Alfred; and Zagler, Martin. Tax Treaties: Building Bridges between Law and Economics. IBFD, 2010.

186 As an example, Germany exempts business income attributable to a foreign permanent establishment including gains on the sale of assets belonging to the permanent establishment, foreign personal service income, both independent and dependent, and income from foreign real property including gains on the sale.

${ }^{187}$ Protocol of the Double Tax Convention between the United States of America and the Federal Republic of Germany (1989), Example $\mathrm{N}^{\circ}$ 21: "With reference to Article 23 (Relief from Double Taxation) and Article 25 (Mutual Agreement Procedure) The Federal Republic of Germany shall avoid double taxation by a tax credit as provided for in paragraph 2 b) of Article 23, and not by a tax exemption under paragraph 2 a) of Article 23, a) if in the Contracting States income or capital is placed under differing provisions of the Convention or attributed to different persons (other than under Article 9 (Associated Enterprises)) and this conflict cannot be settled by a procedure pursuant to Article 25 and aa) if as a result of such placement or attribution the relevant income or capital would be subject to double taxation; or bb) if as a result of such placement or attribution the relevant income or capital would remain untaxed or be subject only to inappropriately reduced taxation in the United States and would (but for the application of this paragraph) remain exempt from tax in the Federal Republic of Germany; or b) if the Federal Republic of Germany has, after due consultation and subject to the limitations of its internal law, notified the United States through diplomatic channels of other items of income to which it intends to apply this paragraph in order to prevent the exemption of income from taxation in both Contracting States or other arrangements for the improper use of the Convention. In the case of a notification under subparagraph $b$ ), the United States may, subject to notification through diplomatic channels, characterize such income under the Convention consistently with the characterization of that income by the Federal Republic of Germany. A notification made under this paragraph shall have effect only from the first day of the calendar year following the year in which it was transmitted and any legal prerequisites under the domestic law of the notifying State for giving it effect have been fulfilled.".

${ }^{188}$ Lang, Michael; Pistone, Pasquale; Schuch, Josef; Staringer, Claus; Storck, Alfred; and Zagler, Martin. Tax Treaties: Building Bridges between Law and Economics. IBFD, 2010. 
For developing countries, the discussion about the fairness in DTCs concluded with developed countries has always been centred on whether or not it results in a benefit in the allocation of taxing rights approach adopted, forgetting the importance of how the residence country eliminates double taxation and the effects that such a mechanism can generate.

In South America - a geographic area that consists of both developing and less developed countries - this discussion was important in the 1970s and 1980s, especially due to the work of the influential Professor Ramón Valdes Costa. ${ }^{189}$

The combination of Articles 10,11 and 12 of the UN MTC with the use of a credit system, the approach laid down in paragraph 2 of Article 23 A and by Article 23 B of the MTC, is the only way to solve the eclectic approach of sharing taxing rights in relation to passive investment income. There is no need to continue with that approach if the UN MTC actually manages to provide developing countries with what they really need, namely incentives to attract foreign investment and, therefore, development.

\subsubsection{THEORIES APPLIED TO PASSIVE INVESTMENT INCOME- LEAGUE OF NATIONS - OECD MTC - UN MTC}

The allocation of passive income proves to be an acute issue, particularly in DTCs between developed and developing countries. The choices for tax allocation on interest, dividends and royalties range from a total ban to full taxation at source.

The OECD MTC and UN MTC approaches vary according to the differences among their member countries. Developing countries normally claim a partial allocation of passive

\footnotetext{
189 See: Valdés Costa, Estudios de Derecho Tributario Internacional, Montevideo, 1978; Estudios de Derecho Tributario Latinoamericano, Montevideo, 1982; Instituciones de Derecho Tributario, Buenos Aires, 1992; Curso de Derecho Tributario, Bogotá, Buenos Aires and Madrid, 1996; Ponencias y comunicaciones presented at the XVII seminars ILADT, Montevideo, 1997; and in Ramón Falcón y Tella, Tendencias actuales en los criterios de sujeción al tributo: Hacia la territorialidad. Crónica Tributaria $\mathrm{N}^{\circ}$ 100, 2001. Available at: http://www.ief.es/documentos/recursos/publicaciones/revistas/cron_trib/articulo_100_Falcon.PDF
} 
investment income whenever they are the source country. For more than 40 years, many DTCs have been signed that follow this idea. In this period of time, very few developing countries have improved their degree of development or matched the objectives indicated for each kind of income.

While the UN MTC grants more taxing rights, i.e., benefits, to the source country, the OECD MTC does not. However, in respect of passive investment income, the only relevant difference between both concerns the treatment of royalties. The UN MTC displays a source approach. ${ }^{190}$ As to the OECD MTC, ${ }^{191}$ royalties are taxable in the hands of the recipient and no taxing rights are allocated to the source country, i.e., the country where the technology / intellectual property under the scope of the royalty provision has been used. On the contrary, the UN MTC allocates taxing rights to the source country through a limited withholding tax. This different approach in the UN MTC seeks to avoid a hypothetically unjustified loss of tax revenue for the source country, ${ }^{192}$ which could theoretically follow from the application of the OECD MTC. Royalty payments are typically tax deductible in the source country and therefore the prohibition on taxing at source could lead to a loss of tax revenue.

The UN MTC also differs from the OECD MTC because of the possibility to set the percentage of the withholding tax on passive investment income to be charged by the source country during DTC negotiations. An analysis of the treaties in force shows that, in treaties based on the UN MTC, withholding tax rates are not higher than the ones recommended by the OECD MTC. In fact, in these cases, whenever the withholding taxes are too high ${ }^{193}$ and a country fears losing foreign investment, the agreements result in similar or even lower tax rates than the rates proposed by the OECD MTC. Daurer and Krever proved the above in a

\footnotetext{
190 See Article 12 of the United Nations Model Double Taxation Convention between Developed and Developing Countries, 2017.

${ }^{191}$ See Article 12 of the OECD Model Tax Convention on Income and Capital, 2017.

192 Gerendy, Zoltan. The future of source taxation at passive income in Tax treaty policy and development. Vienna: Linde Verlag, 2005.

193 This statement assumes that the resident country avoids double taxation by granting a credit as is stated in paragraph 2 of Article $23 \mathrm{~A}$ and Article $23 \mathrm{~B}$ of the UN MTC. If one country departs from that approach, i.e. exempting dividends from taxation at the recipient level, the statement is not therefore applicable. In this last situation, the increase of withholding taxes at source definitely affects foreign investment.
} 
study concerning a number of African countries. ${ }^{194}$ They demonstrated that even though the UN MTC leaves the withholding tax rate for dividends open, for the purposes of dividends derived from business investments - FDI - many of the target countries repeatedly stick to the $5 \%$ rate contained in the OECD MTC or even lower rates in some cases. The withholding tax rate for portfolio dividends set forth in the OECD MTC is currently 15\%. The treaties signed by Burundi, Ethiopia and Rwanda are dominated by withholding tax rates lower than 15\%. Mozambique, Uganda and Zambia consistently include either the OECD rate or a lower rate. In Uganda and Zambia, the higher rates are mainly included in treaties with OECD countries and the lower rates are typically found in treaties with non-OECD or other African countries. Kenya, Tanzania and Zimbabwe have been more successful in negotiating a withholding tax rate that is higher than $15 \%$ in more than half of their treaties.

Regarding interest, 11 of the countries that were tested in Daurer and Krever's study have mainly adopted the $10 \%$ withholding tax rate that is stipulated by the OECD MTC. Ethiopia seems to have negotiated less source taxing rights in half of its treaties (mainly with African or non-OECD countries) and has included a withholding tax rate that is lower than $10 \%$. Kenya and Tanzania, by way of contrast, were more successful in adopting higher tax rates than the OECD MTC ones. Thus, the difference mentioned above between the MTCs can be seen as no more than a formal difference.

With regard to the allocation of taxing rights approach that was adopted in DTCs on passive investment income, an international consensus appeared in the 1920s and it has remained unchanged until now. Defined by Peggy Musgrave as "international equity", 195 the topic has been extensively studied by her, Richard Musgrave, ${ }^{196}$ Klaus Vogel ${ }^{197}$ and by the four

\footnotetext{
${ }^{194}$ Daurer, Veronica; and Krever, Richard. Choosing between the UN and the OECD Tax Policy Models: an African Case Study. European University Institute, Florence: Robert Schuman Centre for Advanced Studies. Working Paper RSCAS 2012/60.

${ }^{195}$ Musgrave, Peggy B. United States taxation of foreign investment income: issues and arguments. Cambridge: International Tax Program, Law School of Harvard, 1969.

${ }^{196}$ R. Musgrave. Criteria for foreign tax credit. Taxation and Operations Abroad. Symposium. Ed. Russell Baker, 1960. P. 83.

${ }^{197}$ Vogel, Klaus. Worldwide vs. Source taxation of income: A review and reevaluation of arguments. Influence of Tax Differentials on International Competitiveness. VIII Munich Symposium on International Taxation, Kluwer law and Taxation Publishers, Deventer - Boston, 1990. p. 119.
} 
economists ${ }^{198}$ that were appointed by the LN in the 1920s. The LN's work in this regard, as well as adherence to the underlying theory of economic allegiance, are important for understanding the development of this topic.

As mentioned, a group of economists concluded the LN Report on double taxation in 1923. This report dealt with the problem of double taxation by applying the economic allegiance theory, which underlies the modern discussion on tax jurisdiction. The report analysed, at length, the problems connected with the choice of either residence or source taxation as the basis for tax jurisdiction. It pointed out that an income tax based on the ability to pay does not answer the question of whose ability to pay is to be considered in each taxing jurisdiction. The group of economists considered that the individual whole's faculty should be taxed - the aim of the "ability to pay theory" - but that it should be taxed only once and that the revenue should be divided among the tax districts according to the relative interest of the taxpayer in each district. ${ }^{199}$

When the first DTC was concluded more than 100 years ago, ${ }^{200}$ the distribution of taxable income between treaty partners was done by allocating the right to tax to only one of the contracting countries, thereby making the income tax exempt in the other country. That approach started to change at the beginning of the $20^{\text {th }}$ century, when the United States of America and the United Kingdom introduced a tax credit in their domestic legislation as the method to eliminate cross-border juridical double taxation. The credit approach became popular and it was subsequently introduced into the OECD MTC, and therefore into the UN MTC, as the appropriate method to eliminate double taxation in relation to passive investment income.

Nowadays, notwithstanding that both the OECD MTC and the UN MTC use the credit method to eliminate double taxation of passive investment income, 28 out of the 34 current

\footnotetext{
${ }^{198}$ Professors Bruins, Einaudi, Seligman, and Sir Josiah Stamp.

${ }^{199}$ League of Nations, Economic and Financial Commission, Professors Bruins, Einaudi, Seligman, and Sir Josiah Stamp. Report on Double Taxation submitted to the Financial Committee, 1923. Available at: http://www.taxtreatieshistory.org/.

${ }^{200}$ Treaty between Austria-Hungary and Prussia for the Avoidance of Double Taxation. 1899. League of Nations Document E.F.S. 40 F. 15, RGBI 158/1900.
} 
OECD member countries use the participation exemption system (the other internationally accepted method to eliminate juridical double taxation and that does not mean a territorial system) in relation to qualifying dividends received from foreign subsidiaries that are resident in some or all countries. Out of those 28 countries, 20 countries exempt $100 \%$ of the dividends and eight countries exempt between $95 \%$ and $100 \%$ of the dividends. As a consequence, the tax treatment in this regard by most OECD members deviates from the approaches that are contained in both the OECD MTC and the UN MTC. ${ }^{201}$

\begin{tabular}{|c|c|c|}
\hline \multicolumn{2}{|c|}{ Worldwide taxation with Exemption on qualifying } & Worldwide taxation with \\
dividends & Foreign Tax Credit \\
\hline Australia & Japan & Chile \\
\hline Austria & Luxembourg & Ireland \\
\hline Belgium & Netherlands & Israel \\
\hline Canada & New Zealand & United States \\
\hline Czech Republic & Norway & Mexico \\
\hline Denmark & Poland & \\
\hline Estonia & Portugal & \\
\hline Finland & Slovakia & \\
\hline France & Slovenia & \\
\hline Germany & Spain & \\
\hline Greece & Sweden & \\
\hline Hungary & Switzerland & \\
\hline Iceland & Turkey & \\
\hline Italy & United Kingdom & \\
\hline
\end{tabular}

The LN economists tried to establish the location of the true economic interest of the taxpayer. For this purpose, they developed an elaborate test that aimed to define the true meaning of economic allegiance and then defined the ways in which economic allegiance should be allocated. The report considered two out of the four bases to determine economic allegiance as being the most important: (1) the acquisition of wealth "origin" or source, and (2) the consumption of wealth "domicile" or residence. The other two remaining bases refer

201 PWC Report. Evolution of Territorial Tax Systems in the OECD, 2013. Available at http://www.techceocouncil.org/clientuploads/reports/Report\%20on\%20Territorial\%20Tax\%20Systems_2013 0402b.pdf 
to the place where the wealth is located and where the rights in relation to the wealth can be enforced.

The next task for the group of economists was to address "the evil consequences of double taxation". 202 The underlying question was: “(...) which Government should give up revenue, and to what extent?"203 The methods explored by the economists were: (1) deduction for income from abroad, ${ }^{204}$ (2) exemption for income going abroad, ${ }^{205}$ (3) division of the tax, ${ }^{206}$ and (4) classification and assignment of income. ${ }^{207}$

The recommendation made by the LN group of economists was to exempt income going abroad. By bypassing that approach, the Technical Experts in their first report in $1925^{208}$ opted to give more value to the "classification and assignment of income" method by remarking that: "All the treaties concluded between the Central European States both before and after the war in the main followed quite definitively the last system mentioned by the economists, namely, the system of the assignment of income, that is to say, apportionment according to country of origin". ${ }^{209}$ Even though the Technical Experts ${ }^{210}$ openly stated that

${ }^{202}$ League of Nations, Economic and Financial Commission, Professors Bruins, Einaudi, Seligman, and Sir Josiah Stamp. Report on Double Taxation submitted to the Financial Committee, 1923. Available at: http://www.taxtreatieshistory.org/.

203 Ibid, 203.

${ }^{204}$ Ibid, 203.

${ }^{205} \mathrm{Ibid}, 203$.

${ }^{206}$ Ibid, 203. See also Musgrave, Richard A. Fiscal Systems, New Haven: Yale University Press, 1969. p. 238

${ }^{207} \mathrm{Ibid}, 203$.

${ }^{208}$ Technical Experts. Report and Resolutions on Double Taxation and Tax Evasion submitted to the Financial Committee of the League of Nations, 1925. Available at: http://www.taxtreatieshistory.org/

${ }^{209}$ Coates, W. H. Double Taxation and Tax Evasion. Journal of the Royal Statistical Society, Vol 88, 1925.

${ }^{210}$ Dr. Salvador Oria, Secretary of State in the Minister of Finance, Member of the board of the National Mortgage Bank, Argentina - replaced at the third session by M. Julian Enciso, Councillor of Legation, Geneva; M. Ch. Clavier, Director-General Direct Taxation and Land Survey in the Minister of Finance, Belgium; Dr. Vladimir Valnicek, Chief of Section in the Ministry of Finance - replaced at the third session by HE Dr. Bohumil Vlasak, Minister Plenipotentiary, Head of Department in the Ministry of Finance, Czechoslovakia; M. Borduge, Councillor of State, Director-General of Taxation and Registration, Ministry of Finance, France; Dr. Herbert Dorn, Director in the Ministry of Finance, Germany; Sir Percy Thompson, Deputy Chairman, Board of Inland Revenue, Great Britain; Professor Pasquale d' Aroma, Vice-Governor of the Bank of Italy, late Director-General in the Ministry of Finance. Assistant Dr. Gino Bolaffi, Head of Section in the Ministry of Finance, Department of Direct Taxation, Italy; Mr. Kengo Mori, Financial Commissioner of Japan in London - replaced by Mr. Takashi Aoki, Representative in London of the Bank of Japan. Assistant M. Yamaji, Japanese Delegation to the Reparation Commission, Japan; Dr. JHR Sinninghe Damste, Director-General of Taxation. For Colonial questions: Dr. LJ van der Waals, Director in the Colonial Department, The Netherlands; Professor Stefan Zaleski, Professor of Political Economy at the University at Posen. Assistant - for questions of succession duties - M. Edouard Werner, Head of Department, Ministry of Finance, Poland; M. Hans Blau, Director of the Federal 
their conclusion was made "(...) for purely practical purposes and no inference in regard to economic theory or doctrine should be drawn from this fact", ${ }^{211}$ this to date nevertheless remains as the appropriate approach and governs most DTCs in force.

As previously mentioned, that decision can be considered as the origin of the historical problem of the allocation of taxing rights for developing countries when they sign DTCs. That approach must be complemented with the doctrine of economic allegiance, which was recommended by the economists' report in order to ascertain the location of the individual's true economic interest, ${ }^{212}$ with the main aim being the determination of the allocation of taxes between the two contracting states. This is confirmed by the fact that the early works of the LN only considered the interests of developed countries.

The concerns of developing countries, however, arose during the negotiations of the MTC in Mexico. In this meeting, the Latin American countries challenged the criteria adopted in previous works. The majority of their approaches to passive investments were later rejected by the London MTC.

Historically, developing countries have had doubts as to the benefits of this traditional approach (e.g. LN, OECD and UN). The traditional approach was applied in the "1928 Geneva Model Conventions". It was also recommended, with some minor changes, by the OECD MTC in 1963 and by the UN MTC in 1980.

Peggy Musgrave's early works also addressed the problem of international equity. For her, international equity was based on the rights of the home / resident and the host / source

Taxation Department, Switzerland; Professor Thomas S. Adams, President of the American Economic Association, former Economic Adviser to the USA Treasury Department, Professor at Yale University. Assistants: Mr. Mitchell B. Carroll, Chief of Tax Section, Department of Commerce and Miss Annabel Matthews, Attorney, attached to the Board of Inland Revenue, Treasury Department, United States of America; Dr. Federico Alvarez Feo, Professor of Finance at the University of Caracas, Venezuela.

${ }^{211} \mathrm{Ibid}, 203$.

${ }^{212}$ This phrase must be understood as the application of the economic allegiance theory according to League of Nations, supra note 200. The committee pointed to four elements in the concept of economic allegiance: (i) where the yield is physically or economically produced? [production of wealth]; (ii) where the final results of the process are actually to be found? [possession of wealth]; and (iii) where does the wealth reach the final owner [disposition of wealth]? 
countries in terms of an equitable division of national gain and loss. ${ }^{213}$ The underlying idea was that a taxpayer's home country has rights in relation to the taxpayer's foreign income because the home country has an initial interest in all of its taxpayers' capital and income. Thus, a tax imposed by the host country results in a loss to the home country. ${ }^{214}$

Peggy Musgrave's most recent theory departs from that former approach, considering it as a ground for the solution the national "entitlements" of the home and the host countries. While the entitlements of the home country address the right to tax residents' worldwide income, the entitlements of the host country address the right of source countries to tax income that arises within its geographical borders. ${ }^{215}$ Musgrave addresses the fact that international equity concerns the extent of the source country's entitlement, i.e. the host country's share of international income. ${ }^{216}$ Specifically, and regarding the share of international income, ${ }^{217}$ Musgrave argues for an agreed rate schedule for corporate tax and withholding tax, where tax rates would relate inversely to per capita income in the host country and directly to per capita income in the home country. She supported this approach by recognizing that: (1) the right of the host country is based on the territoriality principle, tempered by the principle of non-discrimination; and (2) the right of the home country is based on the following principles:

(a) the taxpayer's tax allegiance to the home country arising from their legal rights as citizens;

\footnotetext{
${ }^{213}$ Musgrave, Richard A.; and Musgrave, Peggy B. Inter-nation Equity in Modern Fiscal Issues: Essays in Honor of Carl S. Shoup, edited by Richard Bird and John Head, Toronto, 1972.

${ }^{214} \mathrm{Li}$, Jinyan. Globalization and the Impact of Tax on International Investments: A Symposium in Honour of the Memory of the Late Alex Easson. Queen's University, 2008. Introduction. Alex Eassons's statement: “There is no real agreement as to what would be a proper division of the [international] tax base, nor is there any obvious principle of fairness that can be invoked to justify any particular distribution of revenue. The present division has been a more or less accidental result of the attempt to eliminate double taxation, and is principally a product of the various model double taxation treaties that have been adopted over a period of some 60 years. Since the principal architects of these model treaties have been the major capital-exporting countries, it seems reasonable to suppose that, to the extent that the existing arrangements are inequitable, they operate to the prejudice of countries that are primarily importers of capital ... and as the great majority of lesser-developed countries fall into this category, there is the further consideration that some redistribution in favour of source countries would on balance be desirable and would promote a form of vertical equity among nations. "

215 Musgrave, Peggy B. Consumption Tax Proposals in an International Setting. Tax Law Review, Vol 54, 2000-2001.

${ }^{216}$ Kaufman, Nancy H. Fairness and the taxation of international income. Law and Policy International Business, Vol 29, 1998.

${ }^{217}$ Richman (then Musgrave), Peggy B. Taxation of Foreign Income - An Economic Analysis. Johns Hopkins Press, 1963.
} 
(b) the necessity to achieve inter-individual equity;

(c) the home country's tax sovereignty in relation to the property of residents which may be considered to be national resources; and

(d) the benefit theory, which considers taxation as a payment for the benefits provided by the country of residence to its own factors of production prior to their transfer abroad. ${ }^{218}$

Musgrave's approach focuses on the host country's share of the worldwide income, understanding that the home country's right to tax worldwide income is "untouchable". Such an approach is the one that is followed by the OECD MTC and by the UN MTC regarding the taxation of passive investment income, at least since the first OECD MTC that was adopted in 1963, as well as with the first UN MTC in 1980. By exempting qualifying dividends, developed countries - most of them home or resident countries in DTCs with developing countries - have unilaterally given up their taxing right in this regard.

Ascertaining the location of the true economic interest of the taxpayer based on an economic classification and assignment approach is a valid method for allocating international income between countries that are party to a DTC. However, such an allocation method must consider that: (1) domestic legislation usually does the same, ${ }^{219}$ and (2) the existence of mostly unilateral investments flows in relations between developing and developed countries.

It is valid to question whether the economic classification and assignment approach inherited from the 1928 Geneva Model is suitable for the negotiation of a DTC between developing and developed countries. The immediate effect for developing countries when they sign a DTC with a developed country is the resignation of sovereignty, i.e. rights to tax, and this loss is not properly compensated.

\footnotetext{
218 Kaufman, Nancy H. Fairness and the taxation of international income. Law and Policy International Business, Vol 29, 1998.

219 Azzi, John. Policy Considerations in the Taxation of Foreign-Source Income. Bulletin for International Fiscal Documentation, Vol 47, 1993.
} 
The traditional argumentation of developing countries against this harmful effect is the decrease in fiscal revenues that result from the application of DTCs, compared to scenarios where there is no DTC. Taking this line of argumentation as a starting point, DTCs between developing and developed countries must not only solve the problem of double taxation that is quite often solved unilaterally by domestic legislation - but they must also provide an incentive to increase the attraction of foreign investment, access to foreign debt and access to beneficial technology.

In a scenario where there is no DTC between a capital-importing country (which is typically the host / source state, i.e. the developing country) and a capital-exporting country (in the majority of cases the home / residence state, i.e. the developed country), source countries will tend to fully tax all income that is sourced within their jurisdiction. This leaves the residence country only with a residual right to tax. Nowadays most developed countries, namely 32 out of 35 OECD Members, unilaterally avoid cross-border juridical double taxation in their domestic legislation. 220221

\footnotetext{
${ }^{220}$ Information obtained from the IBFD Tax Research Platform. Available at: https://research.ibfd.org/

${ }^{221}$ Australia: Yes. Juridical Double Taxation is unilaterally avoided without the need of having a DTC in force (last reviewed January 1, 2015); Austria: Yes. Juridical Double Taxation is unilaterally avoided without the need of having a DTC in force. Exemption with progression for active income and credit for passive income (last reviewed January 19, 2015); Belgium: Yes. Juridical Double Taxation is unilaterally avoided without the need of having a DTC in force. Tax Exemption or Tax Credit (last reviewed January 14, 2015); Canada: Yes. Juridical Double Taxation is unilaterally avoided without the need of having a DTC in force. Tax Credit for active and passive income. Indirect Tax Credit for dividends. (last reviewed January 19, 2015); Chile: Yes. Juridical Double Taxation is unilaterally avoided without the need of having a DTC in force. Ordinary Tax Credit with some restrictions, and deduction. (last reviewed January 1, 2015); Czech Republic: No. Juridical Double Taxation is not unilaterally avoided (last reviewed January 12, 2015); Denmark: Yes. Juridical Double Taxation is unilaterally avoided without the need of having a DTC in force. Ordinary Tax Credit. (last reviewed January 12, 2015); Estonia: Yes. Juridical Double Taxation is unilaterally avoided without the need of having a DTC in force. Ordinary Tax Credit. (last reviewed January 22, 2015); Finland: Yes. Juridical Double Taxation is unilaterally avoided without the need of having a DTC in force. Ordinary Tax Credit. (last reviewed January 12, 2015); France: Partially. Juridical Double Taxation unilaterally only partially avoided by deduction (last reviewed January 16, 2015); Germany: Yes. Juridical Double Taxation is unilaterally avoided without the need of having a DTC in force. Ordinary Tax Credit. (last reviewed January 19, 2015); Greece: Yes. Juridical Double Taxation is unilaterally avoided without the need of having a DTC in force. Ordinary Tax Credit. (last reviewed January 23, 2015); Hungary: Yes. Juridical Double Taxation is unilaterally avoided without the need of having a DTC in force. Ordinary Tax Credit/ Limit until 90\% Foreign Tax. (last reviewed April 1, 2015); Iceland: Yes. Juridical Double Taxation is unilaterally avoided without the need of having a DTC in force. Ordinary Tax Credit. (last reviewed January 21, 2015); Ireland: Yes. Juridical Double Taxation is unilaterally avoided without the need of having a DTC in force. Ordinary Tax Credit or Deduction. (last reviewed January 20, 2015); Israel: Yes. Juridical Double Taxation is unilaterally avoided without the need of having a DTC in force. Ordinary Tax Credit. (last reviewed January 19, 2015); Italy: Yes. Juridical Double Taxation is unilaterally avoided without the need of having a DTC in force. Ordinary Tax Credit. (last reviewed January 15, 2015); Japan: Yes. Juridical Double Taxation is unilaterally avoided without the need of having a DTC in force. Ordinary Tax Credit or
} 


\subsubsection{WITHOLDING TAXES}

In a DTC, a withholding tax is the most common mechanism that is used to tax non-residents in relation to source income. This requires the payer - the withholding agent - to withhold and pay, in the name of the non-resident taxpayer, the source country tax in relation to the source passive investment income. Withholding taxes derive their name from the way they are collected: by being withheld by the debtor and paid directly by him to the government. ${ }^{222}$

The historic agreement since the 1963 OECD MTC until now of sharing taxing rights between the source and the residence country regarding passive investment income ${ }^{223}$ results in this method of taxation at source - the withholding tax - being the most widespread

Deduction. (last reviewed January 30, 2015); Korea: Yes. Juridical Double Taxation is unilaterally avoided without the need of having a DTC in force. (last reviewed January 30, 2015); Luxemburg: Yes. Juridical Double Taxation is unilaterally avoided without the need of having a DTC in force. Ordinary Tax Credit or Deduction. (last reviewed January 15, 2015); Mexico: Yes. Juridical Double Taxation is unilaterally avoided without the need of having a DTC in force. (last reviewed January 1, 2015); Netherlands: Yes. Juridical Double Taxation is unilaterally avoided without the need of having a DTC in force. Tax Credit, Exemption, and Deduction. (last reviewed January 12, 2015); New Zealand: Yes. Juridical Double Taxation is unilaterally avoided without the need of having a DTC in force. (last reviewed January 1, 2015); Norway: Yes. Juridical Double Taxation is unilaterally avoided without the need of having a DTC in force. Ordinary Tax Credit. (last reviewed January 12, 2015); Poland: Yes. Juridical Double Taxation is unilaterally avoided without the need of having a DTC in force. Ordinary Tax Credit. (last reviewed January 1, 2015); Portugal: Yes. Juridical Double Taxation is unilaterally avoided without the need of having a DTC in force. Ordinary Tax Credit. (last reviewed April 7, 2015); Slovak Republic: No. Juridical Double Taxation is not unilaterally avoided (last reviewed February 1, 2015); Slovenia: Yes. Juridical Double Taxation is unilaterally avoided without the need of having a DTC in force. Ordinary Tax Credit. (last reviewed January 30, 2015); Spain: Yes. Juridical Double Taxation is unilaterally avoided without the need of having a DTC in force. Ordinary Tax Credit and Exemption. (last reviewed March 1, 2015); Sweden: Yes. Juridical Double Taxation is unilaterally avoided without the need of having a DTC in force. Ordinary Tax Credit and Deduction. (last reviewed January 13, 2015); Switzerland: Yes. Juridical Double Taxation is unilaterally avoided without the need of having a DTC in force. Exemption and Deduction. (last reviewed March 1, 2015); Turkey: Yes. Juridical Double Taxation is unilaterally avoided without the need of having a DTC in force. Ordinary Tax Credit. (last reviewed January 1, 2015); United Kingdom: Yes. Juridical Double Taxation is unilaterally avoided without the need of having a DTC in force. Ordinary Tax Credit or Deduction. (last reviewed February 20, 2015); United States of America: Yes. Juridical Double Taxation is unilaterally avoided without the need of having a DTC in force. Direct and Indirect Tax Credit. (last reviewed January 1, 2015).

${ }^{222}$ Zimmer, Frederik. Withholding taxes. University of Oslo, 2008. Available at: http://www.eatlp.org/uploads/public/Withholding\%20Tax1.doc

${ }^{223}$ Regarding Royalties, the approach of share taxing rights between the source and the residence country was only included in the United Nations, Department of Economic and Social Affairs, Model Double Taxation Convention between Developed and Developing Countries, 1980. 
method to tax non-residents in relation to source income, even if it goes against the main objective of DTCs, which is the avoidance of juridical double taxation. This apparent contradiction can be caused because the decision to grant taxing rights to the source country through withholding taxes could be considered as a reaction to the problem of tax evasion the avoidance of double non-taxation - rather than on the elimination of double taxation. At the same time, and from a perspective of revenue, the increase of international capital mobility with highly integrated operations has increased the importance of withholding taxes as the easiest source taxation system in relation to passive investment income. Lastly, a withholding tax offers the tax authorities of source countries a relatively effective means of collection, which is justified on the grounds that the courts of one jurisdiction are reluctant and usually decline to enforce the revenue law of another jurisdiction. Even if foreign courts were willing to enforce source countries' legislation, the additional effort and expense of having to enforce judgments in a foreign jurisdiction would be a major disincentive to collection. $^{224}$ Thus, the mitigation of tax evasion, the simplicity of the implementation and the effectiveness of capturing passive income flows crossing national borders are the arguments that have been posited in favour of containing withholding taxes in DTCs. ${ }^{225}$

Each passive investment income has special and different features that serve to justify (or not) the existence of source taxation. Regarding interest, the primary economic justification for taxation at source has always been that interest payments are deductible expenses in the source country. Unlike taxing interest at source, withholding taxes on dividends cannot be as compellingly justified on economic grounds, since the underlying profits from which dividends are paid have usually already borne the corporate income tax of the source country. ${ }^{226}$ Regarding royalties, the UN justified the difference with the OECD MTC as the way to solve an unjustified position for the source country in the application of treaties founded on the OECD MTC since, according to the same logic that is applied to interest, royalty payments are typically tax-deductible items in the source country and, as has already

\footnotetext{
${ }^{224}$ Greig, John A. Aspects of Interest Withholding Tax. Revenue Law Journal, Vol 3, 1993. Available at: http://classic.austlii.edu.au/au/journals/RevenueLawJ1/1993/4.pdf

${ }^{225}$ Zee, Howell H. Taxation of Financial Capital in a Globalized Environment: The role of withholding taxes. National Tax Journal, Vol 51, 1998. Available at: http://www.ntanet.org/NTJ/51/3/ntj-v51n03p587-99taxation-financial-capital-globalized.pdf.

${ }^{226}$ Ibid, 226.
} 
been stated, the prohibition on taxing at source leads to a hypothetically unjustified loss of tax revenue for the source country. ${ }^{227}$

There is no consensus between developed and developing countries regarding the existence of withholding taxes in relation to all passive investment income and, even if there is partial consensus, it has been impossible to agree on the rate of each of those withholding taxes.

It seems that withholding taxes have never been an adequate method to allocate taxing rights and, in their defence, this should not be their responsibility. At least not in the way that they have been used in the UN MTC. The main purpose of withholding taxes in DTCs is to avoid double non-taxation, which they achieve by generating juridical double taxation and consequently distorting equity.

So far, withholding taxes have been instruments to mitigate tax evasion, simplify source taxation of non-residents and improve the collection of taxes in relation to passive income flows. Source countries insist on protecting their rights by raising withholding taxes. ${ }^{228}$ The UN MTC has not been able to stipulate fixed rates of withholding taxes due to the different expectations of developing and developed countries in this ambit.

In addition to the above, the main problem of withholding taxes is probably the fact that they tax on a gross basis instead of on a net basis. Consequently, it leads to excess credits and hence double taxation. High withholding taxes at source, with or without a DTC in force, may damage, due to the risk of excess of credit, the foreign investor's position. Withholding taxes try to arrive at the amount of tax that would have been imposed on net income if an adequate cross-border allocation of deductions were possible. The above scenario is even worse when the MTC - that should in theory recommend the best rules for DTCs between

${ }^{227}$ Gerendy, Zoltan. The future of source taxation at passive income in tax treaty policy and development. Vienna: Linde Verlag, 2005.

${ }^{228}$ See: Alm, James; Martinez-Vasquez, Jorge; and Rider, Mark (eds). The Challenges of Tax Reform in a Global Economy. Springer, 2006. p. 142; and Bird, Richard M.; and de Jantscher, Casanegra. Improving Tax Administrations in Developing Countries. International Monetary Fund, 1992. p. 33. 
developing and developed countries - leaves the tax rate of withholding taxes regarding passive investment income open to treaty negotiations. ${ }^{229}$

Withholding taxes are not only used in DTCs. In domestic situations, withholding taxes do not ultimately lead to a problem if, as is generally the case, the difference is refunded where the final tax bill is less than the tax that has been withheld. ${ }^{230}$ However, in the international context this is not the same, specifically regarding the taxation of passive investment income, since countries imposing withholding taxes on non-residents do not, as a rule, make refunds based on the recipient's tax position. ${ }^{231}$ This not only affects the attraction of foreign investment income and therefore development, but it also conflicts with the nondiscrimination principle that is contained in Article 24 of the UN MTC. ${ }^{232}$

It could be said that the UN MTC follows the approach of sanctioning discrimination in Article 24 and creating discrimination in Articles 10, 11 and 12. It is a common treaty practice to levy withholding taxes on the gross income in relation to dividends, interests and royalties - certainly over royalties if the treaty follows the UN MTC - which in the majority of cases differs from the tax treatment of resident taxpayers who are assessed on a net basis. The only way to diminish the impact of this contradiction is to reduce withholding tax rates to zero. ${ }^{233}$ This approach, however, is the opposite of what has been done by the UN.

\footnotetext{
${ }^{229}$ United Nations, Department of Economic and Social Affairs, Model Double Taxation Convention between Developed and Developing Countries, 2017. Articles 10, 11, and 12.

${ }^{230}$ Larking, Barry; and van der Jagt, Robert. The case for withholding tax on a net basis within the EU. International Tax Review, Vol 21, 2010.

${ }^{231} \mathrm{Ibid}, 231$.

${ }^{232}$ United Nations, Department of Economic and Social Affairs, Model Double Taxation Convention between Developed and Developing Countries, 2017. Article 24 paragraph 1: "Nationals of a Contracting State shall not be subjected in the other Contracting State to any taxation or any requirement connected therewith which is other or more burdensome than the taxation and connected requirements to which nationals of that other State in the same circumstances, in particular with respect to residence, are or may be subjected. This provision shall, notwithstanding the provisions of Article 1, also apply to persons who are not residents of one or both of the Contracting States.".

${ }^{233}$ Farrel, Jennifer E. The Interface of International Trade Law and Taxation. IBFD, Doctoral Series 26, 2013.
} 


\subsubsection{BRIC COUNTRIES AND WITHHOLDING TAXES IN DTCS}

Brazil, Russia, India and China do not represent the same interests as developing countries. Since 2001, when Goldman Sachs issued the report "Building Better Global Economic BRICs", 234 it has been possible to detect certain features in these countries' international tax policies regarding the taxation of passive investment income. Notwithstanding the interest of those countries in DTCs is completely different to those of developing or less developed countries, those features, or new approaches, are interesting for the purposes of this research as they constitute new ways of understanding the forces of international taxation.

From 2001 onwards, Brazil has signed nine ${ }^{235}$ DTCs, Russia has signed $12^{236}$ DTCs, India has signed $19^{237}$ DTCs, and China has signed $36^{238}$ DTCs. The majority of the DTCs follow the OECD MTC regarding the rates of withholding taxes, but, in some cases, there are interesting surprises due to the elimination of taxation at source in relation to some passive investment income.

BRICS countries are no longer regarded as developing countries. They are industrialized countries that fall somewhere between developing and developed countries, with strong economies and bargaining positions in the negotiation of DTCs. This economic step above developing countries means they have different aims when signing a DTC, since now, in the

\footnotetext{
${ }^{234}$ Goldman Sachs. Building Better Global Economic BRICs. Global Economics Paper 66, 2001. Available at: http://www.goldmansachs.com/our-thinking/archive/archive-pdfs/build-better-brics.pdf

${ }^{235}$ Chile (2001), Ukraine (2002), Israel (2002), Mexico (2003), South Africa (2003), Russia (2004), Venezuela (2005), Peru (2006), and Trinidad y Tobago (2008).

${ }^{236}$ Argentina (2001), Oman (2001), Singapore (2002), Estonia ((2002), Botswana (2002), Venezuela (2003), Mexico (2004), Chile (2004), Brazil (2004), Algeria (2006), Saudi Arabia (2007) and Latvia (2010).

${ }^{237}$ Algeria (2001), Malaysia (2001), Slovenia (2003), Sudan (2003), Armenia (2003), Hungary (2003), Uganda (2004), Saudi Arabia (2006), Serbia and Montenegro (2006), Kuwait (2006), Botswana (2006), Mexico (2007), Iceland (2007), Myanmar (2008), Luxembourg (2008), Syria (2008), Tajikistan (2008), Finland (2010), and Norway (2011).

${ }^{238}$ Qatar (2001), Cuba (2001), Venezuela (2001), Nepal (2001), Kazakhstan (2001), Indonesia (2001), Oman (2002), Nigeria (2002), Tunisia (2002), Iran (2002), Bahrain (2002), Greece (2002), Kyrgyzstan (2002), Morocco (2002), Sri Lanka (2003), Trinidad y Tobago (2003), Macau (2003), Brunei (2004), Albania (2004), Azerbaijan (2005), Georgia (2005), Mexico (2005), Saudi Arabia (2006), Hong Kong (2006), Algeria (2006), Singapore (2007), Taijikistan (2008), Ethiopia (2009), Czech Republic (2009), Belgium (2009), Turkmenistan (2009), Finland (2010), Zambia (2010), Malta (2010), Syria (2010), and United Kingdom (2010).
} 
majority of the cases, they act as capital exporter countries instead of as capital importer countries, which is usually the case for developing or less developed countries.

In 2013 the International Monetary Fund released an interesting article that can be used as an example of the matter. ${ }^{239}$ The article stated that of the countries that had until then signed DTCs with BRIC countries (since 2001), only Israel, Singapore, Estonia, Slovenia, Iceland, Luxembourg, Finland, Norway, the United Kingdom, the Czech Republic and Belgium could be considered as developed countries. Considering the 76 DTCs that were concluded by the BRIC countries from 2001 to 2013, only 13 (17\%) were signed with developed countries and the remaining $63(83 \%)$ were concluded with developing or less developed countries. Country by country, the percentages do not change dramatically. For Brazil, out of the nine DTCs that have been concluded since 2001, only one was signed with a developed country: Brazil-Israel (2002), or $11 \%$ of their new treaties. For Russia, out of the 12 DTCs concluded since 2001, only two were signed with developed countries: Russia-Singapore (2003) and Russia-Estonia (2002), or $16.6 \%$ of their new treaties. For India, out of the 19 DTCs that have been concluded since 2001, only five were signed with a developed country: IndiaSlovenia (2003), India-Iceland (2007), India-Luxembourg (2008), India-Finland (2010) and India-Norway (2011), or $26.3 \%$ of their new treaties. And lastly, for China, out of the 36 DTCs that have been concluded since 2001, only five were signed with a developed country: China-Singapore (2007), China-Czech Republic (2009), China-Belgium (2009), ChinaFinland (2010) and China-United Kingdom (2010), or 13.8\% of their new treaties.

This highlights the importance of developing or less developed economies for BRIC countries, countries with which they act as capital exporter countries and therefore became interested, from a revenue perspective, in reducing taxation at source and increasing taxation at residence. They act with the same interests as developed countries when signing a DTC with a developing country. As Monica Inés Hernández Gómez concluded in her research entitled: "The BRICs: Tax Treaty Policy Regarding Dividends", from a tax policy perspective, what BRIC countries have negotiated in the last decade demonstrates that China

\footnotetext{
${ }^{239}$ International Monetary Fund. World Economic and Financial Survey. World Economic Outlook Database, 2013. Available at: http://www.imf.org/external/pubs/ft/weo/2013/01/pdf/text.pdf
} 
is behaving as a capital exporter country - it provides incentives and encourages its residents to invest abroad - while Russia and India appear to be somewhere in the middle. In particular, India is leaning towards China's position and the government has expressly stated its interest in encouraging Indian companies to invest abroad. ${ }^{240}$ Brazil still adheres rather closely to the UN MTC by applying the highest withholding taxes of the four countries in their DTCs. These differences are probably the result of the different stages of development of each of the BRIC countries, which are in the process of becoming capital exporting countries.

In all of its treaties - since 2001 - Brazil uses a $10 \%$ withholding tax rate on FDI, which is higher than the $5 \%$ that is proposed by the OECD MTC; Russia uses a $5 \%$ or a $10 \%$ rate depending on the DTC, normally having higher withholding taxes in DTCs with South American countries (Argentina and Venezuela). India uses a 5\% rate and it is only in the DTC with Botswana that it uses a 7.5\% rate. China uses a 5\% rate in all their DTCs, which matches the OECD Proposal.

Thus, contrary to BRIC countries' policy regarding the treatment of active income, where the extent of the definition of permanent establishment or the new and strict source approaches regarding transfer pricing rules, the treatment of passive investment income in DTCs has a tendency to depart from a strict source approach. The tendency of lowering withholding taxes at source by BRIC countries can be seen as a strategic international policy move of these countries with the ultimate aim of increasing foreign investment and, consequently, to further development.

\subsection{UN MTC TREATMENT OF ACTIVE AND PASSIVE INVESTMENT INCOME}

As has been demonstrated, the distinction between passive investment income and active income in the international tax context has its origins in a 1923 report that was prepared by

\footnotetext{
${ }^{240}$ Hernández Gómez, Mónica Inés. The BRICs: Tax Treaty Policy Regarding Dividends. IBFD, Bulletin for International Taxation, Vol 66, 2012.
} 
the four economists of the League of Nations, ${ }^{241}$ the 1925 report of Technical Experts ${ }^{242}$ and the 1928 League of Nations Models. The choice by the Technical Experts to opt for the classification and assignment method as the most suitable method to determine the design of DTCs and to solve the problem of double taxation ${ }^{243}$ meant that the future of the treatment of passive investment income and active income in DTCs was fixed. The four economists chose the economic allegiance theory as they believed that this was the only theory that, alongside the ability to pay principle, was able to solve the problem of where a person ought to be taxed and how the division ought to be made between the treaty partners. ${ }^{244}$

The classification of active and passive investment income through the classification and assignment method that is currently in force in the UN MTC stems from the OECD MTC approach, and, therefore, from the LN approach. That approach is founded on the assumption that treaty partners are more or less similar regarding their development status, and thus can generate similar investments flows. The economic classification and assignment approach chosen by the LN and thereafter by the OECD lowered the risk of generating an unfair shift of tax revenue from one country to another. It was on this belief that the LN experts produced their work and, therefore, the criteria concluded are not suitable in the context of a DTC between a developing and a developed country. ${ }^{245}$

MTCs do not expressly refer to the concepts of active and passive income. The UN MTC, by following the OECD MTC, consolidates the idea of granting preferential rights to tax active income to source countries through the application of concepts such as: (1) permanent establishment; (2) residence; and (3) fixed base, amongst others. On the contrary, it also

${ }^{241}$ League of Nations, Economic and Financial Commission, Professors Bruins, Einaudi, Seligman, and Sir Josiah Stamp. Report on Double Taxation submitted to the Financial Committee, 1923. Available at: http://www.taxtreatieshistory.org/

${ }^{242}$ League of Nations, Technical Experts to the Economic and Financial Committee. Double Taxation and Tax Evasion. Report and Resolutions submitted by the Technical Experts to the Financial Committee, 1925. Available at: http://www.taxtreatieshistory.org/

${ }^{243} \mathrm{Ibid}, 243$.

${ }^{244}$ League of Nations, Economic and Financial Commission, Professors Bruins, Einaudi, Seligman, and Sir Josiah Stamp. Report on Double Taxation submitted to the Financial Committee. April, 1923. Available at: http://www.taxtreatieshistory.org/

${ }^{245}$ Van der Bruggen. Citing for the OECD quote, OECD Report on Fiscal Incentives for Private Investment in Developing Countries (1965), British Tax Review 119, 2002. 
consolidates the idea of granting preferential rights to tax passive investments income to residence countries. The principles governing the taxation of passive investment income and of active income in the DTC context have, however, been developed by the OECD. Probably the best example of this is the concept of permanent establishment.

The taxation of passive investment income, not only in the UN MTC but also in the OECD MTC, is based on the application of reciprocity: "Reciprocal reduction of withholding tax rates by source countries". This principle could cause unfairness when developing (or underdeveloped) countries are involved, as is illustrated in the example given by Charles R. Irish in his publication entitled: "International Double Taxation Agreements and Income Taxation at source". In this example, he states that in 1972, interest payments remitted from Zambia to private lenders domiciled in United Kingdom, the United States, West Germany and Japan were estimated to be in excess of US\$ 20 million per year, while interest payments from those countries to Zambian lenders were estimated to be less than US\$10,000 per year. $^{246}$

The UN MTC classification and allocation approach addresses the following incomes: (1) income from immovable property (Article 6); (2) business profits (Article 7); (3) shipping, inland waterways transport and air transport (Article 8); (4) associated enterprises (Article 9); (5) dividends (Article 10); (6) interest (Article 11); (7) royalties (Article 12); (8) fees for technical services (Article 12A); (9) capital gains (Article 13); (10) independent personal services (Article 14); (11) dependent personal services (Article 15); (12) director's fees and remuneration of top-level managerial officials (Article 16); (13) artists and sports persons (Article17); (14) pensions and social security payments (Article 18); (15) government services (Article 19); (16) students (Article 20); and (17) other income (Article 21). Incomes treated in Articles 6, 7, 8 number 1, 9, 15, 16, 17 and 18 are mostly allocated to the source country, and incomes from Article 8 number 2, 10, 11, 12, 12 A and 13 are mostly allocated to home / resident countries.

\footnotetext{
246 The information was obtained from the 1972 annual reports of Nchanga Consolidated Copper Mines Ltd. and Roan Consolidated Mines Ltd., the two major mining companies in Zambia and major remitters of interest abroad.
} 
In order to illustrate what has been described above, the following tables summarize the income classification and corresponding allocation of taxing rights that is currently used in the UN MTC regarding traditionally known active and passive investment income.

\begin{tabular}{|c|c|c|}
\hline Traditionally known Active Income & Allocation of taxing rights & $\begin{array}{c}\text { Elimination of Double } \\
\text { Taxation }\end{array}$ \\
\hline Art. 7: Business Income & $\begin{array}{l}\text { Source country unlimited rights (must fulfil some } \\
\text { criteria - permanent establishment) } \\
\text { Residence country only residual rights or unlimited if } \\
\text { source criteria is not fulfilled. }\end{array}$ & Credit or Exemption \\
\hline $\begin{array}{l}\text { Art. } 8 \text { (B): Shipping, Inland Waterways } \\
\text { Transport and Air Transport }\end{array}$ & $\begin{array}{l}\text { 1.- Income from the operation of ships: } \\
\text { Source country unlimited rights (must fulfil some } \\
\text { criteria - "more than casual"). Residence country only } \\
\text { residual rights or unlimited if source criteria is not } \\
\text { fulfilled. } \\
\text { 2.- Income from the operation of aircraft: } \\
\text { Residence country unlimited rights (where the effective } \\
\text { management of the enterprise is situated). }\end{array}$ & Credit or Exemption \\
\hline Art. 14: Independent personal services & $\begin{array}{l}\text { Source country unlimited rights (must fulfil some } \\
\text { criteria - fixed base or residency). Residence country } \\
\text { only residual rights or unlimited if criteria is not } \\
\text { fulfilled. }\end{array}$ & Credit or Exemption \\
\hline$\underline{\text { Art. 15: Dependent personal services }}$ & $\begin{array}{l}\text { Source country unlimited rights (previous fulfil some } \\
\text { criteria - residency, who paid the salary, and } \\
\text { remuneration is not borne by a permanent establishment } \\
\text { or a fixed base). Residence country only residual rights } \\
\text { or unlimited if criteria is not fulfilled. }\end{array}$ & Credit or Exemption \\
\hline $\begin{array}{l}\text { Art. } 16: \text { Director's fees and } \\
\text { remuneration of top-level managerial } \\
\text { officials }\end{array}$ & $\begin{array}{l}\text { Source country unlimited rights (country where the } \\
\text { company is resident). Residence country only residual } \\
\text { rights. }\end{array}$ & Credit or Exemption \\
\hline Art. 17: Artists and Sportspersons & $\begin{array}{l}\text { Source country unlimited rights (country where the } \\
\text { activities of the entertainer or sportsperson are } \\
\text { exercised). Residence country only residual rights. }\end{array}$ & Credit or Exemption \\
\hline
\end{tabular}




\begin{tabular}{|l|l|l|}
\hline Art. 18 (B): Pensions and Social & $\begin{array}{l}\text { Article 8 (B) is preferred by developing countries. } \\
\text { 1.- Payments made within framework of a public } \\
\text { scheme part of the social security system: } \\
\text { Source country unlimited rights (country from where is } \\
\text { the public scheme- social security system). Residence } \\
\text { country only residual rights. }\end{array}$ \\
$\begin{array}{l}\text { 2.- Payments not made within framework of a public } \\
\text { scheme part of the social security system: }\end{array}$ & $\begin{array}{l}\text { Source country unlimited rights (previous fulfil some } \\
\text { criteria - the payment is made by a resident or a } \\
\text { permanent establishment of the country where the } \\
\text { employment or services was performed). Residence } \\
\text { country only has residual rights or unlimited if criteria } \\
\text { are not fulfilled. }\end{array}$ \\
\hline
\end{tabular}

\begin{tabular}{|l|l|l|}
\hline \multicolumn{1}{|c|}{$\begin{array}{c}\text { Traditionally known Passive } \\
\text { Investment Income }\end{array}$} & \multicolumn{1}{|c|}{$\begin{array}{c}\text { Allocation of taxing rights } \\
\text { Double Taxation of }\end{array}$} \\
\hline$\underline{\text { Art. 10: Dividends }}$ & $\begin{array}{l}\text { Source country limited rights (country where the } \\
\text { company is situated). Residence country residual rights. }\end{array}$ & Credit \\
\hline$\underline{\text { Art. 11: Interest }}$ & $\begin{array}{l}\text { Source country limited rights (country where the } \\
\text { company is situated). Residence country residual rights. }\end{array}$ & Credit \\
\hline$\underline{\text { Art. 12: Royalties }}$ & $\begin{array}{l}\text { Source country limited rights (must fulfil some criteria - } \\
\text { beneficial owner residency). Residence country residual } \\
\text { rights or unlimited if criteria is not fulfilled. }\end{array}$ & Credit \\
\hline$\underline{\text { Art. 12 A: Fees for Technical Services }}$ & $\begin{array}{l}\text { Source country limited rights (must fulfil some criteria - } \\
\text { beneficial owner residency). Residence country residual } \\
\text { rights or unlimited if criteria is not fulfilled. }\end{array}$ & Credit \\
\hline
\end{tabular}

Both tables demonstrate the differences in intensity of how active and passive investment incomes are treated in the UN MTC. The treatment is definitely more accurate regarding the taxation of active income by prioritizing the economic allegiance analysis and legal development of principles with the view to allocating taxing rights fairly.

The comparison between the tax treatment of active and passive income in the UN MTC and in the OECD MTC has been successfully conducted by Michael Lennard in his publication entitled: "The UN Model Tax Convention as Compared with the OECD Model Tax 
Convention - Current Points of Difference and Recent Developments". This publication states the following:

(1) Article 5 paragraph 3(a) of the UN MTC has a six-month duration test for building sites compared to the 12-month duration that is required by the OECD MTC;

(2) Article 5 paragraph 3(b) of the UN MTC addresses the "services permanent establishments", which differs substantially from the OECD approach of treating services in the same way as the provision of goods;

(3) Article 5 paragraph 4(a) and (b) of the UN MTC omitted the concept of "delivery" from the list of preparatory and auxiliary activities by stating that "delivery" can constitute a sufficient economic nexus to the source. This is a completely different approach from the one used by the OECD in its comprehensive and clear comparison of the two models;

(4) Article 5 paragraph 5(b) of the UN MTC states that an agent that holds stock, even though that agent does not conclude contracts for the principal, can constitute a sufficient economic nexus to the host country and, therefore, a permanent establishment, so as to justify taxation by the host country;

(5) Article 5 paragraph 6 of the UN MTC states that where an insurance enterprise collects premiums in the territory of the other state or insures risks situated therein through a person that cannot conclude contracts and other than an agent of an independent status to whom paragraph 7 applies, this can constitute a deemed permanent establishment;

(6) Article 7 paragraph 1 of the UN MTC states the "force of attraction rule", which allows taxation by the source country of certain profits that are not actually attributable under normal rules to the permanent establishment: sales of similar goods or merchandise as well as other business activities of the same or a similar kind; 
(7) Article 7 paragraph 3 of the UN MTC provides some extra clarification of the treatment of deductions in determining permanent establishment profits;

(8) Article 8 of the UN MTC provides an alternative Article (b) regarding the taxation of profits from the operation of ships and aircraft in international traffic by granting limited instead of no rights to the source country in relation to this income, thereby departing from the OECD approach of no taxation at source;

(9) Article 10 paragraph 2 does not specify the maximum dividend withholding tax rate that is allowed to the source country and it has left this subject to negotiations between prospective treaty partners;

(10) Article 11 paragraph 2 does not specify the maximum interest withholding tax rate that is allowed to the source country and it has left this subject to negotiation between prospective treaty partners;

(11) Article 12 provides for source country taxation of royalties by granting limited instead of no source country rights in relation to this kind of income, as the OECD MTC does;

(12) Article 12 A provides for source country taxation of fees for technical services by granting limited instead of no source country rights in relation to this kind of income (without permanent establishment), as the OECD MTC does;

(13) Article 13 paragraph 4 of the UN MTC covers not only source country taxation of sales of shares in land-rich companies, but also interests in partnerships, trusts or estates. Also, and by extending source country rights, the UN MTC deals with the alienation of the shares of non-land-rich companies in a provision that does not appear in the OECD MTC;

(14) The UN MTC retains Article 14 which was deleted from the OECD MTC. However, it states an available alternative for those wishing to delete it. Therefore, the UN MTC keeps 
the "fixed base" test instead of replacing it by the permanent establishment test and business profit attribution, as is the case in the OECD MTC;

(15) Article 16 paragraph 2 extends the scope of this Article by including salaries, wages and other similar remuneration of "high level managers" as income that is to be taxed by the source state, the country where the company is resident; and

(16) Article 18 of the UN MTC provides for two alternatives. The first, following the OECD MTC approach, assigns to the country of residence the exclusive right to tax pensions and other similar remuneration. However, and as an important difference with the OECD MTC approach, it grants to the source country of the pension the exclusive right to tax when the payments involved are made within the framework of a public scheme which is part of the social security system of that country or a political subdivision or a local authority thereof. The second alternative provides for the sharing of taxing rights between the country of residence and the country of source of the pension regarding pensions and other similar remuneration when the payments involved are not made within the framework of a public scheme which is part of the social security system of a country or a political subdivision or a local authority thereof. If the payments are made within the framework of such a public scheme, the right to tax belongs only to the source country.

This list reinforces the statement regarding the depth of analysis and study of the treatment of active income, i.e. permanent establishment, business income, income from operations of ships and aircraft in international traffic, independent personal services, residency, fixed base test, director's fees and pensions, especially when compared to the analysis and study that has been done regarding passive investments income. From Lennard's publication, it is possible to conclude that the main focus of the UN MTC is related to the idea of reinforcing and extending the source country's taxation rights in DTCs between developing and developed countries. Properly determining the benefits that signatory countries should gain by concluding a DTC between a developing and a developed country is therefore something which has been neglected thus far. The UN MTC approach to royalty income is one clear example of this. 
Notwithstanding that it seems that the UN MTC does not achieve the goal of fairly dividing the right to tax between source and residence countries, it is possible to observe that the UN MTC has developed its approach and, therefore, it has achieved fair and accurate results regarding active incomes. What can be said with regard to known active income cannot be said with regard to the treatment of passive investment income, where there has been no salient development of consistent principles.

The UN MTC, by following the OECD MTC approach regarding the classification of income, failed due to the different economic realities of the potential treaty partners. The design of the articles governing the taxation of passive investment income assumes that dichotomies in allocation will be solved by the existence of reciprocal investment flows. The non-reciprocity of investments therefore highlights the problem of that MTC. When contracting states are at vastly different levels of economic development, the income flows are substantially unilateral: out of the developing country, as the source country, and into the developed country, as the residence country. ${ }^{247}$

This research considers that the classification of the income as active or passive in the UN MTC - due to the desired or undesired influence of the OECD MTC in its design - is the greatest obstacle for developing countries when analysing the benefits of a DTC with a developed country. The decision made by the UN, i.e. a lack of analysis of the benefits carried out by the division of taxing rights regarding passive investment income, has forced developing countries to restrict their demands only to the ineffective claim of higher withholding taxes at source, thereby distorting the real sense behind the decision of developing countries as to whether to sign a DTC with a developed country. The development of the model has been influenced by these demands, instead of by setting proper rules that provide incentives for the increase of foreign investment in the source country.

\footnotetext{
${ }^{247}$ Irish, Charles R. International Double Taxation Agreements and Income Taxation. The International and Comparative Law Quarterly, Vol 23, 1974.
} 


\section{PART II - HISTORY TO DATE}

The history, validating all of the foregoing, demonstrates that developing countries have focused their efforts on claiming more taxing rights when signing DTCs with developed countries. The position of developing countries regarding the allocation of taxing rights ${ }^{248}$ in DTCs with more developed countries only became a discussion point after the Second World War, ${ }^{249} 250251$ and these claims were expressed in the creation of the MTCs. ${ }^{252}$

\subsection{DEVELOPING COUNTRIES' CLAIMS OF TAXING RIGHTS - MTC CONTEXT}

\subsubsection{MEXICO MODEL}

The first joint action by developing countries was embodied in the Mexico MTC. In June 1939, the Fiscal Committee of the League of Nations suggested that the 1928 Geneva Models dealing with direct taxes should be revised in light of the technical improvements embodied in the various bilateral DTCs that were concluded during the 1930s. ${ }^{253}$ The Fiscal Committee met in The Hague in April 1940, but this work was abandoned on 10 May 1940 after the city of Rotterdam was bombed during the Second World War.

\footnotetext{
${ }^{248}$ Pickering, Ariane. Why Negotiate Tax Treaties?. Papers on Selected Topics in Negotiation of Tax Treaties for Developing Countries, United Nations, 2013. Available at: http://www.un.org/esa/ffd/wpcontent/uploads/2013/05/20130530_Paper1N_Pickering.pdf.

${ }^{249}$ Arnolds, Brian J. An introduction to tax treaties, 2015. Available at: http://www.un.org/esa/ffd/wpcontent/uploads/2015/10/TT_Introduction_Eng.pdf

${ }^{250}$ Daurer, Veronica; and Krever, Richard. Choosing between the UN and the OECD Tax Policy Models: an African Case Study. European University Institute, Florence: Robert Schuman Centre for Advanced Studies. Working Paper RSCAS 2012/60.

${ }^{251}$ Lang, Michael. Introduction to the Law of Double Taxation Conventions, $2^{\text {nd }}$ ed. Linde, 2010. p. 32.

252 League of Nations, Model Bilateral Convention for the Prevention of the Double Taxation of Income (Mexico Model), 1943; Andean Community, Decision 40 (MTC - Cartagena Agreement), 1971; and United Nations, Department of Economic and Social Affairs, Model Double Taxation Convention between Developed and Developing Countries, 2017.

253 United Nations, Department of Economic and Social Affairs, Division for Public Administration and Development Management, Manual for the Negotiation of Bilateral Tax Treaties between Developed and Developing Countries, 2003.
} 
Due to the political conflict that characterized this period of European history, the Director of the League of Nations' Financial Division and the Secretary of the Fiscal Committee left Geneva. Both went to Princeton University in the United States of America to continue their research. ${ }^{254}$ Mitchell B. Carroll, who was the Chairman of the Committee, arranged with the Mexican member of the Fiscal Committee to hold a Regional Tax Conference with representatives of Canada, the United States of America, Mexico and other Latin American countries. $^{255}$

Two conferences were held under the auspices of the League of Nations, the first in June 1940 and the second in July 1943. During the first conference, the model was prepared together with a variety of documents submitted by the Secretariat of the League of Nations. ${ }^{256}$ During the second conference, the MTC that was adopted replaced the 1928 Geneva Model.

Regarding passive investment income, the Mexico MTC granted host / source countries preferential taxing rights on interest and dividend income - in Article 9 thereof ${ }^{257}$ - and royalty income - in Article 10 thereof. $^{258}$ As regards the source of dividends and interest, the MTC followed a strict host country approach, i.e. the source of the income was always associated with the country where the capital was invested. With respect to the source of royalties, the MTC distinguished between the rights on industrial works (patents, secret processes or formulas, trademarks and analogous rights) and cultural works, stating that royalty income derived from the former must be taxed by the country where such rights were

\footnotetext{
${ }^{254}$ Carrol, Mitchell B. Benefits for American Investors and Enterprises Abroad: Part 1. International Tax Law, Vol 2, 1968.

255 The conference was attended by representatives of Argentina, Bolivia, Canada, Chile, Colombia, Ecuador, Mexico, Peru, United States of America, Uruguay and Venezuela.

${ }^{256}$ United Nations, Department of Economic and Social Affairs, Division for Public Administration and Development Management, Manual for the Negotiation of Bilateral Tax Treaties between Developed and Developing Countries, 2003.

257 League of Nations, Model Bilateral Convention for the Prevention of the Double Taxation of Income (Mexico Model), 1943, Article 9: "Income from movable capital shall be taxable only in the contracting State where such capital is invested."

${ }^{258}$ Ibid, 258, Article 10. "1. Royalties from immovable property or in respect of the operation of a mine, a quarry, or other natural resource shall be taxable only in the contracting State in which such property, mine, quarry, or other natural resource is situated. 2. Royalties and amounts received as a consideration for the right to use a patent, a secret process or formula, a trade-mark or other analogous right shall be taxable only in the State where such right is exploited. 3. Royalties derived from one of the contracting States by an individual, corporation or other entity of the other contracting State, in consideration for the right to use a musical, artistic, literary, scientific or other cultural work or publication shall not be taxable in the former State."
} 
exploited. The latter, however, were exempted from taxation at the state where they were exploited. This way, the MTC recognized some source connection with the country where the royalty was most likely developed, i.e. the residence country of the licensee. ${ }^{259}$

The new MTC represented the position of developing countries at that time regarding the allocation of taxing rights in DTCs between developing and developed countries. That position, justified at that time as a reaction to the strict residence base approach of the LN MTC, was not based on development but rather on the amount of taxing rights / collection of taxes.

In the Mexico MTC, the allocation of taxing rights approach was the consequence of the application of the "economic classification and assignment approach". The economic interest of the taxpayer was interpreted on the basis of developing countries' interests, demonstrating that the economic link required between the income and the countries could be interpreted in more than one way, i.e. the main problem of this method of allocating taxing rights. In this Model, developing countries - typically host / source countries in commercial relations with developed countries - had the opportunity to jointly express their position. ${ }^{260}$

At that time, DTCs did not replicate what was provided for in domestic law. The domestic laws of developed countries were not as developed as they are today. This means that DTCs, by eliminating double taxation, were real drivers for facilitating investment in the host country. The elimination of double taxation was only based on the exemption system. As in the League of Nations Models, the Mexico MTC allocated taxing rights to one of the two contracting countries, departing from what the OECD MTC and the UN MTC currently does today. Notwithstanding that the United States of America and the United Kingdom were already using a unilateral credit at domestic level to eliminate double taxation, this was not yet a reality at DTC level.

\footnotetext{
${ }^{259}$ Ibid, 258, Article 10. "3. Royalties derived from one of the contracting States by an individual, corporation or other entity of the other contracting State, in consideration for the right to use a musical, artistic, literary, scientific or other cultural work or publication shall not be taxable in the former State."

${ }^{260}$ That position found doctrinal support in the conferences I, IV, VI and VII of the Latin American Institute of Fiscal Law - Instituto Latinoamericano de Derecho Tributario- held in Montevideo (1956), Buenos Aires (1964), Punta Del Este (1970) and Caracas (1975) respectively.
} 
It was therefore an historical circumstance that allowed developing countries to state their position regarding the design of a DTC, taking their needs into account while agreeing to restrict their sovereignty in relation to taxing income at source. At the Manila Conference on the Law of the World in August 1977, the Mexico MTC was considered to be "the first attempt by the developing countries to write a model treaty reflecting their particular problems". ${ }^{261}$

\subsubsection{DECISION 40 OF THE ANDEAN COMMUNITY}

31 years later, in 1971, the Andean Community ${ }^{262}$ - known as Andean Pact until 1969 released two MTCs through "Decision 40". ${ }^{263}$ One of these MTCs regulates treaties between member states of the Andean Community while the other intends to regulate treaties between member countries of the Andean Community and third countries.

This MTC, which is comparable to the Mexico MTC, was also designed by starting from a particular and independent interpretation of the location of the economic interest of the taxpayer. Regarding the economic classification and assignment approach, this MTC also used an approach that left most of the taxing rights to the country where the capital was invested, where the borrowed money was used, or where the royalties were exploited. For the members of the Andean Community, the connecting factor - the economic link - between passive investment income and the country was coincidently always in the host / source country and never in the home / residence country.

\footnotetext{
261 Ibid, 261.

${ }^{262}$ Information available at: http://www.comunidadandina.org

${ }^{263}$ Agreement available at: http://www.sice.oas.org/trade/junac/decisiones/Dec040e.asp
} 
The Model granted exclusive taxing rights to the source country to tax passive investment income in Article 9 on royalties, ${ }^{264}$ in Article 10 on interest ${ }^{265}$ and in Article 11 on dividends. ${ }^{266}$ As was stated by Buitrago ${ }^{267}$ in her book entitled "El concepto de Cánones y/o Regalías en los Convenios para Evitar la doble Imposición sobre la Renta", the MTC, which intended to regulate the relations of Andean Member States with third countries, was never actually used by the Andean member countries. ${ }^{268}$ Instead, the majority of the countries' treaty networks were unsatisfactory or non-existent, and this was only rectified a few years ago. However, for Community purposes, the criteria are still in force and in 2004 they were even sharpened. In 2004 the Andean Community released a new provision, the "Decision $578 ", 269$ so as to avoid double taxation and prevent fiscal evasion within the Andean Community. This decision did not derogate from the MTC with third countries.

According to Decision 578, royalties on intangibles may be taxable only by the country in which the intangible is used or in which the right to use is granted. ${ }^{270}$ However, business profits related to the performance of services, technical services, technical assistance and consultancy may be taxable only in the member country in whose territory the benefit of such services occur. This is, unless demonstrated otherwise, the country in which the benefit is charged and registered. Interest and other financial income are taxable only by the member country which charges and registers the payment. ${ }^{271}$ Dividends are taxable only by the member country in which the entity distributing the dividends is incorporated / domiciled. ${ }^{272}$

\footnotetext{
${ }^{264}$ Andean Community, Decision 40 (MTC - Cartagena Agreement), 1971, Article 9: “Royalties earned from the use of trademarks, patents, unpatented technical know-how or other intangible goods of a similar nature in the territory of one of the Contracting States shall be taxable only in that Contracting State."

265 Ibid, 265. Article 10: "Interest earned on loans shall be taxable only in the Contracting State where the loan funds were used. Unless proven otherwise, it is assumed that the loan shall be used in the Contracting State where the interest is paid."

${ }^{266}$ Ibid, 265. Article 11: "Dividends and equity investments shall be taxable only by the Contracting State where the enterprise distributing them has its legal residence."

${ }^{267}$ Buitrago Diaz, Esperanza. El Concepto de Cánones y/o Regalías en los Convenios para Evitar la Doble Imposición sobre la Renta, CISS-Kluwer, Spain, 2007, p. 371.

268 Ibid, 269.

${ }^{269}$ Decision 578 available at: http://www.sice.oas.org/trade/JUNAC/junaind.asp

${ }^{270}$ See Article 9: "Las regalías sobre un bien intangible sólo serán gravables en el País Miembro donde se use o se tenga el derecho de uso del bien intangible".

271 See Article 10: “Los intereses y demás rendimientos financieros sólo serán gravables en el País Miembro en cuyo territorio se impute y registre su pago".

272 See Article 11: "Los dividendos y participaciones sólo serán gravables por el País Miembro donde estuviere domiciliada la empresa que los distribuye. El País Miembro en donde está domiciliada la empresa o persona receptora o beneficiaria de los dividendos o participaciones, no podrá gravarlos en cabeza de la sociedad
} 
As in the case of the Mexico MTC, the early and brave attempt of the Andean Community can be seen as a reaction to the 1963 OECD MTC. It was a conscious decision from the Andean Community to promulgate an MTC that took not only the economic development of their members into consideration, but also the protectionism of national economies at that time. More importantly, the Andean Community seems to have followed the 1953 and 1969 recommendations of the Economic and Social Council of the United Nations ("Resolutions 486-B and 1430 respectively") ${ }^{273}$ so as to adopt the source as the criteria underpinning tax agreements between developed and developing countries. ${ }^{274}$ By doing so, the Andean countries became somewhat isolated, their treaty networks with third countries did not follow the intended approach, and later UN works have not had the strength to support that approach. Nowadays the Andean member countries do not exhibit a unified position in this field. Venezuela, which has the biggest treaty network, left the community in 2006 and Colombia already joined the OECD. However, their respective treaty networks show more adherence to the UN approach on the taxation of passive income compared to the OECD approach.

\subsubsection{UN MODEL TAX CONVENTION}

After the publication of the 1963 OECD Draft MTC, and later the 1977 OECD MTC, the OECD MTC quickly became the worldwide standard for the purposes of tax treaty negotiations. ${ }^{275}$ Until 1965, only a few treaties were concluded between developed and developing countries. The OECD Fiscal Committee acknowledged this in its 1965 Report, which was completed in Paris, stating that: "(...) the traditional tax conventions have not commended themselves to developing countries". ${ }^{276}$ The lack of DTCs in force, the increase

\footnotetext{
receptora o inversionista, ni tampoco en cabeza de quienes a su vez sean accionistas o socios de la empresa receptora o inversionista”.

${ }^{273}$ ECOSOC: Resolution 486-B from the $9^{\text {th }}$ of July of 1953 . Ratified by the resolution 1430 from the $6^{\text {th }}$ of June of 1969.

${ }^{274}$ Ibid, 269.

${ }^{275}$ Kosters, Bart. The United Nations Model Tax Convention and its Recent Developments. IBFD, Asia-Pacific Tax Bulletin, Vol 10, 2004.

276 OECD, Fiscal Incentives for Private Investment in developing Countries: Report of the OECD Fiscal Committee, 1965. para. 164.
} 
of international trade and the end of colonialism were key factors that determined the need for guidelines for the negotiation and conclusion of DTCs between developing and developed countries. As Bart Koster stated in his publication "The United Nations Model Tax Convention and its Recent Developments", 277 there was a consensus that the OECD MTC was more appropriate for negotiations between developed countries and less suitable for capital importing countries or developing countries. The pressure was put on the United Nations to reassume the work done by the League of Nations. The United Nations reacted by setting up an independent working group (Ad Hoc Group of Experts on Tax Treaties between Developed and Developing Countries) of DTC experts that were appointed by their governments but who acted in their personal capacity. The UN Secretary General created the group in 1968 by complying with Resolution number 1273 of the ECOSOC, which was adopted on 4 August $1967 .{ }^{278}$

The Ad Hoc Expert Group was formed by representatives from countries in Latin America, North America, Africa, Asia and Europe, and it also included observers from the International Monetary Fund, the International Fiscal Association, the OECD, the International Bureau of Fiscal Documentation and other international organizations. ${ }^{279}$ The first step for this group was the formulation, over the course of the seven meetings from 1968 to 1977 , of the guidelines for the negotiation of bilateral DTCs between developed and

\footnotetext{
277 Bart Kosters. The United Nations Model Tax Convention and its Recent Developments. IBFD Asia-Pacific Tax Bulletin, Vol 10, 2004.

${ }^{278}$ United Nations, Economic and Social Council, Resolution 1273, 1967: "set up an ad hoc working group consisting of experts and tax administrators nominated by Governments, but acting in their personal capacity, both from developed and developing countries and adequately representing different regions and tax systems, with the task of exploring, in consultation with interested international agencies, ways and means for facilitating the conclusion of tax treaties between developed and developing countries, including the formulation, as appropriate, of possible guidelines and techniques for use in such tax treaties which would be acceptable to both groups of countries and would fully safeguard their respective revenue interests."

279 The seven meetings of the Ad Hoc Group of Experts, from 1968 to 1977, were attended by members of: Argentina, Brazil, Chile, France, Federal Republic of Germany, Ghana, India, Israel, Japan, the Netherlands, Norway, Pakistan, the Philippines, Sri Lanka, the Sudan, Switzerland, Tunisia, Turkey, the United Kingdom of Great Britain and Northern Ireland and the United States of America. These meetings were also attended by the observers from Austria, Belgium, Finland, the Republic of Korea, Mexico, Nigeria, Spain, Swaziland and Venezuela and from the following international organizations: the International Monetary Fund, the International Fiscal Association, the OECD, the Organization of American States and the International Chamber of Commerce.
} 
developing countries, which were contained in the "Manual for the Negotiation of Bilateral Tax Treaties between Developed and Developing Countries". 280

In the first regular ECOSOC session on the work of the Group of Experts, the Secretary General expressed the view that "(...) the completion of a model bilateral convention for possible use by developed and developing countries constitutes a logical follow-up to the work done by the Group of Experts relating to the formulation of guidelines".

The UN MTC was published in 1980. This was the third attempt of developing countries to set up an MTC that represented their views. The approach regarding the allocation of taxing rights was inherited from the 1928 Geneva Models. The UN MTC Model, unlike the Mexico MTC and Decision 40 of the Andean Community regarding the relation of its Member States with third countries, achieved more worldwide consensus on the demands of developing countries in relation to an MTC that was to be designed for the negotiation and conclusion of DTCs between developed and developing countries. Regarding passive investment income, the 1980 UN MTC took as a starting point the 1963-1977 OECD MTC approach, i.e. an approach of sharing taxing rights between host / source and home / residence countries by limiting taxation at source.

The UN MTC followed the OECD MTC regarding the methods to eliminate double taxation. Paragraph 2 of Article 23 A and Article 23 B of the 1980 UN MTC ratified the credit method as the method to avoid double taxation regarding passive investment income. In so doing, the UN MTC limited the discussion regarding the fair demands of developing countries (host / source states) in DTCs with developed countries to only the question of whether or not to increase withholding taxes at source. At that time, the number of OECD / developed countries that used a participation exemption was not as high as it is today. Thus, a worldwide system of taxation / credit system was still being used in the domestic legislation of most developed countries. $^{281}$

2802019 version available at: https://www.un.org/esa/ffd/wp-content/uploads/2019/06/manual-bilateral-taxtreaties-update-2019.pdf

${ }^{281}$ Only 9 of the current 34 OECD countries used territorial systems in 1980. See PWC Report, Evolution of Territorial Tax Systems in the OECD, 2013. Available at: 
The UN MTC granted limited taxing rights to source countries regarding the taxation of passive investment income. For dividends, the Model granted taxing rights to the state of residence of the recipient of the income. ${ }^{282}$ However, and in a minor way, the Model allowed taxation at source, i.e. in the state in which the company paying the dividends was resident, but limited the right to tax of that state up to a percentage on the gross base - to be defined through bilateral negotiations - if the recipient was a company and the beneficial owner of the interest held at least $10 \%$ of the capital of the company paying dividends, stating that in all other cases the limit would be extended to another percentage-also to be defined through treaty negotiations. ${ }^{283}$

With respect to the taxation of interest income, the Model also followed a similar approach by granting taxing rights to the state of residence of the recipient of the income ${ }^{284}$ and by limiting the source state's right to tax, the limit of which was to be defined through bilateral negotiations on the gross amount of the interest when the recipient is the beneficial owner of the interest. $^{285}$

On the treatment of royalties, the 1980 UN MTC differed from the OECD 1963-1977 Models by allowing taxation by the state where the royalties arise and according to the laws of that

http://www.techceocouncil.org/clientuploads/reports/Report\%20on\%20Territorial\%20Tax\%20Systems_2013 0402b.pdf

${ }^{282}$ United Nations, Department of Economic and Social Affairs, Model Double Taxation Convention between Developed and Developing Countries, 1980, Article 10 paragraph 1: "Dividends paid by a company which is a resident of a Contracting State to a resident of the other Contracting State may be taxed in that other State." ${ }^{283} \mathrm{Ibid}$, Article 10 paragraph 2: "However, such dividends may also be taxed in the Contracting State of which the company paying the dividends is a resident and according to the laws of that State, but if the recipient is the beneficial owner of the dividends the tax so charged shall not exceed: (a) ___ per cent (the percentage is to be established through bilateral negotiations) of the gross amount of the dividends if the beneficial owner is a company (other than a partnership) which holds directly at least 10 per cent of the capital of the company paying the dividends; $(b) \ldots$ per cent (the percentage is to be established through bilateral negotiations) of the gross amount of the dividends in all other cases. The competent authorities of the Contracting States shall by mutual agreement settle the mode of application of these limitations. This paragraph shall not affect the taxation of the company in respect of the profits out of which the dividends are paid.".

${ }^{284}$ Ibid., 283. Article 11 paragraph 1: "Interest arising in a Contracting State and paid to a resident of the other Contracting State may be taxed in that other State.".

${ }^{285}$ Ibid, 283. Article 11 paragraph 2: "However, such interest may also be taxed in the Contracting State in which it arises and according to the laws of that State, but if the recipient is the beneficial owner of the interest the tax so charged shall not exceed ___ per cent (the percentage is to be established through bilateral negotiations) of the gross amount of the interest. The competent authorities of the Contracting States shall by mutual agreement settle the mode of application of this limitation.". 
state, ${ }^{286}$ thereby upholding the demands of developing countries. The MTC, however, follows the general criterion that "Royalties arising in a Contracting State and paid to a resident of the other Contracting State may be taxed in that other State".

Neither the Mexico MTC nor Decision 40 succeeded in practice. The UN MTC is the only Model that has regard to the demands of developing countries and which has actually been applied in practice. This success confirms one fundamental premise of this research: DTCs are bilateral contracts that must give rise to mutual benefits. The revenue perceived by developing countries according to the share of taxing rights over passive investment income in DTCs between developing and developed countries has probably been perceived by developing countries as one benefit of agreeing a DTC with a developed country.

To date, practice has demonstrated that the only viable solution to issues related to the allocation of taxing rights in DTCs between developing and developed countries is to share taxing rights. That is the difference between the Mexico MTC, Decision 40 and the UN MTC. The UN MTC seems to grant a minimum balance so as to make the MTC attractive for both contracting states. Could that be improved by facilitating foreign investments in developing countries?

\subsection{EXPERIENCES OF OTHER MTCS REGARDING TREATMENT OF PASSIVE INVESTMENT INCOME}

As previously mentioned, the first MTC only became a reality after the end of the First World War in 1919. After a request made by the International Chamber of Commerce (ICC), ${ }^{287}$

\footnotetext{
${ }^{286}$ Ibid, 283. Article 12 paragraph 1: "Royalties arising in a Contracting State and paid to a resident of the other Contracting State may be taxed in that other State"; and paragraph 2: "However, such royalties may also be taxed in the Contracting State in which they arise and according to the laws of that State, but if the recipient is the beneficial owner of the royalties, the tax so charged shall not exceed___ per cent (the percentage is to be established through bilateral negotiations) of the gross amount of the royalties. The competent authorities of the Contracting States shall by mutual agreement settle the mode of application of this limitation. ".

${ }^{287}$ International Chamber of Commerce, Resolution $\mathrm{N}^{\circ} 11$ of the Constituent Congress in 1920 referred to in: League of Nations, Technical Experts to the Economic and Financial Committee. Double Taxation and Tax Evasion. Report and Resolutions submitted by the Technical Experts to the Financial Committee, February 1925. Available at: http://www.taxtreatieshistory.org
} 
supported by the Report on Double Taxation published in March of 1923 by the four economists, ${ }^{288}$ plus the experience and expertise of the members of the Committee of Technical Experts on Double Taxation and Tax Evasion ${ }^{289}$ of the League of Nations, the General Meeting of Government Experts on Double Taxation and Tax Evasion, convened by the Council of the League of Nations, adopted a Bilateral Convention for the Prevention of Double Taxation in the Special Matter of Direct Taxes in October 1928, along with three other MTCs dealing with succession duties, administrative assistance in matters of taxation and judicial assistance in the collection of taxes respectively. ${ }^{290}$ All of these are known as the 1928 Geneva Models. ${ }^{291}$

The League of Nations was the predecessor to the United Nations and it was the main institution working in the field of international double taxation and Model DTCs until shortly after World War II.

\subsection{1 - MODEL TAX CONVENTION LEAGUE OF NATIONS 1928}

This first MTC was the result of almost a decade of work carried out by the Committee of Technical Experts ${ }^{292}$ in addition to the work that was conducted by the four economists that was consolidated in a report that was submitted in 1923 to the Financial Committee of the League of Nations. In 1927, a Draft Convention was held, which presupposed an income tax structure in the contracting parties consisting of impersonal taxes on specific categories of incomes with flat rates and a superimposed personal income tax with progressive rates on

\footnotetext{
288 Professor Bruins -The Netherlands-, Professor Einaudi -Italy, Professor Seligman - United States -, Sir Josiah Stamp - United Kingdom -.

${ }^{289}$ Ibid, 288.

290 United Nations, Department of Economic and Social Affairs, Division for Public Administration and Development Management, Manual for the Negotiation of Bilateral Tax Treaties between Developed and Developing Countries, New York, 2003.

${ }^{291}$ Bart Kosters. The United Nations Model Tax Convention and its Recent Developments. IBFD Asia-Pacific Tax Bulletin, Vol 10, 2004.

${ }^{292}$ League of Nations, Technical Experts to the Economic and Financial Committee. Double Taxation and Tax Evasion. Report and Resolutions submitted by the Technical Experts to the Financial Committee, February 1925. Available at: http://www.taxtreatieshistory.org/
} 
entire net income. ${ }^{293}$ However, and due to the fact that the Draft Convention could not fit in with the systems that were used in most of the countries represented in the League of Nations, two other MTCs were adopted as a response. Thus, the 1928 report contained three Model Conventions (MTCs): 1 A), 1 B) and 1 C).

This result was achieved by combining the work done by the four economists, work that examined the topic of double taxation from a theoretical and scientific perspective, and the work that was carried out by the committee of technical experts, which examined the topic from an administrative, technical and practical perspective. Thus, it is clear that the LN MTC was not a model based on pure economic theory. The MTCs - mainly the base model resulted in the combination of the economic allegiance theory that was proposed by the report of the four economists and the classification and assignment method that was chosen by the Committee of Technical Experts.

The nationalities of the members - the four economists ${ }^{294}$ and technical experts ${ }^{295}$ - were considered as being relevant to the criteria produced that underpinned both reports. ${ }^{296}$ This not only concerned their preference regarding the source or the residence principle on the allocation of taxing rights, but it also concerned the structure of the MTC, a structure that was definitively influenced by the tax systems of the most powerful countries at that time.

At the time of the four economists' report ${ }^{297}$ for the League of Nations in 1923, only the United Kingdom, the United States, Germany and the Netherlands (partly) were regarded as

\footnotetext{
${ }^{293}$ Carrol, Mitchell B. Benefits for American Investors and Enterprises Abroad: Part 1. International Tax Law, Vol 2, 1968.

${ }^{294}$ Professor Bruins -The Netherlands-, Professor Einaudi -Italy, Professor Seligman - United States -, Sir Josiah Stamp -United Kingdom -.

${ }^{295}$ League of Nations, Technical Experts to the Economic and Financial Committee. Double Taxation and Tax Evasion. Report and Resolutions submitted by the Technical Experts to the Financial Committee, February 1925.

${ }^{296}$ As Graetz and O'Hear have rightly observed that the principal authors of the Report of the Four Economists were from capital exporting creditor nations and their report reflected the interest of those nations. See Graetz, Michael J.; and O'Hear, Michael M. The 'Original Intent' of U.S. International Taxation. Duke Law Journal, Vol 46, 1997.

${ }^{297}$ League of Nations, Economic and Financial Commission, Professors Bruins, Einaudi, Seligman, and Sir Josiah Stamp. Report on Double Taxation submitted to the Financial Committee, 1923.
} 
having personal income taxes. ${ }^{298}$ The report by the technical experts ${ }^{299}$ noted that the tax systems of most other European and American nations were based on impersonal taxes. ${ }^{300}$ 301 Nevertheless, the second report of the committee of technical experts - which clearly reflected the influence of the United States which joined the Committee in 1926 - produced the Draft Model Convention 1 A), which gave rights to the source countries to levy impersonal taxes, assigning source rules for each category of income and it also gave rights to the residence countries to levy personal tax. The right to levy personal tax was subject to the elimination of double taxation by the residence country by granting a foreign tax credit. ${ }^{302}$ This approach was opposed in practice, as was evidenced in the treaty between Italy and Czechoslovakia, ${ }^{303}$ which was examined by the Committee of Technical Experts and which assigned taxing rights in an exclusive way. ${ }^{304}$

The influence exerted by developed countries has naturally determined the future of DTCs. The League of Nations Model 1928 - Model 1A) - was the basis for the OECD MTC 1963 and therefore for the UN MTC 1980. The change of vision that was imposed by the Committee of Technical Experts, who were influenced by the taxation systems of the United Kingdom and the United States, changed how treaties were built, by analysing the nature of the income and the assignment of taxing rights, which resulted in an approach that was more focused on the tax systems of the treaty partners than on the potential economic effects for treaty partners. That approach omitted or simply diminished the importance of the analysis of the nature of the income - i.e. active or passive - in order to decide which country should have strongest rights to tax. However, the approach fulfilled the expectations of treaty partners regarding the division of tax revenue, without the need to differentiate between

\footnotetext{
298 Taylor, C. John. Twilight of the Neanderthals, or Are Bilateral Double Taxation Treaty Networks Sustainable?. Melbourne University Law Review, Vol 34, 2010.

${ }^{299}$ League of Nations, Technical Experts to the Economic and Financial Committee. Double Taxation and Tax Evasion. Report and Resolutions submitted by the Technical Experts to the Financial Committee, 1925.

${ }^{300}$ Impersonal Taxes: taxes on distinct categories of income (such as land, business profits, and so on). See Taylor, C. John. Twilight of the Neanderthals, or Are Bilateral Double Taxation Treaty Networks Sustainable?. Melbourne University Law Review, Vol 34, 2010.

${ }^{301}$ Ibid, 301.

302 Ibid, 301.

303 Treaty between Italy - Czechoslovakia for the Prevention of Double Taxation and the Settlement of other Questions concerning Direct Taxation, 1924. Final Protocol, signed 1 March 1925.

${ }^{304}$ The reduction in the tax base of the personal tax with the consequent effects on the applicable marginal rates that it involved would not have been acceptable to countries such as United Kingdom and United States, whose income taxes were confined to personal taxes levied on a worldwide basis.
} 
active and passive income so as to correctly allocate taxing rights. This, in practice, quelled many theoretical discussions and allowed the LN to present an MTC.

A broad qualification of income - leaving behind an accurate analysis of the nature of the income - and an assignment method based on the reciprocity of investments flows confined the taxation approach in relation to those incomes to what it is currently stated in the UN MTC. In addition, the existence of personal and impersonal taxes was considered to be the most important factor and, therefore, it granted the right to tax to the source country and to the residence country on different levels in relation to all passive investment incomes.

The MTC 1 A) of 1928 report was the "basic model", whereby the source country's right to tax passive investment income was a predominate feature of this model. As was stated, this MTC followed a schedular approach by distinguishing between impersonal taxes (i.e. "taxes (...) levied on all kinds of incomes at source, irrespective of the personal circumstances of the taxpayer") ${ }^{305}$ which must be collected by the state of source, ${ }^{306}$ and personal taxes (i.e. taxes "which rather concern individuals and their aggregate income") ${ }^{307}$ which must be collected by the state of residence. ${ }^{308}$ The necessary deductions to avoid double taxation had to be applied by the state of residence. ${ }^{309}$

The MTC preferably granted rights to the source countries regarding the taxation of passive investment income in the following articles: interest income in Article 3 and dividend income in Article 4. Regarding royalties, there was no specific article dealing with the matter, although in the draft on allocation of business income of 1935, the committee defined the source of mining royalties as the place where the mine is situated. ${ }^{310}$ The question about the

\footnotetext{
305 League of Nations, Model Tax Convention, No. 1 A, 1928, commentary on Article 1.

306 Wang, Ke Chin. International Double Taxation of Income: Relief Through International Agreement 1921 1945. Harvard Law Review, Vol 59, 1945.

${ }^{307}$ League of Nations, Model Tax Convention, No. 1 A, 1928, commentary on article 1.

308 Ibid, 306.

309 Ibid. 306.

${ }^{310}$ League of Nations, Fiscal Committee. Report to the Council on the fifth session of the Committee, Annex I: Revised text of the Draft Convention for the allocation of business income between States for the purpose of taxation, Geneva, 1935. Available at:

http://www.uni-

heidelberg.de/institute/fak2/mussgnug/historyoftaxdocuments/normtexte/voelkerrecht/V00016.pdf.
} 
source of cross-border income derived from patent and copyright royalties was subsequently solved by the Fiscal Committee, which held that such items should be taxable at the fiscal domicile of the recipient, except when they constitute a part of the commercial income of an enterprise, in which case they would be taxable as part of the income of the establishment which exploited them. ${ }^{311}$

Regarding the taxation of dividends, the MTC provided a hybrid source-residence approach by stating that the: "(...) income from shares or similar interests shall be taxable in the State in which the real centre of management of the undertaking is situated". 312 This is a hybrid approach because the real centre of management of an undertaking is, by its very definition, a source rule but, in practice, it can end up being the country in which the undertaking is resident - the "source approach" - or the country in which the shareholders are resident - the "residence approach".

With respect to the taxation of interest, the Model clearly provides a source country approach by stating that: “(...) income from public funds, bonds, including mortgage bonds, loans and deposits or current accounts, shall be taxable in the State in which the debtors of such income are at the time resident". 313

The second MTC was presented as a "simplified text" and, as Mitchell B. Carroll stated, "the second (submitted by us)" ${ }^{\prime 314}$ reflects the influence of the United States of America, ${ }^{315}$ with the result that it was an MTC that aimed to be used for conventions between countries in which taxation by reference to domicile was a predominate feature. It provided for taxation at source for certain types of income, avoiding double taxation by allowing a credit for tax paid at source against the tax to be paid at the recipient's residence state. Passive investment

\footnotetext{
${ }^{311}$ Carrol, Mitchell B. Allocation of Business Income: The Draft Convention of the League of Nations. Columbia Law Review, Vol 34, 1934.

${ }^{312}$ League of Nations, Model Tax Convention, No. 1 A, 1928.

${ }^{313}$ Ibid, 313. Commentary on Article 3.

${ }^{314}$ Carrol, Mitchell B. Benefits for American Investors and Enterprises Abroad: Part 1. International Tax Law, Vol 2, 1968.

315 The United States of America joined the group in 1927.
} 
income, such as dividends, interest and royalties, were exempt from tax at source and were taxable only in the state in which the recipient had its fiscal domicile.

The third MTC, which aimed to be an MTC for conventions between countries with different fiscal systems in particular, ${ }^{316} 317$ also provided for taxation at source for certain types of income, similar to Model $1 \mathrm{~B}$ ). This was done by allowing taxation for the state of fiscal domicile of the recipient on dividends, interest and royalties, with the condition of avoiding double taxation by crediting any taxes withheld at source, i.e. allowing source taxation.

At least regarding the taxation of passive investment income, there were no great differences between MTC 1 B) and MTC 1 C). Even though MTC 1 A) - the basic Model - clearly recognized a recognition of the right of source countries to tax passive investment income, that power was limited in practice by the pattern of international flows of private capital in the era that preceded the Great Depression. ${ }^{318}$ The historical circumstances have easily distorted the real meaning of those concessions.

\subsection{2 - OECD MODEL TAX CONVENTION}

In 1956, the Organisation for European Economic Co-operation (OEEC) which subsequently became the Organisation for Economic Co-operation and Development (OECD), created its Fiscal Committee and entrusted it with the task of promulgating a draft model DTC “(...) which would effectively resolve the double taxation problems existing between OECD member countries and which would be acceptable to all member countries". ${ }^{319}$ From 1958 to 1961, the Fiscal Committee prepared four interim Reports before submitting its final Report in 1963 entitled "Draft Double Taxation Convention on Income and Capital”, ${ }^{320}$ with

\footnotetext{
${ }^{316}$ Maisto, Guglielmo. Residence of Individuals under Tax Treaties and EC Law, IBFD, 2010.

${ }^{317}$ League of Nations, Model Tax Convention, No. 1 A, 1 B and 1 C, 1928.

318 United Nations, Department of Economic and Social Affairs, Division for Public Administration and Development Management, Manual for the Negotiation of Bilateral Tax Treaties between Developed and Developing Countries, New York, 2003.

${ }^{319}$ OECD, Model Tax Convention on Income and Capital, 2017.

${ }^{320}$ Ibid, 320. Introduction - Historical background.
} 
recommendations to OECD member countries as to how to conform to this convention when signing or revising their bilateral conventions with other OECD countries.

The OECD MTC was developed in response to the needs of developed countries and it provided a firm and solid model to be followed in treaty negotiations. At the time of the publication of the 1963 OECD MTC, the following countries were OECD members: Austria, Belgium, Canada, Denmark, France, Federal Republic of Germany, Greece, Iceland, Ireland, Italy, Luxembourg, the Netherlands, Norway, Portugal, Spain, Sweden, Switzerland, Turkey, the United Kingdom and the United States. ${ }^{321}$ Thus, from the outset, the OECD MTC was created to be used by developed countries, which was historically justified by the "increasing economic interdependence and co-operation of the member countries of the OEEC in the post-war period showed increasingly clearly the importance of measures for preventing international double taxation". 322

The Fiscal Committee of the OEEC in its work between 1958 and 1961 left the discussion regarding the taxation of passive investment income until the end of the negotiations. The taxation of dividends, interest and royalties was finally included only in the fourth report that was submitted by the Fiscal Committee. The reason for this was put as follows in the introduction of the referred fourth report: “ (...) in its reports to the Council in July 1959 and July 1960, the Fiscal Committee submitted a number of Articles which, in addition to those it had already submitted in its first report, were intended to form the bases of the future Convention. But the most important and most difficult question, that of the taxation of dividends, interest and royalties, still remained to be settled. For, although agreement on the various questions covered by the first three reports had been reached with relative ease, it was found that the drafting of the Articles concerning dividends, interest and royalties, was a particularly long and arduous task". The Fiscal Committee realized that reaching an approach regarding the taxation of passive investment income was the most difficult part of

\footnotetext{
${ }^{321}$ Whittaker, Donald R. An examination of the O.E.C.D. and U.N. model tax treaties: history, provisions and application to U.S. foreign policy. North Carolina Journal of International Law and Commercial Regulation, Vol 8, 1982.

322 OECD, Model Tax Convention on Income and Capital, 2017.
} 
their work, ${ }^{323}$ and it categorized this problem as the chief obstacle that had to be overcome before a draft convention acceptable to all member countries of the OEEC could be established. $^{324}$

This fourth report was the basis for the 1963 OECD Draft MTC and therefore formed the basis of the approaches of the OECD and UN MTCs regarding the taxation and allocation of taxing rights regarding passive investment income. The promotion of a shared system of taxation - dividends and interest - between the source and the residence country by limiting source taxation to a certain threshold ${ }^{325}$ is, therefore, and for the purposes of this research, one of the key issues that must be explored in the history of the taxation of passive investment income.

The reasons used by the Fiscal Committee to justify the difficulty of this task demonstrated that the analysis of where the economic activity belongs that in turn gives rise to the income was only one of various elements involved in the analysis. ${ }^{326}$ The solution proposed by the Fiscal Committee was based more on practical than economic factors, and this approach was supported by the fact that OEEC countries, at that time, were on a level playing field in terms of development and were thus able to support the application of the reciprocity principle, ${ }^{327}$

${ }^{323}$ OEEC, Fourth Report by the Fiscal Committee, The Elimination of Double Taxation, Paris, June 19, 1961. Introduction: “(...) in the case of dividends, interest and royalties, the divergences between the economic interests of the States and also between their legislations are particularly marked and are the chief source of difficulty in the negotiation of bilateral Conventions on double taxation". Available at: http://www.taxtreatieshistory.org/

${ }^{324}$ OEEC, Fourth Report by the Fiscal Committee, The Elimination of Double Taxation, 1961.

${ }^{325}$ Only regarding interests and dividends.

${ }^{326}$ OEEC, Fourth Report by the Fiscal Committee, 1961. III Further results of the Committee's work. A) number 16: "As stated in the Introduction, the establishment of common rules for the avoidance of double taxation with respect to taxes on dividends, interest and royalties was a matter of major difficulty because of the divergences between the economic interests of Member countries, the very great dissimilarity in their tax laws and regulations, the differences in their theoretical concept of the question and also between the solutions adopted in practice in the bilateral Conventions on double taxation. These difficulties had already been brought out generally at the commencement of the League of a Nations' studies on double taxation after the first World War, particularly in the report prepared in 1923 by the group of four economists appointed by the Financial Committee of the League of Nations in 1921. These difficulties explain why rather different solutions were proposed for this problem in the various Model Conventions established by the League of Nations in 1928, 1943 and 1946. In fact, the clauses in regard to which the Mexico Model Convention of 1943 and the London Model Convention of 1946 differ most are those concerning the taxation of dividends, interest and royalties.". ${ }^{327}$ Ibid., 327. III Further results of the Committee's work. A) number 20: "These rules as to the right to tax are a balanced arrangement based on reciprocal concessions, which the Fiscal Committee regards as equitable. They have the advantage of being simple and easy to apply in practice. Their adoption by the Member countries in their bilateral Conventions would be a definite step forward since it would both afford a settlement of 
which did not require the economic allegiance of the taxpayer with the country through a neutral economic classification and assignment approach. The Fiscal Committee worked with the aim of reconciling the divergent interests of the member countries in a satisfactory manner with respect to the taxation of passive investment income. ${ }^{328}$ This fact is a crucial one, especially when assessing whether the UN MTC is able to achieve fairness regarding the taxation of passive income if the system is based on an MTC that aims to solve the problem of double taxation between countries with similar economic realities.

The approach proposed in the report regarding royalty income did not achieve consensus among the members. Spain, Greece, Luxembourg and Portugal - all capital importer countries in those years, informed the Fiscal Committee that they were not in a position to relinquish all tax at source, but suggested that they could restrict it to 5\% of the gross amount of the royalties. ${ }^{329}$ Due to the above, and which was surprisingly not the approach recommended by the OECD in treaties involving countries with different economic realities, the other countries ${ }^{330}$ declared that they were prepared, in bilateral conventions and subject to reciprocity, to concede to them the right to levy tax at source at $5 \%$ of the gross amount.

\subsubsection{1 - FISCAL COMMITTEE APPROACH - DIVIDENDS TAXATION}

The working party number 12 of the Fiscal Committee, formed by delegates of Germany, Italy and Switzerland, was in charge of studying the problems connected with the taxation of dividends and was to present a proposal with a view to framing a draft article to be inserted into an MTC.

The group based their work on the studies and proposals that were provided by the League of Nations and on the various solutions for dividend taxation that were contained in some

particularly difficult questions and make it possible to harmonies these Conventions on points where they show the greatest differences."

${ }^{328}$ Ibid, 327. III Further results of the Committee's work. A) number 22.

${ }^{329}$ Ibid, 327. III Further results of the Committee's work. A) number 20.

330 Austria, Belgium, Canada, Denmark, France, Federal Republic of Germany, Iceland, Ireland, Italy, the Netherlands, Norway, Sweden, Switzerland, Turkey, the United Kingdom, and the United States. 
earlier conventions. ${ }^{331}$ Thus, instead of looking to the nature of the income and then attributing the right to tax to the residence or the source country, the Fiscal Committee, through working party number 12, addressed the problem from the perspective of the different systems of dividend taxation in their member countries. ${ }^{332}$ The working party declared that in certain states, the principle of taxation at the place of residence was the rule and in other states the principle of taxation at the place where the income arises prevails ${ }^{333}$ and, therefore, in their first report on the taxation of dividends they prepared two draft articles. Draft A was based on the principle of taxing dividends in the state of residency but granting limited rights to the source state to tax and Draft B allowed each state the right to tax dividends in accordance with their own laws but limited any tax charged at source to $15 \%$ and to $5 \%$ in the case of dividends paid to controlling companies. The above was justified in order to use Draft A in DTCs between states that were prepared to follow the principle of taxation in the state of which the shareholder was a resident and to reduce the rate of tax at source considerably, and Draft B was to be used in DTCs where one of the contracting states wished to have a more extensive right to tax dividends paid by a resident company. ${ }^{334}$

The working party justified the application of the residence country approach instead of a source country approach with the following arguments:

(1) It would be difficult to apply the principle of territoriality to dividends; the source state is not necessarily the state in which the capital has been invested;

(2) Taxing dividends in the residence state of the shareholder also makes it possible to observe the dominant principle of taxing according to taxable capacity; and,

(3) The principle of taxation in the residence state of the recipient is contained in several conventions for the avoidance of double taxation that have been concluded between the member countries of the OEEC.

${ }^{331}$ OECD. Working Party No. 12 of the Fiscal Committee (Germany - Italy - Switzerland). Report on the taxation of Dividends, 1958. Available at: http://www.taxtreatieshistory.org/

${ }_{332}$ Ibid, 332.

${ }_{333}^{33} \mathrm{Ibid}, 332$.

${ }^{334}$ Ibid, 332. 
This demonstrated the lack of economic analysis that was present in the adoption of the allocation of taxing rights approach, the prevalence of practical reasons, and the fact that the work done was never intended to be used in DTCs between countries with important developmental differences.

On 19 January 1959, the Italian delegation sent a confidential note to the Fiscal Committee regarding the taxation of dividends. At that time, Italy was a capital importer country and its taxation system was predominantly based on the principle of taxation at the place where the income was produced. This being so, even a partial renunciation by Italy of taxation at the place of source represented a real sacrifice without any real compensation. ${ }^{335}$ At that time, Italy more or less faced the same problems that developing countries face today regarding the allocation of taxing rights in relation to passive investment income in DTCs signed with developed countries under the UN MTC. The sacrifice without compensation for Italy stemmed from the design of their taxation system - territorial taxation - which is comparable with the situation of developing countries regarding the lack of reciprocal investments.

Italy argued that a reduction in the rate of tax on dividends at source might be justified if the recipient resident abroad confines itself to owning shares in Italian companies. But, when in addition to drawing dividends, the recipient directly carries on an industrial or commercial business in Italy through a permanent establishment, i.e. taking an active and direct part in the country's economic life, then there would be nothing to justify preferential treatment. Italy basically claimed that dividends were part of a more active than passive activity due to the fact that the recipients participate in an active and direct way in the country's economic life. For the author, there is no doubt that the Italian approach was correct. They were analysing dividends on a case-by-case basis and then properly allocating taxing rights. The Italian argument was not a purely practical approach influenced by their tax system, because Italy agreed to a reduction of source taxation when the recipients were not contributing, in an active way, to the country's economic life - passive income - and granted full taxing rights to the source state when the recipients were clearly contributing, in an active way, to

${ }^{335}$ Ibid, 332. See note by the Italian delegation. 
the country's economic life. The Italian approach is what is now argued by countries that have implemented a participation exemption, i.e. to consider exempt from tax dividends that derive from foreign direct investments / active participation, as giving preference to tax to source countries.

As was stated earlier, the approach proposed by the Fiscal Committee was the basis of the 1963 OECD Draft MTCs and therefore it also became the basis for the OECD and UN MTCs. The committee recognized that, after combining the work done by the LN and by some DTCs concluded until then, they would have to choose a text that would be acceptable to the majority of OEEC members. The final draft article states that dividends shall be taxable in the state where the shareholder has its residence, conferring a limited concurrent right to tax on the source state. The rates fixed by the draft article for the tax in the source state were the maximum rates. 336

\subsubsection{2 - FISCAL COMMITTEE APPROACH - INTEREST TAXATION}

The working party number 11 of the Fiscal Committee, which was formed by delegates of France and Belgium, was tasked with studying the problems connected with the taxation of interest and presented a proposal with a view to framing a draft article that could be inserted into an MTC.

The working party decided not to re-open the doctrinal discussions on the merits of taxing interest income in the state of source or in the state of residency of the recipient according to whether the tax was personal or impersonal. Nor to consider whether the theoretically ideal taxation of income from movable property should be a privilege of the state of the creditor's residency by virtue of the principle that movable property income is intimately associated or related to the person of its owner and, therefore, tax on that income should be incurred by the owner. Thus, the working party did not consider the work of the LN and started its work on the basis of the following observations and considerations:

\footnotetext{
${ }^{336}$ OECD, Working Party No. 12 of the Fiscal Committee (Germany - Italy - Switzerland). Second Report on the taxation of Dividends, 1960. Available at http://www.taxtreatieshistory.org/
} 
(1) The methods that had thus far been advocated for taxing interest were not uniform. Furthermore, they were not, generally speaking, followed by the member countries of the OEEC, which had adopted various methods that provided a whole range of solutions, most of them differing more or less widely from the recommendations given by the LN; ${ }^{337}$

(2) The countries that export capital and the countries investing it have different positions regarding the taxation of interest. The former are naturally inclined to tax that income in the state of the recipient's residence and the latter wish to tax that income in the state where the income has arisen; ${ }^{338}$

(3) By raising the question: can it be said that the countries where the capital is invested are making an unreasonable claim when they will benefit not only from the development of their economies and the increase in wealth which will not only result from the investment but also by a taxable substance which will bring them new taxation revenue? ${ }^{339}$

(4) To answer that question the working group took into consideration the fact that capital import countries were not in a good enough financial position to achieve development on their own. The working party even referred to the recommendation made by the United Nations Organization, which invited capital export countries, as far as possible, to leave the benefit of taxation of the revenue from such investment to the country in which the capital has been invested, but they considered this to be a recommendation which could not be applied since the discussion was premised on the member countries of the OEEC. ${ }^{340}$

Notwithstanding this last observation, the report stated that there were other considerations which justify taxation in the state of source of the income, even when movements of capital take place between states with similar levels of development. The working party concluded

\footnotetext{
337 OECD, Working Party No. 11 of the Fiscal Committee (France and Belgium). Report on the taxation of Interest, 1959. Available at: http://www.taxtreatieshistory.org/

${ }_{338}^{33} \mathrm{Ibid}, 338$.

${ }^{339} \mathrm{Ibid}, 338$.

${ }^{340} \mathrm{Ibid}, 338$.
} 
that the avoidance of double taxation requires some sacrifices which must be equal if the measures were to be acceptable to both sides. ${ }^{341}$

Thus, it seems that both solutions, that which gives an exclusive right to tax to the country of source of the interest and that which reserves it to the country of the creditor's residence, were too rigid. Therefore, this made it necessary to find a compromise whereby uniformity might be achieved in the OEEC countries' methods of taxing interest and whereby the differing points of view can be reconciled. The report recognized that the proposed approach was more pragmatic than theoretical. ${ }^{342}$

As in the work done regarding dividend taxation, the working party, instead of looking to the nature of the income and then attributing the right to tax to the residence or to the source country, simply focused on the different systems of interest taxation of their member countries and at the DTCs that had been concluded by those countries until then. Ultimately, and as the approach which formed the basis of the 1963 OECD Draft Model and consequently the basis for the OECD and UN MTCs, the committee followed the recommendation given by the working party which was extracted from the approach that was followed in Article 6 A of the treaty that was signed on 22 June 1956 between the United States and France.

The working party briefly considered the nature of the income and took as a starting point the principle that it is logical to give a priority right to the source state with respect to income from immovable property and income from different kinds of business activity. However, in the case of investment income, it would be more reasonable for the priority right to be reserved to the state of residence. Moreover, they also considered, as working party 12 did regarding the study of dividend taxation, the fact that interest attributable to a permanent establishment belonging to the recipient resident in the other state - if the interest arises from debt-claims forming part of the permanent establishment's assets or if it pertains to transactions made by the permanent establishment or arises from loans which have a clear

\footnotetext{
${ }^{341}$ Ibid, 338.

${ }^{342}$ Ibid, 338.
} 
economic connection with the permanent establishment - should be taxed by the source state. $^{343}$

On 17 March 1959, the Italian delegation once again sent a confidential note to the Fiscal Committee regarding the taxation of interest. As was stated regarding dividend taxation, at that time Italy was a capital importer country and its taxation was predominantly based on the principle of taxation at the place where the income is produced. Due to the above, the principle followed by Italy - based on economic and practical reasons - was at risk of being completely circumvented by an approach like the one proposed by working party 11 . In the note, it was stated that if Italy were to relinquish the right to levy tax on interest flowing from Italy to other countries, the result would be an unrequited loss which the Italian economy could not afford to sustain. Moreover, as was also stated regarding dividend taxation and the Italian reality, at that time Italy more or less was facing the same issues that developing countries face today in DTCs that are signed with developed countries under the UN MTC.

In the second, third and fourth reports that were issued by working party number 11, it was even more explicit that the main purpose of the working party was to present an approach that was amenable to all delegations of the member countries, instead of an approach that was based on the nature of the income and the correspondingly fair allocation of taxing rights. Ultimately, the committee chose a text that was acceptable to the vast majority of OEEC members. The final draft article states that interest shall be taxable in the state of the recipient residence, conferring a limited concurrent right to tax on the source state of up to $10 \%$, i.e. the maximum rate.

\subsubsection{3 - FISCAL COMMITTEE APPROACH - ROYALTIES TAXATION}

Working party number 8 of the Fiscal Committee, which was formed of delegates from Germany and Luxembourg, was in charge of studying the problems connected with the

\footnotetext{
${ }^{343}$ Ibid, 338.
} 
taxation of patent royalties and similar payments, and it was charged with presenting a proposal with the view to framing a draft article to be inserted into an MTC.

Working party number 8 based its work on the studies and proposals provided by the LN and on the various solutions for royalty taxation that were contained in some earlier conventions. $^{344}$

Regarding dividend and interest taxation, the work done by the Fiscal Committee through working party number 8 did not address the problem from an economic point of view. In other words, they did not add any value to the work that had already been carried out by the LN - particularly the London Model - and by the OEEC countries in treaties that were signed by some OEEC members.

As is known, the $1928 \mathrm{LN}$ Models did not contain specific rules regarding royalties and the taxation of similar payments. Thus, this income was only taxed by the country where the grantor resided, unless the income was derived through a permanent establishment of the grantor in the other state. ${ }^{345}$ The Mexico Model made a distinction between (1) patents, secret processes or formulas, a trademark or other analogous rights and (2) musical, artistic, literary, scientific or other cultural work. It granted exclusive rights to tax to the source state regarding the income derived from the sources listed in (1) and exclusive rights to tax to the grantor residence country regarding the income derived from the sources listed in (2). The London Model did not make such a distinction, as it granted exclusive taxation rights to the grantor residence country regarding both sets of incomes.

In relation to treaties signed between OEEC countries, working party number 8 used the treaties between Norway and United Kingdom, ${ }^{346}$ Austria and Switzerland, ${ }^{347}$ France and

${ }^{344}$ OECD, Working Party No. 8 of the Fiscal Committee (Germany and Luxemburg). Report on the direct taxation of Patent Royalties and similar payments, 1958. Available at: http://www.taxtreatieshistory.org/

${ }^{345} \mathrm{Ibid}, 342$.

3462 May 1951.

${ }^{347} 12$ November 1952. 
Switzerland, ${ }^{348}$ Denmark and Sweden ${ }^{349}$ and Austria and the Federal Republic of Germany ${ }^{350}$ for the purposes of its analysis. All of these treaties adopted the principles that were set forth in the London Model, which consequently eradicated any chance of discussion, at least in those years, of the active or passive elements of the income and, thus, the corresponding fair allocation of taxing rights between the source and the residence country. Ultimately, working party number 8 simply focused on preparing a draft article which would conform to the conventions that had been previously concluded by the OEEC members. ${ }^{351}$

The best way to provide an example of the above is to reproduce the argument that was given by working party number 8 in its second report. ${ }^{352}$ This was a response to the recommendations given by the Austrian, United Kingdom and Italian delegations on their proposals regarding source countries' rights to tax. The Austrian delegation proposed granting rights to tax to the source state in respect of industrial and commercial royalties that were paid by subsidiaries to their parent companies; the United Kingdom delegation raised the question of whether a right to tax should be given to the source state in cases where the state of residence does not tax and the Italian delegation proposal related to the source state's right to tax when the recipient of the royalties had a permanent establishment or a fixed base in the state of the payer. Working party number 8 , instead of analysing the arguments of those proposals, answered all of the proposals by stating that the adoption of one of those approaches would constitute a derogation from most DTCs in force between OEEC members, and they did so by confirming that the aim of their work was not to analyse the nature of the income in order to fairly allocate taxing rights.

Consistent with the above, the supplementary memorandum that was issued by working party number 8 , on 10 November 1958, only addressed the issue of source state taxation of royalty income from a practical perspective. In that memorandum, working party number 8 agreed

\footnotetext{
34831 December 1952.

34927 October 1953.

3504 October 1954.

351 OECD, Working Party No. 8 of the Fiscal Committee (Germany and Luxemburg). Report on the direct taxation of Patent Royalties and similar payments, 1958. Available at: http://www.taxtreatieshistory.org/ ${ }^{352}$ Ibid, 352.
} 
with the fact that, when double taxation is prevented by bilateral conventions, ${ }^{353}$ the source country can have limited rights to tax when special conditions arise. That scenario was the result of the understanding that in light of the economic relations between the two contracting states, it would not be correct to deprive the source state of all rights to tax royalties. ${ }^{354}$ Moreover, the working party agreed that a 5\% withholding tax on the gross amount was the maximum that it would recommended to be agreed in a DTC, since another rate would result in a major derogation from the principle that the state of residence should have the exclusive right to tax. This was reflected in the London Model and in the majority of the treaties that had been concluded by OEEC members until then.

Only one delegation analysed the problem of the allocation of taxing rights regarding royalty income from a more substantial perspective. On 2 December 1958, the secretariat of the Fiscal Committee circulated amongst its members the Belgian note regarding the principles of tax allocations on royalty income. The Belgian delegation considered that there was no justification for giving the exclusive right to tax royalties to the country of residence of the recipient - the grantor. They supported the view that it seemed to be correct to allow the country in which the right is used to levy a reasonable tax on the net income obtained by the foreign grantor by virtue of such use. ${ }^{355}$

One of the justifications that was put forth by the Belgian delegation for their proposal was the possibility of finding compensation on other points - when bilateral conventions are being negotiated between Member countries of the OEEC (some of which had very similar industrial structures) - for the sacrifice accepted by a country which would have an excessive outflow of royalties. The justification addressed the problem of non-reciprocity of royalty flows, an issue of immense relevance in treaties between developing and developed countries and which form the core of this research. The Belgian delegation proposed an approach of

\footnotetext{
${ }^{353}$ The working party was of the opinion that in a multilateral convention the right to tax royalties should be conferred exclusively on the state of which the recipient is a resident.

354 OECD, Working Party No. 8 of the Fiscal Committee (Germany and Luxemburg). Supplementary Memorandum to the Second Report on the direct taxation of Patent Royalties and similar payments, 1958. Available at: http://www.taxtreatieshistory.org/

${ }^{355}$ OECD, Direct taxation of Patent Royalties and similar payments (Note by the Secretariat), 1958. Available at: http://www.taxtreatieshistory.org/
} 
limited taxing rights to the source state and unlimited taxing rights to the residence state with the obligation to avoid double taxation through the enactment of a credit method. The Belgian delegation recognized the difficulties in agreeing a uniform formula for limiting taxation in the state of source, regardless of whether the limit is applied to the tax base or to the rate of $\operatorname{tax}^{356}$

With regard to royalty taxation, it was even more explicitly stated in the third ${ }^{357}$ and in the fourth $^{358}$ reports issued by working party number 8 that the main purpose of the working party was to present an approach which could be approved by all the delegations of the member countries, instead of an approach based on the nature of the income and correspondingly the fair allocation of taxing rights. Ultimately, the committee chose a text which was acceptable to the great majority of OEEC members. The final draft article states that royalties shall be taxable in the state of residence of the recipient, conferring rights to tax on the source country only when the recipient has a permanent establishment to which the right giving rise to the royalties actually pertains. The third and fourth reports simply deleted any possibility of source taxation on both a gross or net basis.

\subsubsection{4 - OECD MODELS FROM 1963 to 2015.}

The result of seven years of work of the Fiscal Committee ${ }^{359}$ was the "Draft Double Taxation Convention on Income and Capital" that was presented and adopted on 30 July 1963, with recommendations to OECD member countries to conform to this draft convention when signing or revising their bilateral DTCs.

The establishment of common rules for the OECD regarding Articles 10, 11 and 12 dividends, interest and royalties respectively - was the major difficulty of the Fiscal

\footnotetext{
356 Ibid, 356.

${ }^{357}$ OECD, Working Party No. 8 of the Fiscal Committee (Germany and Luxemburg). Revised Third Report on the taxation of Royalties, 1961. Available at: http://www.taxtreatieshistory.org/

${ }^{358}$ OECD, Working Party No. 8 of the Fiscal Committee (Germany and Luxemburg). Revised Fourth Report on the taxation of Royalties, 1961. Available at: http://www.taxtreatieshistory.org/

${ }^{359}$ In total were 37 sessions each covering a period of three days. 26 of these sessions were held between May 1956 and September 1961 in the OEEC, and 11 from November 1961 to June 1963 in the OECD.
} 
Committee as a result of the divergences between the economic interests of the member countries, the great dissimilarity in their laws, and the differences in their theoretical concept of the question and also between the solutions that were adopted in practice in bilateral DTCs. ${ }^{360}$ Ultimately, the rules of attribution that are contained in the 1963 Draft MTC represent a balance of reciprocal concessions between the member countries which favuor taxation by the state of residence and those which favour taxation by the source state. This solution - concessions - was possible, and has worked until now, due to the similarity of investment flows between OECD members.

The compromise consisted of granting exclusive rights to tax royalties ${ }^{361}$ to the state in which the recipient was resident and on the share of the right to tax dividends ${ }^{362}$ and interest ${ }^{363}$ between the state in which the recipient was resident and the state in which the income was sourced. In practice, the right to tax of the source state was restricted to levying a tax up to a certain rate, a tax that the residence state was forced to take into account in computing its own tax so as to avoid juridical double taxation.

Besides the fact that Article 12 stated that royalties were only taxable by the residence country, the other articles governing passive investment income were similar and had almost identical wording. Each article sets forth the rule of attribution for the right to tax, defines the income - the taxation of which it regulates - and then provides an exception to the above rules in cases where that income is more actively connected to the source country. Thus, when the recipient has a permanent establishment in the other contracting state with which the equity on which the dividends were paid, the indebtedness on which the interest was paid, or the property or right in respect of which the royalties were paid, were effectively connected, then the source state regains its taxing rights.

\footnotetext{
${ }^{360}$ OECD, Council, Report of the Fiscal Committee on the Draft Convention for the Avoidance of Double Taxation with respect to taxes on Income and Capital among the Member Countries of the O.E.C.D, 1963. Available at: http://www.taxtreatieshistory.org/

${ }^{361}$ OECD, Model Tax Convention on Income and Capital, 1963, Article 12.

${ }^{362}$ Ibid, 362. Article 10.

${ }^{363}$ Ibid, 362. Article 11.
} 
The 1963 OECD Draft MTC mostly followed the approach of the 1946 LN London MTC and it was definitively influenced by the various solutions contained in some pre-existent conventions between OECD countries. This has influenced the tax treatment of passive investment in DTCs since then.

The solution embodied by this Draft MTC became the basis not only for the models which were intended to be followed by treaties between developed countries but also for the UN MTC, which, by its very definition, was supposedly created to be followed in treaties between developing and developed countries.

The result of the revision to the 1963 Draft MTC by the Fiscal Committee of the OECD from 1967 onwards was the 1977 MTC on Income and Capital. The most important change of the latter MTC regarding passive investment income, was the inclusion of the term "beneficial owner". 364365366 This addition, which indirectly affects the approach to the allocation of taxing rights in relation to passive investment income, ${ }^{367}$ was inserted with the purpose of denying the treaty benefits when an intermediary, such as an agent or nominee, was interposed between the beneficiary and the payer. ${ }^{368}$ Thus, if there was an intermediary, such as an agent or nominee, in between the beneficiary and the payer, unless the beneficial owner was a resident of the other contracting state, the limitation to tax for the source state was no longer enforceable.

\footnotetext{
${ }^{364}$ OECD, Model Tax Convention on Income and Capital, 1977, Article 10 paragraph 2.

${ }^{365} \mathrm{Ibid}, 365$. Article 11 paragraph 2.

${ }^{366} \mathrm{Ibid}, 365$. Article 12 paragraph 2.

${ }^{367}$ Because the limitation to tax in the state of source was no longer granted.

368 OECD, Model Tax Convention on Income and Capital, 1977, commentary on Article 10 paragraph 2., commentary on Article 10 paragraph 2.
} 
In addition to the above, in the three articles the MTC extended the application of extra rules in order to protect source countries' rights not only in the case of permanent establishments according to Article 7, but also in the case of a fixed base according to Article 14. 369370371

The revision of the 1977 MTC resulted in the 1992 MTC. This new consolidated version of the MTC took into account the experience gained by the member countries in the negotiation and practical application of bilateral conventions that has taken place since $1977 .{ }^{372}$ The globalization and liberalization of the OECD economies accelerated rapidly in the 1980s. Consequently, after 1977 the Committee on Fiscal Affairs continued to examine various issues that were directly or indirectly related to the 1977 MTC. This work resulted in a number of reports, some of which recommended amendments to the MTC. ${ }^{373}$

Unlike the 1963 Draft MTC and the 1977 MTC, the revised 1992 MTC did not represent a comprehensive revision. The OECD approach was to view this MTC as the first step in an ongoing revision process that was intended to produce periodic updates, thereby ensuring that the MTC continues to accurately reflect the views of member countries at any point in time and to respond to the needs of taxpayers. ${ }^{374}$

\footnotetext{
${ }^{369} \mathrm{Ibid}, 369$. Article 10 paragraph 4: "The provisions of paragraphs 1 and 2 shall not apply if the beneficial owner of the dividends, being a resident of a Contracting State, carries on business in the other Contracting State of which the company paying the dividends is a resident, through a permanent establishment situated therein, or performs in that other State independent personal services from a fixed base situated therein, and the holding in respect of which the dividends are paid is effectively connected with such permanent establishment or fixed base. In such case the provisions of Article 7 or Article 14, as the case may be, shall apply."

${ }^{370} \mathrm{Ibid}, 369$. Article 11 paragraph 4: "The provisions of paragraphs 1 and 2 shall not apply if the beneficial owner of the interest, being a resident of a Contracting State, carries on business in the other Contracting State in which the interest arises, through a permanent establishment situated therein, or performs in that other State independent personal services from a fixed base situated therein, and the debt-claim in respect of which the interest is paid is effectively connected with such permanent establishment or fixed base. In such case the provisions of Article 7 or Article 14, as the case may be, shall apply."

${ }^{371}$ Ibid., 369 Article 12 paragraph 3: "The provisions of paragraph 1 shall not apply if the beneficial owner of the royalties, being a resident of a Contracting State, carries on business in the other Contracting State in which the royalties arise, through a permanent establishment situated therein, or performs in that other State independent personal services from a fixed base situated therein, and the right or property in respect of which the royalties are paid is effectively connected with such permanent establishment or fixed base. In such case the provisions of Article 7 or Article 14, as the case may be, shall apply."

${ }^{372}$ OECD, Model Tax Convention on Income and Capital, 1992.

${ }^{373}$ Ibid, 373.

${ }^{374}$ OECD, Model Tax Convention on Income and Capital, 2017. Introduction.
} 
The phrase "or for the use of, or the right to use, industrial, commercial or scientific equipment" was deleted from Article 12 (2) of the OECD Model following a recommendation in paragraph 23 of the OECD Leasing Report. The removal of these payments from the definition means that they now fall within the terms of the business profits article and, thus, from an allocation of taxing rights perspective, the removal of that phrase from the OECD MTC has resulted in an increase of the source country's rights to tax in DTCs between developed countries. ${ }^{375}$ The above effect will not be achieved if the same change is made in the UN MTC, since in the UN MTC source countries have rights to tax royalty payments as a percentage of gross revenues with a limited withholding tax. The OECD legal analysis arrives at the correct conclusion that income from copyrights, patents, knowhow, etc., constitute real royalty income, as opposed to income from leasing, which should not be regarded as real or proper royalty income, but should rather be categorized as rent from letting.

The Model was updated in the 1994, 1995, 1997, 2000, 2003, 2005, 2008, 2010, 2015 and 2017. It was only in the 2000 update that a common modification of the articles dealing with the taxation of passive investment income was undertaken.

The exclusion of Article 14 from the OECD MTC, due to the unjustified separate treatment of independent personal services from business profits according to the OECD, makes the term "fixed base", that is included in the 1977 Model in Articles 10, 11 and 12 thereof, somewhat redundant. ${ }^{376}$ From then on, only the term "permanent establishment" applies to protect source countries' rights to tax dividends, interest and royalties which are effectively connected to business activities or to personal independent services activities.

\footnotetext{
375 This amendment was deemed necessary because member states of the OECD did not strictly adhere to the idea of tax royalties only in the state of residence. See du Toit, C.P. Beneficial Ownership of Royalties in Bilateral Tax Treaties. Faculty of Law University of Amsterdam, 1999. Available at: http://dare.uva.nl/document/470938

${ }^{376}$ OECD, Model Tax Convention on Income and Capital, 1977. Article 10 paragraph 4; Article 11 paragraph 4; and Article 12 paragraph 3.
} 


\subsection{CURRENT UN AND OECD MTCS RULES REGARDING PASSIVE INVESTMENT INCOME TAXATION}

The latest version of the UN MTC from 2017 and the latest version of the OECD MTC, also from 2017, do not deviate, at least substantially, in relation to passive investment income from that which was already in force in the 1980s. However, due to the undoubted influence of the OECD MTC on the UN MTC, it is necessary to examine the differences between both approaches in detail.

As explained before, the approach used by the UN MTC (dividends, interest and royalties), which was influenced by the OECD MTC (dividends and interest), is a mechanism by which the source country levies a withholding tax on gross income and the resident country avoids juridical double taxation by granting an ordinary credit to the recipient - up to the withholding tax paid in the source country - thereby retaining the right to tax that income at the recipient level without any limitations. The OECD MTC grants exclusive taxing rights to the residence country regarding the taxation of royalty income.

The residence country taxation approach that is followed by both models regarding the three types of income is limited when the beneficial owner of the investment income, being a resident of a contracting state, carries on business in the other contracting state through a permanent establishment or, in the case of the UN MTC, performs independent personal services in that other state from a fixed base that is situated therein and the investment income is effectively connected to that permanent establishment - UN MTC and OECD MTC - or fixed base - UN MTC. At that point, such income is considered to be business profits and is taxed accordingly.

In both models, the country where the recipient of the income - the individual or entity - is resident will be responsible for eliminating the juridical double taxation, thereby assuming the burden of that responsibility by granting a foreign tax credit. ${ }^{377}$ One of the principal

\footnotetext{
${ }^{377}$ Whittaker, Donald R. An examination of the O.E.C.D. and U.N. model tax treaties: history, provisions and application to U.S. foreign policy. North Carolina Journal of International Law and Commercial Regulation, Vol 8, 1982.
} 
defects of the foreign tax credit method in the eyes of developing countries is that the benefit of low taxes in developing countries or of special tax concessions granted by them may, for the large part, favour the treasury of the capital exporting country - developed country rather than the foreign investor for whom the benefits were designed. Thus, and as a direct effect, the application of that method in a scenario in which the domestic law of the developing country intends to stimulate foreign investment through lower tax rates results in the shift of tax revenue from the developing country to the capital-exporting country. ${ }^{378}$

The shared system of taxation approach adopted by the UN MTC regarding the taxation of dividends, interest and royalties directly limits the extent of the source country's jurisdiction to tax this income. The limitation - the rate of the tax - is left open by the UN MTC to be agreed upon in the negotiations by treaty partners with the aim of differentiating this approach from that which was adopted by the OECD MTC regarding dividends and interest. As was verified when the history of the tax treatment of investment passive incomes was reviewed, such approach, right from the beginning, was not accepted by developed countries as the approach to be used in treaties among themselves. Therefore, in most instances, no thought was given to the problems that were faced by capital-importing countries developing countries. ${ }^{379}$ An approach that does not consider effective incentives for the foreign investor to invest in the source country - developing country - conflicts with developing countries' aims when they are concluding a DTC with a developed country.

In practice both approaches are mainly designed with the same logic regarding the taxation of passive investment income. A general overview of the treatment of traditionally known passive income under both models through a comparative analysis is required in order to set ground rules for proposals.

\footnotetext{
${ }^{378}$ United Nations, Department of Economic and Social Affairs, Model Double Taxation Convention between Developed and Developing Countries, 2017. Commentary on Article 23, General Considerations.

${ }^{379}$ Whittaker, Donald R. An examination of the O.E.C.D. and U.N. model tax treaties: history, provisions and application to U.S. foreign policy. North Carolina Journal of International Law and Commercial Regulation, Vol 8, 1982.
} 


\subsection{1 - TAXATION OF DIVIDENDS}

UN MODEL-2017
1. Dividends paid by a company which is a resident of
a Contracting State to a resident of the other
Contracting State may be taxed in that other State.
2. However, such dividends may also be taxed in the
Contracting State of which the company paying the
dividends is a resident and according to the laws of
that State, but if the beneficial owner of the dividends
is a resident of the other Contracting State, the tax so
charged shall not exceed:

(a) _ per cent (the percentage is to be established through bilateral negotiations) of the gross amount of the dividends if the beneficial owner is a company (other than a partnership) which holds directly at least 25 per cent of the capital of the company paying the dividends throughout a 365 day period that includes the day of the payment of the dividend (for the purpose of computing that period, no account shall be taken of changes of ownership that would directly result from a corporate reorganization, such a as a merger or divisive reorganization, of the company that holds the shares or that pays the dividends);

(b) _ per cent (the percentage is to be established through bilateral negotiations) of the gross amount of the dividends in all other cases.

The competent authorities of the Contracting States shall by mutual agreement settle the mode of application of these limitations.

This paragraph shall not affect the taxation of the company in respect of the profits out of which the dividends are paid.

3. The term "dividends" as used in this Article means income from shares, "jouissance" shares or "jouissance” rights, mining shares, founders' shares or other rights, not being debt claims, participating in profits, as well as income from other corporate rights which is subjected to the same taxation treatment as income from shares by the laws of the State of which the company making the distribution is a resident.

4. The provisions of paragraphs 1 and 2 shall not apply if the beneficial owner of the dividends, being a resident of a Contracting State, carries on business in the other Contracting State of which the company paying the dividends is a resident, through a permanent establishment situated therein, or performs in that other State independent personal services from a fixed base situated therein, and the holding in respect of which the dividends are paid is effectively connected with such permanent establishment or fixed base. In such case the provisions of Article 7 or Article 14, as the case may be, shall apply.

5. Where a company which is a resident of a Contracting State derives profits or income from the other Contracting State, that other State may not impose any tax on the dividends paid by the company, except in so far as such dividends are paid to a resident of that other State or in so far as the holding
OECD MODEL - 2017

1. Dividends paid by a company which is a resident of a Contracting State to a resident of the other Contracting State may be taxed in that other State.

2. However, dividends paid by a company which is a resident of a Contracting state may also be taxed according to the laws of that State, but if the beneficial owner of the dividends is a resident of the other Contracting State, the tax so charged shall not exceed:

a) 5 per cent of the gross amount of the dividends if the beneficial owner is a company which holds directly at least 25 per cent of the capital of the company paying the dividends throughout a 365 day period that includes the day of the payment of the dividend (for the purpose of computing that period, no account shall be taken of changes of ownership that would directly result from a corporate reorganization, such as a merger or a divisive reorganization, of the company that holds the shares or that pays the dividend);

b) 15 per cent of the gross amount of the dividends in all other cases.

The competent authorities of the Contracting States shall by mutual agreement settle the mode of application of these limitations. This paragraph shall not affect the taxation of the company in respect of the profits out of which the dividends are paid.

3. The term "dividends" as used in this Article means income from shares, "jouissance" shares or "jouissance" rights, mining shares, founders' shares or other rights, not being debt-claims, participating in profits, as well as income from other corporate rights which is subjected to the same taxation treatment as income from shares by the laws of the State of which the company making the distribution is a resident.

4. The provisions of paragraphs 1 and 2 shall not apply if the beneficial owner of the dividends, being a resident of a Contracting State, carries on business in the other Contracting State of which the company paying the dividends is a resident through a permanent establishment situated therein and the holding in respect of which the dividends are paid is effectively connected with such permanent establishment. In such case the provisions of Article 7 shall apply.

5. Where a company which is a resident of a Contracting State derives profits or income from the other Contracting State, that other State may not impose any tax on the dividends paid by the company, except insofar as such dividends are paid to a resident of that other State or insofar as the holding in respect of which the dividends are paid is effectively connected with a 
in respect of which the dividends are paid is effectively connected with a permanent establishment or a fixed base situated in that other State, nor subject the company's undistributed profits to a tax on the company's undistributed profits, even if the dividends paid or the undistributed profits consist wholly or partly of profits or income arising in such other State. permanent establishment situated in that other State, nor subject the company's undistributed profits to a tax on the company's undistributed profits, even if the dividends paid or the undistributed profits consist wholly or partly of profits or income arising in such other State.

In both the UN MTC and the OECD MTC, Article 10 states that dividends derived from investments in the source country may be taxed by the residence country and also, but with some limitations, by the source country. This approach, which we can refer to as a shared system of taxation with a restriction at source, was criticized when the UN MTC was first considered. Members of the group of experts that represented developing countries felt that, as a matter of principle, dividends should only be taxed by the source state or at least taxed strongly in the source country. ${ }^{380}$

The UN MTC does not specify the maximum dividend withholding tax rate that is allowed to the source country. It left the threshold subject to the negotiations between prospective treaty partners. ${ }^{381}$ On the other hand, the OECD MTC sets a maximum withholding tax rate of 5\% for the source country regarding foreign direct investment dividends and a 15\% maximum for portfolio investments.

Regarding the threshold to determine if a dividend is a foreign direct investment or a portfolio investment, the 2017 UN MTC chooses to equate the $25 \%$ threshold imposed by the OECD MTC. In applying such limitations on taxing dividends, both Models require that the beneficial owner of the dividend be resident in the other contracting state.

\footnotetext{
${ }^{380}$ United Nations, Department of Economic and Social Affairs, Model Double Taxation Convention between Developed and Developing Countries, 2017. Commentary on Article 10 paragraph 1.

${ }^{381}$ Lennard, Michael. The UN Model Tax Convention as compared with the OECD Model Tax ConventionCurrent points of difference and recent developments. IBFD, Asia-Pacific Tax Bulletin, Vol 49, 2009.
} 
The logic behind this somewhat surprising approach demonstrates that the design of the article was no more than the result of non-economic negotiations. On the one hand, developing countries - source countries - feel that they benefit from leaving the rates of withholding taxes open and that this benefit is fully compensated for developed countries residence countries - by lowering the rate of participation necessary to determine when dividends correspond to foreign direct investments instead of portfolio investments.

As is stated in the UN MTC commentaries to this article, the UN MTC reproduces Article 10 of the OECD MTC, with the exception of paragraph two which contains substantive differences and paragraphs four and five which refer to independent personal services.

Regarding Article 10, paragraph two, the difference is that the UN MTC left the threshold of withholding tax to be charged at source subject to negotiations between the prospective treaty partners, while the OECD MTC states a fixed and maximum rate of 5\% for foreign direct investment dividends and a $15 \%$ maximum for portfolio investment dividends.

In paragraph four, the UN MTC adds to the OECD approach regarding permanent establishment restrictions on applying paragraphs one and two and consequently the application of Article 7, by stating that if the beneficial owner, by being resident of a contracting state, performs independent personal services in the state where the company paying the dividends is resident from a fixed base situated therein, and the holding in respect of which the dividends are paid is effectively connected with such a fixed base, then Article 14 will apply.

Lastly, regarding paragraph five, the only difference between the UN MTC and the OECD MTC is that in paragraph five there is a reference to the "fixed base" concept as an addition to the "permanent establishment" concept. This is related to the prohibition that a contracting state has on taxing dividends paid by a company resident in the other state, solely because the company derives income or profits from the taxing state. 


\subsection{2 - TAXATION OF INTEREST}

UN MODEL - 2017
1. Interest arising in a Contracting State and paid to
a resident of the other Contracting State may be taxed
in that other State.
2. However, such interest may also be taxed in the
Contracting State in which it arises and according to
the laws of that State, but if the beneficial owner of the
interest is a resident of the other Contracting State,
the tax so charged shall not exceed per cent (the
percentage is to be established through bilateral
negotiations) of the gross amount of the interest.

The competent authorities of the Contracting States shall by mutual agreement settle the mode of application of this limitation.

3. The term "interest" as used in this Article means income from debt claims of every kind, whether or not secured by mortgage and whether or not carrying a right to participate in the debtor's profits, and in particular, income from government securities and income from bonds or debentures, including premiums and prizes attaching to such securities, bonds or debentures. Penalty charges for late payment shall not be regarded as interest for the purpose of this Article.

4. The provisions of paragraphs 1 and 2 shall not apply if the beneficial owner of the interest, being a resident of a Contracting State, carries on business in the other Contracting State in which the interest arises, through a permanent establishment situated therein, or performs in that other State independent personal services from a fixed base situated therein, and the debt claim in respect of which the interest is paid is effectively connected with (a) such permanent establishment or fixed base, or with (b) business activities referred to in (c) of paragraph 1 of Article 7. In such cases the provisions of Article 7 or Article 14, as the case may be, shall apply.

5. Interest shall be deemed to arise in a Contracting State when the payer is a resident of that State. Where, however, the person paying the interest, whether he is a resident of a Contracting State or not, has in a Contracting State a permanent establishment or a fixed base in connection with which the indebtedness on which the interest is paid was incurred, and such interest is borne by such permanent establishment or fixed base, then such interest shall be deemed to arise in the State in which the permanent establishment or fixed base is situated.

6. Where, by reason of a special relationship between the payer and the beneficial owner or between both of them and some other person, the amount of the interest, having regard to the debt claim for which it is paid, exceeds the amount which would have been agreed upon by the payer and the beneficial owner in the absence of such relationship, the provisions of this Article shall apply only to the last-mentioned amount. In such case, the excess part of the payments shall remain taxable according to the laws of each
$O E C D M O D E L-2017$

1. Interest arising in a Contracting State and paid to a resident of the other Contracting State may be taxed in that other State.

2. However, interest arising in a Contracting State may also be taxed in that State according to the laws of that State, but if the beneficial owner of the interest is a resident of the other Contracting State, the tax so charged shall not exceed 10 per cent of the gross amount of the interest.

The competent authorities of the Contracting States shall by mutual agreement settle the mode of application of this limitation.

3. The term "interest" as used in this Article means income from debt-claims of every kind, whether or not secured by mortgage and whether or not carrying a right to participate in the debtor's profits, and in particular, income from government securities and income from bonds or debentures, including premiums and prizes attaching to such securities, bonds or debentures. Penalty charges for late payment shall not be regarded as interest for the purpose of this Article.

4. The provisions of paragraphs 1 and 2 shall not apply if the beneficial owner of the interest, being a resident of a Contracting State, carries on business in the other Contracting State in which the interest arises through a permanent establishment situated therein and the debtclaim in respect of which the interest is paid is effectively connected with such permanent establishment. In such case the provisions of Article 7 shall apply.

5. Interest shall be deemed to arise in a Contracting State when the payer is a resident of that State. Where, however, the person paying the interest, whether he is a resident of a Contracting State or not, has in a Contracting State a permanent establishment in connection with which the indebtedness on which the interest is paid was incurred, and such interest is borne by such permanent establishment, then such interest shall be deemed to arise in the State in which the permanent establishment is situated.

6. Where, by reason of a special relationship between the payer and the beneficial owner or between both of them and some other person, the amount of the interest, having regard to the debt-claim for which it is paid, exceeds the amount which would have been agreed upon by the payer and the beneficial owner in the absence of such relationship, the provisions of this Article shall apply only to the last-mentioned amount. In such case, the excess part of the payments shall remain taxable according to the laws of each Contracting State, due 
The taxation of income from interest follows a similar approach to that which is followed by the UN and the OECD regarding dividend taxation, notwithstanding the fact that both types of income stem from activities that are of a different nature. In both MTCs, Article 11 states that interest arising in a contracting state and paid to a resident of the other contracting state may be taxed in that other state. ${ }^{382}$

As in the case of dividends, the UN MTC does not specify the maximum interest withholding tax rate that the source country is permitted to apply. It left the threshold subject to negotiations between the prospective treaty partners. On the other hand, the OECD MTC stipulates a $10 \%$ maximum withholding tax rate on interest to the source country. The limit, considering the fact that interest is normally deductible at source, has never being clearly justified. Furthermore, even the London MTC which was influenced - and maybe more - by developed countries, did not establish a limitation on the withholding tax rate for the source country in advance. As was stated regarding dividends, in applying such a limitation on taxing interest, both MTCs require the beneficial owner of the interest to be resident in the other contracting state.

As stated in the UN MTC commentaries to this article, the UN MTC reproduces Article 11 of the OECD MTC with the exception of paragraphs two and four, both of which contain substantive differences, and paragraphs four and five regarding independent personal services.

Regarding paragraph two, the difference is that the UN MTC left the threshold of the withholding tax to be charged at source and subject to negotiations between prospective treaty partners, while the OECD MTC stipulates a fixed rate of $10 \%$ in this regard.

\footnotetext{
${ }^{382}$ United Nations, Department of Economic and Social Affairs, Model Double Taxation Convention between Developed and Developing Countries, 2017. Article 11.
} 
In paragraph four, which provides that paragraphs one and two do not apply to some kinds of interest, the UN MTC states two clear differences: firstly, the UN MTC, in paragraph 4 of Article 10, adds to the permanent establishment restrictions on applying paragraphs one and two and consequently application of Article 7 that if the beneficial owner, by being resident of a contracting state in which the interest arises, performs independent personal services in that other state from a fixed base situated therein, and the debt claim of which the interest is paid is effectively connected with such a fixed place, then the provisions of Article 14 will apply. Secondly, and since the UN MTC, unlike the OECD MTC, adopted a limited force of attraction rule in Article 7 - defining the income that may be taxed as business profits - 383 the corresponding change was made in Article 11 by adding that the inapplicability of paragraphs 1 and 2 are also extended to the case in which the debt claims are effectively connected with business activities in the source country of the same or a similar kind as those effected through the permanent establishment. ${ }^{384}$

Thirdly, regarding paragraph five, the only difference between the UN MTC and the OECD MTC is that in the UN MTC there is a reference to the "fixed base" concept as an addition to the "permanent establishment" concept. The above is related to the presumption that the source of the interest is in the contracting state of which the payer is resident, or, when not a resident, the payer has a permanent establishment or a fixed base connected with the indebtedness that created the interest payment.

\subsection{3 - TAXATION OF ROYALTIES}

\begin{tabular}{|c|c|}
\hline UN MODEL - 2017 & OECD MODEL - 2017 \\
\hline $\begin{array}{l}\text { 1. Royalties arising in a Contracting State and paid } \\
\text { to a resident of the other Contracting State may be } \\
\text { taxed in that other State. }\end{array}$ & $\begin{array}{l}\text { 1. Royalties arising in a Contracting State and } \\
\text { beneficially owned by a resident of the other Contracting } \\
\text { State shall be taxable only in that other State. }\end{array}$ \\
\hline $\begin{array}{l}\text { 2. However, such royalties may also be taxed in the } \\
\text { Contracting State in which they arise and according } \\
\text { to the laws of that State, but if the beneficial owner of } \\
\text { the royalties is a resident of the other Contracting } \\
\text { State, the tax so charged shall not exceed_ per cent } \\
\text { (the percentage is to be established through bilateral }\end{array}$ & $\begin{array}{l}\text { 2. The term "royalties" as used in this Article means } \\
\text { payments of any kind received as a consideration for the } \\
\text { use of, or the right to use, any copyright of literary, } \\
\text { artistic or scientific work including cinematograph films, } \\
\text { any patent, trade mark, design or model, plan, secret } \\
\text { formula or process, or for information concerning } \\
\text { industrial, commercial or scientific experience. }\end{array}$ \\
\hline
\end{tabular}

383 OECD, Model Tax Convention on Income and Capital, 2017. Article 7 paragraph 4.

${ }^{384}$ United Nations, Department of Economic and Social Affairs, Model Double Taxation Convention between Developed and Developing Countries, 2017. Commentary on Article 11 paragraph 4. 
negotiations) of the gross amount of the royalties. The competent authorities of the Contracting States shall by mutual agreement settle the mode of application of this limitation.

3. The term "royalties" as used in this Article means payments of any kind received as a consideration for the use of, or the right to use, any copyright of literary, artistic or scientific work including cinematograph films, or films or tapes used for radio or television broadcasting, any patent, trademark, design or model, plan, secret formula or process, or for the use of, or the right to use, industrial, commercial or scientific equipment or for information concerning industrial, commercial or scientific experience.

4. The provisions of paragraphs 1 and 2 shall not apply if the beneficial owner of the royalties, being a resident of a Contracting State, carries on business in the other Contracting State in which the royalties arise, through a permanent establishment situated therein, or performs in that other State independent personal services from a fixed base situated therein, and the right or property in respect of which the royalties are paid is effectively connected with (a) such permanent establishment or fixed base, or with (b) business activities referred to in (c) of paragraph 1 of Article 7. In such cases the provisions of Article 7 or Article 14, as the case may be, shall apply.

5. Royalties shall be deemed to arise in a Contracting State when the payer is a resident of that State. Where, however, the person paying the royalties, whether he is a resident of a Contracting State or not, has in a Contracting State a permanent establishment or a fixed base in connection with which the liability to pay the royalties was incurred, and such royalties are borne by such permanent establishment or fixed base, then such royalties shall be deemed to arise in the State in which the permanent establishment or fixed base is situated.

6. Where by reason of a special relationship between the payer and the beneficial owner or between both of them and some other person, the amount of the royalties, having regard to the use, right or information for which they are paid, exceeds the amount which would have been agreed upon by the payer and the beneficial owner in the absence of such relationship, the provisions of this Article shall apply only to the last-mentioned amount. In such case, the excess part of the payments shall remain taxable according to the laws of each Contracting State, due regard being had to the other provisions of this Convention.
3. The provisions of paragraph 1 shall not apply if the beneficial owner of the royalties, being a resident of a Contracting State, carries on business in the other Contracting State in which the royalties arise through a permanent establishment situated therein and the right or property in respect of which the royalties are paid is effectively connected with such permanent establishment. In such case the provisions of Article 7 shall apply.

4. Where, by reason of a special relationship between the payer and the beneficial owner or between both of them and some other person, the amount of the royalties, having regard to the use, right or information for which they are paid, exceeds the amount which would have been agreed upon by the payer and the beneficial owner in the absence of such relationship, the provisions of this Article shall apply only to the last-mentioned amount. In such case, the excess part of the payments shall remain taxable according to the laws of each Contracting State, due regard being had to the other provisions of this Convention

From an "allocation of taxing rights" perspective, Article 12 of the UN MTC is the only provision that addresses passive investment income that definitely departs from the OECD MTC approach. By providing a shared system of taxation between the source and the residence country, the UN MTC leaves behind the principle of the residence state's exclusive 
right to tax that is provided in the OECD MTC. ${ }^{385}$ Even though the OECD MTC does not follow this approach, it is important to consider Michael Lennard's ${ }^{386}$ statement: "This is an approach not provided for in Art. 12 of the OECD Model Convention itself, but which is followed by about half of the OECD Member countries and is therefore addressed in the Commentary to the OECD Model Convention on this Article".

Despite the foregoing, and as is stated in the UN MTC commentaries to this article, it reproduces Article 12 of the OECD MTC except for paragraphs one and three which contain substantive differences. Paragraphs two and five do not appear in the OECD MTC and paragraph four is drafted somewhat differently. The main differences between the models were stated in the UN MTC in $2014 .{ }^{387}$ Some of the most relevant points are reproduced below.

(1) In paragraph one, the difference is that the UN MTC provides a sharing system of taxation between the source and the residence country by dropping the word "only" from the corresponding provision contained in the OECD MTC. ${ }^{388}$

(2) Paragraph three reproduces paragraph two of the OECD MTC but includes the reference to equipment rental ${ }^{389}$ and includes, within the scope of royalty payments, tapes and films used for radio or television broadcasting which are not included in the corresponding OECD provision. The real relevance of the definition of royalties has more to do with competition between capital-importing countries (developing countries) and capital-exporting countries (developed countries) than with substantive implications. ${ }^{390}$ This simply demonstrates that the definition of royalties is conditioned on whether the countries concerned are considered to be technologyimporting or technology-exporting countries, instead of looking at the real nature of

\footnotetext{
385 Ibid., 385. Commentary on article 12 paragraphs 1 and 2.

${ }^{386}$ Lennard, Michael. The UN Model Tax Convention as compared with the OECD Model Tax Convention Current points of difference and recent developments. IBFD, Asia-Pacific Tax Bulletin, Vol 49, 2009.

${ }^{387}$ ECOSOC. Committee of Experts on International Cooperation in Tax Matters Twelfth Session, Discussion of substantive issues related to international cooperation in tax matters: article 12: general consideration, including equipment-related issues, 2014. Available at:

http://www.un.org/ga/search/view_doc.asp?symbol=E/C.18/2014/3\&Lang=E

$388 \mathrm{Ibid}, 388$.

${ }^{389}$ Amendment done to the OECD MTC in 1992.

${ }^{390}$ García Heredia, Alejandro. The definition of Royalties in International Tax Law: The copyright, industrial and know-how, Spain, University of Oviedo, EATTA Prizewinner, 2007. Available at: https://ec.europa.eu/taxation_customs/sites/taxation/files/docs/body/taxthesisaw(garciaheredia).pdf
} 
the income. Thus, capital-importing countries defend a narrower concept of royalties so that the country of use of the intellectual (including industrial) property has a right to tax more profits than the country where the intellectual property owner is resident, ${ }^{391}$ and the capital-exporting countries (the country where the intellectual property owner is resident) are interested in a broad conception of royalties so that they can levy more tax.

(3) Paragraph two is a consequence of the approach followed in paragraph one, which is that royalties may be taxable in the source country as well as in the residence country. Thus, this paragraph limits the withholding tax to be imposed by the source country on the gross amount of the royalties up to a certain threshold that is to be negotiated between the prospective treaty partners, which in turn is underpinned by the fact that the beneficial owner of the royalties is a resident of the other contracting state.

(4) Paragraph five, which is also a consequence of the approach followed in paragraph one, includes a presumption that the source of the royalty income is in the contracting state of which the payer is resident, or, when not a resident, where the payer has a permanent establishment or a fixed base connected with which the liability to pay the royalties is incurred.

(5) In paragraph four of the UN MTC and paragraph three of the OECD MTC, the only difference between the UN MTC and the OECD MTC is that in the UN MTC there is a reference to the "fixed base" concept as an addition to the "permanent establishment" concept. This is related to the restrictions on applying paragraphs one and two - in the OECD Model only paragraph one - and consequently the application of Articles 7 and 14 respectively - in the OECD Model only Article 7 - if the beneficial owner of the royalties, as a resident of a contracting state, carries on business in the state where the royalties arise through a permanent establishment situated therein or performs, in that other state, independent personal services from a fixed base situated therein.

\footnotetext{
${ }^{391}$ Lennard, Michael. The UN Model Tax Convention as compared with the OECD Model Tax Convention Current points of difference and recent developments. IBFD, Asia-Pacific Tax Bulletin, Vol 49, 2009.
} 
According to several UN Member States, the inequitable distribution of income between "source" and "residence" countries needs to be rebalanced in favour of "source" countries. As a consequence, in the UN works, one of the main issues is how to increase "source" country taxation. The committee referred to a number of alternatives to do so, including a services permanent establishment provision and a broader scope to the royalty definition than that which is included in the OECD MTC. The current trend seems to be the inclusion of all forms of tangible assets instead of the odd classification of industrial, commercial or scientific equipment, ${ }^{392}$ which goes far beyond the proposals made with respect to the royalty article in $2016 .^{393}$

392 ECOSOC. Committee of Experts on International Cooperation in Tax Matters Twelfth Session, Possible Amendments to the Commentary on Article 12 (Royalties), Note by the Coordinator, Ms. Pragya Saksena, 2014. Available at: https://www.un.org/esa/ffd/wp-content/uploads/2016/10/12STM_CRP8_Royalties.pdf ${ }^{393}$ Ibid., 390. 


\section{PART III. UPDATING THE DEBATE}

\subsection{CONTEXTUALIZATION OF THE MATTER}

For more than a century, governments and tax specialists have relied on DTCs. The expectations that come with these types of treaties are of the most varied character. Initially, the intention was to avoid double taxation. However, a number of other functions have come into the equation since then. For instance, DTCs are considered to be indispensable instruments for the exchange of information with the aim of controlling international tax fraud. In this regard, organizations such as the OECD consider the existence of a DTC as a determinative factor when defining whether a jurisdiction is cooperative, non-cooperative or a tax haven. ${ }^{394}$ It is also claimed that DTCs help to attract foreign investment ${ }^{395}$ and that they grant legal and investment protection to foreign investors. Lastly, and one role that becomes more important each and every day, is the ability of DTCs to resolve conflicts which arise when two jurisdictions disagree on the interpretation or application of a provision in a DTC. The mutual agreement procedure (MAP) was extensively revised in the BEPS Project. ${ }^{396}$ Developing countries believe that DTCs help to increase economic growth and foster economic development. They have been signing such treaties for more than 30 years. Although DTCs alone cannot determine the success of economic growth and development, they can nevertheless aid in this process.

\footnotetext{
${ }^{394}$ Lang, Michael; Pistone, Pasquale; Schuch, Josef; Staringer, Claus; Storck, Alfred; and Zagler, Martin. Tax Treaties: Building Bridges between Law and Economics. IBFD, 2010. As quoted in that book, this kind of pressure is being put by the Global Forum on Fiscal Transparency.

${ }^{395}$ United Nations, Department of Economic and Social Affairs, Division for Public Administration and Development Management, Manual for the Negotiation of Bilateral Tax Treaties between Developed and Developing Countries, New York, 2019. Preface.

396 OECD, Making Dispute Resolution Mechanisms More Effective, 2015. Available at: http://www.oecd.org/tax/making-dispute-resolution-mechanisms-more-effective-action-14-2015-final-report9789264241633-en.htm; The Action 14 of the BEPS Project focused on making dispute resolution mechanisms more effective by developing solutions to address obstacles that prevent countries from solving treaty disputes under MAP. This was due to the absence of arbitration provisions in most treaties and the fact that access to MAP and arbitration may be denied in certain cases. The proposals for change were included in the draft for the 2017 OECD MTC, Available at: http://www.oecd.org/ctp/beps/oecd-releases-draft-contents-2017-updatemodel-tax-convention.htm. The focus is centred on allowing taxpayers to submit a case for MAP to the competent authority of either Contracting State, as opposed to the previous wording which only permitted that taxpayers present MAP cases to the competent authorities of their countries of residence.
} 
As is revisited in this work, the weak connection between the increase in foreign investment and DTCs is clear. ${ }^{397}$ This was not evident during the second half of $20^{\text {th }}$ century, however. As was stated, the positive evolution of unilateral measures to eliminate juridical double taxation changed the role of DTCs in this respect. Thus, and regarding the incomes analysed in this work, developing countries end up waiving revenue in their DTCs with developed countries without necessarily receiving any reciprocal economic benefits. DTCs are used, and imposed on developing countries, as tools to enhance the international image of developed countries. ${ }^{398}$

The principle of non-discrimination according to nationality or other precise circumstances, as is stipulated in Article 24 of the MTC, is part of the scope of legal and investment protection for foreign investors. ${ }^{399}$ This principle implies that countries cannot subject a national of a treaty partner country to more burdensome taxation than its own nationals who face the same circumstances and have the same residential status for tax purposes. There are other forms of tax discrimination that are also dealt with in DTCs, for example: (1) permanent establishments of a treaty partner enterprise may not be subjected to more burdensome taxation than a local enterprise carrying on the same activities; (2) stateless persons must be provided equality of treatment with the nationals of a country and (3) the payment of interest, royalties or other disbursements by a resident enterprise to a resident of a treaty partner country must be deductible under the same conditions as if they had been paid to a local resident. ${ }^{400}$ All of these measures are designed to prevent discrimination, which is also an important effect of DTCs.

The granting of legal certainty and investment protection to foreign investors and the elimination of double taxation are, in the majority of the cases, already covered by a

\footnotetext{
${ }^{397}$ Davies, Ronald B. Tax Treaties, Renegotiations, and Foreign Direct Investment. Economic Analysis and Policy, Vol 33, 2003. Available at: http://citeseerx.ist.psu.edu/viewdoc/download?doi=10.1.1.519.7883\&rep=rep1\&type=pdf

398 OECD, Global Forum on Transparency and Exchange of Information for Tax Purposes, 2009. Information available at: http://www.oecd.org/tax/transparency/

${ }^{399}$ United Nations, Department of Economic and Social Affairs, Model Double Taxation Convention between Developed and Developing Countries, 2017. Commentary on Article 24 paragraph 1.

400 Pickering, Ariane. Why Negotiate Tax Treaties?. 2013 Available at: http://www.un.org/esa/ffd/wpcontent/uploads/2013/05/20130530_Paper1N_Pickering.pdf.
} 
combination of domestic legislation and Bilateral Investment Treaties (BITs). ${ }^{401}$ Reuven Avi-Yonah, in his work entitled "Double Tax Treaties: An Introduction", states that DTCs are generally unnecessary for preventing double taxation, since most countries unilaterally prevent double taxation by either exempting foreign income or by granting a foreign income tax credit. $^{402}$

Developing countries claims regarding their taxing rights on dividends, interest and royalty income have been related neither to the increase of foreign investment nor to incentives to have access to useful foreign equity, debt capital and necessary technology from developed to developing countries. The UN approach has been focused on: (1) increasing the rights compared to those granted to the source country in the OECD MTC, i.e. royalty income; and (2) the expectation that treaty negotiations between developing and developed countries will result in granting higher withholding tax rates to the source country than those that are normally applied in DTCs between two developed countries. ${ }^{403}$

In the work published in 2014 by professors Lang and Owens, ${ }^{404}$ they insist in relation to DTCs that withholding taxes, and therefore revenue, are key instruments for facilitating development. However, and as those authors correctly conclude, the negotiation of DTCs only creates a more stable and certain climate in which FDI can take place. Moreover, that work reaffirmed that the main objectives that developing countries can expect to achieve when signing a DTC with a developed country are: the elimination of double taxation, certainty and predictability, non-discrimination, mechanisms to minimize and resolve tax disputes and the division of the tax base according to the rules drafted in the DTC.

401 UNCTAD. The role of International Investment agreements in attracting foreign direct investment to developing countries, New York and Geneva, 2009. Available at: http://unctad.org/en/Docs/diaeia20095 en.pdf

402 Avi-Yonah, Reuven S. Double Tax Treaties: An Introduction. University of Michigan Law School, 2007. Available at: http://papers.ssrn.com/sol3/papers.cfm?abstract_id=1048441.

${ }^{403}$ United Nations, Department of Economic and Social Affairs, Model Double Taxation Convention between Developed and Developing Countries, 2017. Articles 10, 11 and 12.

${ }^{404}$ Lang, Michael; and Owens, Jeffrey. The role of tax treaties in facilitating development and protecting the tax base. WU International Taxation Research, Paper Series No. 2014-03 
The premise of developed countries regarding their preliminary rights to tax passive investment income when acting as home/resident countries is not correct. Both the OECD MTC and the UN MTC allocate passive investment income to the country of residence. Stating that the country of residence is giving up taxing rights whilst signing a DTC with a developing country is not accurate. All countries are, in most cases, bound by their own domestic legislation, namely to avoid double taxation. Therefore, if we compare the rights to tax of a developed country in their commercial relations with developing countries before signing a DTC to the situation once the DTC is actually signed, the conclusion will be, in the majority of cases, that the developed country has increased its taxing rights as a consequence of the DTC.

Following the same line of reasoning, it could be argued that developing countries have not realized that they need a superior goal before they can give up their taxing rights. Effects such as the elimination of double taxation, certainty and predictability, non-discrimination, mechanisms to minimize and resolve tax disputes and the division of the tax base according to the rules drafted in the DTC, can be granted domestically, and therefore, the economic sacrifice that those countries are currently making is not justified.

The ongoing discussions disregard the fact that DTCs must bring benefits to both signatory countries. The granting of reciprocal benefits is the only argument that could validate subscription to a DTC. The relationship between DTCs, tax incentives for foreign investors and the short-term budgetary damage of the host / source country - developing country - is therefore direct.

The international flow of investments from developed to developing countries has increased over the last 50 years and, consequently, taxing rights have shifted from developing to developed countries due to the increase of DTCs that have been signed between them. There is no scientific proof that the order of the factors has been first, the signing of DTCs, and second, the increase of foreign investment in the host / source developing country. This parallel evolution is mostly caused by the worldwide tendency of countries to open their markets to foreign investors. DTCs are not the reason for the increase in cross-border 
investments. The causal relationship between DTCs and the increase of foreign investment is therefore inconsistent. 405

Professor Klaus Vogel, in his publication “Double Tax Treaties and Their Interpretation”, 406 opined that unilateral measures alone are insufficient to avoid double taxation because they generally do not cover all of the situations that give rise to double taxation and they may apply inconsistently to double taxation situations depending on which states' measures are applied. From that starting point, he justified why countries have entered into bilateral agreements since the 1920s. Nowadays the situation is rather different. The main consequence of modern DTCs is to shift taxing rights away from capital-importing countries to capital-exporting countries. ${ }^{407}$

In the report issued by David A. Ward for the Advisory Panel on Canada's System of International Taxation in 2008, it was stated that "the purpose of avoiding double taxation is therefore probably no longer the dominant purpose of many tax treaties". ${ }^{08}$ Ward even stated that in 1992, and due to the above, the OECD changed the title of the MTC: dropping the reference to "Double Taxation Convention" and replacing it with "Tax Convention".

In the same line of reasoning, Katrin McGauran, in her publication "Should the Netherlands sign tax treaties with developing countries?", which was published by the Center for Research on Multinational Corporations as part of a series of publications analysing the impact of Dutch foreign and economic policy on sustainable development and public interest, ${ }^{409}$ explicitly addressed the changing role of DTCs in this respect. This research began

\footnotetext{
${ }^{405}$ McGauran, Katrin. Should the Netherlands Sign Tax Treaties with Developing Countries? Amsterdam, 2013 available at: https://www.somo.nl/wp-content/uploads/2013/06/Should-the-Netherlands-sign-tax-treaties-withdeveloping-countries.pdf

${ }^{406}$ Vogel, Klaus, Double Tax Treaties and Their Interpretation. International Tax \& Business Lawyer, Vol 4, 1986.

${ }^{407}$ Lang, Michael; Pistone, Pasquale; Schuch, Josef; Staringer, Claus; Storck, Alfred; and Zagler, Martin. Tax Treaties: Building Bridges between Law and Economics. IBFD, 2010.

${ }^{408}$ Ward, David. Access to Treaty Benefits. Research Report Prepared for the Advisory Panel on Canada's System of International Taxation, 2008. Available at: https://www.fin.gc.ca/access/tt-it/apcsitgcrcfi/pdf/RR12\%20-\%20Ward\%20-\%20en\%20-\%20final\%20-\%20090618.pdf

${ }^{409}$ McGauran, Katrin. Should the Netherlands Sign Tax Treaties with Developing Countries? Amsterdam, 2013 available at: https://www.somo.nl/wp-content/uploads/2013/06/Should-the-Netherlands-sign-tax-treaties-withdeveloping-countries.pdf
} 
from the assumption that, although exceptions might still exist and some states might still want to agree on mechanisms to eliminate double taxation in a DTC rather than introducing domestic laws, these individual cases do not justify the existence of a DTC network which consists of more than 3,000 treaties.

Victor Thuronyi's work entitled "Tax Treaties and Developing Countries", 410 which constituted Part VI of the research project of the Institute for Austrian and International Tax Law from the Vienna University of Economics and Business, named "Tax Treaties: Building Bridges between Law and Economics", goes even further. He stated that most of the results of DTCs can be similarly accomplished by adopting unilateral measures, and he concluded that, notwithstanding that DTCs provide some degree of legal protection, if we consider what can be accomplished by unilateral measures, the additional value from the legal protection afforded by a DTC in many cases will not be worth the cost of negotiating that DTC in the first place.

The work conducted by Tsilly Dagan, "The Tax Treaties Myth", ${ }^{411}$ started by asking: "What is the objective of DTCs?" The answer, and the starting point of that research, was "one might say that the point is to prevent, or at least relieve double taxation. But this objective is a myth".

For David A. Ward, the only effect is that DTCs should now be regarded as agreements that: (1) allocate, between the state of source and the state of residence, the right to tax specific types of income; (2) assist tax authorities by reducing tax evasion, providing information to assess taxes, assist in collecting taxes across borders and deal with tax avoidance schemes; and (3) assist taxpayers by removing obstacles to the development of economic relations between countries for taxpayers engaged in commercial, industrial, financial or other activities, including settling, on a uniform basis, the most common problems that arise in the field of international taxation.

\footnotetext{
410 Thuronyi, Victor. Tax Treaties and Developing Countries in Tax Treaties: Building Bridges between Law and Economics. IBFD, 2010

${ }^{411}$ Dagam, Tsilly. The tax treaties myth. New York University Journal of International Law and Politics, Vol $32,2000$.
} 
Katrin McGauran concluded that, due to the failure of the UN MTC, developing countries were confronted with already existing internationally accepted tax treaty standards which reflected the interests of OECD countries. Therefore, and with the understanding that the OECD tax treaty network provides advantages for members of that network, developing countries signed DTCs within the OECD parameters. The advantages of doing so were the minimization of communication and the enforcement costs or reputational advantages for FDI over competitors who are not members of that tax treaty network.

Victor Thuronyi proposed, as a solution, that if there is a particular investment project, e.g. a mining project, where tax stability and other aspects of the legal regime are important as a matter of encouraging investment, this can often be accomplished more effectively by a concluding a specific agreement with the taxpayer concerned. Thuronyi specifically stated that legal certainty surrounding taxation can be provided by written rulings, thus clarifying how tax law is to be interpreted and applied in specific cases. Regarding the lack of administrative capacity to issue a substantial number of such rulings, he proposed charging a fee for rulings, thereby providing the resources to hire the necessary staff, while also providing an incentive to keep the number of rulings down.

And lastly, Tsilly Dagan proved that, due to the incentives that countries have, if each country were to implement a unilateral policy for the purposes of preventing double taxation, the interaction between the unilateral policies of the residence and the host country would result in a stable equilibrium in which juridical double taxation would, as a matter of fact, be alleviated.

Of these research projects, only that of David A. Ward and of Victor Thuronyi actually considered the increase of foreign investments in the host country as an important element. As professors Ault and Arnolds stated in their work on the protection of the tax base of developing countries, ${ }^{412}$ it is not possible to predict the effects of the BEPS Report on tax

\footnotetext{
${ }^{412}$ Ault, Hugh J; and Arnolds, Brian J. Protecting the Tax Base of developing countries. Chapter I of the United Nations Handbook on Selected Issues Edited by Alexander Trepelkov, Harry Tonino and Dominika Halka, New
} 
incentives. However, if the project succeeds, the tax incentives offered by developing countries and, in the case of this work, by DTCs concluded between developing and developed countries may become more attractive for foreign investors. The above is understood in the context that foreign multinational enterprises will face more difficulties in stripping profits out of developing countries. ${ }^{413}$ Moreover, it should not be disregarded that corporate taxation on inbound investments plays a larger role in the total revenue of developing countries. ${ }^{414}$ The taxation of passive investment income should therefore be regulated in order to grant the right to impose tax incentives, and they should not interfere in the taxation of business income for enterprises that are incorporated in developing countries but which are owned by foreign investors.

\subsubsection{EUROPEAN UNION EXPERIENCE}

Although at DTC level it is not a recognized policy, with the exception of the treatment of income from royalties in the OECD MTC, a good example of measures designed to eliminate tax obstacles in a specific market are those promulgated by the EU. Although such measures are specifically designed for a regional economy, it is nevertheless worth considering them here.

The EU implemented an approach that grants the total elimination of withholding taxes at source, and therefore of juridical and economic double taxation, as a valid measure regarding dividend income and it has done so since the adoption of the Parent-Subsidiary Directive in July $1990 .{ }^{415} 416$ Following the same reasoning, but regarding the elimination of juridical

York, 2017. Available at: https://www.un.org/esa/ffd/wp-content/uploads/2017/08/handbook-tax-base-secondedition.pdf

413 Ibid, 413 .

414 Ibid, 413.

${ }^{415}$ Council Directive (EU), 1990/435/EEC, July 23, 1990, on the common system of taxation applicable in the case of parent companies and subsidiaries of different Member States.

${ }^{416}$ Council Directive (EU), 2003/123/EC, December 22, 2003, amending Directive 90/435/EEC on the common system of taxation applicable in the case of parent companies and subsidiaries of different Member States. 
double taxation regarding interest and royalties, was the issuance of the Interest and Royalty Directive in June 2003. ${ }^{417}$

The Parent-Subsidiary Directive was designed to eliminate tax obstacles in the area of profit distributions between groups of companies in the EU. This was to be done by abolishing withholding taxes on the payment of dividends between associated companies of different EU Member States and by preventing the economic double taxation of parent companies on the profits of their subsidiaries. This applies to dividends distributed by subsidiaries to their controlling parent companies. As of 1 January 2009, the holding percentage to qualify as a controlled subsidiary is at least $10 \%$ of the capital of that subsidiary. The Parent-Subsidiary Directive, in its preamble, states that the Directive was justified since, at that time, tax provisions which governed the relations between parent companies and subsidiaries of different Member States varied greatly from one Member State to another. It was also the case that those provisions were generally less advantageous than those applicable to parent companies and subsidiaries of the same Member State, which naturally constituted a disadvantage to cooperation between the companies of different Member States compared to the cooperation between companies of one Member State. The measures introduced by the Directive resulted in exempting dividend distributions from withholding taxes in the host / source country and eliminating both international juridical and economic double taxation in the state home/residence country of the parent company, either by exempting the dividends received from taxation or by granting a tax credit (indirect tax credit) in respect of any foreign taxation incurred on the relevant profits. Article 5 of the Directive states that: "Profits which a subsidiary distributes to its parent company shall be exempt from withholding tax." and Article 4(1) of the Directive states that:

Where a parent company or its permanent establishment, by virtue of the association of the parent company with its subsidiary, receives distributed profits, the Member State of the parent company and the Member State of its permanent establishment shall, except when the subsidiary is liquidated, either:

${ }^{417}$ Council Directive (EU), 2003/49/EC, June 3, 2003, on a common system of taxation applicable to interest and royalty payments made between associated companies of different Member States. Article 3 letter b). 
(a) refrain from taxing such profits; or

(b) tax such profits while authorizing the parent company and the permanent establishment to deduct from the amount of tax due that fraction of the corporation tax related to those profits and paid by the subsidiary and any lower-tier subsidiary, subject to the condition that at each tier a company and its lower-tier subsidiary fall within the definitions laid down in Article 2 and meet the requirements provided for in Article 3, up to the limit of the amount of the corresponding tax due.".

This Directive was implemented by the 28 EU Member States and most of them follow the participation exemption option as the most suitable method for the elimination of double taxation. In some specific cases, e.g., in Austria, if there is an abuse of law, the method switches from the exemption to the indirect credit method. The Netherlands also provides for a switchover in the case of low-taxed or non-active participations. The abuse of law can also lead to the non-application in the Parent Subsidiary Directive regime, e.g. in the case of France. Thus, also considering the prohibition on taxing dividends on a second tier at source, the outcome is a market that taxes dividends on a second tier neither at source nor at residence, i.e. double juridical non-taxation. On 27 January 2015, the European Council formally adopted a binding general anti-abuse rule, i.e. through a main purpose test, to be included in the Parent-Subsidiary Directive. ${ }^{418}$

The Interest and Royalty Directive was designed to eliminate tax obstacles in the area of cross-border interest and royalty payments within a group of companies in the EU by

\footnotetext{
${ }^{418}$ Article 1 paragraph 2 of the Directive was replaced by the following paragraphs:

"2.Member States shall not grant the benefits of this Directive to an arrangement or a series of arrangements which, having been put into place for the main purpose or one of the main purposes of obtaining a tax advantage that defeats the object or purpose of this Directive, are not genuine having regard to all relevant facts and circumstances.

An arrangement may comprise more than one step or part.

3. For the purposes of paragraph 2, an arrangement or a series of arrangements shall be regarded as not genuine to the extent that they are not put into place for valid commercial reasons which reflect economic reality.

4. This Directive shall not preclude the application of domestic or agreement-based provisions required for the prevention of tax evasion, tax fraud or abuse."
} 
abolishing withholding taxes on interest and royalty payments arising in a Member State. These interest and royalty payments are exempt from any tax at source provided that the beneficial owner of the payment is a company or a permanent establishment that is resident in another Member State. Similar to the Parent-Subsidiary Directive, the preamble to the Interest Royalty Directive states that in a single market having the characteristics of a domestic market, transactions between companies of different Member States should not be subject to less favourable tax conditions than those applicable to the same transactions carried out between companies of the same Member State. This requirement was not met in relation to interest and royalty payments; national tax laws coupled, where applicable, with bilateral or multilateral agreements may not always ensure that double taxation is eliminated, and their application often entails burdensome administrative formalities and cashflow problems for the companies concerned. With an equivalent aim as that of the Parent-Subsidiary Directive, but in this case regarding interest and royalties, and aiming to put cross-border interest and royalty payments on an equal footing with domestic payments, by eliminating juridical double taxation and cashflow disadvantages, the Interest and Royalties Directive exempts interest and royalty payments from withholding tax by the host / source country and allows the home/residence country of the recipient to tax that income. Article 1 of the Directive states that: "Interest or royalty payments arising in a Member State shall be exempt from any taxes imposed on those payments in that State, whether by deduction at source or by assessment, provided that the beneficial owner of the interest or royalties is a company of another Member State or a Permanent Establishment situated in another Member State of a company of a Member State". Article 7 of the Directive states that this Directive "(...)shall apply only if the company which is the payer, or the company whose permanent establishment is treated as the payer, of interest or royalties is an associated company of the company which is the beneficial owner, or whose permanent establishment is treated as the beneficial owner, of that interest or those royalties". The shareholding requirement to establish that companies are associated is defined as a $25 \%$ direct holding. ${ }^{419}$

\footnotetext{
${ }^{419}$ Council Directive (EU), 2003/49/EC, June 3, 2003, on a common system of taxation applicable to interest and royalty payments made between associated companies of different Member States. Article 3 letter $b$ ).
} 
As in the case of dividend income, regarding interest and royalties, the EU began from the premise that interest and royalty payments should be subject to tax, economically speaking, only once. The formal difference in the tax treatment (dividends, exempted from tax at a second tier at host / source and indirect credit or exemption at home / residence versus interest and royalty payments exempted at host / source and taxed at home/residence) is the result of the traditional domestic treatment of those types of income. Although dividends are not taxed at a second tier at source, they are economically taxed in the form of business profits at first tier at source, i.e. corporate level - business profits. The Directive aims to avoid economic double non-taxation. Thus, in the case of dividends, despite there being juridical double nontaxation, the income is still only taxed once. The same is intended regarding interest and royalties. Since both interest and royalties are deductible expenses for the payer at source, there is eventually only one tier of taxation at source (withholding tax) and one tier of taxation at residence. The Interest and Royalty Directive opted for the elimination of taxation at source (no withholding tax) and only leaves taxation at residence, complying with the rule of being economically taxed once, which in turn neither affects nor discriminates against the flow of taxes in the EU market.

Although not comparable, the situation of two countries within the same market, with one of a developing and one of a developed country that do not form part of the same common market, the approach is absolutely valid for the purposes of this research. The ParentSubsidiary Directive conceives of the non-taxation at source neither at residence "double juridical non-taxation" as a benefit nor as a problem. Those criteria are commensurate with the idea of solving the lack of incentives for home / resident countries' investors to invest in host / source developing countries when applying the UN MTC. Thus, according to this line of reasoning, the premise "harmful effect of economic double non-taxation" should be carefully respected.

One demonstration of the premise mentioned above, as an international tax principle, came in December 2012 when the European Commission published an action plan on tax fraud and evasion, which included proposals to address the perceived loopholes in the EU ParentSubsidiary Directive. The aim of the European Commission was to incorporate an anti- 
avoidance rule in the Directive by excluding payments on cross-border hybrid loans from a tax exemption. By doing so, the Parent-Subsidiary Directive avoided the existence of economic double non-taxation, i.e. business profits must be subject to tax only once. Thus, the aim is to prevent the Directive from facilitating economic double non-taxation arising from hybrid loan structures, e.g. where a loan is treated as debt at source and as equity at residence, whereby payments on the loan are deductible in the former and exempt in the latter. The same objective - measures to avoid the harmful effect of economic double nontaxation - can be found in the BEPS project, in which the EU, the OECD and the UN have been either directly or indirectly involved.

\subsubsection{TAX SPARING CLAUSES / MATCHING CREDITS}

Tax sparing provisions are the mechanism used by DTCs - based on the UN MTC - to preserve the tax incentives granted by one jurisdiction, which are normally developing or less developed countries. They require the other jurisdiction, which is normally the developed country, to grant a tax credit for the taxes that would have been paid if the incentive had not been granted. ${ }^{420}$ In practice, this operates as a tax exemption for the parent company in the home / resident country and it is based on the statutory tax rate that is in force in the host / source country. ${ }^{421}$ The commentaries to Article 23 of the UN MTC define tax sparing as a credit granted in respect of a tax that is not only actually paid but which has actually been forgone under the incentive legislation. Most of the DTCs concluded by developed countries, with the exception of the United States, with many but not all developing countries contain tax sparing provisions. ${ }^{422}$

\footnotetext{
${ }^{420}$ Brooks, Kim. Using the Tax System to Promote Investment in Low-Income Countries: An illustration of good intentions, bad results in Globalization and the Impact of Tax on International Investments: A Symposium in Honour of the Memory of the Late Alex Easson, Queen's University, 2008.

${ }^{421}$ Lejour, Arjan. The foreign investment effects of tax treaties. CPB Netherlands Bureau for Economic Policy Analysis, 2014.

${ }^{422}$ Hines, James R. Jr. Tax Sparing and Direct Investment in Developing Countries in International Taxation and Multinational Activity, University of Chicago Press, 2000. Available at: http://www.nber.org/chapters/c10719.pdf
} 
Tax sparing provisions play their most important role in cases in which the foreign investor is taxed in its state of residence on the income that is earned in the source country developing country - in the year that the profits were earned. ${ }^{423}$ Thus, the effectiveness of tax sparing rules do not solely depend on the relevant provisions, as is normally believed to be the case. There are certain cases in which the provisions lose their meaning, however. One case is when the investor carries on the business through a separately incorporated entity that is resident in the source country. In such a case, the investor will not be taxed in relation to that income by his residence country. Using the same example, but regarding dividend distributions, if the residence country of the investor adopts an exemption approach that does not tax income earned in the source country at all, then it follows that tax-sparing provisions will also lose their meaning.

Matching credit clauses are mechanisms that look to the same objectives as tax sparing, which is regarded as the main type of tax sparing clauses. ${ }^{424}$ The difference between them depends on the level of influence of the unilateral measures that have been taken by the source state to be effective. On the one hand, tax sparing clauses are mechanisms that aim to increase foreign investment by leaving such a decision in the hands of the source country. Thereby, if the source country were to tax up to a determined level, the resident country, under the treaty or through unilateral measures, would grant a foreign tax credit for the tax. However, where the source state decides not to tax its non-resident up to the limit that was granted to it by the treaty, the residence state must respect such a decision and grant a credit equivalent to the maximum amount that the source state could have taxed. Therefore, these clauses only benefit investors if the source state unilaterally decides to reduce its taxes, which implies taxation below the level permitted by the treaty. ${ }^{425}$

On the other hand, matching credits are mechanisms that aim to increase foreign investment through bilateral consensus. Thereby, if the source state decides not to tax non-residents at

\footnotetext{
${ }^{423}$ Brooks, Kim. Using the Tax System to Promote Investment in Low-Income Countries: An illustration of good intentions, bad results in Globalization and the Impact of Tax on International Investments: A Symposium in Honour of the Memory of the Late Alex Easson, Queen's University, 2008.

${ }^{424}$ Vogel, Klaus. Klaus Vogel on Double Taxation Conventions, $3^{\text {rd }}$ ed., 1997.

425 Schoueri, Luis Eduardo. Tax sparing: a reconsideration of the reconsideration in Tax. Law and Development, edited by Brauner, Yariv; and by Stewart, Miranda. Edward Elgar Publishing, 2013. p. 111.
} 
more than the level that is fixed between the two contracting states, the residence country agrees to grant a foreign tax credit that will correspond to a fixed amount, usually higher than the maximum taxation in the source state. Such a benefit is stated in the treaty and it will therefore take effect independent of the unilateral measures or decisions of the source country. 426

The UN's recognition of tax sparing clauses as effective methods to avoid the nullification of developing countries incentives was not the general consensus from the outset. The UN's Guidelines for Tax Treaties between Developed and Developing Countries issued by the UN Department of Economic and Social Affairs in 1974 stated that the problem of tax sparing was one of the important issues before that group. The group abided by the recommendation of the Secretariat, recognizing that alternatives should be considered because not all developed countries considered it appropriate to grant a tax sparing credit. ${ }^{427}$

The UN MTC was released in 1980 and, although it was designed to be more favourable for low-income countries entering into tax treaties with high-income countries, the MTC did not go so far as to include a provision supporting tax sparing provisions. ${ }^{428}$ It was only in the observations to Article 23 where it was stated that "(...) the most effective method of preserving the effects of the tax incentives and concessions extended by developing countries would be the application of a tax sparing credit". Nowadays the UN refers to tax sparing in the commentaries to Article 23, describing it as the wish of states that adopted incentive programs. ${ }^{429}$ The statement - an effective method to avoid the nullification of developing countries incentives - has been examined elsewhere. ${ }^{430}$ However, there is no empirical

\footnotetext{
${ }^{426}$ Ibid, 426.

427 United Nations, Department of Economic and Social Affairs, Guidelines for Tax Treaties Between Developed and Developing Countries, New York, 1974. 2016 version available at: https://www.un.org/esa/ffd/wp-content/uploads/2016/05/manual_btt.pdf

${ }^{428}$ Brooks, Kim. Using the Tax System to Promote Investment in Low-Income Countries: An illustration of good intentions, bad results in Globalization and the Impact of Tax on International Investments: A Symposium in Honour of the Memory of the Late Alex Easson, Queen's University, 2008.

${ }^{429}$ United Nations, Department of Economic and Social Affairs, Model Double Taxation Convention between Developed and Developing Countries, 1980. United Nations, commentary on article 23.

${ }^{430}$ Hines, James R. Jr. Tax Sparing and Direct Investment in Developing Countries in International Taxation and Multinational Activity, University of Chicago Press, 2000. P. 64. "Japanese firms are significantly more likely than U.S. firms to concentrate their outbound FDI, and its equity component, in countries with whom Japan has tax sparing agreements". Available at: http://www.nber.org/chapters/c10719.pdf
} 
evidence as to whether the increased level of foreign investment created by tax incentives and tax sparing provides any development benefit for the host country. ${ }^{431}$

The discussion of the influence of these rules on foreign investment and therefore on the development of developing or less developed countries has lost its strength. An interesting conclusion was written by professor Luis Eduardo Schoueri in his work entitled "Tax sparing: a reconsideration of the reconsideration", part of the book "Tax, Law and Development" that was edited in 2013 by professors Yariv Brauner and Miranda Stewart. That article introduced the idea that these types of clauses are more related to sovereignty than to development, concluding that they must be seen as an element of treaty negotiations which aim to respect each contracting state's tax policies and it is on this basis that their adoption should be encouraged. Moreover, the article also gives arguments for applying these mechanisms in all tax treaties, not only in treaties between developing and developed countries but also in treaties between developed countries. Thus, it can be understood as an incentive to foreign investors but with non-direct effect in the development of the source developing country.

The rationale behind tax incentives is that they are good measures for developing countries, though this is only the case if the sacrifice of tax revenue is justified by the increase of foreign investment that would not occur without the incentive. ${ }^{432}$ The OECD stated that, regarding FDI, the main benefit for developing countries lies in its long-term contribution to integrating the host economy more closely with the world economy. ${ }^{433}$ The OECD has also recognized that FDI triggers technology spillovers, assists human capital formation, contributes to international trade integration, helps create a more competitive business environment and enhances enterprise development. ${ }^{434}$

\footnotetext{
${ }^{431}$ Barker, William B. An International Tax System for Emerging Economies, Tax Sparing, and Development: It Is All about Source. University of Pennsylvania Journal of International Law, Vol 29, 2007. Available at: http://scholarship.law.upenn.edu/cgi/viewcontent.cgi?article=1163\&context=jil.

${ }^{432}$ Haugland, Kristian R. The Concept of Tax Sparing A General Analysis, and an Analysis and Assessment of the Various Features of Tax Sparing Provisions, Master's Thesis headed by Professor Frederik Zimmer, University of Oslo, 2013. Available at: http://www.jus.uio.no/ior/english/research/projects/global-taxtranparency/publications/the-concept-of-tax-sparing.pdf

${ }^{433}$ OECD, Foreign Direct Investment for Development. Maximising Benefits, Minimising Costs. Overview 2002. Available at http://www.oecd.org/investment/investmentfordevelopment/1959815.pdf

${ }^{434}$ Ibid, 433.
} 
Therefore, even though it is difficult to argue against these clauses as effective mechanisms that can assist in attracting foreign development, the position of this research is that they are not constructed in such a way so as to achieve the real goal. These clauses ensure that tax incentives offered by the host country accrue to the foreign investor and not to the development of the host country.

The fear of developing countries that have not been addressed until now is the idea that tax sparing or matching credits can be counterproductive and they may encourage the foreign investor to engage in short-term investment projects. This statement can certainly be used as a strong argument in favour of the theory that such an increase in foreign investment does not necessarily aid in the development of developing or less developed countries. Even the commentaries on Articles $23 \mathrm{~A}$ and $23 \mathrm{~B}$ of the OECD MTC recognize that experience has shown that tax sparing is susceptible to taxpayer abuse. Taxpayer abuse is a type of abuse that is difficult to detect, and even when it is detected it is difficult for the state of residence to react quickly to remedy that tax abuse. ${ }^{435}$

Advocates of these clauses, as mechanisms that not only increase foreign investment but that also achieve an increase of development for developing or less developed countries, normally argue against deferral. The position of defending deferral as a better approach than tax sparing or matching credits, regarding their effect on development, has been traditionally criticized by stating that for some businesses, the fast repatriation of profits is a prerequisite and therefore deferral runs contrary to such a requirement. Both approaches are weak, since although the direct effect of deferral can be seen as re-investment and therefore, development, multinational tax structures end by repatriating profits to tax havens.

\footnotetext{
${ }^{435}$ OECD, Model Tax Convention on Income and Capital, 2010. Commentary on Articles 23 A and 23 B, paragraph 1.
} 


\subsubsection{BILATERAL INVESTMENT TREATIES AND DOUBLE TAX CONVENTIONS}

According to the United Nations Conference on Trade and Development (UNCTAD), ${ }^{436}$ Bilateral Investment Treaties (BITs) are: "Agreements between two countries for the reciprocal encouragement, promotion and protection of investments in each other's territories by companies based in either country". BITs are agreements between two sovereign states. From the point of view of the capital-importing country, the basic purpose BITs is to attract foreign investment, and, from the point of view of the capital-exporting country, the basic purpose of BITs is to guarantee protection to their investors. ${ }^{437}$

Regarding the effects of BITs on foreign investment, there is varied, but ultimately, consistent literature regarding the positive effect of BITs on foreign investment. Jeswald Salacuse and Nicholas Sullivan, in their work entitled "Do BIT's Really work? An Evaluation of Bilateral Investment Treaties and Their Grand Bargain", from 2005, analyse the topic by evaluating the impact of BITs in relation to their intended goals: (1) foreign investment protection; (2) investment and market liberalization; and (3) promotion of investment. They conclude that BITs do have a positive effect on foreign investment inflows and that the effect is greater when developing countries conclude these agreements with countries that are more economically developed.

Tim Buthe and Helen Milner achieved similar results in their work entitled "The Politics of Foreign Direct Investment into Developing Countries: Increasing FDI through International Trade Agreements?". Their study was conducted in 2008 and it analyses the topic by focusing on the mechanisms that are provided in BITs and how they make commitments to foreign investors about the treatment of their assets, thus reassuring investors and increasing investment. They conclude that these international commitments are more credible than domestic policy choices, because reneging on them is more costly. Statistical analyses for

\footnotetext{
${ }^{436}$ Definition of UNCTAD: "Body responsible for dealing with development issues, particularly international trade - the main driver of development". Available at: http://unctad.org/en/Pages/AboutUs.aspx.

${ }^{437}$ Sachs, Lisa E; and Sauvant, Karl P. BITs, DTTs, and FDI flows: An Overview in The Effect of Treaties on Foreign Direct Investment: Bilateral Investment Treaties, Double Taxation Treaties and Investment Flows, Oxford University Press, 2009. Available at: http://ccsi.columbia.edu/files/2014/01/Overview-SachsSauvantFinal.pdf
} 
122 developing countries from 1970 to 2000 support this argument. Thus, in their opinion, developing countries that belong to the World Trade Organization (WTO) and participate in more BITs experience greater foreign investment inflows than they otherwise would. By becoming party to international trade agreements, developing countries are able to attract more foreign investment and thus to increase economic growth.

With that said, the UNCTAD study on the topic was less conclusive than the studies above. In the 2009 work entitled "The Role of International Investment Agreements in Attracting Foreign Direct Investment to Developing Countries", as part of the UNCTAD Series on International Investment Policies for Development, UNCTAD concluded that BITs are part of the policy framework for foreign investment and are thus only one of many factors that impact on a company's decision on where to make an investment. As a consequence, BITs alone can never be a sufficient policy instrument to attract FDI. Other host country determinants, particularly economic determinants, play a much more powerful role in this regard.

Following the same line of reasoning, Mary Hallward-Driemeier in her work entitled " $D o$ Bilateral Investment Treaties Attract FDI? Only a bit... and they could bite" concluded that BITs had an insignificant effect on FDI flows in general. However, she found that they have positive effects in countries which possess an already stable business environment and reasonably strong domestic institutions. Thus, the negative effect pertains mainly to investments in riskier environments.

Despite some differences in the results of those studies, in all of the studies, but to different extents, the premise that BITs do have a positive effect on foreign investments inflows was confirmed.

As in DTCs between developing and developed countries, BITs between developing and developed countries completely depart from the logic of BITs that is relied upon between two developed countries. DTCs between two developed countries rely on the reciprocity principle, i.e. reciprocal reduction of withholding tax rates by source countries, as the best 
approach regarding the taxation of passive investment income whereas the BITs between two developed countries are based on the notion of reciprocity and mutual protection. ${ }^{438}$ When a BIT between two developed countries is in force, nationals from both countries expect to invest reciprocally in the territory of the other, and when a DTC between two developed countries is in force, residents from both countries expect to remove the obstacles that double taxation presents to the development of economic relations between the countries. ${ }^{439}$ In both types of agreements - DTCs and BITs - the above premises are not applicable to agreements that are concluded between developing and developed countries. Concluding and maintaining DTCs and BITs requires a bargain from which both parties must derive benefits. Thus, if those premises are not applicable - (1) nationals from both countries expect to invest reciprocally in the territory of the other and (2) both countries expect to remove the obstacles that double taxation presents to the development of economic relations between countries then why would developing countries enter into such agreements?

Regarding BITs, their stated purpose is to protect and promote foreign investment. Similarly, DTCs are intended to reduce the administrative complexities of foreign investments as well as to eliminate double taxation. In the author's understanding, in both DTCs and BITs the answer must be the same: the promotion of foreign investment. The theory that is supported by this research, namely that the increase of valuable foreign investment is the only way to counterbalance the limitation of developing countries' sovereignty when taxing passive investment income in a DTC between developing and developed countries, can be applied analogously to BITs. In the case of BITs, the limitation of sovereignty that justifies the goal of the promotion of foreign investment sought by developing countries is related to how BITs limit the ability of these countries to take the necessary legislative and administrative actions to advance and protect their national interests. ${ }^{440}$

The author's intention to combine DTCs and BITs or, more accurately, to include DTC aims within BITs, is not an isolated and novel idea. Eric Neumayer, in his work entitled "Do

\footnotetext{
${ }^{438}$ Salacuse, Jeswald W; and Sullivan, Nicholas P. Do Bits Really Work?: An Evaluation of Bilateral Investment Treaties and Their Grand Bargain. Harvard International Law Journal, Vol 46, 2005.

${ }^{439}$ OECD, Model Tax Convention on Income and Capital, 2017. Introduction.

${ }^{440}$ Ibid, 438.
} 
double taxation treaties increase foreign direct investment to developing countries?", described the joint goal of BITs and DTCs as follows:

"In their aim to increase FDI inflows, developing countries have resorted to bilateral treaties to signal their commitment to stable, correct and often favourable treatment offoreign investors. By signing DTCs, developing countries provide foreign investors with security and stability as regards the issue of taxation in addition to the relief from double taxation. By signing BITs, developing countries commit to grant certain relative standards such as national treatment (foreign investors may not be treated any worse than national investors, but may be treated better and, in fact, often are) and most-favoured nation treatment (privileges granted to one foreign investor must be granted to all foreign investors). They also agree to guarantee certain absolute standards of treatment such as fair and equitable treatment for foreign investors in accordance with international standards after the investment has taken place. BITs typically ban discriminatory treatment against foreign investors and include guarantees of compensation for expropriated".

In accordance with international standards, BITs also guarantee fair and equitable treatment for foreign investors after the investment has been made. They typically also proscribe discriminatory treatment against foreign investors and include guarantees of compensation. ${ }^{441}$

The first DTC was concluded in 1899 between Austria-Hungary and Prussia and the first BIT between Germany and Pakistan was only signed in 1959. This makes it difficult to justify the theory that DTCs are complementary agreements to BITs. However, what matters for the purposes of this research is that DTCs between developing and developed countries only started to be signed in the 1960 s as a consequence of the same historic reasons that justified the proliferation of BITs. After the end of World War II, the lack of agreements in force, the increase in international trade, and the end of colonialism were key factors that

${ }^{441}$ UNCTAD: Bilateral Investment Treaties in the Mid 1990s, 1998. 
determined the need for guidelines for the negotiation and conclusion of DTCs and BITs between developing and developed countries. Thus, considering the causes and the historic context of both types of agreements, the author is of the opinion that it is necessary to unveil the complementary role of DTCs and BITs by including the aims of BITs in DTCs between developing and developed countries, i.e. the UN MTC.

The rationale behind the proposal is the fact that, although the development of domestic legislation of developed countries has taken over the main role of DTCs, that is the elimination of double taxation, for developing countries there has always been an underlying and main aim when signing a DTC with a developed country, which is to increase foreign investment. Thus, although that aim is not explicitly recognized in the literature, the UN MTC - being a Model that aims to govern DTCs between developing and developed countries - must be able to achieve that goal.

In practice, DTCs and BITs are normally part of broader economic reform packages in developing countries. Although they are included in packages alongside free trade agreements or reforms in domestic legislation, it is clear that, at least regarding DTCs, their rules neither reduce the administrative complexities of foreign investments nor confront double taxation in a more efficient manner than that provided for in domestic legislation.

\subsubsection{LATEST DEVELOPMENTS}

The 2017 update to the OECD MTC is a consequence of the measures approved by the final BEPS Reports. ${ }^{442}$ On 11 July 2017, the OECD released the draft content. Working Party Nº 1 of the Committee on Fiscal Affairs constantly reviewed and updated the MTC to address new issues in relation to DTCs. The last update to the MTC came in 2014. The changes address the recommendations that were contained in the final report in Action 2 "Neutralising the Effects of Hybrid Mismatch Arrangements", Action 6 "Preventing the Granting of Treaty Benefits in Inappropriate Circumstances", Action 7 "Preventing the Artificial Avoidance of

${ }^{442}$ OECD BEPS Project: Final Reports, 2015. Available at: http://www.oecd.org/ctp/aggressive/beps-2015final-reports.htm 
Permanent Establishment Status", and Action 14 "Making Dispute Resolution Procedures More Effective".

On 7 June 2017, the "Multilateral Convention to Implement Tax Treaty Related Measures to Prevent Base Erosion and Profit Shifting" (MLI) was signed. ${ }^{443}$ That instrument, as well as the BEPS Project, demonstrated the OECD's lack of intention to change the criteria used in its MTC for the purposes of allocating taxing rights. The erosion of the tax base of developing countries will continue, and certainly not because of taxpayer abuse but as a direct consequence of the status quo of the UN regarding the way in which DTCs between developing and developed allocate taxing rights.

In the context of this research, it is worth mentioning the proposal stated in the final report of Action $6^{444}$ regarding dividend income taxation at source and the requirement to benefit from the reduced withholding tax. That proposal, regulated by Article 8 of the MLI, ${ }^{445}$ instead of allocating taxing rights to whomever it corresponds, insisted on reinforcing source countries' taxing rights by protecting them through a minimum holding period rule. The rule recommended by Action 6 to be included in subparagraph $a$ ) of Article 10(2) of the OECD MTC reads as follows:

“a) 5 per cent of the gross amount of dividends if the beneficial owner is a company (other than a partnership) which holds directly at least 25 per cent of the capital of the company paying the dividends throughout a 365 day period that includes the day of the payment of the dividends (for the purpose of computing that period, no account shall be taken of changes of ownership that would directly result from a corporate reorganisation, such a merger or divisive reorganisation, of the company that holds the shares or that pays the dividends".

\footnotetext{
${ }^{443}$ OECD BEPS Project: Multilateral Convention to Implement Tax Treaty Related Measures to Prevent BEPS, 2016. Available at: http://www.oecd.org/tax/treaties/multilateral-convention-to-implement-tax-treaty-relatedmeasures-to-prevent-beps.htm

${ }^{444}$ OECD BEPS Project: Final Report Action 6: Preventing the Granting of Treaty Benefits in Inappropriate Circumstances, 2015. Available at: http://www.oecd.org/tax/preventing-the-granting-of-treaty-benefits-ininappropriate-circumstances-action-6-2015-final-report-9789264241695-en.htm
} 
The MLI provision states that:

"Provisions of a Covered Tax Agreement that exempt dividends paid by a company which is a resident of a Contracting Jurisdiction from tax or that limit the rate at which such dividends may be taxed, provided that the beneficial owner or the recipient is a company which is a resident of the other Contracting Jurisdiction and which owns, holds or controls more than a certain amount of the capital, shares, stock, voting power, voting rights or similar ownership interests of the company paying the dividends, shall apply only if the ownership conditions described in those provisions are met throughout a 365 day period that includes the day of the payment of the dividends (for the purpose of computing that period, no account shall be taken of changes of ownership that would directly result from a corporate reorganisation, such as a merger or divisive reorganisation, of the company that holds the shares or that pays the dividends)".

The UN followed the OECD approach in this respect. As was stated in the report on proposed BEPS-related changes to the UN MTC that was issued by Carmel Peters, ${ }^{446}$ the Committee of Fiscal Affairs considered that in order to prevent abuse of the lower withholding rate for direct investment dividends, a 365-day holding period should be inserted into subparagraph (a) of Article 10 of the UN MTC. This 365-day holding requirement may be met either at the time of the payment of the dividend or after the dividend is paid. ${ }^{447}$ Furthermore, and by increasing the right of the source country to tax, it was agreed to increase the threshold for the reduced dividend withholding tax from $10 \%$ to $25 \% .{ }^{448}$ The proposed amendment to paragraph 2 of Article 10 of the UN MTC reads as follows:

\footnotetext{
${ }^{446}$ United Nations BEPS Project: Proposed BEPS-related Changes to the United Nations Model Double Taxation Convention between Developed and Developing Countries. Report by Coordinator Carmel Peters. Committee of Experts on International Cooperation in Tax Matters Twelfth Session, 2016. Available at: https://www.un.org/esa/ffd/wp-content/uploads/2016/10/12STM_CRP10_-beps.pdf

${ }^{447}$ Ibid, 447.

${ }^{448} \mathrm{Ibid}, 447$.
} 
"2. However, such dividends may also be taxed in the Contracting State of which the company paying the dividends is a resident and according to the laws of that State, but if the beneficial owner of the dividends is a resident of the other Contracting State, the tax so charged shall not exceed:

(a) _ per cent (the percentage is to be established through bilateral negotiations) of the gross amount of the dividends if the beneficial owner is a company (other than a partnership) which holds directly at least 25 per cent of the capital of the company paying the dividends throughout a 365 day period that includes the day of the payment of the dividend (for the purpose of computing that period, no account shall be taken of changes of ownership that would directly result from a corporate reorganisation, such as a merger or divisive reorganisation, of the company that holds the shares or that pays the dividend);

(b) _ per cent (the percentage is to be established through bilateral negotiations) of the gross amount of the dividends in all other cases.

The competent authorities of the Contracting States shall by mutual agreement settle the mode of application of these limitations.

This paragraph shall not affect the taxation of the company in respect of the profits out of which the dividends are paid".

The statement above confirms something that is already known, that is, that the BEPS project is a mere continuation of historic tax policies regarding the allocation of taxing rights in DTCs. The 2014 Report on "Developing a Multilateral Instrument to Modify Bilateral Tax Treaties", ${ }^{449}$ had the only purpose of eliminating potential opportunities for double nontaxation or less than single taxation, and for profit shifting by multinational enterprises, that could arise or even be facilitated by the current tax treaty system. ${ }^{450}$

\footnotetext{
${ }^{449}$ OECD BEPS Project: Final Report Action 15: Developing a Multilateral Instrument to Modify Bilateral Tax Treaties, 2015. Available at: https://read.oecd-ilibrary.org/taxation/developing-a-multilateral-instrument-tomodify-bilateral-tax-treaties-action-15-2015-final-report_9789264241688-en\#page1

${ }^{450}$ Silberztein, Caroline; and Tristram, Jean-Baptiste. OECD: Multilateral Instrument to Implement BEPS. IBFD, International transfer Pricing Journal, 2016. Available at:
} 
Finally, and probably one the most bespoke changes to the UN MTC by developing countries was the inclusion of a specific article dealing with the taxation of services. By extracting fees from technical services from Article 7 (combined with Article 5) and in some cases, from Article 12, the UN MTC managed to solve some practical problems in relation to the matter. Notwithstanding the fact that income from technical services is without doubt active income, it is unavoidable to refer to this relevant modification in the UN MTC. The inclusion of the new Article $12 \mathrm{~A}$ of the UN MTC is clearly related to the topics that have been criticized by this research, i.e., the effort of source countries on increasing their taxing rights instead of focusing on the elimination of barriers to facilitate cross-border trade and investment.

Before the introduction of Article 12A of the UN MTC, the rules governing the allocation of taxing rights gave limited scope to source countries to tax the income generated from those services in particular without a fixed base or permanent establishment in the country of source. ${ }^{451}$ The problem was partially solved, in practice, by some countries by endowing a broad interpretation of the expression "information concerning industrial, commercial or scientific experience" that is contained in Article 12 of the UN MTC and by including certain technical services within its scope.

What is expected in practice is to solve the problems that are generated by mixed contracts whereby an enterprise may provide services and the right to use property or know-how to a customer. Until now, and in accordance with paragraph 12 of the Commentary on Article 12 of the UN MTC (quoting paragraph 11.6 of the Commentary on Article 12 of the OECD MTC), the payments under the contract must be disaggregated into separate elements of payments for services and royalties, unless one element is merely ancillary and largely unimportant. ${ }^{452}$ The negotiation of the same rate for the taxation of fees for technical services

\footnotetext{
https://www.ibfd.org/sites/ibfd.org/files/content/pdf/International\%20OECD\%20\%200ECD\%20Multilateral\%20Instrument \%20to\%20Implement\%20BEPS.pdf

${ }^{451}$ United Nations BEPS Project: Taxation of Services. Report by Coordinator Liselott Kana. Committee of Experts on International Cooperation in Tax Matters Seventh Session, 2016. Available at: https://www.un.org/esa/ffd/wp-content/uploads/2016/10/12STM_CRP1_Services.pdf

${ }^{452}$ Ibid, 452.
} 
under the new Article 12A of the UN MTC and for royalties in Article 12, may help to alleviate difficulties in this regard, and it may be useful for developing countries that possess scarce administrative resources and allow them to reduce potential conflicts as a result of the application of the article. ${ }^{453}$

The ultimate development was the Principal Purpose Test, hereinafter: PPT, which is contained in the commentaries to paragraph 9 of Article 29 of the UN MTC. The PPT will be overridden by the proposals that are contained in this research. The aforementioned test requires the following two elements to be present for certain transactions or arrangements in order for them to constitute an abuse of the provisions of a DTC: (1) the main purpose for entering into these transactions or arrangements was to secure a more favourable tax position and (2) obtaining that more favourable treatment would be contrary to the object and purpose of the relevant provisions.

As known, this test is focused on the intention of the investor in a context where the objective and purpose of the provisions of the UN MTC are mainly restricted to the elimination of juridical double taxation. The drastic change regarding the objectives and purposes of the UN MTC proposed by this research requires a change in how anti-abuse rules in DTCs are constructed. As the real benefit of these proposals is the granting of only one tier of taxation in only one of the two contracting states for income that is derived from equity, debt financing and the licensing of goods, rights, or property (GRP) that generate royalty income, the focus of DTC anti-abuse rules should not be centred on the intention to obtain a tax benefit, but instead should focus on the conditions that are needed to grant those benefits at source. As will be proposed, the main condition for the treatment of equity, debt financing and the licensing of GRP that generate royalty income must be economically beneficial for developing countries. The emphasis is on the impact of the investments or transactions on the source/developing country. The aim is to make the UN MTC a cross-border agreement capable of aiding developing countries in their development journey. Thus, and due to the necessity of granting legal certainty to investors who reside in developed countries, the author defends that it is necessary to apply the substantive tests that are found in the proposals,

${ }^{453}$ Ibid, 452. 
instead of relying on a PPT, i.e. a substantive-economic test regarding the impact of all those investments or transactions, as well as an alternative temporary test in the case of equity, an arm's length test and an agreement nature test in the case of debts financing, and finally, an arm's length test in the case of GRP that generate royalty income.

Leaving the granting of benefits of a DTC between developing and developed countries to a PPT would be incompatible with the author's approach. The purpose of the PPT rule is to tackle DTC abuse by preventing taxpayers from claiming treaty benefits in abusive circumstances. The purpose of the author's proposal is to provide treaty benefits to beneficial investments or to those beneficial transactions that are made from developed to developing countries. What then can be considered as "DTC abuse" under the author's proposal? If the main objective is to help developing countries on their road to development by eliminating cross-border tax barriers, it seems whether the investor is entering into the transaction or arrangement in order to secure a more favourable tax position is not relevant. That is exactly what these proposals grant to investor residents in developed countries, i.e. if they invest in developing countries and those investments or transactions are considered by the source country to be economically beneficial to them, those investors will benefit from preferential tax treatments. Thus, it is absolutely right and compatible with the purposes of the new provisions to be proposed if foreign investors, lenders, and owners of GRP that generate royalty income enter into these investments or transactions in order to secure a more favourable tax position.

In the context of the author's proposals, and assuming that the conditions for benefitting from the DTC between the developing and the developed country are fulfilled, the source developing country's treatment of dividends, interest and royalty income will be similar, i.e. exemption at source plus taxation of business income that derives from those investments or transactions. Royalties and interest will be considered as legitimate tax expenses that are deductible as business expenses in the source developing country. By way of contrast, the tax treatment of dividends, interest and royalty income in the country of residence will differ. In the case of royalties and interest, both incomes will be fully taxed by that country. Dividends will be exempt not only at the corporate level but also at the personal income tax 
level. By so doing, passive investment income, i.e. income derived from equity, debt financing and the licensing of GRP that generate royalty income, will only be effectively taxed once.

Even though it could be argued, according to the same logic, that it is also not relevant for the source developing country whether the investor in the case of equity, the lender in case of debt financing and the owner of the GRPs that generate royalty income, effectively resides in the other contracting state; the author instead stresses the importance of respecting the principle that the benefits of the DTC will be only granted to the beneficial owner's residence in one of the two contracting states. This is essential in order to protect the tax base of the residence country. The country of residence will have exclusive taxing rights to tax royalties and interest under the scope of this proposal. However, it is undeniable the effort that residence countries will undertake by renouncing their right to tax all types of dividends not only at the corporate income tax level but also at the personal income tax level. Under that scenario, the risk of treaty shopping by residents of countries that do not have a DTC with the targeted developing countries is high.

According to this proposal, the tax treatment of foreign investor residents in developed countries with which the developing country has a DTC in force would be much more beneficial than the tax treatment of foreign investors that are resident in developed countries with which the developing country does not have a DTC in force. Although it seems to be an obvious result of the conclusion of a DTC, it is not. As an example, this would not be the case under the current treatment of income that is derived from passive investment income under the UN MTC. Hence, the concept of the beneficial owner will continue to remain of great importance for countries of residence. The sacrifice in revenue made by developed countries must not cover investments or transactions made by non-residents. Lastly, it is also essential to respect the sovereignty of developed countries that have decided not to conclude a DTC with a developing country under the proposed parameters. 
Treaty shopping refers to the use of a DTC, by persons who might not ordinarily come within its scope, in order to avoid paying taxes. ${ }^{454}$ The objective has always been linked to the reduction of source taxation regarding passive investment income or business income that is not connected to a permanent establishment. According to this proposal, that benefit will only be granted if the equity, debt financing and licensing of GRP that generate royalty income are economically beneficial to that developing country. Residence countries can deny the exemption of dividends if the beneficial owners do not effectively reside in their countries. However, the problem arises in the case of interest income that is derived from beneficial debt financing provided by lenders, and royalty income derived from beneficial GRP owned by licensors, when it does not fulfil the criteria of the country of residence to be considered as a resident of that country. In these two cases, those incomes will be exempted at source and taxed by the country of residency. Neither the host / source developing country nor the residence / developed country will have an interest in denying the benefits to these types of investments / transactions.

The beneficial owner concept is a common law trust concept that has no equivalent in civil law countries. ${ }^{455}$ Neither the UN MTC nor the OECD MTC actually define what is meant by the concept. There is only an attempt to describe its characteristics. In the commentaries to both MTCs, ${ }^{456} 457$ it is recognized that source countries, i.e. countries that waive the taxation of passive investment income, are not obliged to give up taxing rights merely because that income is immediately received by a resident of a country with which the source country has concluded a DTC. Moreover, both commentaries expressly state that the term beneficial owner is not used in the MTCs in a narrow technical sense and therefore it must be understood in the context and in the light of the object and purpose of the DTC, that is, amongst other things, the avoidance of double taxation and the prevention of fiscal evasion and

\footnotetext{
${ }^{454}$ Krishna, Vern. Treaty Shopping and the Concept of Beneficial Ownership in Double Tax Treaties. Canadian Current Tax, Vol 19, 2009.

${ }^{455} \mathrm{Ibid}, 455$.

${ }^{456}$ United Nations, Department of Economic and Social Affairs, Model Double Taxation Convention between Developed and Developing Countries, 2017. Article 12 paragraphs 1 and 2.

${ }^{457}$ OECD, Model Tax Convention on Income and Capital, 2017. Commentary on Article 12 paragraphs 1 and 2.
} 
avoidance. ${ }^{458} 459$ Thus, notwithstanding that the UN and the OECD have not advocated treaty shopping, they never assumed to express that principle in the models by defining and determining the scope of the term "beneficial owner".

The decision adopted in the Prevost case is very important in this regard. ${ }^{460}$ The issue was whether a Dutch holding B.V (Prevost Holding B.V.) was the beneficial owner of dividends that were paid for by the Canadian company Prévost Car. The shareholders of Prevost Holding B.V. were the Swedish company Volvo Bussar A.B and the British company Henlys Group PLC. The Canadian Minister of National Revenue issued assessments under Part XIII of the Canadian Income Tax Act on the basis that the beneficial owners of the dividends were the corporate shareholders of the Prevost Holding B.V., instead of Prevost Holding B.V. itself.

The court held that Prevost Holding B.V. was the beneficial owner of the dividends from Prévost. In the court's view the "beneficial owner" of dividends is:

"The person who receives the dividends for his or her own use and enjoyment and assumes the risk and control of the dividend he or she received. The person who is beneficial owner of the dividend is the person who enjoys and assumes all the attributes of ownership. In short the dividend is for the owner's own benefit and this person is not accountable to anyone for how he or she deals with the dividend income". 461

Thus, the beneficial owner is the person who can, in fact, ultimately benefit from the dividends.

\footnotetext{
${ }^{458}$ United Nations, Department of Economic and Social Affairs, Model Double Taxation Convention between Developed and Developing Countries, 2017. Article 12 paragraphs 1 and 2.

459 OECD, Model Tax Convention on Income and Capital, 2017. Commentary on Article 12 paragraphs 1 and 2.

${ }^{460}$ Baas, Nicolas. Prevost Car Inc. v. The Queen, Moodys Gartner Tax Law LLP, 2009. Available at: https://www.moodysgartner.com/prevost-car-inc-v-the-queen/

${ }^{461} \mathrm{Ibid}, 461$.
} 
The main argument of the court was that a holding company would not necessarily be treated as the beneficial owner of the income received by another company unless the company is a conduit with absolutely no discretion as to the use or application of that income. Therefore, and since in the case described the dividends received by Prevost Holding B.V. were from that company and it could do what it wanted with that income until the director's decision as to the distribution of dividends, the company was not regarded as a mere conduit company.

An interesting evolution of the principles governing the concept has arisen in Germany. On 4 April 2018 the German Ministry of Finance (MOF) issued an official guidance regarding the German anti-treaty shopping rule. The guidance was a response to the European Court of Justice decision in the joint cases of Deister Holding C-507/16 and Juhler Holding C-613/16. Although the decision concerns a former version of section 50d(3) of the German Income Tax Act which was applicable until 2011, significant conclusions were drawn for the current version of the law. ${ }^{462}$

According to the MOF guidance, holding companies engaged in mere asset managing activities can claim dividend withholding tax relief under the Parent-Subsidiary Directive. Until that guidance, withholding tax levied on dividends distributed by a German subsidiary to an intermediary parent company were not refunded by the German tax authorities since the governing law only allows treaty and parent subsidiary benefits for a foreign intermediary if the foreign intermediary derives income from performing its own economic activities, or if there are substantive economic reasons for interposing the entity mentioned above, i.e. the business purpose test; or the entity engages in business activity having sufficient resources, i.e. substance test.

Until this latest discussion, all anti-treaty shopping rules use a strict concept of beneficial owner for the purposes of given or denied treaty benefits. This new German approach has

\footnotetext{
${ }^{462}$ EY Global Tax Alert, German Federal Ministry of Finance reacts to CJEU decision regarding German anti-treaty shopping rule, 2018. Available at:

https://www.ey.com/Publication/vwLUAssets/German_Federal_Ministry_of_Finance_reacts_to_CJEU_decisi on_regarding_German_anti-treaty_shopping_rule/\$FILE/2018G_02073-

181Gbl_German\%20FMoF\%20reacts\%20to\%20CJEU\%20decision\%20re\%20German\%20antitreaty\%20shopping\%20rule.pdf
} 
incorporated the discussion of the concept of "Ultimately genuine self-business activities". According to the guidance, mere passive asset management activities, i.e. holding company activities, should qualify as genuine business activities provided that the company exercises its shareholder rights. ${ }^{463}$ The relief could be claimed even in cases where no management functions are exercised. Thus, the German MOF states that in the case of passive asset management activities, Germany will consider the holding company as the beneficial owner for treaty purposes even though that company does not employ management and other personnel at all times in its country of residence.

This proposal considers that the concept "beneficial owner" should be present in the UN MTC regarding dividend income in order to test if the benefits must be granted. In the case of interest and of royalties, where it is less likely there will be any interest from the two countries in tackling the transactions, the recommendation is to also include the concept in order to respect the sovereignty of the countries from where the investors are effectively residents or not to conclude a DTC with the targeted developing countries.

${ }^{463} \mathrm{Ibid}, 463$. 
PART IV. DIVIDENDS: TESTS, NEW PROPOSAL, DIVIDEND TAXATION and the UN MODEL

\subsection{PRELIMINARY CONSIDERATIONS OF FOREIGN DIRECT INVESTMENT AND FOREIGN PORTFOLIO INVESTMENT}

DTCs differentiate between FDI ${ }^{464}$ and FPI. ${ }^{465}$ The argument behind this tax policy is that when the foreign shareholder is a parent corporation that owns a significant portion of the stock of the dividend-paying subsidiary corporation, the combination of the corporation tax on the subsidiary and the dividend source withholding tax may exceed the tax payable by the parent corporation on the same amount of income from operations within the country of its residence. Thus, in order to avoid any obstacles to the international flow of capital, DTCs distinguish between FDI and FPI. Although it cannot be considered as discrimination since a full credit will be granted in any case regarding FPI, both types of dividends are in fact taxed differently.

${ }^{464}$ UNCTAD: Comprehensive Study of the Interrelationship between Foreign Direct Investment (FDI) and Foreign Portfolio Investment (FPI), 1998. Available at:

http://unctad.org/en/Docs/pogdsdfsbd5.pdf According to the document, FDI is "the category of international investment in which a resident entity in one country obtains a lasting interest in an enterprise resident in another country. A lasting interest implies the existence of a long-term relationship between the direct investor and the enterprise and a significant degree of influence by the investor on the management of the enterprise. The criteria used to distinguish direct investment from other types of investment is that 'a direct investment is established when a resident in one economy owns 10 percent or more of the ordinary shares or voting power, for an incorporated enterprise, or the equivalent, for an unincorporated enterprise'. All subsequent transactions between affiliated enterprises, both incorporated and unincorporated, are also classified as direct investment transactions. Direct investment is divided into equity capital, reinvested earnings, and other capital."

${ }^{465} \mathrm{Ibid}, 462$. According to the document, FPI "includes investments by a resident entity in one country in the equity and debt securities of an enterprise resident in another country which seek primarily capital gains and do not necessarily reflect a significant and lasting interest in the enterprise. The category includes investments in bonds, notes, money market instruments and financial derivatives other than those included under direct investment, or in other words, investments which are both below the ten per cent rule and do not involve affiliated enterprises. In addition to securities issued by enterprises, foreigners can also purchase sovereign bonds issued by governments. According to the IMF's 1996 Coordinated Portfolio Investment Survey Guide the essential characteristic of instruments classified as portfolio instruments is that they are traded or tradable." 
When re-thinking the taxation of dividend income within the context of the UN MTC, it is necessary to analyse if the ongoing principles governing the taxation of that income in the UN MTC are appropriate. Thus, under the line of research of this work, the analysis of taxation of FDI and FPI must be carried out by taking the impact of both types of equity investments in host/source/developing countries into consideration. There is consistent economic and financial literature that supports the theory that both FDI and FPI can promote sustainable growth in developing economies. FDI and FPI provide economic benefits and together they can enhance those benefits.

FDI is primarily motivated by the long-term realization of returns from a company in a foreign country. It involves the establishment of an entity - a subsidiary - by the parent company. The foreign investor can usually influence the management of the business and take part in the strategic decision-making process of the business. ${ }^{466} \mathrm{FPI}$, on the other hand, is essentially focused on the creation of short-term benefits in the host country. ${ }^{467}$

Kimberly Evans, in her work entitled "Foreign Portfolio and Direct Investment, Complementary, Differences, and Integration", ${ }^{468}$ a contribution to the discussion in the OECD Global Forum on International Investment held in Shanghai in December 2002, concluded that characterizing FPI as "bad" and FDI as "good" essentially oversimplifies a much more complex situation. Both bring risks and both require their own separate approaches to policy. If one takes the word "foreign" out of foreign portfolio or direct investment, most policymakers would acknowledge that domestic portfolio and direct investment are both necessary for promoting healthy economic growth and development. Thus, put "foreign" back in and one effectively increases the quantity and diversity of investments to an even greater effect. Both FPI and FDI can bring powerful benefits to the economy, and together the benefits are increased.

\footnotetext{
${ }^{466}$ Chaudhuri, Sarbajit and Mukhopadhyay, Ujjaini. Foreign Direct Investment in Developing Countries. A Theoretical Evaluation, India, Springer 2014. p. 301.

467 Ibid, 467.

468 OECD, Global Forum on International Investment. Attracting Foreign Direct Investment for Development, 2002. Available at: https://www.oecd.org/investment/investmentfordevelopment/2764407.pdf
} 
Masaya Sakuragawa and Yoshitsugu Watanabe, in their research entitled "Foreign Direct and Portfolio Investments in the World" 469 concluded that, by considering the importance of both types of investments, emerging economies need FDI or FPI depending on the development of their financial markets. ${ }^{470}$ Thus, they indicated that, as the financial market develops beyond a certain threshold, countries are able to attract FDI inflows. If financial market development exceeds a certain threshold, equity portfolio investment then begins to flow in. They suggest that financial development contributes to economic growth by attracting capital flows in different ways, according to the degree of development, and accordingly they advise that domestic financial market development be prudent in relation to lifting capital control and promoting the consolidation of the various financial infrastructures in order to attract FDI and spur economic growth. After the degree of financial market development exceeds a certain threshold, a country with a sophisticated domestic financial market development should lift capital control in a positive manner in order to attract FPI and therefore continue to bring about economic growth.

FPI increases liquidity ${ }^{471}$ and it also helps the efficiency of markets, resulting in a deeper and broader market. It also brings discipline, know-how into host markets ${ }^{472}$ and the promotion of the development of equity markets and it thus enables the shareholders' voices to be heard in corporate governance mechanisms. ${ }^{473} 474$ Thus, FPI is a determining factor in assessing the strength of domestic capital markets and it improves their functionality, which leads to a proper allocation of capital and resources and thus to a healthier economy. ${ }^{475}$

\footnotetext{
${ }^{469}$ Sakuragawa, Masaya; and Watanabe, Yoshitsugu. Foreign Direct Investment and Portfolio Investments in the World, Keio University, 2009. Available at: https://www1.gsec.keio.ac.jp/upload/freepage/file/S-1-10.pdf ${ }^{470}$ Reisen, Helmut; and Soto, Marcelo. Which Types of capital Inflows Foster Developing-Country Growth? International Finance, Vol 4, 2001.

${ }^{471}$ Levine, Ross; and Zervos, Sara. Stock Markets, Banks, and Economy Growth. The American Economic Review, Vol 88, 1998.

${ }^{472}$ Evans, Kimberly. Foreign Portfolio and Direct Investment. Complementary, Differences, and Integration. OECD, Global Forum on International Investment. Attracting Foreign Direct Investment for Development, Shanghai, 2002. Available at: http://www.oecd.org/investment/investmentfordevelopment/2764407.pdf.

${ }^{473}$ Feldman, Robert A.; and Kumar, Manmohan S. Emerging Equity Markets: Growth, Benefits, and Policy Concerns. The World Bank Research Observer, Vol 10, 1995.

${ }^{474}$ Ibid, 473.

${ }^{475} \mathrm{Ibid}, 473$.
} 
FDI helps to strengthen economic potential, ${ }^{476}$ e.g. by adding new and different economic activities and consequently by diversifying the economy. It also promotes competition by spurring other competitors to increase their own efficiency and productivity. ${ }^{477}$ Another direct effect is the development of human capital. Foreign investors bring their management skills and technology to their enterprises. ${ }^{478}$

The secretariat of the United Nations Conference on Trade and Development (UNCTAD) issued a report in 1999 entitled "Comprehensive Study of the Interrelationship between Foreign Direct Investment and Foreign Portfolio Investment", ${ }^{479}$ which acknowledged the positive effects of both types of investments in host economies. The UNCTAD stated that FDI and FPI, as components of capital flows, may contribute to financial growth. The Report stated that the contribution of FDI in the context of development is directly due to the fact that transnational corporations establish subsidiaries that can directly increase the level of investment in host countries and as a consequence, augment their productive capacity and employment. Although this is not always the case, the UNCTAD has also concluded that FDI brings ancillary services by transferring technology, management expertise and marketing skills. Regarding FPI, the Report concluded that it aids in the development process by providing liquidity in domestic capital markets. Increased corporate governance as well as increased transparency and disclosure will be required from companies with foreign investors and an increase of the amount of risk capital available for new enterprises.

The potential relevance of both types of investments for developing countries is undeniable. Thus, there should not be any differences regarding their tax treatment. For this research, FDI and FPI can be differentiated not only between them but also within them, as beneficial or non-beneficial foreign investments for host / developing countries. Consequently, and only according to that segmentation, this research proposes a different tax treatment in this respect.

476 OECD, Foreign Direct Investment for Development. Maximising Benefits, Minimising Costs. Overview, 2002. Available at: http://www.oecd.org/investment/investmentfordevelopment/1959815.pdf

477 Ibid, 473.

${ }^{478}$ Ibid, 473.

${ }^{479}$ UNCTAD: Comprehensive Study of the Interrelationship between Foreign Direct Investment (FDI) and Foreign Portfolio Investment (FPI), 1998. Available at: http://unctad.org/en/Docs/pogdsdfsbd5.pdf 
Besides what has been mentioned above, the justification already mentioned for the differentiation between FDI and FPI made by the UN MTC and by the OECD MTC, i.e. that the actual differentiation can be justified by arguing that the two tiers of taxation at source may exceed the tax payable by the parent corporation on the same amount of income from operations within the country of its residence, loses all of its substance under the rules that will be proposed in this research. Briefly stated, the proposal regarding the taxation of dividend income consists of, once certain conditions have been fulfilled, the elimination of withholding taxes at the host / source country for both types of equity investments, alongside the elimination of economic double taxation by exempting dividends from tax, not only at the corporate income tax level, when the shareholder that receives the dividends is a legal entity, but also at the personal income tax level of the individual and ultimate beneficial owner. The exemption will be granted not only for individuals who invest directly, but also for individuals' final shareholders of the legal entity that received the exempted dividends.

Thus, if a parent company faces a higher tax burden when receiving dividends from the host subsidiary due to the fact that the corporate income tax at the subsidiary level is higher than that of the country of its residence, it should not be problematic since it is evident that FDI that is only made because of low tax conditions is risky for developing countries. In other words, it should not be considered as a loss of beneficial foreign investment of the country that doesn't succeed because the corporate income tax of the source country is considered to be high. Notwithstanding the aforementioned remarks, it will always be a sovereign option of the developing country to limit the rate of corporate income tax to a worldwide accepted rate, in order for it to incentivize foreign investment.

Also, no double taxation arises, either juridical or economic, by granting only one tier of taxation at source - business profits / corporate income tax - for the taxation of dividend income in DTCs between developing and developed countries, and no taxation at the residence country level.

If there is a different tax treatment that aims to incentivize foreign equity investment in developing countries, it does not have to be done by treating FDI and FPI differently; it has 
to be done, according to this research, by differentiating between beneficial and nonbeneficial foreign investment.

\subsection{PRIMARY ECONOMIC ACTIVITY GENERATING DIVIDENDS}

The first task that must be undertaken before designing the proposal for dividend taxation in a DTC between developing and developed countries is to ascertain where the economic activity that generates this income is located. By doing this, this research aims to state the rights that will be renounced by developing and by developed countries when subscribing to a DTC that considers the parameters that are laid down in this proposal.

To determine where the economic activity that generates dividends takes place, it is necessary to look into the origin of dividends. The origin of the dividends is where the profits have been produced from which the dividends derive. ${ }^{480}$ As Eric Kemmeren stated, if the company carries on its enterprise in its state of residence, the state of origin and the state of residence of the company will coincide. ${ }^{481}$ In the analysis of the problem, this research will use the basic case of dividend income, i.e. the situation in which the foreign shareholder is an individual and the situation in which the foreign shareholder is a legal entity. In both cases, the ultimate individual beneficial owner and the shareholder reside in the other contracting state. Following the same line of reasoning, in both situations it is assumed that the country of residence of the payer company is the country in which the profits of that company have been produced. Further complexities can exist, as is the case when the ultimate individual beneficial owner resides in a third country or when the profits of the company have not been produced in the country in which the payer company is incorporated. Those cases will not be considered any further in this research since the aim of this research is to propose a new core principle regarding the taxation of dividend income in DTCs between developing and developed countries, and for that it is better to focus on that main rule. Those cases will be left for further research work on this topic.

\footnotetext{
${ }^{480}$ Kemmeren, Eric C.C.M. Principle of Origin in Tax Conventions: A Rethinking of Models, The Netherlands, Pijnenburg, 2001.

${ }^{481}$ Ibid, 481.
} 
Eric Kemmeren argues that the origin of the dividends is exclusively in the host / source / origin country. ${ }^{482}$ This research, which deviates from Kemmeren's conclusion in this regard, states that it is also possible to find an economic nexus or link between the dividends and the country where the shareholder (the individual or legal entity) resides.

Although it was already explained why this research will not treat FDI and FPI in DTCs between developing and developed countries in different ways, it is undeniable that both incomes can differ in relation to their origin. The analysis of the place where the economic activity that generates dividends takes place differs by analysing dividends according to that differentiation.

Dividends that derive from business investments - FDI - are understood as dividends that are derived from cross-border equity finance initiatives where the investor - an individual or a legal entity - maintains a certain degree of control over the company that is being equity financed. Dividends derived from capital investments - FPI - are understood as dividends derived from cross-border equity finance initiatives where the investor - an individual or a legal entity - has no degree of control over the company that is being equity financed.

For the purposes of this research, the factor of control or involvement is a key determinant for evaluating the degree of influence of the investor over the financed company, and consequently, for determining the link between the country from which the investor is performing its activity and the income generated as a result of that activity. In this line of reasoning, the investor's decision to participate, in an influential way, in the economic life of the host country consequently creates a strong link between the dividends and the country where the investor resides, making it difficult to define those dividends as purely passive income. It is important to clarify that the influence referred to does not mean influence over the ownership structure on the board's functions and strategic decision-making; it simply refers to the influence of the investor in the future of the company by deciding to invest in that company and, of course, by being allowed to appoint a substantial portion of the board

\footnotetext{
482 Ibid, 481.
} 
of that company. The resources to be invested and the decision to invest those resources in a controlled company are performed in the country where the investor resides. Thus, even though the country in which the profits of the dividend payer company have been produced - in this research it is assumed to be the host / source / origin country - corresponds to the country where the act of the payment of the dividends and the decision of the board of the host company to distribute the dividends is carried out, it is also possible to find, in this case, substantive activities related to the origin of the dividends in the home / residence country. In conclusion, regarding dividends derived from business investments - FDI - not only is there an economic link to the host / source country but also a link to the home / residence country. The influence of the investor in the process that leads to the generation of profits is an important activity and therefore it is regarded as a determining factor in this analysis.

This link is difficult to locate when it concerns dividends derived from capital investments FPI - especially where there is no substantial activity executed by the investor. It is possible to conclude that dividends derived from cross-border equity finance - where the investor, whether an individual or a company, does not maintain any degree of control over the financed company - are purely passive dividends. Although they are purely passive dividends, and thus according to the current international consensus they represent income that should be taxed by the country where the investor resides, the fact that there is no clear primary economic activity in that country which can influence the income-generating process makes the current rule an uncaused rule. If the economic activity which generates the income is not carried out in the country where the investor resides, then it has to be, in the cases analysed in this research, in the host country. This conclusion is consistent with Kemmeren's thesis - what is known as the 'origin theory'.

Although dividends are an exclusive and independent type of income, it is necessary to stress the inevitable link between dividends and business profits. Ignoring this link would lead us to lose the context when thinking about a fair distribution of benefits in a DTC between a developing and a developed country. The UN MTC has defined dividends as "income from shares, 'jouissance' shares or 'jouissance' rights, mining shares, founders' shares or other rights, not being debt claims, participating in profits, as well as income from other corporate 
rights which is subjected to the same taxation treatment as income from shares by the laws of the State of which the company making the distribution is a resident". The definition of dividends concerns the distributions of business profits by any corporate body or any entity that is treated as a corporate body ${ }^{483}$ for tax purposes.

Regarding the origin of the income, it is possible to identify differences between business profits and dividends. The activity that gives rise to business profits is, without doubt, located in the country where the business is operative, and the activity that gives rise to dividends can be correlated to the activity that generates business profits, or not as the case may be.

According to the logic of this research, dividends for which their origin exclusively belongs to the host / source country (FPI), the preliminary rights in relation to the taxation of those dividends should correspond to the host / source country. In this context, it is advisable to analyse this idea by taking the fact that business profits are already taxed by the host / source / developing country at the corporate level into consideration. In order to do so, an MTC between developed and developing countries must ensure that the income will not be taxed again, i.e. it should provide for the elimination of economic double taxation.

According to the same logic, dividends whose origin can be attributed to both contracting states (FDI), the preliminary rights to tax should correspond not only to the host / source country but also to the home / resident country. As in the case of dividends derived from FPI, it is advisable to analyse these rights within a more extensive context. Firstly, considering that business profits are already taxed by the host / source / developing country at the corporate level and, secondly, by considering that in practice most home / resident / developed countries, by applying a CIN approach, exempt dividends derived from FDI at the corporate level. The country where the legal entity that received the exempted dividends, and where their final beneficial owners - individual shareholders - reside, normally maintain taxation rights at the individual shareholder level.

\footnotetext{
${ }^{483}$ United Nations, Department of Economic and Social Affairs, Model Double Taxation Convention between Developed and Developing Countries, 2017. Article 3 paragraph 1 subparagraph b).
} 


\subsection{DEPARTURE FROM THE UN MODEL APPROACH}

The different treatment of FDI and FPI has been applied in different ways by the UN MTC, in the article that governs the taxation of dividends. Paragraph 2 of Article 10 of the UN MTC states that:

"2. However, such dividends may also be taxed in the Contracting State of which the company paying the dividends is a resident and according to the laws of that State, but if the beneficial owner of the dividends is a resident of the other Contracting State, the tax so charged shall not exceed:

(a) __ per cent (the percentage is to be established through bilateral negotiations) of the gross amount of the dividends if the beneficial owner is a company (other than a partnership) which holds directly at least 25 per cent of the capital of the company paying the dividends throughout a 365 day period that includes the day of the payment of the dividend (for the purpose of computing that period, no account shall be taken of changes of ownership that would directly result from a corporate reorganization, such a as a merger or divisive reorganization, of the company that holds the shares or that pays the dividends).

(b)___ per cent (the percentage is to be established through bilateral negotiations) of the gross amount of the dividends in all other cases.

The competent authorities of the Contracting States shall by mutual agreement settle the mode of application of these limitations.

This paragraph shall not affect the taxation of the company in respect of the profits out of which the dividends are paid".

This paragraph restricts the host / source taxation of dividend income to a percentage that is to be agreed in bilateral negotiations regarding FDI in letter a), and FPI in letter b). In line with the rationale underpinning this research, the UN MTC approach, as the OECD does, is considered to be strong with regard to the rights of the host / source country vis-a-vis FPI. 
While in the OECD MTC, the direct and portfolio investment rates are 5\% and 15\%, respectively, developed / developing country treaties rates have traditionally ranged between $5 \%$ and $15 \%$ for direct investment dividends and between $15 \%$ and $25 \%$ for portfolio dividends. $^{484}$

\subsection{RENUNCIATION OF PRELIMINARY RIGHTS}

As has been stated, most home / residence developed countries have made clear in their domestic legislation their view regarding the taxation of dividends derived from FDI. Notwithstanding the view of the UN MTC and of the OECD MTC (CEN), most developed countries apply the CIN theory. By applying the Participation Exemption Regime, those countries almost achieve tax neutrality.

The analysis of the evolution of developed countries' domestic legislation can help to understand developed countries' tax policy aims in this regard. The Netherlands, Luxembourg and Austria adopted the participation exemption in $1971,{ }^{485} 1968^{486}$ and $1972,{ }^{487}$ respectively, in order to fully avoid economic double taxation. ${ }^{488}$ The United Kingdom adopted an indirect credit system in 1950 and switched to the exemption method in 2009; ${ }^{489}$ Japan adopted an indirect credit system in 1962 and also switched to the exemption method in 2009; ${ }^{490}$ Germany adopted an indirect credit system in 1972 and switched to the exemption method in $2001 ;{ }^{491}$ and Australia adopted a dividend rebate system from 1963 until 1987 and then switched to an indirect credit system before moving to

${ }^{484}$ United Nations, Department of Economic and Social Affairs, Model Double Taxation Convention between Developed and Developing Countries, 2017. Paragraph 10 of the commentary on Article 10.

${ }^{485}$ Kofler, Georg. Indirect Credit versus Exemption: Double Taxation Relief for Intercompany Dividends. IBFD, Bulletin for International Taxation, Vol 66, $\mathrm{N}^{\circ} 2,2012$.

${ }^{486} \mathrm{Ibid}, 486$.

${ }^{487} \mathrm{Ibid}, 486$.

${ }^{488} \mathrm{Ibid}, 486$.

${ }^{489} \mathrm{Ibid}, 486$.

${ }^{490}$ Masui, Yoshihiro. Taxation of Foreign Subsidiaries: Japan's Tax Reform 2009/2010. IBFD, Bulletin for International Taxation, Vol 64, N 4, 2010.

${ }^{491}$ Ibid, 486. 
exemption in $1991 .^{492}$ Furthermore, of the 35 OECD Members, 27 apply a territorial tax system, i.e. exemption, and only eight apply a worldwide tax system, with a credit. The group of eight ${ }^{493}$ countries that apply a worldwide tax system includes some of the least developed OECD countries - Chile, Greece, Korea (Rep.), Mexico and Poland. ${ }^{494}$

The literature interprets the above tendency as being the result of the choice of residence countries between CIN and CEN neutrality policies. ${ }^{495}$ However, and in addition to the neutrality discussion, ${ }^{496}$ there is a repatriation policy lurking behind those shifts. It is an undeniable truth, recognized for example in Japan's tax reform of $2009 / 2010,{ }^{497}$ that the indirect foreign tax credit system, combined with relatively high tax rates in the investor residence country and relatively low tax rates in host jurisdictions, creates a distinct bias against the repatriation of foreign profits. ${ }^{498}$ In November 2007, the Tax Commission of the Japanese government issued a report named "Basic Idea for Fundamental Reform of Tax Systems" in which the underlying reasons regarding the shift in approach were unveiled, as follows:

"For instance, as for the foreign tax credit system, a well-balanced system should be developed, in accordance with the principle that corporations should be allowed no deduction in excess of the tax burden they owe to Japan, while giving due consideration to the business realities of Japan's corporate groups, such as increases in the proportion of overseas operations and in the retained earnings at overseas subsidiaries". 499

\footnotetext{
492 Ibid, 486.

${ }^{493}$ Chile, Greece, Ireland, Israel, Korea (Rep.), Mexico, Poland, and United States.

${ }^{494}$ Ibid, 486.

495 See: Holmes, Kevin. International Tax Policy and Double Tax Treaties: An Introduction to Principles and Application. IBFD, 2007; Schön, Wolfgan. Tax Competition in Europe. General Report. Max Planck Institute, Munich. IBFD, 2003; and Neil, Stephens. A Progressive Analysis of the Efficiencies of Capital Import Neutrality. Law and Policy in International Business, 1998.

${ }^{496}$ Desai, Mihir A.; and Hines, James R. Jr. Evaluating International Tax Reform, National Tax Journal, Vol 56, 2003.Available at: http://papers.ssrn.com/sol3/papers.cfm?abstract_id=425943

${ }^{497}$ Japanese Tax Commission. Basic Idea for Fundamental Reform of Tax System, November, 2007. Available at: http://www.mof.go.jp/english/tax_policy/tax_commission/e0711a.pdf.

498 Masui, Yoshihiro. Taxation of Foreign Subsidiaries: Japan's Tax Reform 2009/2010. IBFD, Bulletin for International Taxation, Vol 64, $\mathrm{N}^{\circ}$ 4, 2010.

${ }^{499}$ Ibid, 498.
} 
This is also confirmed by the recent discussion in the United States regarding the shift from the worldwide income taxation system to a territorial tax system. 500501 The President of the United States Advisory Panel on Federal Tax Reform issued a proposal to change the system of taxation in the United States in November 2005. ${ }^{502}$ Those who are in favour of this shift argue that a switch to a territorial tax system would increase the repatriation of foreign earnings by United States multinational companies, generate economic growth and jobs in the United States, enhance the international competitiveness of many United States companies, and increase corporate tax revenues. ${ }^{503}$ Those against the change argue that the barrier to bringing foreign income back to United States is not the worldwide income taxation but the deferral, that is, the fact that the tax is elective. ${ }^{504}$

Hence, in a scenario between a developing and a developed country, once the analysis of where the primary economic activity of dividends takes place has already taken place and it is clear which country (host / source or home / residence) has preliminary rights to tax according to the origin of the income, then it is possible to determine the dimension of the effective renunciations that each country will undertake if it subscribes to a DTC which adheres to the parameters that are proposed in this research. The principles must be the increase of foreign investment in the host / source / developing country granting neutral tax treatment, legal security, certainty for the international activities of taxpayers, alongside the positive repatriation of benefits policy for investors in their home / residence country.

${ }^{500}$ United States of America, Public Law 115-97 known as "Tax Cuts and Jobs Act 2017". New Code section 245 A.

${ }^{501}$ Kane, Mitchell. Considering 'Reconsidering the Taxation of Foreign Income'. Tax Law Review, Vol 62, 2009.

502 President's Advisory Panel on Federal Tax Reform. Simple, Fair \& Pro-Growth: Proposal to Fix America's Tax System, United States of America, 2005. Available at: https://www.treasury.gov/resource-center/taxpolicy/documents/report-fix-tax-system-2005.pdf. For an early critique of the Panel's proposal see Shaviro, Daniel. A Blueprint for Future Tax Reform?: Evaluating the Reform Panel's Report, Tax Analysts, 2005. Available at:

https://www.researchgate.net/publication/265669277_A_Blueprint_for_Future_Tax_Reform_Evaluating_Ref orm_Panel's_Report

${ }^{503}$ Drabkin, Erik; Serwin, Kenneth; and Tyson, Laura D. Implications of a Switch to a Territorial Tax System in the United States: A Critical Comparison to the Current System, BRG Berkeley Research Group, 2014. Available at: http://www.thinkbrg.com/media/publication/391_BRG_Implications\%20of\%20Territorial\%20Tax_Nov2013. pdf

${ }^{504}$ Fleming, J. Clifton Jr; and Peroni, Robert J. Exploring the Contours of a Proposed U.S. Exemption (Territorial) Tax System. Tax Notes, Vol 109, 2005. 
The proposal includes renouncing preliminary taxing rights over dividend income, not only by the developing country but also the developed country. The host / source country must refrain from taxing dividends at the second tier at source, i.e. withholding tax, and the home / resident country must grant the elimination of cross-border economic double taxation. As already stated, this will be done by exempting dividends from tax not only at the corporate income tax level when the shareholder receiving the dividends is a legal entity, but also at the personal income tax level of the ultimate individual beneficial owner. The exemption will be granted not only for individuals who invest directly, but also for individuals' final shareholders of the legal entity that received the exempted dividends.

The exemption system fully secures the elimination of cross-border economic double taxation, ${ }^{505}$ which is a benefit that is not addressed by the UN MTC and, according to the analysis conducted in this research, is an essential measure, and probably the only one, that has the potential to effectively eliminate barriers and to increase trade and investment between countries. By doing so, the UN MTC could achieve the creation of a real incentive to promote the increase of foreign investment in the host / developing country while granting neutral tax treatment, legal security, certainty and a beneficial repatriation of benefits policy for investments made by investors of home / resident / developed countries. In accordance with the position of the OECD Committee on Fiscal Affairs, and unlike the position of OECD Members, ${ }^{506}$ this research concludes the necessity of including measures in a DTC between developing and developed countries to confront the problem of economic double taxation. The elimination of cross-border economic double taxation will be the in the hands of the home / residence country. It will be not only for dividends derived from business investments - FDI - but also for dividends derived from capital investments - FPI. The exemption will

\footnotetext{
${ }^{505}$ OECD Glossary of Tax Terms. Available at: http://www.oecd.org/ctp/glossaryoftaxterms.htm

${ }^{506}$ OECD, Model Tax Convention on Income and Capital, 2017. Paragraph 51 of the commentary on Articles 23 A and 23 B: "The Committee on Fiscal Affairs has considered whether it would be appropriate to modify Article 23 of the Convention in order to settle this question. Although many States favoured the insertion of such a provision in the Model Convention this met with many difficulties, resulting from the diverse opinions of States and the variety of possible solutions. Some States, fearing tax evasion, preferred to maintain their freedom of action and to settle the question only in their domestic laws."
} 
not only be at the corporate level - as is usually the case for a participation exemption - but also at the individual personal tax level.

According to the analysis previously carried out in this study regarding the location of the economic activity that generates the income, the rules mentioned above mean that by subscribing to a DTC that includes that rule, countries will renounce the following: (1) the source / developing country will renounce preliminary taxation rights over dividends derived from FDI and from dividends derived from FPI; (2) the residence / developed country will only renounce preliminary taxation rights over FDI. However, and considering that nowadays most developed countries through the domestic participation exemption actually exempt dividends derived from FDI, when the exemption is at the corporate level (when the shareholder receiving the dividends derived from FDI is a legal entity), this should not radically alter the position of residence / developed countries compared to the position that they currently have according to the contemporary UN approach. The same can be said regarding the taxation of dividend income derived from FDI or from FPI when the shareholder is an individual. This proposal moves away from the actual credit system granted by the UN MTC to exemption. Both eliminate economic double taxation and therefore the same objectives can be achieved. The real difference imposed by these proposals for residence / developed countries is their obligation to grant an exemption at the individual tax level of the ultimate beneficial owner of the legal entity that receives the exempted dividends. This is, according to the logic of this research, the only real means to achieve neutrality and to ensure that the income will be taxed only once.

The idea of limiting these preliminary rights to tax in DTCs between developing and developed countries is to encourage investors from developed countries to invest in developing countries. Tax barriers for investors are not only present in the host / source country; the repatriation of the benefits and, therefore, taxation at home, is equivalent to the aforementioned tax event regarding the disincentives to investing in the developing country. Repatriation policies must be commensurate with the main objective of promoting effective foreign investment in the developing country, i.e. investment beneficial to the country's 
development process. The quality of the investments in the host economy, therefore, becomes an essential element in this regard.

Lastly, and with the aim of ensuring that this approach will achieve the attraction of foreign investment that effectively helps in the development process of the host / source / developing country, the proposed rules will allow the source / host country to tax at a secondary level (withholding tax over dividends) when the foreign investment is not from those that could, according to certain tests, be considered as investments that assist in the development process. If that is the case, the residence country could also elect to change the tax treatment at the recipient level by moving away from the exemption system granted by this proposal to the credit system at the first level of recipients (individual investor or corporate investor), and by eliminating the exemption benefit at the individual tax level of the ultimate beneficial owner of the legal entity that receives the exempted / taxed dividends. The above will be measured by the application, by the host / source country, of an economic substantive test, i.e. on the impact of the foreign equity in the economy of the host country, or by the application of a temporal test, i.e. the determination of the permanence of the equity in the host / source country.

In conclusion, the benefits granted to the foreign investor by this proposal will not be available for investments that are not able to effectively assist in the development process. If that is the case, the outcome is simply what is implemented today. That is to say, taxing rights will be shared, and juridical double taxation will be eliminated through the exemption or credit system (residence country option). Economic double taxation as a barrier to increased trade and investment between countries will remain in existence.

\subsection{ECONOMIC-SUBSTANTIVE TEST}

As it is impossible to analytically separate the concepts of dividend and business profits, it is also impossible to separate the equity of the host company from the underlying business activities of the host company. The UN MTC must include a test that is able to determine the 
real impact of the foreign investment - the equity provided by the foreign investor into the host company - in the economy of the host country.

The aim of this economic substantive test is to differentiate between beneficial and less or non-beneficial investments for countries that are in the process of development, i.e. productive and counterproductive foreign investments for developing countries. That test can only be properly designed by economists and naturally depends on the economic characteristics of each host / developing country. It is impossible to define a concept of beneficial or non-beneficial investments that is applicable to all developing countries' economies.

By way of example, although the UNCTAD 2011 World Investment Report showed a slump in FDI flows into South Africa in 2010 compared to 2009, the South African economy grew relatively faster in 2010 than it did in 2009. The real output in the economy increased by $2.8 \%$ in 2010 , by way of contrast to a decrease of $1.7 \%$ in $2009 .{ }^{507}$ As was concluded by Jonas Mosia in his publication entitled "When is Foreign Direct Investment Beneficial to a Country and When Is It Not? The Case of South Africa", it was important for South African policymakers to focus their energies on drafting and implementing policy measures that have the effect of promoting "industrialization".

Laura Alfaro, in her publication "Foreign Direct Investment and Growth: Does the Sector Matter?", 508 concluded that, although there may be a positive correlation between economic growth and FDI in the manufacturing sector, the same cannot be said about the primary and services sectors. Jonas Mosia exemplified this situation with reference to Walmart in South Africa, which concerned the discussion about the positive and negative aspects of FDI in the retail sector for developing countries. He stated that the advantages of FDI in the retail sector are said to be lower prices for the consumers; however, the reality is that such investments have devastating effects on the economy. Manufacturers are displaced due to massive imports

507 Mosia, Jonas. When is Foreign Direct Investment Beneficial to a Country and When Is It Not? The Case of South Africa, SAIIA Policy Briefing Vol 44, 2012. Available at: https://saiia.org.za/research/when-is-foreigndirect-investment-beneficial-to-a-country-and-when-is-it-not-the-case-of-south-africa/

${ }_{508}$ Alfaro, Laura. Foreign Direct Investment and Growth: Does Sector Matter?, Boston, Harvard Business School, 2003. Available at: http://www.people.hbs.edu/lalfaro/fdisectorial.pdf 
and big retailers, such as Walmart, and they have the effect of displacing small economic players through various predatory pricing strategies.

Hence, since it is impossible for the author to design a test that is suitable for all host / developing countries, the definition of beneficial and non-beneficial investments in the proposal provided by this research will be left aside in order to be decided by each country according to their respective characteristics and economies. The idea of this test - definition - is to promote foreign investment that can have positive effects on the source country economy and, consequently positively enables, either directly or indirectly, the development of the host country.

In order to achieve this, it will be essential to ascertain the underlying business activities of the host company in the host country in order to distinguish between foreign equity investment that is being used in the generation of productive activities within the host country borders and, therefore, assists the host / developing country's development.

This is not a new approach in the context of MTCs. Although it was stated with a different purpose, and regarding different income, the Mexican MTC contained an economic substantive test in the article governing the taxation of income from any industrial, commercial or agricultural business. Paragraph 2 of Article 4 of the Mexican MTC, in addition to the fixed place requirement for permanent establishments, permitted source country taxation when significant sales took place within the source country, despite the absence of a fixed place of business, ${ }^{509}$ as follows: "If an enterprise or an individual in one of the contracting States extends its or his activities to the other State, through isolated or occasional transactions, without possessing in that State a permanent establishment, the income derived from such activities shall be taxable only in the first State". Although the approach was unsuccessful, the author considers it important to take this relevant historical source into consideration.

\footnotetext{
509 Cockfield, Arthur J. Reforming the Permanent Establishment Principle through a Quantitative Economic Presence Test, Canadian Business Law Journal, Vol 38, 2003.
} 
By differentiating between beneficial and non-beneficial investments, the test will allow a DTC to determine for which investments the MTC will grant better repatriating conditions. Thus, if the foreign equity is considered by the host country to be a beneficial investment within the borders of the host / source country, the elimination of juridical and economic double taxation by the home / resident and the source / host countries will be done by taxing those dividends only once (as business profits at the source / host country). On the other hand, both countries will recover their preliminary taxing rights. The source / host country will recover these rights by being permitted to tax at the second level with a withholding tax, and the home / resident country will be able to shift away from the exemption system to the credit system at the first recipient level (individual or legal entity investor) and additionally, by eliminating the beneficial treatment of exempting income at the level of the final individual beneficial owner of the legal entity that received the dividends.

In the case of beneficial investments, the foreign investor will be allowed to compete in the host / source country under the same, or under even better, conditions than domestic investors. This will depend on the domestic tax treatment of dividend income by local investors. They will most likely face better tax conditions than those granted for dividend income that is derived from investments made within their own country. Developed countries will manage to broaden their own markets by including those of developing countries as part of their own markets, i.e. without tax barriers for trade and investments.

In the case of non-beneficial investments, foreign investors will face the treatment that they face today. They will not be allowed to compete in the host / source country under the same conditions as the domestic investors of source / host countries. The conditions will be those imposed in their country of residence. Final tax rates of the income generated by the investment abroad will be the rates of the individual taxation in their home / residence countries.

The incorporation of a test is designed to go one step further than that which DTCs usually do. The relevance of the impact of the investment in the host / source / developing country is crucial in determining which investments deserve to benefit from incentives. 


\subsection{TEMPORARY TEST}

One alternative to the economic substantive test could be the use of a temporary test to differentiate between beneficial and less or non-beneficial investments for host / developing countries. Although a substantive approach is more suitable than a formal approach, the complexities that a substantive test can bring to developing countries with low tax administration capacities renders this temporary approach a viable alternative.

A temporal test would focus on differentiating between those dividends earned as a consequence of short-term equity investments and those dividends earned as a consequence of long-term equity investments. This does not mean differentiating between FDI and FPI, because, as already stated, this research considers the positive effect that both types of investments can bring to the economies of developing countries. The challenge requires determining different temporary thresholds for each type of investment.

The fact that long-term equity investments tend to obviate volatile market periods, leaving the expectation of dividends to the underlying company growth, and that the expectations of investors of short-term investment in relation to dividends are associated with trading the stock to take advantage of short-term market volatility that produces quick profits, makes the author realize that, if it is not possible to carry out a substantive test, it is therefore necessary to evaluate the time-presence of the investments by avoiding discriminating against FPI per $s e$. Thus, and as an alternative to the economic substantive test, the author proposes that a minimum duration of time-presence for the investment in the host country for FDI and another a minimum time-presence in relation to the investment for FPI should be required.

The presence of a time factor in DTCs has been historically associated with the taxation of active income, and particularly with the concept of a permanent establishment. The role of this time factor in articles governing the taxation of active income is related to the role of DTCs in the allocation of taxation rights in some specific cases, namely construction of the 
permanent establishment, thus preventing source country taxation if a required fixed period of time has not passed.

In a comparable approach, but regarding dividends, this research proposes to use this element in order to guarantee effective tax incentives for beneficial equity investments in DTCs between developing and developed countries. Thus, if it is possible to determine the time threshold at which active income is considered to be more source country linked, the author believes that it is not a great challenge for economists to determine the time threshold that will guarantee the minimum average time that equity investments need to be present in order to be truly effective in the economy of the host / developing country. As in the economic substantive test, the author leaves the determination of the most effective threshold to economic specialists.

The differentiation between beneficial and non-beneficial investments will determine the taxing conditions. If the foreign equity is considered by the host country to fulfil the period of time required, it will be considered as a beneficial investment, and therefore the beneficial taxation rules that have already been described will be granted to the investor. If the opposite is true, and if foreign equity is not considered by the host country as fulfilling the period of time required, it will be considered as a non-beneficial investment, and therefore traditional taxing rules, as have already been described, will apply.

\subsection{PROPOSAL FOR DIVIDEND TAXATION AND THE ELIMINATION OF DOUBLE TAXATION}

This work has justified, throughout the whole research, the position regarding the inadequate UN MTC approach in relation to the taxation of dividends. The inefficient approach of restringing the role of DTCs in allocating taxing rights when domestic legislation already does so is aggravated by the outcome of granting more taxing rights to the home / residence country and therefore restricting host / source countries rights, an approach that is in desperate need of reform. 
Those who advocate improving the situation by increasing the source / host taxation of dividend income rely on what is referred to as the benefit theory, that is, by considering the fact that host / source countries facilitate investor access to the market and therefore deserve a portion of taxing rights. However, they forget that source countries have already taxed that income in the form of business profits without restrictions.

Furthermore, considering the fact that host / source taxation would be the rule where there is no DTC in force, the limitation of sovereignty regarding dividend taxation that host / developing countries face by concluding a DTC with a developed country must be counterbalanced by an increase in foreign investment that will effectively aid in the host country's development process.

Thus, it can be affirmed that it is necessary to reform the system of dividend taxation that is prescribed by the UN MTC. The fact that DTCs that follow the UN MTC approach have no effect on the increase of foreign investment from developed to less developed countries - the contrary has not yet been proven - reinforces this proposal. The UN MTC must include, amongst its aims, the elimination of tax barriers such as economic double taxation as an incentive for cross-border investment that can effectively help in generating development in the host / developing country.

This work proposes a new article regarding the taxation of dividend income for the UN MTC, respecting a general framework according to the following guidelines:

(1) in order to provide an incentive for the use of the UN MTC as the MTC to be followed in DTCs between developing and developed countries, the treatment of dividend income must be beneficial to all actors, namely the investor / residence country, the host / developing country, and the investor;

(2) both signatory countries must sacrifice taxing rights in order to achieve the benefits;

(3) the income must be economically taxed only once; 
(4) taxing rights regarding dividends should be allocated in a coherent manner, irrespective of whether they arise in a developing or in a developed country; and

(5) activities carried out by the host company in the host country and the permanence of the equity in the host country's economy are the elements that will be considered as those which can determine the real impact of the equity in the economy of the host country.

As a consequence, this work proposes a modification to Article 10 of the UN MTC so as to properly regulate the taxation of income from dividends in conventions between developed and developing countries. This would read as follows:

\section{Article 10}

\section{DIVIDENDS}

1. Dividends derived from beneficial investments and paid by a company which is a resident of a Contracting State, to a resident of the other Contracting State cannot be taxed either by the first state due to the fact that those dividends were already taxed in the form of business profits, or by that other Contracting State. That exemption will be granted not only at the corporate income tax level in that other state but also at the personal income tax level. The exemption at the personal income tax level will be granted not only for individual investors receiving foreign dividends income, but also for the individual's ultimate beneficial owners of the legal entities receiving foreign dividends income when that income is further distributed to them. The above under the condition that those individual's ultimate beneficial owners are also residents of that other Contracting State. When the ultimate beneficial owner (or owners) are resident of a third country, the exemption benefit could be extended to them i.e. the other Contracting State will exempt that dividend distribution to them if the country of residence of those beneficial owners exempt that income from tax once received by those beneficial owners. 
2. However, dividends derived by non-beneficial investments may taxed in both Contracting States, this is, in the Contracting State of which the company paying the dividends is a resident, and in the other Contracting State.

The competent authorities of the Contracting States shall by mutual agreement settle the mode of application of these limitations.

This paragraph shall not affect the taxation of the company in respect of the profits out of which the dividends are paid.

a. The term "dividends", as used in this Article, means income from shares, “jouissance” shares or “jouissance” rights, mining shares, founders' shares or other rights, not being debt claims, participating in profits, as well as income from other corporate rights which is subjected to the same taxation treatment as income from shares by the laws of the state of which the company making the distribution is a resident.

b. The provisions of paragraph 1 shall not apply if the beneficial owner of the dividends, being a resident of a Contracting State, carries on business in the other Contracting State of which the company paying the dividends is a resident, through a permanent establishment situated therein, or performs in that other state independent personal services from a fixed base situated therein, and the holding in respect of which the dividends are paid is effectively connected with such permanent establishment or fixed base. In such case the provisions of Article 7 or Article 14, as the case may be, shall apply.

c. The terms "beneficial" or "non- beneficial investments" used in this Article can be defined as follows: (a) Beneficial Investments: [the definition will be defined, according to their economic reality, by each developing country that subscribes to this Model]; (b) Non-beneficial Investments: [the definition will be defined, according to their economic reality, by each developing country that subscribes to 
this Model]. The definitions may be based on an economic-substantive test or on a temporary test.

\subsection{RATIONALE OF THE PROPOSAL}

The main objective of this proposal is to grant, through the UN MTC, more beneficial tax treatment to investors that are resident in developed countries by way of contrast to those that are normally granted to them by domestic legislation. The proposal is based on the assumption that developing countries will be willing to relinquish taxation rights over dividends if the outcome of that decision results in a positive increase of beneficial foreign investment, i.e. that helps in the development process of developing countries.

The current UN MTC approach requires developing countries to partially limit their rights without necessarily obtaining positive results in the sense of an increase in foreign investment. That outcome is also usually achieved by domestic legislation without requiring a limitation of taxing rights over dividend income by the host / developing country.

This proposal modifies one of the traditional principles of MTCs. The allocation of taxing rights is no longer the direct result of the analysis of the primary economic activity. The primary economic activity analysis serves as a tool for developing countries to know what they have and what they will lose by signing a DTC that is based on this new UN MTC approach.

Regarding dividends, the result of the primary economic activity analysis was that, notwithstanding the strong logic underpinning the position that the origin of the dividends is always in the host / source country because that is the country where the profits of the payer company have been produced, it is also possible to find substantive activities that are related to the origin of dividends in the home / residence country. 
Instead of sharing taxing rights, this proposal calls for a limitation of those preliminary taxing rights by both signatory countries, with the aim of achieving the following benefits for all actors:

(1) an increase in beneficial foreign investment for the host/source/developing country; and

(2) legal security, certainty, beneficial repatriation of benefit conditions and equal conditions for foreign investors, when competing in the host / source / developing country, for home / resident investors and the home / residence country.

Host / source domestic legislation usually eliminates economic double taxation over domestic dividends regarding corporate shareholders that hold a relevant portion of the equity of the host company. However, for portfolio investors, and for all individual investors, irrespective of their participation, economic double taxation is not usually eliminated.

This proposal achieves elimination of:

(1) host country domestic economic double taxation over cross-border dividends regarding corporate or individual shareholders without prejudice to either the portion of participation in the equity of the host company or the characteristics of the investment. This outcome is the result of this research's view in the sense that, regarding incomes derived from cross-border transactions, if the source country has the right to tax, then that right to tax should be exercised only once. The risk of triple taxation by taxing twice at source is high; and

(2) cross-border economic double taxation over dividends regarding corporate shareholders and individuals if they arise from beneficial investments in the host / source country. 
Thus, this proposal expects the UN MTC to achieve its stated aims by limiting the preliminary rights to tax according to the primary economic activity analysis, thus ensuring the elimination of juridical and economic double taxation, avoiding tax discrimination between domestic and foreign investors, improving the tax treatment of cross-border dividends compared to the current UN MTC approach, and encouraging the investment of purely passive and controlled investments in the host / source / developing country. 


\section{PART V. INTEREST: TESTS, NEW PROPOSAL, INTEREST TAXATION and the UN MODEL}

\subsection{PRELIMINARY CONSIDERATIONS: DEDUCTIBLE EXPENSE FOR THE BORROWER, INCOME TAXED TWICE IN THE HANDS OF THE LENDER, NON-ECONOMIC DOUBLE TAXATION}

The historical tax treatment of domestic and cross-border interest has been to consider it as a tax-deductible expense for the borrower and income that is to be taxed in the hands of the lender. ${ }^{510}$ The underlying principle is that if a company pays for the use of a resource that does not belong to it, and it uses it for the purposes of its business, then the remuneration paid for the use of that resource is regarded as a tax deductible expense. ${ }^{511}$ On the contrary, the remuneration that a company pays to its shareholders on its own capital - dividends - is not considered to be a tax deductible expense. The underlying concept of this principle is that, by definition, a company's equity is part of the company's own resources and accordingly the dividends paid to shareholders are not comparable to the remuneration that is paid for other factors of production. ${ }^{512}$

Action 4 of the BEPS Project, ${ }^{513}$ at least for multinational groups, has changed this historical approach. The proposal considers the "interest stripping rules" 514 as the new way of determining the amount of interest that is deductible at source. As was stated by the OECD: "the recommended approach ensures that an entity's net interest deductions are directly

510 OECD BEPS Project: Public Discussion Draft BEPS Action 4, Interest deductions and other financial payments. December 2014 - February 2015. Available at: https://www.oecd.org/ctp/aggressive/discussiondraft-action-4-interest-deductions.pdf

${ }^{511}$ Finnerty, Chris J; and Merks, Paulus. Fundamentals of International Tax Planning. IBFD, 2007. p.107.

${ }^{512} \mathrm{Ibid}, 512$.

${ }^{513}$ OECD BEPS Project: Final Report Action 4: Limiting Base Erosion Involving Interest Deductions and Other Financial Payments, 2015. Available at: http://www.oecd.org/tax/limiting-base-erosion-involving-interestdeductions-and-other-financial-payments-action-4-2015-final-report-9789264241176-en.htm

${ }^{514}$ OECD Glossary of Tax Terms. Earning Stripping Rules: Anti avoidance rules applied to excessive extraction of corporate profits by way of tax-deductible payments (typically interest) generally to related third parties who may be tax exempt with respect to the interest or subject to a lower rate of tax. Unlike thin capitalization measures, which compare debt with equity, these rules may, in addition, compare taxable income before interest with income after interest and deny a deduction to the extent the latter falls short of a certain percentage, e.g. $50 \%$, of the former. However, since they only apply to companies with a particular (excessive) debt to equity ratio they may be seen as supplementary to thin capitalization rules. 
linked to its level of economic activity, based on taxable earnings before deducting net interest expense, depreciation and amortisation (EBITDA)". By doing so, the interest, known as the amount paid by a company for the use of a resource that does not belong to it and which it uses for the purposes of its business, will no longer be considered a fully granted tax deductible expense. The BEPS proposal not only refers to interest that is derived from related debt but also to non-related debt.

Since, in the context of cross-border loan agreements, the tax deduction for the borrower will not be offset against domestic taxation because the foreign lender paid taxes in his residence country, the source / borrower country normally adds a first tier of taxation for interest by withholding tax on the foreign lender. Taxation at source through a withholding tax is still considered by some authors as a means of avoiding the erosion of the source country tax base. ${ }^{515}$ In order to avoid the juridical double taxation that arises for the lender, considering the taxation at the source / borrower country (withholding tax) plus taxation in its residence country, the lender's country of residence normally grants a credit for the withholding tax that is paid at source.

The analysis of cross-border interest taxation has always been analysed in a comparative manner and the tax treatment of cross-border equity investments are typically assessed according to the achievement (or not) of neutrality. This traditional analysis proceeds from the assumption that the tax deductibility of interest payments present under most corporate income tax systems, when compared to the non-deductibility of equity, can create a distortion in the financing decision of companies. ${ }^{516}$ For this research, to consider that difference as a potentially distorting element is not therefore correct. Dividends and interest are different types of income per se, since they derive from different types of financing instruments, ${ }^{517}$

\footnotetext{
515 Arnold, Brian; and Barnes, Peter. Protecting the Tax Base of Developing Countries against Base-eroding Payments: Interest and Other Financing Expenses. United Nations, 2017. p. 104.

516 See: Fatica, Serena; Hemmelgarn, Thomas; and Nicodème, Gaëtan. The Debt-Equity Tax Bias: consequences and solutions, Taxation Papers, Working paper No 33, European Commission, 2012; Huizinga, Harry; Laeven, Luc; and Nicodème, Gaëtan. Capital Structure and International Debt Shifting, Journal of Financial Economics, Vol 88, 2007; and de Mooij, Ruud A. Tax Biases to Debt Finance: Assessing the Problem, Finding Solutions, IMF Staff Discussion Note, 2011.

517 Piltz, Detlev J. General Report in International Aspects of Thin Capitalization, Cahiers de droit fiscal international, Vol 81b, International Fiscal Association, 1996.
} 
518 i.e. equity and debt, ${ }^{519} 520$ which means that both have different legal, economic and financial repercussions for the financed company.

Equity financing is a means of company financing that is usually engendered through the issuance of shares to investors. Equity financing does not entail an assurance that the investment will bring a return; conversely, there are no limitations to the possible return. The investor (as an owner of the company) bears the risk of the business. Amongst several other characteristics, it is possible to also mention: (1) return linked to profits; (2) non-stated (long or indefinite) term for repayment / return; and (3) poor credit quality (i.e. high subordination in the payment chain).

Debt financing means that the company is financed by a loan. It typically involves raising money by issuing instruments such as notes and bonds to investors, who are then entitled to receive the principal of the amount that was lent as well as any accrued interest. The pricing of the interest is usually composed of: (1) return on the risk of default, plus (2) return on the opportunity cost, plus (3) compensation on inflation, plus (4) customary margin (spread). After a specified period of time, there may be the possibility to raise judicial proceedings or to force bankruptcy if no repayment is carried out. The OECD discussion draft on financial transactions $^{521}$ related with the implementation of BEPS Actions $8-10$ has included in the discussion of pricing of financial transactions between associate parties elements such as contractual terms, functional analysis, characteristics of financial products or services, economic circumstances, and business strategies. Amongst several other characteristics, it is

\footnotetext{
518 Brealey, Richard; Myers, Stewart; and Allen, Franklin. Principles of Corporate Finance, $11^{\text {th }}$ ed., United States, McGraw-Hill/Irwin, 2013. p. 385; and Tirole, Jean. The Theory of Corporate Finance, United Kingdom, Princeton University Press, 2006. p. 75.

519 Ernst, Markus. Toward a Level Playing Field for Thin Capitalization: German and US Approaches, Tax Notes International, Vol 43, 2006. p. 657. Definitions: Equity: “An unlimited claim to the residual benefits of ownership and an equally unlimited subjection of the burdens thereof."; Debt: "An unqualified obligation to pay a sum certain at a reasonably close fixed maturity date along with a fixed percentage in interest payable regardless of the debtor's income or the lack thereof".

${ }^{520}$ Schön, Wolfgan; Beuchert, Tobias A; Roesener, Astrid; Gerten, Andreas; Haag, Maximilian, Heidenbauer, Sabine; Hohmann, Carsten; Kornack, Daniel; Lagdali, Nadia; Mueller, Lukas; Osterloh-Konrad, Christine; Pohlhausen, Carlo; Redeker, Philipp; and Röder, Erik. Debt and Equity: What's the Difference? A Comparative View, Max Planck Institute for Intellectual Property, Competition \& Tax Law, Research Paper No. 09-09, 2009.

${ }^{521}$ OECD BEPS Project: Public Discussion Draft Actions 8-10, 2018. Available at: https://www.oecd.org/tax/transfer-pricing/BEPS-actions-8-10-transfer-pricing-financial-transactionsdiscussion-draft-2018.pdf
} 
also possible to mention: (1) return that is not linked to profits; (2) market term for repayment / return (arm's length); and (3) good credit quality (low level of subordination).

Regarding the taxation of cross-border interest, probably the most distinguishing feature of the outcome, after combining the legislation of the lender's country and that of the borrower's country, is that unlike dividends, interest payments do not suffer economic double taxation; interest payments are not taxed in the hands of both, the borrower and the lender. ${ }^{522}$ The borrower deducts the interest payments in its country of residence as expenses; the borrower's country taxes the interest income of the non-resident lender on a gross basis with a withholding tax and the lender's country taxes the interest income of the lender on a net basis, i.e. worldwide income taxation. As a consequence, only juridical double taxation occurs in this scenario.

As a part of a loan agreement, it is common to see that signatories agree that the payment and economic cost of the tax on interest at source is assumed by the payer. This does not alter the situation outlined above. The fact that the borrower pays the tax does not lead to, however, the generation of economic double taxation. If it is the case that the borrower undertakes to bear the tax chargeable at source, this is as though the borrower had agreed to pay additional interest to its lender that corresponds with the amount of such a tax. ${ }^{523}$ The most complex issue in relation to cross-border debt financing for developing countries is the increase in costs when interest rates are grossed up in loan agreements. This is the main reason why withholding taxes are probably the highest barrier to international debt capital financing insofar as it increases the private cost of international borrowing. ${ }^{524}$ The latest work that was carried out by Bryan Arnold and Peter Barnes ${ }^{525}$ recognizes that the result of the grossing up of interest payments by residents to non-residents lenders is that withholding tax is effectively

\footnotetext{
${ }^{522}$ See: Vogel, Klaus. Klaus Vogel on Double Taxation Conventions, $3^{\text {rd }}$ ed., 1997. p. 711; and Van de Vijver, Anne. The New US-Belgium Double Tax Treaty: A Belgian and EU Perspective, Belgium, Larcier, 2009.

${ }^{523}$ Vogel, Klaus. Klaus Vogel on Double Taxation Conventions, $3^{\text {rd }}$ ed., 1997. p. 712.

${ }^{524}$ Huizinga, Harry. International Interest Withholding Taxation: Prospects for a Common European Policy, International Tax and Public Finance, Vol 1, 1994.

${ }^{525}$ Arnold, Brian; and Barnes, Peter. Protecting the Tax Base of Developing Countries against Base-eroding Payments: Interest and Other Financing Expenses. United Nations, 2017. p. 47.
} 
borne by residents and thereby this increases the cost of borrowing by residents from nonresidents.

In regard to economic double taxation, the outcome of a limitation on the deductibility of interest at source, e.g. thin capitalization rules, ${ }^{526}$ interest stripping rules, ${ }^{527}$ or earnings stripping rules ${ }^{528}$ is probably the closest situation to it. Notwithstanding the fact that the application of those rules is similar to a situation of economic double taxation, strictly speaking, it is not. It leads to a broadening of the tax base at source, but this does not mean that the same income would be taxed twice by comparable taxes by two different jurisdictions. The author's opinion on this matter is that interest income will never suffer economic double taxation. The arguments to sustain this opinion is that in the case of the limitation on the deductibility of interest at source, the base out of which the interest might not be deductible is not the base out of which the payments are made. That is to say that interest payments do not depend on the profits of the financed company, but rather they depend on the stipulations included in the loan agreement. By way of an example, if there is no tax base out of which the interest payments can be deducted, the interest will still be paid out to the lender and it will be taxed accordingly by the lender's country. It is impossible to ascertain that the effect of a limitation on the deductibility of interest is that the 'same income' will be taxed twice. Notwithstanding the foregoing, i.e. that limitations on the deductibility of interest at source does not create economic double taxation, it is undeniable that those kinds of measures can have negative effects in the context of cross-border financing from

\footnotetext{
${ }^{526}$ Michielse, Geerten M.M. Treaty Aspects of Thin Capitalization, IBFD, Bulletin 57, No. 11, 1997. "Excessive debt funding from abroad is viewed by some countries as leading to an unacceptable erosion of their tax revenue base i.e. deductibility of interest against the non-deductibility of equity. Generally, under such rules, the interest on the amount of debt paid to a related party which exceeds the permitted level is non-deductible. The nondeductibility is the result of the application of the 'arm's length principle' or a 'fixed debt to equity' ratio". ${ }^{527}$ Ibid, 527: "To a further extent than thin capitalization rules i.e. by also applying it to unrelated parties; interest stripping rules aim to prevent tax base erosion provoked by excessive debt financing. In addition to the debt-equity analysis normally required by thin capitalization rules, this kind of anti-abuse rule addresses the difference between the taxable income before the payment of the interest and the taxable income after the payment of the income, rather than at a specific debt to equity ratio or the arm 's length amount."

528 Harris, Peter; and Oliver, David. International Commercial Tax, $1^{\text {st }}$ ed., United Kingdom, Cambridge University Press, 2010. "It is similar but not entirely identical to the concept of interest stripping. It also aims to prevent tax base erosion provoked by excessive debt financing. However, the non-deductibility of the interest payment is the result of the application of a debt to equity ratio plus the analysis of the percentage that the interest to be deducted corresponds to the company's adjusted income. This only applies to payments between related parties."
} 
developed to developing countries. If those rules are not accompanied with a limitation of taxation of those interests in the residence country (those not allowed to be deducted), they could constitute a disincentive for foreign debt financing.

For the purposes of this research, the main problem is not the differences in the tax treatment of debt and equity capital, but rather the loopholes that any different treatment could create, and therefore, the potential for abuse. ${ }^{529}$ There is no necessity to equate treatments, it is however necessary to sanction abuse. The fiscal losses and inequities that are created by these loopholes are particularly problematic in the case of international borrowing between related parties as they offer an easy substitution at no cost for equity investments. ${ }^{530}$ In particular, it is extremely harmful for countries to set aside hybrid instruments, i.e. payments that are deductible at source as debt capital and not taxed at residence as equity capital. ${ }^{531}$ The EU has worked to impose sanctions on the above. In 2014 and 2015 the European Council adopted two amendments to the Parent-Subsidiary Directive ${ }^{532}$ on the common system of taxation applicable in the case of parent companies and subsidiaries of different Member States. The 2014 amendment stated that the Member State of the parent company will be allowed to not tax profit distributions from the subsidiary only to the extent that such distributions cannot be regarded as tax deductible expenses for the subsidiary, the "antihybrid rule". 533 Subsequently, the 2015 amendment incorporated a binding general antiabuse rule.

\footnotetext{
${ }^{529}$ OECD BEPS Project: Final Report Action 4: Limiting Base Erosion Involving Interest Deductions and Other Financial Payments, 2015. Available at: http://www.oecd.org/tax/limiting-base-erosion-involving-interestdeductions-and-other-financial-payments-action-4-2015-final-report-9789264241176-en.htm

${ }^{530}$ Benshalom, Ilan. The Quest to Tax Interest Income: Stages in the Development of International Taxation, Virginia Tax Review, Vol 27, 2008.

${ }^{531}$ OECD BEPS Project: Final Report Action 2: Neutralizing the Effects of Hybrid Mismatch Arrangements, 2015. Available at: https://www.oecd.org/ctp/neutralising-the-effects-of-hybrid-mismatch-arrangementsaction-2-2015-final-report-9789264241138-en.htm

${ }^{532}$ Council Directive (EU) 2014/86, of 8 July 2014, amending Directive 2011/96/EU on the common system of taxation applicable in the case of parent companies and subsidiaries of different Member States. Available at: https://eur-lex.europa.eu/legal-content/EN/TXT/?uri=celex\%3A32014L0086; and Council Directive (EU) 2015/121, of 27 January 2015, amending Directive 2011/96/EU on the common system of taxation applicable in the case of parent companies and subsidiaries of different Member States. Available at: https://eurlex.europa.eu/legal-content/EN/TXT/?uri=CELEX\%3A32015L0121

${ }^{533}$ Council Directive (EU) 2014/86, of 8 July 2014, amending Directive 2011/96/EU on the common system of taxation applicable in the case of parent companies and subsidiaries of different Member States. Available at: https://eur-lex.europa.eu/legal-content/EN/TXT/?uri=celex\%3A32014L0086
} 
The risk of equating the treatments, at least for developing countries, is the loss of the opportunity to grant a convenient tax treatment to beneficial debt. Furthermore, what is worse is a sanctioning of interest that is derived from beneficial debt by not allowing any deduction to be granted. This, as was already announced, will start changing after the implementation of the BEPS proposal. Domestic legislation has developed rules such as thin capitalization rules, interest stripping rules or earnings stripping rules, with the aim of avoiding the harmful effects that the different cross-border tax treatments of both incomes could create. The risk of a tendency to equate the treatment of both incomes is substantial. The UN MTC and the OECD MTC rules regarding the cross-border taxation of passive investment income still maintain the position that dividends should be economically taxed twice and only once in relation to interest.

The BEPS Report puts the issue of interest squarely into focus. In addition to the harmful effects of economic double non-taxation as a result of recourse to hybrid instruments, BEPS is also expected to attack base erosion via the limitation of interest deductions and other financial payments.

Notwithstanding the relevance of the work carried out by BEPS on the matter, it is necessary to contextualize that work according to the parameters laid down in this research. The BEPS Project never questioned the actual parameters in relation to the taxation of debt versus equity in DTCs between developing and developed countries, namely that dividends are economically taxed twice and interest only once. If we consider the proposal that was laid down in this research in relation to dividend income, the outcome is that income derived from debts, and also income derived from equity, will be economically taxed only once. However, and by maintaining the essential differences between both, even in a scenario in which equity and debt are both economically taxed only once, interest will still be a deductible expense at source. The deductibility of interest at source is of the essence of that financing resource and it must be considered as a right that has been granted by source countries - in the context of this research: developing countries - that enables them to make it less costly for local borrowers to obtain debt capital from foreign investor residents located in developed countries. Restricting the deduction of interest due to the absence of taxing rights of source / 
developing countries regarding cross-border interest income can put cross-border debt capital financing in a disadvantageous position when it is compared to local debt capital financing. ${ }^{534}$

The scenario expected by this research for the treatment of debt and equity in DTCs between developing and developed countries is similar to that which now exists within the EU. The elimination of withholding taxes at source for dividends and interest (only for dividends derived from FDI in the case of EU, and for all dividends in the case of this research), exemption or credit at the residence country in the case of dividends and taxation at the residence country in the case of interest. The BEPS proposals on this matter are not included in the MLI, but they are currently being considered by the EU Member States for the purposes of their domestic laws. ${ }^{535}$ The same could take place in relation to developing countries in a context that is similar to that which is expected by this research. Under the logic of this research, developing countries should consider the use of limitations on interest deductions as a valuable tool for dealing with abusive situations. However, it should not be construed as a mechanism to recover taxing rights that have been renounced under a DTC that has been signed between them and a developed country.

Related debt creates a scenario for potential fiscal losses and inequities by offering an easy substitution for equity investments at no cost. The potential problem arises when a related party provides excessive and expensive debt capital to another related party and therefore substantial interest is paid in return, ${ }^{536}$ i.e. either to one shareholder of the borrower or a related party. The determination of related parties can be a difficult exercise to undertake. Although the payment can be formally made to a third party, complexities arise when a related party guarantees the debt. Guarantees come in many different forms and the relevance of the guarantee can be difficult to ascertain in practice. ${ }^{537}$

\footnotetext{
${ }^{534}$ Kaserer, Christoph. Restricting Interest Deductions in Corporate Tax Systems: Its Impact on Investment Decisions and Capital Markets, Technische Universität München, Center for Entrepreneurial and Financial Studies, 2008.

535 Council Directive (EU) 2016/1164 of 12 July 2016, laying down rules against tax avoidance practices that directly affect the functioning of the internal market. Available at: https://eur-lex.europa.eu/legalcontent/EN/TXT/?uri=uriserv:OJ.L_.2016.193.01.0001.01.ENG

${ }^{536}$ Barnes, Peter. Limiting Interest Deductions and Other Financial Payments, United Nations, 2014. Available at: http://www.un.org/esa/ffd/wp-content/uploads/2014/10/20140604_Paper7_Barnes.pdf.

${ }^{537}$ Ibid, 537.
} 
This work expects that the combination of the proposals regarding the cross-border taxation of interest income, alongside those which have already been proposed in relation to the taxation of dividend income, will reduce opportunities for tax abuse by default. Without prejudice to the fact that the proposals contained in this research conclude by allocating taxing rights regarding income derived from debt and equity in different ways according to different situations, the overall economic impact on either equity or debt will be more similar than the ones that exist under the current parameters. As stated, the only measure that will make the difference is the sovereign right of source countries to grant the right to deduct either fully or partially - the interest as a tax expenses at source.

\subsection{PRIMARY ECONOMIC ACTIVITY GENERATING INTERESTS}

Where does the primary economic activity of interests take place?

In order to determine where the economic activity related to interest takes place, it is necessary to look at the origin of the interest. As in the case of dividends, the view of this research is that the origin of the interest is shared between two countries. That is, the origin of the interest is partially located in the place where the debtor produces the interest income, e.g., the place in which he exercises a substantial business activity ${ }^{538}$ for which the debt capital is being used, and partially in the residence country of the lender. The country of residence of the lender has legitimate reasons to justify that the origin of the income is linked to its territory. The main reason is due to the fact that the payment of interest on debt capital is made possible by the use of the capital economically linked to the country of the lender, thus without the existence of that capital, ${ }^{539}$ non-debt capital will be available, and noninterest income will arise. In other words, if the lender had not invested its money, the investment would not have generated any interest. Kemmeren argues that interest is not

\footnotetext{
${ }^{538}$ Kemmeren, Eric C.C.M. Principle of Origin in Tax Conventions: A Rethinking of Models, The Netherlands, Pijnenburg, 2001.

539 OECD, Working Party No. 11 of the Fiscal Committee (France and Belgium). Report on the taxation of Interest, 1959. Available at: http://www.taxtreatieshistory.org/
} 
produced by capital but by the debtor's activity by means of the deployment of that capital. ${ }^{540}$ That argument is correct to an extent, but it is also possible to argue that debtors would not be able to deploy that capital if it was not for the existence of that capital. Kemmeren states that the origin of the interest is exclusively located in the place where the borrower/debtor produces the interest income. ${ }^{541}$ This research, deviating from Kemmeren's conclusion in this regard, states that it is also possible to find an economic nexus or link of the interest income with the country where the lender / creditor resides. Thus, as in the country of residence of the borrowers, the expectations of the countries of residence of the lenders to make the recipients of the income generated participate in the public expenses of their countries by reason of their possession are, for this research, valid.

Kemmeren has also stated that the place in which the debtor produces the interest income is not necessarily in the debtor's country of residence. ${ }^{542}$ However, if the debtor exercised its business activity in its state of residence, then the state of origin and the state of residence of the debtor naturally coincide. In the analysis of the problem, this research will use the basic and most common case of international borrowing where the creditor / lender is either a natural or a legal person. In both cases, the final beneficial owner of the interest resides in the other contracting state. According to the same reasoning, it is assumed in both situations that the country of residence of the borrower is the country in which the debt capital has been invested. Further complexities can exist, for example, when the final beneficial owner of the interests resides in a third country or when the debt has not been invested or expended in the country where the debtor resides. Those cases will not be considered here because the aim of this research is to propose a new core principle regarding the taxation of interest and the idea is that this research will focus on that main rule. Those cases will be left for further research on the topic.

Related debt, i.e. shareholders' loans agreements, and non-related debt are different. On the basis of special information, shareholders' loans are not simply granted alternatively to third party debtors on the general market depending on the interest rate and the risk of insolvency.

\footnotetext{
${ }^{540}$ Ibid, 539.

${ }^{541}$ Ibid, 539.

542 Ibid, 539.
} 
When a related party - a parent company or a shareholder - makes a decision to grant a related loan, it not only considers the expected interest and the security of the repayment, but it also simultaneously considers the expected returns from its participation in the debtor's equity. ${ }^{543}$ Thus, from an economic point of view, committing to a shareholder loan is the same as committing to an equity investment. ${ }^{544}$ This, considering the ongoing framework of rules that govern the international taxation of debt and equity, ends in the erosion of the source countries' tax bases as a consequence of the taxpayer's ability to influence the allocation of profits for tax purposes by choosing between debt and equity finance from subsidiaries. 545

Notwithstanding the differences between related and non-related foreign debts, both types of debt are considered by this research to be useful ways of financing businesses in developing countries' economies. Foreign related debt cannot be considered as unnecessary. One demonstration of this is the fact that it is a mechanism recognized under all rules that govern the limitation of deductibility of interest at source. Even more, all of them recognize the legal right to deduct (with some limitations), as a tax expense at source, the interest that is derived from foreign related debt. The availability and use of debt is widely recognized as an important element of a healthy business environment. Indeed, a lack of credit can deter economic growth. ${ }^{546}$ Developing countries should not give different tax treatment to both types of debt unless there is some abuse. If both agreements, i.e. unrelated loan or shareholder / related loan agreements, are agreed under commercial conditions, both are legitimate ways of being financed.

This research prefers to differentiate between beneficial and less or non-beneficial debt financing for businesses in countries that are undergoing a process of development. To this

\footnotetext{
${ }^{543}$ Schön, Wolfgan; Bakrozis, Andreas; Becker, Johannes; Beuchert, Tobias A; Boer, Martin; Dwenger, Nadja; Gerten, Andreas; Haag, Maximilian; Heidenbauer, Sabine; Hohmann, Carsten; Jehlin, Alexander; Kopp, Karin E.M; Kornack, Daniel; Lagdali, Nadia; Marguart, Christian; Mueller, Lukas; Castelon, Marta; Osterloh-Konrad, Christine; Paxinou, Natalia; Porhlhausen, Carlo; Redeker, Philipp; Röder, Eric; and Roesener, Astrid. Debt and Equity in Domestic and International Tax Law - A Comparative Policy Analysis, British Tax Review 2, 2014. ${ }^{544}$ Huizinga, Harry; Laeven, Luc; and Nicodème, Gaëtan. Capital Structure and International Debt Shifting, Journal of Financial Economics, Vol 88, 2007.

545 Ibid, 544.

${ }^{546}$ Barnes, Peter. Limiting Interest Deductions and Other Financial Payments, UN 2014. Available at: http://www.un.org/esa/ffd/wp-content/uploads/2014/10/20140604_Paper7_Barnes.pdf
} 
end, beneficial debt will be understood as debt that is invested or expended in the borrower country for business purposes and which creates productive activities within the borders of the borrower residence country. By way of contrast, non-beneficial debt will be understood as abusive debt or debt that is not being invested in the borrower country for business purposes, and if does, do not create productive activities within the borders of the borrower residence country. As has already been stressed in this research, cross-border debt must aid in the development of the host developing country.

\subsection{RENUNCIATION OF PRELIMINARY RIGHTS}

In practice, the Netherlands is probably the only developed country that has succeeded in negotiating DTCs with developing countries, where the main rule regarding interest taxation is that interest will be taxed only by the country in which the lender is resident, e.g. as is the case in the DTC between Bahrain and The Netherlands that was signed on 16 April 2008 and effective as from 1 January $2010,{ }^{547}$ the DTC between Georgia and The Netherlands that was signed on 21 March 2002 and effective as from 1 January $2004{ }^{548}$ the DTC between Kuwait and The Netherlands that was signed on 29 May 2001 and effective as from 1 January 2001; ${ }^{549}$ and the DTC between Macedonia and The Netherlands that was signed on 11 September 1988 and effective as from 2 January 2000. ${ }^{550}$ Notwithstanding that in the case of Bahrain and Kuwait, non-taxation at source has it origin in the fact that those countries do not tax that income under their domestic law, the cases of Georgia and Macedonian are somewhat surprising. It is known that the Netherlands seeks only the state of residence taxation in its treaties, but is willing to make concessions in treaties with developing

\footnotetext{
${ }^{547}$ Double Tax Convention between Bahrain and The Netherlands, 2008, Article 11: "1. Income from debt claims arising in a Contracting State and beneficially owned by a resident of the other Contracting State shall be taxable only in that other State."

548 Double Tax Convention between Georgia and The Netherlands, 2002, Article 11: “1. Interest arising in a Contracting State and paid to a resident of the other Contracting State shall be taxable only in that other State." 549 Double Tax Convention between Kuwait and The Netherlands, 2001, Article 11: "1. Interest arising in a Contracting State and paid to a resident of the other Contracting State shall be taxable only in that other State if such resident is the beneficial owner of the interest."

${ }^{550}$ Double Tax Convention between Macedonia and The Netherlands, 1988, Article 11: "1. Interest arising in a Contracting State and paid to a resident of the other Contracting State shall be taxable only in that other State if such resident is the beneficial owner of the interest."
} 
countries. Can this practice be considered as a proper tax policy in DTCs between developing and developed countries? According to the current research aims, the answer is yes. By granting only one level of taxation over cross-border interest income, the source / developing country could provide better conditions for foreign lenders and therefore facilitate easy access to foreign debt to their residents. That renunciation must be accompanied with certain conditions so as to grant easy access to foreign debt.

The elimination of withholding tax at source leads to the removal of probably the highest barrier for cross-border financing ${ }^{551}$ in DTCs between developing and developed countries. For the purposes of this research, the potential benefits for developing countries - acting as source countries or countries where the interest arises - as a result of the elimination of withholding taxes, definitely justifies the intent to agree on only one tier of taxation, i.e. only at the residence level. The conclusion of a DTC under the traditional parameters of interest taxation - two tiers of taxation, i.e. low withholding tax at source plus residence taxation maintains the same barriers that domestic legislation has in a scenario when there is no DTC. If source / developing countries renounce those rights, it will be less costly for borrowers to obtain debt capital from investors that are resident in developed countries. It also means the removal of the harmful effects of the additional costs that are associated with the practice of grossing up. ${ }^{552}$ As a consequence of the elimination of withholding taxation at source, the competition between lenders from both contracting states leads to a more level playing field and the most probable outcome will be, in addition to the reduction of the costs that are associated with debt financing, the free circulation of debt capital between the two contracting states.

The idea is that the source country will renounce its preliminary taxing rights in pursuit of certain benefits. As regarding dividends, the author's proposal is to facilitate and promote

\footnotetext{
${ }^{551}$ Mintz, Jack M. How Tax Barriers Stifle North American Capital-Market Efficiency -- and How Their Removal Would Deepen NAFTA Integration, 2003. Available at: https://www.cdhowe.org/sites/default/files/attachments/otherresearch/pdf/dismantiling\%20tax\%20barriers.pdf

552 OECD, Model Tax Convention on Income and Capital, 2017. Paragraph 2 of Commentary on Article 11: "In order to avoid that problem, creditors will, in practice, tend to shift to the debtor the burden of the tax levied by the State of source on the interest and therefore increase the rate of interest charged to the debtor, whose financial burden is then increased by an amount corresponding to the tax payable to the State of source."
} 
foreign investment within the borders of developing countries, while at the same time respecting an appropriate balance regarding the allocation of taxing rights. Hence, when, in a scenario between a developing and a developed country, the analysis of where the primary economic activity relating to the interest takes place has already been carried out, and, consequently, it is clear which country (borrower / source or lender / residence) deserves the preliminary rights to tax according to the origin of the income, then it is time to partially or completely renounce those rights with the aim of facilitating access to foreign debt by residents of the borrower / source / developing country. This can be achieved by granting an exemption at source and by giving exclusive taxing rights to the lender / residence country. Since this approach will be granted at the DTC level, it also ensures legal security and certainty for international lenders / investors and it assimilates the tax treatment of local and cross-border debt investors.

Following the approach outlined above, the borrower / source country must refrain from taxing interest at the first tier at source, i.e. making the existence of cross-border juridical double taxation impossible. By doing so, the proposal achieves only one tier of taxation - in the lender / residence country - and therefore, the income will economically taxed only once. The total elimination of even the possibility of the existence of cross-border juridical double taxation is in the hands of the borrower / source country and this can be done by relinquishing the right to tax the foreign lender on interest income.

Exemption at source will achieve an important reduction in the costs and barriers that are associated with cross-border debt financing. Furthermore, the corresponding free circulation of debt capital from the developed country to the developing country will effectively help in the development process of the borrower / source / developing country. The eradication of the withholding tax at source has the effect, from an economic perspective, of dismantling the greatest barrier for developing countries in relation to accessing cross-border debt. However, and according to this research's approach of granting beneficial tax treatment to foreign investors only when there is a real benefit for the source / developing country (access to cross-border debt that helps in the development process of the country), exemption at source will not be the rule in every case. 
This proposal differentiates between interest income that arises from non-beneficial debt, i.e. interest derived from debt capital that is not used in business activities in the borrower / source / developing country's economy (or interest that derives from tax-abusive debt transactions) and interest income that arises from beneficial debt, i.e. interest derived from debt capital that is used in business activities in the borrower / source / developing country. Thus, considering that interest is per se a deductible expense at the payer level and, since according to this proposal the idea is to eliminate taxation at source and therefore leave exclusive taxing rights only to the lender / residence country, it is essential, in order for this proposal to be successful, to avoid granting beneficial tax treatment to interest that is derived from debts that do not effectively aid in the development process of the borrower / source / developing country or to interest that derives from tax abusive transactions.

Source taxation will be applied to interest income that derives from debt capital not being used in business activities in the borrower / source / developing country, or interest that derives from tax abusive debt transactions. By reinstalling a withholding tax at source, the system will ensure real incentives for beneficial debt financing, i.e. debt capital that is effectively entering, with no tax abusive conditions, into the borrower / source / developing country's economy and, therefore, aiding in the development process of those countries. This measure does not prevent additional measures from being enacted in domestic legislation that pertains to restrictions on the deductibility of interest at source.

The transition from the primary to the secondary rule will be the consequence of the application by the borrower / source / developing country of an economic-substantive test, i.e. the impact of the foreign debt capital in the economy of the source country and of an arm's length test in order to determine if related debt operations are agreed and fulfilled on similar terms to those entered into by independent parties (in order to avoid mispricing). Furthermore, it is also contingent on an agreement nature test that will be used in order to determine if the interest derives from an actual debt instrument or if it derives from a hybrid instrument (so as to avoid base erosion and non-taxation). 
By renouncing this right, this proposal expects that the subscription of a DTC between a developing and a developed country will effectively encourage the residents of developed countries to finance businesses in developing countries. This research does not share the view of considering the approach of exempting interest income taxation at source and taxing interests income at the residence country as an approach that is more beneficial to the resident country than to the source country. DTCs must be beneficial to both signatory countries. While the source / developing country will benefit from the positive economic impact of the free circulation of debt capital from developed countries, i.e. more resources to create, for example, more business, and as a consequence, more employment and more development accompanied with revenue at source derived from VAT or taxation of business profits, the resident country must also receive certain benefits. What was achieved regarding dividends by removing barriers on the repatriation of benefits will be achieved in relation to interest by granting exclusive taxing rights to resident countries. This leaves countries of residence in a better position than the situation that they currently face under the current UN MTC. The fact that such exclusivity potentially means more revenue for resident countries when compared to the revenue expectations under the current UN MTC criteria means a benefit for the resident / developed country as a consequence of signing a DTC with a developing country.

\subsection{TESTS}

\subsubsection{ECONOMIC-SUBSTANTIVE TEST}

As was stated in the analysis of dividends, i.e. that it is impossible to analytically separate the equity of the host company from the underlying business activities of the host company, in this case it is also impossible to separate debt capital from such activities. The UN MTC must include a test that is able to determine the real impact of the foreign debt - debt provided to the borrower company by a foreign unrelated / related party - in the economy of the host country.

The aim of this economic substantive test is to differentiate between beneficial and less or non-beneficial foreign debt for countries that are in the process of development, i.e. debt as 
part of the source country's development process. It is necessary to determine the economic sector in which the debt is being used so as to determine if the foreign debt is actually having a positive effect on the economy of the source country.

Such test can only be properly developed by economists and its promulgation naturally depends on each host / developing country's economic characteristics. ${ }^{553}$ As regarding equity / dividends, it is impossible to define a concept of beneficial or non-beneficial debt capital applicable to all developing countries' economies. Although each economy has different needs, the idea here is to not restrict the concept of useful debt only to the main business sector of the country. All productive sectors must be considered.

With regard to the definition of beneficial and of non-beneficial debt, they will be left undefined in order for this to be decided by each country in accordance with the characteristics of their economies. The idea of this test is to promote access to foreign debt in order to finance business sectors that have a positive effect on the source country's economy and, consequently, to positively assist, either directly or indirectly, in the host country's development. In order to achieve this, it will be essential to ascertain the underlying business activities of the borrower company in the source country.

By differentiating between beneficial and non-beneficial debt, the test will help to determine to which debt the DTC will grant, from a tax perspective, better tax conditions. Thus, if the foreign debt is considered by the borrower residence country as being used in the generation of productive activities within the borders of the source country, the source country will exempt the foreign lender from tax at source by eliminating the withholding tax on interest income. On the other hand, the source country will tax interest income that arises from debt that is considered by the host country to be a non-beneficial debt with a withholding tax.

\footnotetext{
${ }^{553}$ See: Soto, Marcelo. Capital Flows and Growth in Developing Countries: Recent Empirical Evidence, OECD Development Centre, Working Paper $\mathrm{N}^{\circ} 160,2000$. Available at: http://www.oecd.org/development/pgd/1922938.pdf ; De Gregorio, José; Edwards, Sebastián; and Valdés, Rodrigo. Controls on capital inflows: do they work?, 2000. Valdés-Prieto, Salvador and Soto, Marcelo. The Effectiveness of Capital Controls: Theory and Evidence from Chile, 1998.
} 
The elimination of the first tier of taxation does not mean that the effective tax rate of the foreign lender will be lower than the effective tax rate in a scenario where the foreign lender is taxed on interest income not only by the borrower residence country but also by the lender residence country. Interest will still only be economically taxed once, but instead of being shared between the borrower residence country and the lender residence country, taxing rights will be afforded exclusively to the lender residence country. The most positive direct effect of this measure will be the reduction of costs for the borrower's residents in developing countries with the elimination of the grossing up practice, i.e. the elimination of the biggest commercial barrier to accessing foreign debt financing. The goal is to ensure that foreign lenders can compete in the borrower / source country without having to incur higher associated costs. The "gross up" practice cannot be a solution in this context. From one perspective, it eliminates the administrative barrier for the foreign lender, but from another perspective, there is an imposition of an important commercial barrier, i.e. the burden of the withholding tax is added as an additional cost of the loan.

Modern DTCs, instead of facilitating the access to foreign debt for domestic business, have only focused on the amount of taxing rights that are to be allocated to each contracting state. The exemption of interest income at source in DTCs between developing and developed countries is, according to the traditional way of thinking, contrary to the legitimate rights of developing countries.

As was stated in relation to dividends, the incorporation of a test is a means to go one step further than what is usually prescribed by DTCs. For the author, the relevance of the impact of the resources in the borrower / source / developing country is crucial for determining which debts must be treated preferentially in order to achieve: (1) access to foreign resources by businesses carried out in developing countries, and (2) incentives for lenders that are resident in developed countries to lend resources to businesses that are located in developing countries.

\subsubsection{ARM'S LENGTH TEST}


The risk of base erosion as a result of abusive debt financing agreements requires, in the first instance, the economic substantive test to be complemented with an arm's length test. The purpose of this test is to avoid mispricing by determining if related debt operations are agreed on similar terms to those entered into by independent parties. Thus, if the foreign debt passes the economic substantive test, it becomes necessary to determine if the interest that arises from that debt will have the effect of eroding the tax base of the borrower / source country. The interest deduction at source will erode the tax base of the source country if the terms of the loan have not been agreed in accordance with market conditions. Specifically, the test must analyse how much the borrowing entity could borrow if it were borrowing from an independent third party and if the price at which the amount is lent is similar to the pricing of independent party operations. Thus, the test is not only restricted to the quantum of the loan but also to the price at which the amount is actually lent. Notwithstanding that the ability to grant the right to deduct interest expenses at source is a matter for domestic law to determine, this proposal will deny the beneficial tax treatment granted in the DTC to the amount of debt that exceeds those parameters. As stated, when the sanction is a result of interest arising from non-beneficial debt, this measure does not prevent imposing additional measures in domestic legislation pertaining to restrictions on the deductibility of interest expenses at source.

The author is aware that the main problem of this proposal is the likelihood that it will be successfully applied by developing countries with low tax administrative capacities. What was solved in the case of equity investments by including an alternative temporary measure approach cannot be achieved in the case of debt. However, it is expected that the experience of developing countries at the domestic level with the application of thin capitalization rules and transfer pricing rules can help in developing this test. 


\subsubsection{AGREEMENT NATURE TEST}

In a scenario where the proposals that have been promulgated in this research regarding the taxation of dividends and interest are in force, the benefit for hybrid instruments can be even higher than those that are currently achieved under the existing parameters. The fact that the general rule regarding dividend taxation will be taxation at the first and only tier as business profits, in addition to the lack of a withholding tax at source and exemption at residence, plus the fact that the general rule regarding interest taxation will be deduction at source, no withholding tax at source, and taxation at the first and only tier at the residence makes the outcome a dream situation for planners. Thus, a measure to determine the nature of the agreement is essential. The idea is to neutralize the effects of hybrid arrangements at the DTC level. Under the proposed scenario, the exchange of information between the two contracting states is of crucial importance. If there is no certainty that what the borrower / resident country considers as interest will also be considered as interest by the lender / resident country, the risk of triple non-taxation will render this proposal useless.

The nature test therefore ends up being the analysis of the agreement and the determination of the tax consequences of the analysis. The source / borrower country must be sure that the tax treatment that the lender / resident country will give to the payment that arises from the agreement is in accordance with the real nature of the transaction. Adding an administrative burden to the source / borrower country does not seem, therefore, to be fair. Consequently, the source / borrower country will grant the tax benefits on the condition that the taxpayer provides a certificate issued by the tax authorities of the lender / resident country and which states that the payment from such an agreement is considered as interest and will be treated accordingly. In a DTC between a developing and a developed country, the administrative burden will be, in most cases, the responsibility of the developed country. According to the author's proposal, lenders resident in developed countries will be in a better position if one compares the proposed treatment with the treatment they currently receive under the current UN MTC rules. Thus, a greater administrative burden, i.e. the analysis of the agreement and the determination of the tax treatment of the corresponding payment, does not seem to be 
disproportionate, nor does it appear to be a measure that can affect the free access of foreign debt resources for businesses in developing countries.

The proposed rule respects the principle that anti-avoidance rules do not seek to address the characterization of the instrument itself. By requiring the certificate, the rule only seeks to address the tax consequences of the hybrid mismatch arrangement.

An alternative solution could be the inclusion of an obligation regarding the accounting standards used by residents (only from those involved in cross-border finance transactions) of contracting states that have a DTC according to the parameters proposed by the author. By doing so, it would be possible to ensure that transactions are catalogued and therefore treated equally in both contracting states.

Both measures follow the same trajectory as the BEPS Project. Even though the consequences of hybrid instruments would be more harmful in a scenario as that provided by the author, rather than in the BEPS proposal (the actual state of the art), the objective is nevertheless the same: avoiding base erosion through the operation of hybrid mismatch arrangements. Even more - in this specific case the conclusion of a DTC between a developing and a developed country - these measures must also act as rules that either allow or disallow access to the benefits of that DTC. Without these access rules, abusive tax structures could achieve deduction at source, no withholding tax, and exemption at residence.

\subsection{PROPOSAL FOR INTEREST TAXATION AND THE ELIMINATION OF DOUBLE TAXATION}

The approach of limiting the role of DTCs so as to allocate taxing rights when most domestic legislation already does this, does not seem to be enough however. What is more, it is aggravated by the fact that the actual system maintains the greatest barrier to cross-border debt financing from developed to developing countries: a withholding tax. 
Those who advocate improving the actual situation by increasing source taxation of interest income through a withholding tax rely on the benefit theory by considering the fact that the borrower resident country facilitates the lender's access to the market and therefore it deserves a portion of the taxing rights over the income. However, they forget that source countries have already taxed or will tax the profits that arise from businesses that are financed by those resources. The hypothetical revenue problem of source countries in such a scenario - deduction at source and the elimination of withholding tax - is mitigated, from a revenue perspective, by the fact that the easy access to foreign debt capital will increase the business profits of local businesses at source. However, the real benefit that this proposal is expected to bring is further assistance in the process of development.

Considering the fact that taxation of interest at source under domestic legislation would be the rule in the cases where there is no DTC in force, the limitation of sovereignty regarding interest taxation that source / developing countries will face by concluding a DTC with a developed country must be economically counterbalanced. The easy and affordable access to foreign debt (in terms of non-additional cost and administrative burdens) will make foreign debt comparable to local debt, thereby increasing the existence of foreign beneficial debt and therefore it will have the effect of aiding in the development process of the source / developing country's economy.

Thus, it can be affirmed that it is necessary to revise the system of interest taxation that is prescribed by the UN MTC so that it can then be advocated. The fact that DTCs that follow the UN MTC have no effect in granting easy and affordable access to foreign debt from developed to developing countries naturally reinforces this proposal. The UN MTC must include, amongst its aims, the granting of easy and affordable foreign debt for domestic business in developing countries with the expectation that this will assist in that country's development process.

This research proposes a new article regarding the taxation of interest income for the UN MTC, respecting a general framework in accordance with the following guidelines: 
(1) in order to incentivize the use of the UN MTC as the MTC to be followed in DTCs between developing and developed countries, the treatment of interest income must be beneficial for all actors, that is, to the lender residence country, to the borrower resident / developing country, to the lender, and to the borrower;

(2) the income must be economically taxed only once;

(3) taxing rights in relation to interest should be allocated in a coherent manner, irrespective of whether they arise in a developing or in a developed country; ${ }^{554}$ and

(4) The business that is carried out by the borrower company within the borders of the source country, the arm's length conditions of the agreement, and the avoidance of base erosion are the elements that must be considered in order to determine the real impact of the debt capital in the economy of the host country.

As a consequence, this research proposes the following modification to Article 11 of the UN MTC in order to regulate the taxation of income from interest in DTCs between developed and developing countries. This modification would read as follows:

Article 11

INTEREST

\section{Interest derived from beneficial debt arising in a Contracting State and paid to a resident} of the other Contracting State shall be taxable only in that other State.

2. However, interest may also be taxed in both Contracting States when they derive from non-beneficial debt, or if they derive from hybrid agreements, or if by reason of a special relationship between the payer and the beneficial owner or between both of them and some other person, the amount of the interest, having regard to the debt claim for which it is paid, exceeds the amount which would have been agreed upon by the payer and the beneficial owner in the absence of such relationship. In this last situation, paragraph 1 shall apply only to the last-mentioned amount.

\footnotetext{
${ }^{554}$ Strong taxation at source just because dividends arise in a developing country is not logical according to this research.
} 
3. The term "interest" as used in this Article means income from debt claims of every kind, whether or not secured by mortgage and whether or not carrying a right to participate in the debtor's profits, and in particular, income from government securities and income from bonds or debentures, including premiums and prizes attaching to such securities, bonds or debentures. Penalty charges for late payment shall not be regarded as interest for the purposes of this Article.

4. The provisions of paragraph 1 shall not apply if the beneficial owner of the interest, being a resident of a Contracting State, carries on business in the other Contracting State in which the interest arises, through a permanent establishment situated therein, or performs in that other State independent personal services from a fixed base situated therein, and the debt claim in respect of which the interest is paid is effectively connected with (a) such permanent establishment or fixed base, or with (b) business activities referred to in (c) of paragraph 1 of Article 7. In such cases the provisions of Article 7 or Article 14, as the case may be, shall apply.

5. Interest shall be deemed to arise in a Contracting State when the payer is a resident of that State. Where, however, the person paying the interest, whether he is a resident of a Contracting State or not, has in a Contracting State a permanent establishment or a fixed base in connection with which the indebtedness on which the interest is paid was incurred, and such interest is borne by such permanent establishment or fixed base, then such interest shall be deemed to arise in the State in which the permanent establishment or fixed base is situated.

6. The terms "beneficial" or "non- beneficial debt" used in this Article can be defined as follows: (a) Beneficial Debt: [the definition will be defined, according to their economic reality, by each developing country that subscribes this Model]; (b) Non-beneficial Debt: [the definition will be defined, according to their economic reality, by each developing country that subscribes this Model]. The definitions should be based on an economicsubstantive test and on an arm 's length test. 
7. To enjoy the one tier taxation level granted by this Article, the lender must obtain from the tax authorities of his country a certificate stating that for that country the payments of such agreement are considered as interest and therefore will be treated accordingly.

\subsection{RATIONALE OF THE PROPOSAL}

The main objective of this proposal is to grant, through the UN MTC, more beneficial tax conditions to lenders that are resident in developed countries other than the conditions that are normally granted to them by domestic legislation. The proposal is based on the assumption that developing countries are willing to relinquish taxing rights over interest payments if the outcome of that decision leads to a positive increase in beneficial foreign debt investment that will assist in that country's development process.

The current UN MTC approach requires developing countries to partially relinquish their rights without necessarily obtaining positive results in relation to easy and convenient access to foreign debt. That outcome is usually also achieved by domestic laws without requiring a substantial limitation of taxing rights over interest income by the host / developing country. The domestic law approaches of developing countries regarding cross-border interest taxation normally tends, as MTCs do, to reduce withholding tax.

The aim of this proposal is to reduce the three tax events of cross-border interest taxation, i.e. deduction in the hands of the borrower, source and residence taxation in the hands of the lender, to only two tax events, i.e. deduction in the hands of the borrower and residence taxation in the hands of the lender. By doing so, it will be possible for the lender to be treated

equally as in domestic borrowing situations. The proposal achieves not only a level playing field, but also the elimination of the withholding tax barrier, and therefore, the costly grossing-up phenomenon. 
Lastly, the proposal takes care of base erosion by negating beneficial treatment to interest agreed in tax abusive terms. Investors are also deprived of opportunities for tax abuse as a result of the beneficial tax treatment for equity and debt.

As has already been stated in relation to dividends, this proposal modifies one of the traditional principles of MTCs with regard to interest. The allocation of taxing rights is no longer the direct result of the analysis of the primary economic activity analysis. The primary economic activity analysis serves as a tool for developing countries to know what they have and what they will lose or gain by signing a DTC that is based on this new MTC approach.

Regarding interest, the result of the primary economic activity analysis was that, despite the strong logic of the position that the origin of the interest is always in the source country, because that is the country where the debtor produces the interest by using the debt capital to finance substantial business activity, it is also possible to find substantive arguments that suggest that the origin of interest may be located in the residence country, e.g. the existence of the capital.

Finally, instead of sharing taxing rights as a result of the foregoing, the proposal calls for the renunciation of those preliminary taxing rights by source / developing countries with the aim of achieving benefits for all actors. 


\section{PART VI. ROYALTIES: TESTS, NEW PROPOSAL, ROYALTIES TAXATION and the} UN MODEL

\subsection{PRELIMINARY CONSIDERATIONS: DEFINITION OF ROYALTIES}

The lack of a clear line between business income, service income, and royalty income is not conducive to achieving an appropriate approach for the purposes of DTCs in general. Furthermore, in DTCs concluded between developing and developed countries, it distorts the allocation of taxing rights in relation to royalty income. To a certain extent, this is due to the historical absence of proper concepts / definitions underlying the allocation rules that are contained in DTCs. However, it is worth pointing out that the 2017 UN MTC includes a new specific article for the treatment of technical services: new Article 12A. Notwithstanding the foregoing, a proper delimitation of the incomes that should be covered by the royalty article compared to those that should be covered by the business income article is still necessary.

Issues related to the definition are not exclusive to the UN MTC. Buitrago demonstrates the many misunderstandings that are related to the characterization of royalty income in her work on the concept of royalties in DTCs. ${ }^{555}$ The criteria for determining whether the proceeds of certain GRPs are to be regarded as royalty income in DTCs are somehow missing or they are not strong enough. The issues are further heightened by the use of civil law terminology that is used to define the income covered by the article, and the economic nature and functions normally related to passive income. Furthermore, she points out that the lack of delimitation is also related to the disagreement on the criteria regarding the allocation of taxing rights

\footnotetext{
555 Buitrago Diaz, Esperanza. El concepto de cánones y/o regalías en los Convenios para Evitar la Doble Imposición sobre la Renta, Valencia: Revista de Derecho Fiscal, 2007. p. 477.
} 
between two contracting states and the economic importance and justification of the withholding tax to the source state - two core issues that are duly analysed in this research.

Under the OECD MTC, developed countries are able to eliminate barriers to the trade in GRP that generate royalty income by allocating the taxing right to the country of residence of the beneficial owner of the payments i.e., no withholding tax at source. This approach, in absolute terms, is commensurate with this research. For developed countries, this approach has worked and there have been doubts about the necessity of including a separate article that deals solely with royalty income as opposed to rental income. The issue is a technical in nature and is therefore not a political question.

The disagreement is also about the reasons for and the underlying purposes of the distribution of the potential tax revenue. As to Buitrago, the current definition of royalties in DTCs and MTCs lacks a clear rationale. She contends that the lack of delimitation is, amongst others, due to the disagreement on two different issues. The first regards the basic allocation of taxing rights between two contracting states and the economic importance and justification of the withholding tax to the state of source. In this respect she points out that the origin of the royalties has been considered to be either in the state of residence or the state of the source, or in both. The residence state claims the provision of the intellectual element, the creation and maintenance of the intangibles, and the investment in research and development whilst the source state argues to be the place where the use or exploitation of intangible assets occurs, the immediate economic origin, and the country from where payments come from and not necessarily the first user of intangibles. In addition to the theory of the origin and recognition of an intellectual element, Buitrago sums up other grounds claimed for the allocation of royalties, such as the existence of a technological or technical component, the contribution to the development of a country or the payment for such development, as well as the promotion of culture. She points to how DTCs become an instrument for the direction of the economic and social policy of the states, in particular when the arguments in favour of 
the contribution to the development or the diffusion of culture and technology transfers are the leading ones. ${ }^{556}$

The second issue concerns the disagreement about the reasons for and underlying purposes of the distribution of the potential tax proceeds. Buitrago establishes that the arguments used whilst interpreting the royalty article, regarding its reasons and purposes, can be divided into two different groups. One set of reasons focuses either on the country in which the investment for the creation and safeguarding of the GRP were made, as well as the costs associated with the infrastructure used to do so (the state of residence), or in the country in which the GRP are used and the income arises (the state of source). The other elements used include: the recognition of an intellectual element, the existence of technological or technical elements, the contribution to the development of a country, the encouragement of a country's culture, and even the entry of copyrights or patents in a public register. In regard to this second set of arguments, Buitrago indicates that "it is difficult to specify the contribution that the reason for the distribution of income may represent in the interpretation of the concept of royalties, particularly in qualification problems". The contribution to the development or promotion of technology transfers can be a reason for the attribution to one or another country, but they do not explain in any case, for example, that the taxation of computer programs must be carried out as literary, technical, or scientific work due to the greater or lesser contribution to technological or cultural development. It could perfectly be argued that, to the extent that royalties are higher and are assigned to the state of source, the greater the investment that the latter could make in technology would also be, as Directive 2003/49 / EC seems to recognize with the attribution of royalties to Spain in favour of the technological development plan. But Buitrago agrees with Brokeling, indicating that the Directive is more in line with supporting the idea of economists on the substitution of technology provided by the development of local research, given that the more royalties come from a specific state, the fewer research and development activities are carried out in it, which in turn would decrease the payment of royalties to that state. But apart from this circumstance, which does not seem to give any

\footnotetext{
${ }^{556}$ Buitrago Diaz, Esperanza. El Concepto de Cánones y/o Regalías en los Convenios para Evitar la Doble Imposición sobre la Renta, CISS-Kluwer, Spain, 2007, p. 374.
} 
further light to the interpretation, the context of CDIs does not usually deduce a particular purpose of the royalties article. ${ }^{557}$

Because of this, Buitrago claims that it is important to have clarity on the core of the definition prior to the distribution, by doing so DTCs can overcome many issues related to the interpretation and characterization of the income. While her work sheds some light on the scope of the definition, tackling issues related to the characterization and how it impacts the developed and the developing world, this research looks into the allocation rules and the purpose of the allocation. This author believes that it is fundamental for developing countries to review the allocation rule by establishing how the contribution to the development can be made through DTCs and the royalty article. The contribution to development is from my perspective and for the purposes of this research, the most important element that should be taken into consideration for the determining the criteria for the allocation of taxing rights in a DTC between developing and developed countries, thereby justifying - contrary to historical developing countries approach - the attribution of exclusive taxing rights to the country of residence.

Despite the many issues engendered by the royalty income article, the OECD has stuck to the original scope of the article with very few corrections. The main one pertains to the exclusion from the definition of royalties of "payments for the leasing of containers" as well as "payments for the use of, or the right to use, industrial, commercial or scientific equipment". 558559560 The OECD Committee on Fiscal Affairs considered that the income generated from leasing industrial, commercial and scientific equipment should more logically fall under the rules in relation to taxing business profits (Article 7). ${ }^{561}$ Since then,

\footnotetext{
${ }^{557}$ Buitrago Diaz, Esperanza. El Concepto de Cánones y/o Regalías en los Convenios para Evitar la Doble Imposición sobre la Renta, CISS-Kluwer, Spain, 2007, p. 372.

558 While the definition of the term royalties in the 1963 Draft Convention and the 1977 DTC included "payments for the use of, or the right to use, industrial, commercial or scientific equipment", the reference to these payments was subsequently deleted from the definition. Vogel, Klaus. Klaus Vogel on Double Taxation Conventions, $3^{\text {rd }}$ ed., 1997. p. 782.

559 This was the 1992 OECD Model that finally removes any reference to "equipment" from the definition of Royalties.

560 Holmes, Kevin. International Tax Policy and Double Tax Treaties: An Introduction to Principles and Application, IBFD, 2007. p. 264.

${ }^{561}$ OECD, Model Tax Convention on Income and Capital, 2017. Paragraph 4 Commentary on Article 7.
} 
the definition of royalties found in the OECD MTC is framed in the following terms: "payments of any kind received as a consideration for the use of, or the right to use, any copyright of literary, artistic or scientific work including cinematograph films, any patent, trade mark, design or model, plan, secret formula or process, or for information concerning industrial, commercial or scientific experience". By so doing, the OECD Committee on Fiscal Affairs ensures that those types of business income are subject to the rules that are applicable to the taxation of business income.

The exclusion of payments relating to the leasing of containers points in the direction of restraining the scope of the royalty income definition to GRP that have an intellectual element. It seems that the OECD has correctly limited the definition to payments for the use of intellectual property, including copyrights, patents, know-how ${ }^{562}$ and secret processes. This definition of royalties relates, in general, to rights or property which constitutes different forms of literary and artistic property, the elements of intellectual property specified in the text of the article and information concerning industrial, commercial or scientific experience. Rent in respect of cinematograph films is also treated as royalties without prejudice to the fact that such films are exhibited in cinemas or broadcast on television. ${ }^{563}$

Notwithstanding the foregoing, many developed countries (including EU Member States) still follow the OECD MTC 1963 in this respect. ${ }^{564}$ In DTCs with or among developing countries, it is also common practice.

In an attitude that is only justified by a short-term tax policy view, the UN MTC still maintains a reference to "payments for the use of, or the right to use, industrial, commercial or scientific equipment" in its definition of royalties. The above might be the consequence of the UN's belief in the effectiveness of the UN MTC as a tool for increasing source taxation,

\footnotetext{
562 Association des Bureaux pour la Protection de la Propriété Industrielle (ANBPPI) states that know-how is: "all the un-divulged technical information, whether capable of being patented or not, that is necessary for the industrial reproduction of a product or process, directly and under the same conditions; inasmuch as it is derived from experience, know how represents what a manufacturer cannot know from mere examination of the product and mere knowledge of the progress of technique."

${ }^{563}$ Vogel, Klaus. Klaus Vogel on Double Taxation Conventions, $3^{\text {rd }}$ ed., 1997. p. 782.

564 Holmes, Kevin. International Tax Policy and Double Tax Treaties: An Introduction to Principles and Application, IBFD, 2007. p. 264.
} 
allowing Article 12 to function more effectively as a "source country rule". 565 That logic assumes as correct the idea that by leaving those payments under Article 12, source countries would be able collect more revenue. As is stated throughout this research, the author's view is that the free trade of GRP that generate royalty income could effectively aid in the development of the developing country with the aggregate and positive effect of collecting more revenue from the increase of, for example, business profits at source. There is a lack of analysis regarding the benefits of those source rules, i.e. withholding tax at source according to a broad definition of royalty income, compared with the potential benefits of development and revenue from business profits.

Since the OECD MTC and the UN MTC allocate taxing rights on royalty income differently (the OECD MTC grants exclusive taxing rights to the residence country, whereas the UN MTC allocates taxing rights between the source and the residence country by granting a limited withholding tax on a gross basis to the source country), the hypothetical elimination of the phrase "the use of, or the right to use, industrial, commercial or scientific equipment" from the UN MTC definition would result in a restriction of the source countries' right to tax. This was not a real concern for the representatives of developed countries in the OECD when the phrase was eliminated from the definition of royalties contained in the OECD MTC. The removal of these payments from the scope of Article 12 of the OECD MTC resulted in those payments falling within the scope of Article 7 on business profit. Therefore, from the perspective of the allocation of taxing rights and in accordance with the OECD MTC structure, nothing has changed. Because it is unlikely that the performance of these types of services can be considered as a permanent establishment, the residence country normally retains full taxing rights in relation to those services. In other words, the level of taxing rights of source countries in a DTC based on the OECD MTC has remained the same, even after the removal of those services from the definition of royalties. However, if the same phrase were to be removed from the UN MTC definition, the source country that has entered into a DTC based on the UN MTC would actually lose taxing rights.

\footnotetext{
565 United Nations, Committee of Experts on International Cooperation in Tax Matters. Eleventh Session, Geneva, October 2015. The character and purpose of Article 12 with reference to "industrial, commercial and scientific equipment” and software-payment related issues. Discussion Paper: Prepared by Wilkie, Scott J.
} 
The clarification of the tax treatment of income derived from services related to the leasing of containers and the use of containers, or the right to use industrial, commercial or scientific equipment, i.e. to treat them as business income and not as royalty income, is commensurate with the notion of taxing income according to its nature and origin.

Some developing countries insist on including business income within the scope of the royalty article. The reason for this is that source countries are tempted to use the broadest concept of royalties in order to extend their level of taxing rights. In the case of Chile, all of the DTCs in force include, under the scope of royalties, the phrase "payments for the use of, or the right to use, industrial, commercial or scientific equipment". ${ }^{566}$ It is noteworthy that although Chile is one of the more developed economies in Latin America (it has been an OECD member since 2010), it is still a developing country. Whether following the OECD approach to the allocation of royalty income is better for Chile is something that needs to be more intensely scrutinized. However, as was indicated above, Chile does not follow the OECD's approach in relation to the allocation of royalty income. Even more, some countries take the view that the expression "information concerning industrial, commercial or scientific

\footnotetext{
${ }^{566}$ DTC between the Republic of Chile and Australia signed the 10th of March of 2010; DTC between the Republic of Chile and the Republic of Austria signed the 6th of December of 2012; DTC between the Republic of Chile and the Kingdom of Belgium signed the 6th of December of 2017; DTC between the Republic of Chile and Brazil signed the 3rd of April of 2001; DTC between the Republic of Chile and the Government of Canada signed the 21st of January of 1998; DTC between the Republic of Chile and the Republic of Colombia signed the 19th of April of 2007; DTC between the Republic of Chile and the Republic of Korea signed the 20th of October of 2003; DTC between the Republic of Chile and the Republic of Croatia signed the 24th of June of 2003; DTC between the Republic of Chile and the Kingdom of Denmark signed the 10th of February of 2005; DTC between the Republic of Chile and the Republic of Ecuador signed the 26th of August of 1999; DTC between the Republic of Chile and the Kingdom of Spain the 7th of July of 2003; DTC between the Republic of Chile and the Republic of France signed the 7th of June of 2004; DTC between the Republic of Chile and Ireland signed the 2nd of June of 2005; DTC between the Republic of Chile and Malaysia signed the 3rd of September of 2004; DTC between the Republic of Chile and New Zealand signed the 10th of December of 2003; DTC between the Republic of Chile and the Republic of Paraguay signed the 30th of August of 2005; DTC between the Republic of Chile and the Republic of Peru signed the 8th of June of 2001; DTC between the Republic of Chile and the Republic of Poland signed the 27th of March of 2004; DTC between the Republic of Chile and the Republic of Portugal signed the 7th of July of 2005; DTC between the Republic of Chile and the United Kingdom of Great Britain and Northern Ireland signed the 12th of July of 2003; DTC between the Republic of Chile and Russia signed the 19th of November of 2004; DTC between the Republic of Chile and the Kingdom of Sweden signed the 4th of June of 2004; DTC between the Republic of Chile and the Swiss Confederation signed the 2nd of April of 2008; DTC between the Republic of Chile and the Kingdom of Thailand signed the 8th of September of 2006.
} 
experience" includes certain technical services. ${ }^{567}$ The inclusion of the new Article 12A goes in the direction of taxing service / business / active income in a separate Article but in the same way as royalties.

The allocation of royalty income is intertwined with issues of income characterization. This is an Achilles heel in the application of DTCs between developed and developing countries and in DTCs between developing countries. This is due to the fact that developing countries tend to broaden the scope of the royalty article by including payments related to technical assistance, technical services and certain other services. This makes income characterization more complex and it creates a grey area due to the already complex issues inherent in characterizing the concept of know-how. ${ }^{568}$ In this type of contract, one of the parties agrees to impart to the other its special knowledge and experience which remains unrevealed to the public. As has been confirmed by Vogel, it is recognized that the grantor is not required to play any part itself in the application of the formulas granted to the licensee and that grantor does not guarantee the results thereof. ${ }^{569}$ This type of contract can be contrasted with contracts for the provision of services. Payments received as consideration for services rendered do not constitute royalties. However, in practice, know-how contracts normally include some service elements. The most typical case is that of a franchising contract. In these types of contracts, the franchisor imparts its knowledge and experience to the franchisee, as well as some technical assistance which in certain cases is backed up with financial assistance and the supply of goods. ${ }^{570}$ Thus, in the case of mixed contracts, it is necessary to determine the applicable tax rule according to the information contained in the contract or by means of a reasonable apportionment. However, and especially if the source country is a developing country, if one part of what is being provided predominantly constitutes the principal purpose of the contract and the other part is merely an ancillary and unimportant part of the contract, then it is justifiable to apply the OECD tax rule included in

\footnotetext{
${ }^{567}$ United Nations BEPS Project: Taxation of Services. Report by Coordinator Liselott Kana. Committee of Experts on International Cooperation in Tax Matters Seventh Session, 2016. Available at: https://www.un.org/esa/ffd/wp-content/uploads/2016/10/12STM_CRP1_Services.pdf

${ }_{568}$ Buitrago Diaz, Esperanza. El concepto de cánones y/o regalías en los Convenios para Evitar la Doble Imposición sobre la Renta, Valencia: Revista de Derecho Fiscal, 2007. p. 85.

${ }^{569}$ Vogel, Klaus. Klaus Vogel on Double Taxation Conventions, $3^{\text {rd }}$ ed., 1997. p. 783.

${ }^{570} \mathrm{Ibid}, 570$.
} 
the commentaries on the characterization of the payments following that of the main part in relation to the whole amount of the consideration. 571

The argument behind the UN MTC, in the case of business income that is treated as royalty income and also on the basis of the approach of some developing countries of considering the consideration for services rendered as royalty income, is a policy that is (incorrectly) aimed at protecting the tax base of countries that import intangibles, i.e. normally developing countries. Under this misconception, developing countries demonstrate that they are interested in a broad concept of royalties so that they can levy tax on more income at source. It does not make sense for the fiscal policy of a developing country, with regard to the agreement of a DTC with a developed country, to be based on short-term revenue expectations rather than on the country's development. For the author, this is not a reasonable policy and it is a consequence of having lost sight of the role, effects and aims of DTCs between developing and developed countries. In Latin America, this view has been highly criticized by Buitrago and Hoyos. In their view, the policy adopted by the Andean Community and the way that policy was implemented in Colombia has not helped in the development of the country. One of the issues they pointed out was the shift of the tax cost to the domestic taxpayers, obliging them to engage in grossing up, which in turn makes the technical and technological development more expensive since they cannot be credited or deducted. ${ }^{572}$ And, this comes only when the additional and burdensome administrative requirements for the registration of the contracts and of payments abroad have been complied with. Furthermore, in her view, the conflict simply grows, considering the terrible mischaracterization issues related to the inclusion of technical services, technical assistance and other services in the definition of royalties for the purposes of tax treaties. As for Buitrago, the high risk of withholding taxes resulting in excessive double taxation is

\footnotetext{
571 Ibid, 570.

572 See: Buitrago Diaz, Esperanza. Propiedad intelectual en la mira de la política comercial y tributaria. Lecciones de Derecho Tributario Inspiradas por un Maestro (en homenaje a don Eusebio González García), 2010; Buitrago Diaz, Esperanza. Políticas Públicas y Tributación Internacional, Foro Economía del Derecho de Autor, 2010; Buitrago Diaz, Esperanza. Propiedad Intelectual y Desarrollo tras el Acuerdo sobre los ADPIC, Revista EPI, 2009.
} 
aggravated by the fact that withholding taxes are imposed on gross revenues, whereas income taxes are imposed on net earnings / profits. ${ }^{573}$

By broadening the definition of royalties, the UN has managed to broaden the base. This intention is very clear in the MTC, which states that it favours the retention of greater "source country" taxing rights under a tax treaty - the taxation rights of the host country of investment - in comparison to those of the "residence country" of the investor. ${ }^{574}$ The royalty article emphasizes this approach by allocating taxing rights to both countries: the source country and the residence country. The broadening of the tax base is therefore a highly conflicting issue in this debate.

An example of the above is illustrated by Kim Brooks in his work entitled: "Tax Treaty Treatment of Royalty Payments from Low-Income Countries: A Comparison of Canada and Australia's Policy". ${ }^{575}$ This study begins from the premise that high income countries (developed countries for the purposes of this research) should further the cause of reducing global inequality by ensuring that in their DTCs with low income countries (developing or not developed countries for the purposes of this research) they do not usurp much-needed revenues by reducing the ability of the low income country to collect tax on income with a source in that low income country. The statement quoted assumes, as an underlying premise, that developed countries should use their DTCs to assist developing countries and that tax revenue is what developing countries need. Even though there are some generous voluntary practices, it is not a principle that can justify such a tax policy. A DTC must be designed on the basis of the real economic benefits that the conclusion of such an agreement can provide to each signatory country, which for the author, in the case of developing countries, cannot be anything other than development.

\footnotetext{
573 Buitrago Diaz, Esperanza. The impact of international direct taxation on the economic exploitation of copyrights, SERCI, 2010. Available at http://www.serci.org/2010/buitrago.pdf

${ }^{574}$ United Nations, Department of Economic and Social Affairs, Model Double Taxation Convention between Developed and Developing Countries, 2017.

575 Brooks, Kim. Tax Treaty Treatment of Royalty Payments from Low-Income Countries: A Comparison of Canada and Australia`s Policies, eJournal of Tax Research, Vol 5, 2007.
} 
What is surprising is the fact that the UN approach is shared not only by developing countries but also by some BRIC countries. In 2001, the OECD Committee on Fiscal Affairs led a study based on the characterization of 28 e-commerce transactions. A working group of the OECD determined that only three of those transactions could be identified as royalties (under the UNMTC shared taxation between the source and the residence country; under the OECD MTC exclusive rights to tax for the residence country), while the rest could only be characterized as business profits ${ }^{576}$ (under the UN and the OECD MTCs these are not taxed at source unless the taxpayer has a permanent establishment in the source country). The Ministry of Finance of India report concluded that 14 out of the 28 e-commerce transactions could be categorized as royalties. ${ }^{577}$

The case of Brazil is even more extreme. Although not a policy shared by the UN, it is worth mentioning that Brazilian DTCs include fees for technical assistance and technical services in their definition of royalties. Until 2014, the rule was applied without any distinction being made by the Brazilian tax authorities. The criteria changed two years after the decision that was adopted by the Superior Court of Justice in the Special Appeal number 1.161.147/RS ${ }^{578}$ where, in a case involving the contracting of services from overseas without any transfer of technology, the understanding prevailed that Article 7 of the DTC should be applied. For the author, from the perspective of a DTC's structure, this is a significant problem as it is not only a misconceived interpretation of the UN MTC but also a way of thinking about developing countries' (and even BRIC) negotiators.

As indicated above, one of the main issues in the UN context is how to increase "source" country taxation. ${ }^{579}$ The Committee has referred to a number of alternatives for doing so, including a provision for permanent establishment services and giving a broader scope to the definition of royalties than that which is currently applicable in the context of the OECD.

\footnotetext{
${ }^{576}$ OECD. Tax Treaty Characterisation Issues Arising from E-Commerce and Taxation, 2001. Report issued by the Technical Advisory Group on Treaty Characterisation of Electronic Commerce Payments to Working Party $\mathrm{N}^{\circ} 1$ of the OECD Committee on Fiscal Affairs, 2001, Annex 2.

577 India. Report of the High-Powered Committee on Electronic Commerce and Taxation, 2001, Annex 2.

${ }^{578}$ Dated 17 May 2012.

${ }^{579}$ See for instance the reference to the works of the Eighth Session of the UN Committee of Experts in Tax Matters, 2016.
} 
The current trend seems to be towards the inclusion of all types of tangible assets instead of the odd classification of industrial, commercial or scientific equipment. ${ }^{580}$ This goes far beyond the proposals made by the UN to the royalty article in $2016^{581}$. This approach therefore needs to be rebalanced.

A clear scope is absolutely necessary if the idea is to develop a fair approach to the allocation of taxing rights in DTCs between developing and developed countries. This, in addition to the analysis of where the primary economic activity generating royalties arises and the evaluation of the real economic benefits that the transfer of technology can create in the source country, are, for the author, the core elements of a fair MTC regarding the allocation of taxing rights in relation to royalty income. This is because tax treaties in developing countries should not simply focus on only implementing technical solutions to technical tax problems, but should also respond to policy and contribute to development.

For the author, the statement that the origin of royalties is shared between the two countries is valid regarding the GRP that are covered by the definition. Furthermore, in all cases it should be possible to more or less identify the relationship between the time and resources that have been invested by the owner in developing those intangibles in its country of residence, and of the conditions provided by the source country to exploit the intangible, with the royalty income.

Despite there being a number of arguments that could be raised as to the proper definition of royalties, this research will assume that the definition provided by the OECD MTC is accurate. The UN MTC offers a broader definition of royalties, whilst the OECD MTC has curtailed its definition to include to some GRP which are primarily of an intangibleintellectual character.

\footnotetext{
${ }^{580}$ United Nations, Committee of Experts on International Cooperation in Tax Matters Twelfth Session, 2016. Available at: http://www.un.org/esa/ffd/wp-content/uploads/2016/10/12STM_CRP8_Royalties.pdf, p. 11.

${ }^{581}$ Ibid, 581.
} 
For the sake of clarification, the adjusted definition will be as follows: "payments of any kind received as a consideration for the use of, or the right to use, any copyright of literary, artistic or scientific work including cinematograph films, any patent, trade mark, design or model, plan, secret formula or process, or for information concerning industrial, commercial or scientific experience" ${ }^{582}$ In other words, the exploitation - payments of any kind received as consideration for the use or the right to use - of rights or property constituting different forms of literary and artistic property, the elements of intellectual property specified in the definition and information concerning industrial, commercial or scientific experience, constitute royalties.

It is undeniable that there is still a need for further precision. For the purposes of this research, however, this definition is sufficient as it draws a reasonable line between royalty income and active income (income derived from services and business). This notwithstanding, the author does not share the view that the incorporation of Article $12 \mathrm{~A}$ in relation to the allocation of taxing rights (a subject not discussed in this work because it relates to the allocation of taxing rights of active income), helps to curtail the definition of royalties. Ultimately, if some business incomes are included within the scope of Article 12, that should not distort the outcome of this proposal, namely that, unless the income is covered by Article $12 \mathrm{~A}$, most of those forms of income should not be taxable at source either as business income (Article 7) or as royalty income (Article 12).

\subsection{TOTAL ALLOCATION OF TAXING RIGHTS TO THE COUNTRY OF RESIDENCE OECD MTC}

The OECD MTC approach of fully allocating taxing rights to the country of residence, i.e. developed countries where residents possess technology, has its origin in the economic benefits provided to each signatory country as a result of the DTC. In the period immediately after World War II, Western European countries needed to attract technology from the United

${ }^{582}$ OECD, Model Tax Convention on Income and Capital, 2017. Article 12 paragraph 2. 
States in order to rebuild and modernize their war-ravaged economies. ${ }^{583}$ Regardless of the bargaining position of the United States, the ultimate goal of the DTCs concluded during that period was to contribute to the development of European economies. This was not achieved by granting more taxing rights, but rather by facilitating the transfer of technology. ${ }^{584}$ Therefore, in order to facilitate the trade of GRP that generate royalty income, European countries were willing to give up their taxing rights in relation to this royalty income.

This logic simply reaffirms what this research states concerning the study that was carried out by Kim Brooks. ${ }^{585}$ The approach of the DTCs concluded immediately after World War II was not to usurp much-needed revenues by reducing the ability of source countries to collect tax, the aim was rather to grant real economic benefits to those source countries. This was done by concluding DTCs with countries where the technology was developed. The underlying principle behind that policy is the one that must now govern the conclusion of DTCs between developing and developed countries.

The same can be said regarding Lee Sheppard's statement in his publication "Revenge of the Source Countries, part IV: Who Gets the Bill?", where he affirms that the international tax system has been set up in order to preserve residence-based taxation by rich capital-importing countries at the expense of everyone else. ${ }^{586}$ It seems to this author, based on the remarks mentioned above, that the facts present in that statement may not be entirely correct. The origin of the approach to the allocation of taxing rights regarding royalty income demonstrates that the original underlying purpose was the economic benefits that source economies could obtain by concluding a DTC with a developed country, rather than the amount of revenue they could collect. If, according to that logic, a DTC determines that residence countries should maintain their rights to tax, then there is nothing wrong with that decision. However, Lee Sheppard's statement is accurate from the perspective of the

\footnotetext{
${ }^{583}$ Irish, Charles R. International Double Taxation Agreements and Income Taxation, The International and Comparative Law Quarterly, Vol 23, 1974.

${ }^{584}$ Vogel, Klaus. Klaus Vogel on Double Taxation Conventions, $3^{\text {rd }}$ ed., 1997. p. 1163.

585 Brooks, Kim. Tax Treaty Treatment of Royalty Payments from Low-Income Countries: A Comparison of Canada and Australia's Policies, eJournal of Tax Research, Vol 5, No. 2, 2007.

${ }^{586}$ Sheppard, Lee. Revenge of the Source Countries, part IV: Who Gets the Bill?, Tax Note International, 2005. p. 411.
} 
allocation of taxing rights according to the international tax criteria used by the UN MTC since then, i.e. the determination of the level of taxing rights according to revenue expectations rather than the real economic benefits. The full allocation of taxing rights to the resident exporting country can be regarded as fair if the conclusion of the DTC engenders a real economic benefit to the source importing country, i.e. in the context of this research, to the developing country.

The Human Development Report issued by the UN in $2002^{587}$ stated that, in that year, the residents of countries with high human development were granted an average of 250 patents per million people. By way of contrast, only seven patents per million people were granted in medium human development countries and no patents were granted in low human development countries. As a consequence, similar disparities can be observed in relation to the receipt of royalty and licence fees. In 2003, in high human development countries, an average of approximately US\$80 per person was received from royalties and licence fees. By way of contrast, an average of only 30 cents per person was received in medium human development countries and no royalties were received in low human development countries. 588589 Thus, due to the non-reciprocal exchange of GRP that generate royalty income between developed and developing countries, if the transfer from the developed to the developing country does not bring about any real economic benefits to the source country, subscribing to a DTC with a developed country under an actual UN MTC means the maintenance of domestic law barriers for trade in GRP, and also, a mechanism to transfer taxing rights from developing to the developed countries.

Exclusive taxing rights for the residence country facilitates the transfer of GRP that are able to generate royalty income from suppliers in resident countries (developed countries in the context of this research) to investors in source countries (developing countries in the context of this research). As in the case of interest income, one of the main arguments in support of

\footnotetext{
${ }^{587}$ United Nations, Human Development Report, 2002. Available at: http://hdr.undp.org/sites/default/files/reports/263/hdr_2002_en_complete.pdf 588 Ibid, 585.

${ }^{589}$ Brooks, Kim. Tax Treaty Treatment of Royalty Payments from Low-Income Countries: A Comparison of Canada and Australia's Policies, eJournal of Tax Research, Vol 5, No. 2, 2007.
} 
this approach is if withholding taxes are imposed on royalties, the licensor will demand that the tax must be paid by the licensee in the source country, i.e. grossed up.

In order for the transfer of GRP that generate royalty income to be regarded as beneficial, it needs to be useful to the source country, otherwise it does not make sense for source developing countries to give up their taxing rights. Thus, if there is a real economic benefit to the source developing country, this proposal supports the idea of granting unlimited and exclusive taxing rights to the residence country. In so doing, international trade and investment, in this specific case, the transfer of royalty-generating GRP, e.g. technology, will be unhindered.

\subsection{PRIMARY ECONOMIC ACTIVITY GENERATING ROYALTIES}

One of the main questions underlying the taxation and allocation of royalty income pertains to the origin of royalty income. Where does the primary economic activity of royalties take place? In order to determine where the economic activity related to royalties takes place, it is necessary to look at the origin of royalties. As in the case of dividends and interest, the view of this research is that the origin of royalties is shared between two countries. That is, the origin of income from royalties is partially in the place where the investment for the creation (or the cost associated with the acquisitions), and the costs related to safeguarding, as well as the costs associated with the infrastructure used for, the creation and conservation of royalty-generating GRP income were made; and partially in the place where the GRP that generate royalty income is used. This is determined on the basis of the conditions provided by the source country to exploit those GRP, i.e. the infrastructure, the educated workforce that helps in the exploitation of those GRP and, naturally, the market place for the licensee. Thus, although one should acknowledge the legitimate rights of the source country - because the payment of royalties is the direct consequence of the use of those GRP - it is undeniable that those payments are also possible due to the existence of those GRP. In other words, if the licensor had never developed or acquired the GRP, it would not have generated any income. Thus, as in the country of residence of the user of the GRP, the expectation of the 
country of residence of the developers or owners of the GRP to make the income generated participate in the public expenses are, for this research, valid.

Eric Kemmeren opines that the origin of royalties lies exclusively in the place where it has been produced. ${ }^{590}$ However, he postulates that for the purposes of the allocation of taxing rights, royalties should be divided into four parts: (1) compensation for write-offs on the original market value of the intangible property concerned; ${ }^{591}$ (2) compensation for maintaining the intangible property; (3) compensation for bearing the risks; and (4) an interest component. ${ }^{592}$ In so doing, he concludes that some (1, 2 and 3 ) of these components must be attributed to the country in which the owner of the intangible performs the activity, i.e. typically the country in which the intangible property has been developed and, therefore, it should be taxed accordingly. He believes that the state where that development is carried out should be considered to be the country of origin, i.e., the residence country. In addition to all of foregoing, Kemmeren argues that the interest component (4) must be attributed to the country in which the intangible is being used, i.e. the source country. He proposes, by way of an example, that a standard could be included in the DTC on the basis of which the interest part could be determined, e.g. Libor plus X.

Kemmeren solved the problem of the legitimacy of source country taxation by dissecting the retribution into more than one element. For this research, it seems that he could not overcome the paradigm that the user of the GRP cannot simply produce royalty income, i.e. in his words, "the overwhelming relevance of the intellectual element in the production of the income". The underlying reasoning behind that conclusion is that the developer or owner of the GRP produces royalty income through the exploitation of those GRPs and the user of those GRP only uses the intellectual element derived from someone else in order to produce business income. Kemmeren's reasoning begins by assuming that the economic activity that

\footnotetext{
${ }^{590}$ Kemmeren, Eric C.C.M. Principle of Origin in Tax Conventions: A Rethinking of Models, The Netherlands, Pijnenburg, 2001.

${ }^{591}$ The write-off is based on the costs of the production of the intangible property.

${ }^{592}$ For Kemmeren this element only exists in the case of periodic payments. He correctly states that a person who receives royalty income for the use or the right to use an intangible property is economically receiving a lump sum in a deferred way. Therefore, an interest component is probably undeniable.
} 
gives rise to the income is related to the creation of the intangible property. He literally states that "the cause of the royalty income received is the creation of the intellectual property". ${ }^{593}$

An alternative approach, similar to Kemmeren's, may be to allocate taxing rights depending on the right of the owner of the GRPs (developer or acquirer) to deduct the expenses of the development or to depreciate the costs associated with the acquisition of those GRPs in its country of residence. It could be argued that preferential rights should be given to the country of residence until the expenses related to the development or the costs associated with the acquisition of those GRP are covered by the inflows deriving from the licence agreements. It could also be required that a reasonable profit margin after costs be generated.

Notwithstanding that the outcome of Kemmeren's proposal, or the alternative, it must be asked whether they can be considered as fair (i.e. to grant exclusive taxing rights to the residence country over three of the four elements of the retribution and exclusive taxing rights to the source country over only one of them; or to grant preferential taxing rights to the residence country only until the expenses of the development or costs associated to the acquisition of those GRPs has been already covered). This author suggests that, from an allocation of taxing rights perspective, and with the aim of eliminating barriers to the trade in those GRP so as to achieve real benefits for source / developing countries, a fair result would be better achieved by granting exclusive taxing rights to the residence country. The country of source must renounce those rights. Both proposals share the same problem, that despite the level of source taxation which will nevertheless occur, the problem of the "gross up" practice will remain an enormous barrier to the free circulation of GRP that generate royalty income between developed and developing countries.

Kemmeren also stated that the place in which the intangible has been produced is not necessarily the country of residence of the owner of the intangible. This is a quite a common topic in the discussion relating to the taxation of royalties and a great deal has been written about issues related to the recipient and the beneficial owner, as well as the many abuses of

\footnotetext{
${ }^{593}$ Kemmeren, Eric C.C.M. Principle of Origin in Tax Conventions: A Rethinking of Models, The Netherlands, Pijnenburg, 2001.
} 
DTCs on this basis. BEPS deals with that situation. Considering that the aim of this research is only to focus on the allocation of GRP that generate royalty income under DTCs concluded between developing and developed countries, it will be assumed that the basic case of an international transfer of GRP in which the owner of those GPR (developer or acquirer) whether a natural or legal person - resides in the same country where the expenses and costs associated with those GRP have been incurred. Exceptional situations can affect the analysis of the main rule. Those cases will be left for further research on the topic, however. The case

does not consider situations where the GRP have not been exploited in the country where the licensee is resident. It indeed assumes that the country of residence of the licensee is the country in which the GPR that produce the income is exploited.

\subsection{RENUNCIATION OF PRELIMINARY RIGHTS}

What happens in practice differs from this research proposal regarding the taxation of royalty income in DTCs between developing and developed countries, i.e. one tier of taxation. By way of contrast to interest income, it is difficult to find DTCs signed between developing and developed countries where the source country waives the right to tax royalty income. What is common in DTCs between developed countries, however, is not common in those DTCs signed between developing and developed countries.

The elimination of a withholding tax at source, as regarding interest, means the elimination of probably the highest barrier to the cross-border transfer of GRP that generate royalty income from developed to developing countries. The author is convinced that the potential benefits for developing countries - acting as source countries or countries where the GRP that are developed in developed countries are exploited - as a result of eliminating the withholding tax, would definitely justify the intention to agree on only one tier of taxation, i.e. only by the country where the GRP have been developed or acquired / the residence country. The conclusion of a DTC under the UN MTC's conception of royalty taxation - two tiers of taxation, i.e. low withholding tax at source plus residence taxation - would maintain the same barriers imposed by domestic legislation. 
Furthermore, as was already pointed out in relation to dividends and interest, this change would make it less costly for residents in developing countries to access, for example, useful technology developed by residents of developed countries. As a consequence, this would lead to more chances for these countries to move away from being categorized as developing countries and they would gradually move, through development, towards being considered as belonging to the category of developed countries. The grossed-up practice regarding royalty payments might be, as regards interest, the greatest barrier to the free circulation of intangibles between developed and developing countries. The removal of withholding taxes on royalties - source taxation - would benefit developing countries since it would eradicate the additional costs (gross up) associated with the use of GRP covered by the royalty article.

In so doing, the source country would renounce its preliminary taxing rights in pursuit of certain benefits. As discussed in relation to dividends and interest, the author's proposal is to facilitate and promote foreign investment in developing countries, which could be achieved by ascertaining the appropriate approach in relation to the allocation of taxing rights. Hence, in a scenario between a developing and a developed country, the analysis of where the primary economic activity that relates to the royalty income takes place is already carried out and, therefore, it will be clear which country, i.e. (1) the country where the investment for the creation or the cost associated with the acquisitions, and the costs related to safeguarding, as well as the costs associated with the infrastructure used for the creation and conservation of GRP that generate royalty income were made; or (2) the country where the GRP that generate royalty income are used deserves the preliminary right to tax according to the origin of that income. It is now time for developing countries to give up those rights with the aim of facilitating the access of their residents to, for example, technology developed by the residents of developed countries. This can be achieved by granting an exemption at source and endowing the residence country with exclusive taxing rights in relation to that technology.

Following the approach outlined above, the source country must refrain from taxing royalty payments made to the residents of developed countries with which they have concluded a 
DTC. If this is the case, cross-border juridical double taxation would be eradicated. This proposal relies on one tier of taxation at the level of the beneficial owner of the GRP, i.e. the country where the investment for the creation, or the cost associated with the acquisitions, and the costs related to safeguarding, as well as the costs associated with the infrastructure used for the creation and conservation of the GRP that generates the royalty income were made. That income will only be economically taxed once. The total elimination of crossborder juridical double taxation depends on the source country and can be done by relinquishing the right to tax the foreign licensee on any royalty income.

As indicated previously, a great deal has been written about the issues surrounding the recipient and the beneficial owner, as well as the many abuses of DTCs on this basis. Both the OECD MTC and the UN MTC rely on the beneficial owner concept in order to avoid granting benefits provided in the MTC to taxpayers that do not deserve those benefits - a phenomenon known as 'treaty shopping'. This mechanism is founded on the premise that the real economic recipient or owner of the GRP is a resident of the residence country or the country where the intangible has been developed. Thus, if this is not the case, the source country / the country where the intangible is used may tax (in the case of the OECD MTC) or tax without limitations (in the case of the UN MTC) the royalty payments to a resident of the residence country / country where the intangible has been developed.

This proposal goes one step further in relation to the functionality of the beneficial owner concept. A proper backstop for a DTC between developing and developed countries should not be restricted by the residence, or lack thereof, of the real economic recipient or owner of the GRP. This proposal attaches more weight to the economic impact of the transaction in the economy of the source country / country where the GRP are used.

Exemption at source can achieve an important reduction in the costs and barriers associated with the cross-border transfer of GRP that generate royalty income, for example technology, from developed to developing countries. Accordingly, exemption would effectively help in the development process of the source country / country where the GRP are used. In line with what was stated in relation to interest, the eradication of the withholding tax at source 
removes the greatest tax barrier for developing countries regarding access to technology in developed countries, at least from an economic perspective. This, combined with the main principle of this proposal, i.e. to grant beneficial tax treatment to foreign investors only when there is a real benefit for the source / developing country, results in the logical outcome that the benefit of exemption at source will only be granted to the cross-border transfer of GRP that generate royalty income and which effectively assist in that country's development process. Therefore, and as was stated in relation to interest, exemption at source would not be the rule for all cases.

This proposal differentiates between royalty income that derives from non-beneficial GRP for the source / developing country's economy (or royalty income that derives from taxabusive transactions), and royalty income that derives from beneficial GRP for the source / developing country's economy. Thus, considering that royalty payments are a deductible expense at the payer level per se, and given that according to this proposal there will be no taxation at source - thereby leaving exclusive taxing rights only to the residence country / country where the GRP are owned - it follows that the success of this proposal is contingent on the avoidance of granting beneficial tax treatment to royalty income that derives from GRP that do not effectively assist in the development process of the source country or to royalty income that derives from tax-abusive transactions.

Source taxation will be applied to royalty income that derives from GRP not being used in business activities in the borrower / source / developing country, or royalty income that derives from tax-abusive transactions. By reinstalling a withholding tax at source, the system will ensure real incentives for transferring beneficial GRP, i.e. GRP that effectively enter the source / developing country's economy with no tax-abusive conditions and, therefore, contribute to the development process of that country. This measure does not prevent the promulgation of additional measures in domestic legislation that relate to restrictions on the deductibility of royalties at source.

The transition from the primary to the secondary rule will be the consequence of the application by the source / developing country of an economic-substantive test, i.e. the impact 
of the GRP in the economy of the source country; and of an arm's length test, i.e. to determine if the related transfer of GRP are agreed and fulfilled on similar terms to those that would be entered into by independent parties (so as to avoid mispricing).

By renouncing this right, this proposal expects that subscribing to a DTC between a developing and a developed country will effectively encourage the owners of royaltygenerating GRP to license those GPR to residents of developing countries. As was stated regarding interest income, this research does not share the view of considering the approach of exempting royalty income taxation at source and taxing royalty income at the residence country as an approach more beneficial to the resident country than to the source country. DTCs must naturally be beneficial to both signatory countries. While the source / developing country will benefit from the positive economic impact of the free circulation of GRP, e.g. technology, from developed countries, i.e. technology to improve local businesses, and as a consequence, higher employment and more development accompanied with revenue at source derived from VAT or the taxation of business profits, the resident country must also achieve certain benefits. This would similarly achieve what was achieved in relation to dividends by removing barriers to the repatriation of benefits, and in relation to interest by granting exclusive taxing rights to resident countries. This leave countries of residence in a better position than the position that they currently face under the current UN MTC rules. As was also stated in the context of interest, the fact that such exclusivity may potentially mean more revenue for resident countries compared to the revenue expectations under the current UN MTC criteria, this constitutes a benefit for the resident / developed country as a result of signing a DTC with a developing country.

\subsection{TESTS}

\subsubsection{ECONOMIC-SUBSTANTIVE TEST}

As was stated in the analysis of dividends and interest, namely that it is impossible to analytically separate the equity of the host company from the underlying business activities of the host company, and that it is also impossible to decouple debt capital from such an activity, it follows in the case of royalties that is impossible to analytically separate the GRP 
that generate royalty income from the underlying business activities of the host company. The GRP that are used by the host company - whose rights derive from a licence contract are part of the assets of the host company and they are used in order to generate business income. The UN MTC must include a test that is able to determine the real impact of the GRP that are transferred to the host company - GRP provided to the host company by a foreign unrelated / related party - on the economy of the host country.

The aim of this economic-substantive test is to differentiate between beneficial and nonbeneficial foreign intangibles for countries that are undergoing a process of development, i.e. intangibles / technology as part of the source country's development process. It is necessary, therefore, to determine the economic sector in which the intangibles are being used in order to determine if those intangibles are indeed having a positive effect on the economy of the source country.

Such a test can only be properly developed by economists and the test would naturally depend on the characteristics of each host / developing country. As was discussed in relation to equity / dividends and debt / interest, it is impossible to define a concept of beneficial or nonbeneficial GRP applicable to the economies of all developing countries. Even though each economy has different needs, the concept of beneficial GRP should not be limited to the main business sector of the country. All productive sectors must be considered.

With regard to the definition of beneficial and non-beneficial GRP, they will be left undefined so that they can be decided by each country in accordance with the characteristics of their economies. The idea of the test is to promote access to foreign GRP, e.g. technology, in order to promote those business sectors which have a positive effect on the economy of the source country and, consequently, to directly or indirectly assist in the host country's development. In order to achieve this, it will be essential to ascertain the underlying business activities of the licensor company in the source country.

By differentiating between beneficial and non-beneficial royalty-generating GRP, the test will help to determine, from a tax perspective, to which licenses the DTC will grant more 
favourable tax conditions. Thus, if the foreign GRP is considered by the host source country as an asset that is used in the generation of productive activities within national borders, the source country will exempt the foreign owner from tax at source by eliminating the withholding tax. On the other hand, the source country will tax the royalty income that arises from GRP with a withholding tax in relation to those GRP considered by the host country to be non-beneficial.

The elimination of the first tier of taxation does not mean that the effective tax rate of the foreign investor will be lower than the effective tax rate in a scenario in which it is taxed on royalty income not only by the residence country, but also by the host country. In this latter scenario, royalties will still only be economically taxed once, but instead of being shared between the residence country and the source country, the taxing rights will be exclusively afforded to the residence country. As in the case of interest income, the most positive direct effect of this measure will be the reduction of costs for licensor residents in developing countries with the elimination of the grossing-up practice, i.e. the elimination of the biggest commercial barrier regarding access to foreign GRP that are capable of generating royalty income. The ultimate goal is to ensure that the foreign owners of GRP that generate royalty income are able to compete in the licensor / source country without having to incur higher associated costs. As was also stated in relation to interest, the "gross up" practice cannot be considered as a solution here. While the administrative barrier for the foreign investor is eliminated, at the same time an important commercial tax barrier is imposed, i.e. the burden of the withholding tax is added as an additional cost to the licence contract.

Modern DTCs, instead of facilitating the access to foreign GRP that could be exploited by domestic business, have only focused on the amount of taxing rights that are to be allocated to each contracting state. As regards dividends and interest, the exemption of royalties at source in DTCs between developing and developed countries is considered, according to the more traditional way of thinking, contrary to the legitimate rights of developing countries.

As stated in the chapters that discussed dividends and interest, the incorporation of a test is a means to go one step further than what is usually prescribed under a DTC. For the author, 
the relevance of the impact of the resources in the source / developing country is crucial for determining which GRP licences must be treated more favourably from a tax perspective in order to achieve: (1) access to foreign GRP for business carried out in developing countries and (2) incentives for foreign investors that are resident in developed countries to agree to transfer their GRP to businesses that are located in developing countries.

\subsubsection{ARM'S LENGTH TEST}

As in the case of abusive debt financing structures, the risk of base erosion as a result of an abusive royalty agreement requires the economic-substantive test to be complemented with an arm's length test. The purpose of this is to avoid mispricing by determining if related licence agreements are agreed on similar terms to those that would typically be entered into by independent parties. The royalties deduction at source will erode the tax base of the source country if the terms of the royalty agreement have not been agreed in similar terms as those that would be agreed between independent parties in a comparable transaction. As in the case of interest, since the ability to grant the right to deduct expenses for royalties at source is a matter for domestic law to determine, this proposal will deny the beneficial tax treatment granted in the DTC to the amount of royalties that exceeds those parameters. As was stated when the sanction was a result of royalty income arising from non-beneficial GRP, this measure does not prevent domestic law from imposing additional measures in relation to restrictions on the deductibility of royalty expenses at source.

In addition to the problem described in the case of interest, i.e. the likelihood that it will be successfully applied by developing countries with low tax administrative capacities (fully applicable to the case of royalties), in the case of royalties it is necessary to aggregate the problem of the determination of the proper compensation that is to be given to the developer / owner / licensor of the GRP. In setting an at arm's length royalty rate, it is important to distinguish, as precisely as possible, what GRP is actually being licensed. Once the GRP is identified, the rights granted to the licensee and their relative value must be determined. The property may be an ordinary GRP, i.e. those granted not only to related but also to unrelated 
parties, or it may be an exclusive GRP, i.e. those that are exclusively granted to related parties. For the former, this proposal considers, as an optimal method for determining an at arm's length royalty fee, the use of comparable uncontrolled GRP made to unrelated parties under which identical GRP have been transferred. Such licences can be identified where the developer / owner / licensor has licensed a third party to use the technology under terms that are identical or similar to those granted to the related party, or where the inter-company licensor has received the technology from a third party. If such licence agreement is identified, adjustments can be made for differences in order to determine an inter-company at arm's length royalty rate. However, for the latter scenario, it is difficult to determine an at arm's length royalty fee that is based on a comparable analysis due to the non-existence of data derived from comparable uncontrolled transactions. This forces the author to propose the use of the profit split method instead of the comparable uncontrolled price method.

Regarding the likelihood of the tax authorities of the developing country being able to successful audit the proposed systems, it is expected, as was also the case for interest, that the experience of developing countries with the application of transfer pricing rules can help in the application of this test at the domestic level.

\subsection{PROPOSAL FOR ROYALTY TAXATION AND THE ELIMINATION OF DOUBLE TAXATION}

As was stated in relation to dividends and interest, limiting the role of DTCs to allocating taxing rights when most domestic legislation already does so, does not seem to be enough. By doing so, developing countries maintain the greatest barrier to the cross-border transfer of GRP that generate royalty income from developed to developing countries, i.e. a withholding tax.

As was argued in relation to interest, those whom advocate improvements to the above scenario by increasing the source taxation of royalty income through a withholding tax, 
relying on the benefit theory by considering the fact that the grantee's country of residence (source country) facilitates the grantor's access to the market and therefore deserves a portion of taxing rights over the income, forget that source countries have already taxed or will tax the business profits that arise from the use of those GRP. The hypothetical revenue problem of source countries in a scenario such as that which is proposed by the author - deduction at source and the elimination of withholding tax - is mitigated, from a revenue perspective, by the fact that easy access to foreign intangibles / technology will increase the business profits of local businesses at source. However, assisting in the process of development is the real benefit that this proposal is expected to engender.

As was previously stated concerning interest, if we consider that the taxation of royalties at source under domestic legislation would be the rule in cases where there is no DTC in force, the limitation of sovereignty regarding royalty taxation that source / developing countries will face by concluding a DTC with a developed country - according the author's proposal - must be economically counterbalanced. The easy and affordable access to foreign GRP (in terms of non-additional cost and administrative burdens) will help in the development process of the source / developing country's economy.

Thus, it can be affirmed that it is necessary to revise the system of royalty taxation that is currently in force under the current UN MTC rules. The fact that DTCs that adhere to the UN MTC have no effect in granting easy and affordable access to foreign GRP from developed to developing countries naturally reinforces this proposal. The UN MTC must include, amongst its aims, easy access to foreign GRP that are capable of generating royalty income for domestic businesses in developing countries with the expectation that this will assist in the country's development.

This work proposes a new article regarding the taxation of royalty income for the UN MTC, respecting a general framework in accordance with the following guidelines:

(1) in order to incentivize the use of the UN MTC as the MTC that is to be followed in DTCs between developing and developed countries, the treatment of royalty income 
must be beneficial to all actors, that is, to the grantor residence country, to the grantee resident / developing country, to the grantor lender, and to the grantee;

(2) that income must only be economically taxed once;

(3) taxing rights in relation to royalties should be allocated in a coherent manner, irrespective of whether they arise in a developing or in a developed country; and

(4) business carried out by the grantee within the borders of the source country and at arm's length conditions of the agreement are the elements that will be considered by the author in order to determine the real impact of the intangibles / technology in the economy of the host country.

As a consequence, the author proposes a modification to Article 12 of the UN MTC so as to regulate the taxation of income from royalties in DTCs between developed and developing countries. This amendment would read as follows:

Article 12

ROYALTIES

1. Royalties derived from the licensee beneficial goods, rights, or properties arising in a Contracting State and which are ultimately owned by a resident of the other Contracting State shall be taxable only in that other Contracting State.

2. However, royalties may also be taxed in both Contracting States when they derive from the licensee of non-beneficial goods, rights, or properties, or if by reason of a special relationship between the licensor and the licensee or between both of them and some other person, the amount of the royalty, having regard to the license of goods, rights, or properties for which it is paid, exceeds the amount which would have been agreed upon by the licensee and the licensor in the absence of such relationship. In this last situation, paragraph 1 shall apply only to the last-mentioned amount. 
3. The term "royalties" as used in this Article means payments of any kind received as consideration for the use of, or the right to use, any copyright of literary, artistic or scientific work including cinematograph films, any patent, trade mark, design or model, plan, secret formula or process, or for information concerning industrial, commercial or scientific experience.

4. The provisions of paragraphs 1 and 2 shall not apply if the beneficial owner of the royalties, being a resident of a Contracting State, carries on business in the other Contracting State in which the royalties arise, through a permanent establishment situated therein, or performs in that other Contracting State independent personal services from a fixed base situated therein, and the right or property in respect of which the royalties are paid is effectively connected with (a) such permanent establishment or fixed base, or with (b) business activities referred to in (c) of paragraph 1 of Article 7. In such cases the provisions of Article 7 or Article 14, as the case may be, shall apply.

5. Royalties shall be deemed to arise in a Contracting State when the payer is a resident of that Contracting State. Where, however, the person paying the royalties, whether he is a resident of a Contracting State or not, has in a Contracting State a permanent establishment or a fixed base in connection with which the liability to pay the royalties was incurred, and such royalties are borne by such permanent establishment or fixed base, then such royalties shall be deemed to arise in the Contracting State in which the permanent establishment or fixed base is situated.

6. The terms "beneficial" or "non- beneficial goods, rights, or properties" as used in this Article can be defined as follows: (a) Beneficial goods, rights, or properties: [the definition will be defined, according to the economic reality, by each developing country that subscribes to this Model]; (b) Non-beneficial goods, rights, or properties: [the definition will be defined, according to their economic reality, by each developing country that subscribes to this Model]. The definitions should be based on an economic-substantive test and on an arm's length test. 


\subsection{RATIONALE OF THE PROPOSAL}

The main objective of this proposal is to grant, through the UN MTC, more beneficial tax conditions to the owners of GRP that are capable of generating royalty income in developed countries than the conditions that are normally granted by domestic legislation to these owners when they agree to license these GRP to residents in developing countries. The proposal is based on the assumption that developing countries will be willing to relinquish taxing rights over royalty payments if the outcome of that decision is a positive increase of beneficial foreign GRP that will help in the developing countries' development process.

As was also stated regarding interest, with regard to royalties, the current UN MTC approach requires developing countries to partially relinquish their rights without obtaining positive results, such as easy and convenient access to license foreign GPR. That outcome is usually also achieved by domestic laws without requiring a substantial limitation of taxing rights over royalty income by the host / developing country. The domestic law approach to developing countries vis-à-vis cross-border royalties' taxation normally tends, as MTCs do, to reduce the withholding tax.

The aim of this proposal is to reduce the three tax events of cross-border royalty taxation, i.e. a deduction in the hands of the grantee, source and residence taxation in the hands of the grantor, to only two tax events, i.e. a deduction in the hands of the grantee and residence taxation in the hands of the grantor. By doing so, it will be possible for the grantor to be treated equally than would ordinarily be the case for domestic licences. The proposal achieves not only a level playing field, but also the elimination of the withholding tax barrier, and therefore, the costly "gross up" phenomenon.

Finally, the proposal eschews base erosion by negating the beneficial treatment to royalties agreed in tax abusive terms. 
As was stated regarding dividends and interest, this proposal modifies one of the traditional principles of MTCs. The allocation of taxing rights is no longer the direct result of the analysis of the primary economic activity analysis. The primary economic activity analysis serves as a tool for developing countries to determine what they have and what they will lose or gain by signing a DTC that is based on this new UN MTC approach.

Regarding royalty income, the result of the primary economic activity analysis carried out by the author was that, despite the strong logic of the position that the origin of the royalties is always in the country of residence, because that is the country where the owner invested time and resources in developing or acquiring the intangible, it is also possible to find substantive arguments that support the view that the origin of royalty income is in the source country, e.g. the conditions provided by the source country to exploit the intangible.

Lastly, instead of sharing taxing rights, the proposal calls for the renunciation of those preliminary taxing rights by source / developing countries with the aim of achieving benefits for all actors.

\section{PART VII. CONCLUSION}

Taxing rights are of paramount concern for developing countries when they are negotiating a DTC with developed countries. Indeed, and according to several if not all UN Member States, the inequitable distribution of income between source and residence countries needs to be recalibrated in favour of source countries. As a consequence, one of the main issues in the work of the UN on cross-border taxation focuses on how to increase source country taxation. ${ }^{594}$ If the goal of developing countries is to increase their taxing rights, then it cannot be concluded that DTCs are a suitable solution for them. It is indeed easier and less expensive to avoid signing DTCs with developed countries, and to leave the determination of the level of rights to tax and the responsibility of avoiding double taxation to domestic legislation.

\footnotetext{
594 See for instance the reference to the works of the Eighth Session of the UN Committee of Experts in Tax Matters, 2016.
} 
The renunciation of taxing rights regarding passive investment income, due to the application of a DTC between a developing and a developed country under the current tax framework, has not been the direct consequence of thorough economic analysis. It does not incentivize trade and investment, and therefore, it does not help in the development process of the host country. In order to decide whether developing countries should subscribe to DTCs with developed countries, it is necessary to determine the economic impact of doing so in the developing country. By doing this, it is then possible to determine whether or not it is necessary for developing counties to agree to a DTC with a developed country.

The author revised the work regarding the role of international taxation on the economic progress towards development. Even though international organizations, such as UNCTAD and the OECD, share the goal of positively affecting the economic progress of developing countries through international tax rules, the author's disagreement with their methods has being stated throughout this research. One of the most pertinent conclusions that arises from this research, and which is not in accordance with most contemporary international tax discussions, is that the better way to achieve the real protection of the tax base of developing countries is through the renunciation to tax in DTCs with developed countries, when the outcome of the DTC is an increase in trade and investment. The certainty and (supposed) equality of treatment granted by DTCs in fact must be ancillary to the main goal. Both effects are useless if there is no concomitant increase in trade and investment.

It has been demonstrated how the domestic tax measures of developing countries include, as the basis of their rationale, the idea of increasing trade and investment as a direct or indirect goal. With that said, the author has highlighted the lack of any reference to that goal, especially regarding the treatment of passive investment income in DTCs that have been signed between developing and developed countries.

This research has addressed the analysis of the economic allegiance and benefit theory, and has stated their influence on the current state of the art. George Schanz developed the economic allegiance theory in 1892, stating that the economic link between the income and 
the country could be based on mere consumption or on a business / investment criterion. For Schanz, if the consumption criterion is chosen, then it is the residence country that should enjoy the taxing rights. By way of contrast, if the business or investment criteria are used, then it is the source / host country that should enjoy the taxing rights. The author agrees with Schanz's theory, but states that the economic allegiance must be complemented in the case of DTCs between developing and developed countries, and regarding passive investment income, with the following minimum expectations: (1) an increase in foreign investment, (2) access to useful foreign debt capital, and (3) access to useful / necessary technology. The combination of the above derives from the following premise: "In the design of an MTC to be used to subscribe to DTCs between developing and developed countries, the treatment of passive investment income must consider the economic impact of the investment / transaction in the host / source country. Therefore, if there is a proven and useful economic impact in the host / source country, this country must grant beneficial tax treatment to the foreign investor".

The historical origin of the problem is clear. Notwithstanding the recommendation that was made in 1923 by the LN group of economists "exemption of income going abroad" in the search for the location of the true economic interest of the taxpayer, the influence of the DTCs in force in 1925 naturally determined the LN Technical Expert's approach on the topic. The above was expressly ratified by them when they recognized that the decision was taken for purely practical purposes and it was made with no reference to any economic theory or doctrine. The election of the "classification and assignment of income" as the method to determine the economic allegiance of the taxpayer with the country considering developed countries' interpretation of where does the primary economic activity that gives rise to the income belong, ended as the approach that is still being used by most DTCs today. The above criterion was incorporated into the 1928 Geneva MTC, and it was further recommended by the OECD in its 1963 MTC, and by the UN in its 1980 MTC. The emergence of developing countries' interests in the 1943 Mexico MTC was driven by different factors, which are different to what developing countries face today. The evolution of domestic laws has had a direct effect on the above. All the above was ratified by Peggy Musgrave, who emphasized the untouchable right of home countries to tax worldwide income. 
Regarding CIN or CEN, it was concluded that if the resident country decides to follow the CEN principle, then it will nullify any intention of a host / source country to incentivize foreign investment through tax concessions. On the contrary, if the resident country decides to follow the CIN principle, that approach does not nullify the host / source country's intentions to incentivize foreign investment through tax concessions. On this matter, the author has concluded that the positive evolution of the domestic legislation of developed countries has granted source countries the right to be sovereign regarding their own tax policy. This change in the status quo started in 1981 following the incorporation of the participation exemption system in New Zealand.

Regarding the effects of DTCs on the increase of foreign investment, the analysis started from the assumption that the increase of investments between treaty partners is, at least for developing countries, an economic starting point in the decision as to whether or not to sign a DTC. From the author's perspective, the traditional belief of developing countries that DTCs between a developing and a developed country actually increase foreign investment has not been substantiated with reference to any scientific research. The only indirectly related study on this topic (Chisik and Davies) states that as the asymmetry of foreign investments grows, the scope for cooperation decreases, and negotiated withholding taxes tend to be higher as a result. The above demonstrates the natural, but in the author's opinion wrong, intent of achieving fairness through the increase of source countries' withholding taxes. Just a wrong conventional solution to the problem of the allocation of taxing rights. Eric Neumayer concluded, only applicable to middle-income countries, that countries with more DTCs with major capital-exporting countries benefit from a higher overall FDI and receive more FDI inflows as well as a higher share of inflows. While it is not applicable to the reality of all developing countries, Neumayer's study demonstrates that in the analysis of the economic impact of DTCs between developing and developed countries, it is necessary to differentiate between developing countries. Even more, and which is also a factor considered by the author in this research, he considered that each country has different realities and therefore those differences must be reflected in the negotiation of their own DTCs. 
The author analysed this principle in the proposal not by differentiating according to the level of development of each developing country, but by focusing instead on the real impact of the investment in the host / source / developing country. The most conclusive work on the topic is that carried out by Paul L. Baker. He concluded that DTCs have no effect on foreign investment from developed to less developed countries. He raised a crucial element that has been considered by the author in this research, namely the fact that developed countries unilaterally provide for the relief of double taxation.

This work also addressed, through an historic study of the subject-matter, the undesired influence of the OECD MTC on the UN MTC. The author explored the history of DTCs and sought to answer the question: to which country does the economic activity that gives rise to the income belong? That historic development demonstrates the undeniable influence of the OECD MTC on the UN MTC. As was stated by the author, the failure of the current approach to the taxation of passive investment income in DTCs between developing and developed countries does not come from the wrong answer to the question mentioned above, but from the fact that the UN MTC has not evolved to the point of considering the economic benefits that an agreement as such should bring to the signatory countries, especially to the host / source / developing country.

The MTC of the League of Nations took a combined approach by taking the economic allegiance theory as its economic basis, and using the classification and assignment method chosen by the committee of Technical Experts to then allocate taxing rights. The author raised the evident influence of the nationality of the members of both groups on these approaches. The influence of the UK and the USA were determinative factors on the vision of the Committee of Technical Experts. That influence, combined with the similar levels of economic development among the League of Nations members, and the assumption of reciprocal trade and investments flows between treaty partners were, at least from the author's perspective, the reasons why that approach has been successful for the negotiation of DTCs between developed countries. 
The OECD MTC was developed according to the needs of the 20 OECD members in 1963. The aim was to increase economic interdependence and cooperation amongst the member countries in the post-war period. It was recognized by the Fiscal Committee of the OEEC (1958-1961) that the taxation of dividends, interest and royalties was their most difficult task. They argued that the economic analysis of where the economic activity that gives rise to the income belongs was only one of the various elements involved in the analysis. They opted for a practical solution that was supported by the fact that OEEC countries in those years were on a level playing field in terms of development. The above fixed, for good, the existence of a shared system of taxation - dividends and interest - between the source and the residence country.

In the historical analysis, the author highlighted some of the valuable contributions made by developed countries. As stated in this research, these contributions were probably due to the fact that developed countries were facing similar economic realities at that time. On 19 January 1959, the Italian delegation sent a confidential note to the Fiscal Committee of the OEEC regarding the taxation of dividends. This note proposed a reduction in the rate of tax on dividends at source when the recipient took an active and direct part in the economic life of the source country. Italy supported the idea that dividends derived from a controlled investment were the result of a more active than passive activity. They voted for analysis of dividends on a case-by-case basis and then, on that basis, to properly allocate taxing rights. The formal proposal was to reduce source taxation when the recipients were not participating, in an active way, to the country's economic life / passive investment. That approach, integrated with the source country's development, could end with the undesired effect of shifting tax revenue from developing to developed countries.

On 2 December 1958, a note from Belgium was circulated amongst the Fiscal Committee of the OEEC regarding their criteria on the principles that should be adopted to govern the allocation of rights on royalty income. Notwithstanding that the outcome of their proposal was different from that which the author is currently proposing, Belgium nevertheless contributed to the discussion on the source of royalty income. Belgium considered that there was no justification for giving the exclusive right to tax royalties to the country of residence 
of the grantor. Belgium supported the view that it seemed to be correct to allow the country in which the rights are used to levy a reasonable tax on the net income obtained by the foreign grantor by virtue of such use.

Despite these inspiring interventions, the reality demonstrated that in stark contrast to the great work that the OEEC had done by analysing the nature of the income and then attributing taxing rights to the residence or to the source country by considering the economic benefits of those transactions, the OEEC focused on the different tax systems of the member countries at that time, and made its proposals accordingly.

On the evolution of the OECD MTC, an important change took place in 1992. The author views this change as the best demonstration of how the tax policy behind the UN MTC operates. This influence that the OECD MTC has had on the UN MTC is undeniable. However, as a result of this change, the UN MTC evolved in a way which was evidently guided by the preference of having taxing rights instead of allocating taxing rights according to the nature of the income and thereby privileging the easy flow of investments. In all other aspects regarding the taxation of passive investment income, the UN MTC almost followed the OECD MTC approach in this regard.

The OECD recognizes that the harmful effects of double taxation on cross-border trade and investment are so well known that it is necessary to stress the importance of removing the obstacles that double taxation presents for the development of economic relations between countries. The approximate balance in the reciprocity of investment flows and, therefore, the rights to tax, means that DTCs between two developed countries do not force a non-reciprocal limitation of taxing rights. The OECD achieves this goal by improving market conditions so that they are conducive to increased trade and investment between treaty partners.

The UN decided to add non-reciprocal limitations to tax in the UN MTC and the imposition of higher withholding taxes was their tool for doing so. The above contradicts the recognition made by the ECOSOC in 1967 regarding their conviction that DTCs between developed and developing countries can promote investment flows which are beneficial for the economic 
development of the latter, especially if those DTCs provide favourable tax treatment to such investments on the part of the countries of origin, both by outright tax relief and by measures which would ensure them the full benefit of any tax incentive allowed by the country of investment.

Specific measures such as tax sparing clauses and matching credits were also analysed over the course of this research. It was concluded that they are not constructed in such a way so as to achieve what this current proposal is looking for. These clauses ensure that the tax incentives offered by the host country accrue to the foreign investor and not to the development of the host country. Moreover, they are susceptible to tax abuse and short-term investments. The author stressed the fact that in order to achieve development, there must be more than tax incentives, and tax incentives should only be granted to beneficial investments. In this part of the research, the author arrived at the conclusion that foreign investment must help in the development of developing countries' economy, in other words, that is perfectively possible to have foreign investment that does not contribute to the development of the host / source country's economy, and therefore, development. Elements such as knowledge, experience, culture and various other external elements are much more relevant in this regard than revenue is.

Further to this, and specifically regarding BITs, the legal profile of the author prevented him from entering into the interesting challenge of, in the case of developing and developed countries, merging DTCs and BITs. However, and following an analysis of the doctrine and history of BITs, the author concluded the necessity to unveil the complementary role of DTCs and BITs by including the aims of BITs within the UN MTC.

Regarding the role of withholding taxes in DTCs between developing and developed countries, the author made salient the contradiction of creating double taxation through a DTC by recognizing the right to tax non-residents on their passive investment income at source through a withholding tax. It was confirmed that the main objective of withholding taxes is to avoid tax evasion. The above, as well as the fact that source countries have centred the discussion on raising withholding taxes, is why this mechanism neither achieves a fair 
allocation of taxing rights nor is capable of attracting foreign investment. The fact was also added to the discussion that withholding taxes are applied on a gross basis instead of on a net basis, thereby ensuring the existence double taxation, which is in turn aggravated by the fact that the UN MTC leaves the tax rate of withholding taxes regarding passive investment income open to treaty negotiations. Ultimately, the author analysed the approach of the UN MTC of imposing sanctions on discrimination in Article 24 and creating discrimination in Articles 10, 11 and 12. The above is due to the potential difference on the final tax rate of residents and non-residents, especially when one considers that countries imposing withholding taxes on non-residents do not make refunds based on the tax position of the recipient.

In the analysis of the approach adopted by BRIC countries, it was proven with reference to data, i.e. DTCs subscribed by BRIC countries since 2001, that these countries have negotiated less source taxation. This, however, has not been done with the aim of facilitating trade, but instead by focusing on signing DTCs with developing or less developed countries. In simple terms, they are acting as capital-exporting countries, and therefore, their negotiation behaviour cannot be taken as examples for the purposes of developing countries according to the parameters of this research.

Ultimately, the author worked on the proposals. Considering the research cited, the author concluded that only two works have considered the increase of foreign investments in the host country as an important element of DTCs. That evidenced the necessity of reinforcing the causal relationship between DTCs and the increase in foreign investment. Regarding the international flow of investments from developed to developing countries that has undoubtedly increased in the last 50 years, it was concluded that such increases have not been caused by DTCs. As the worst case scenario, it has shifted taxing rights away from developing to developed countries due to the parallel increase of DTCs between them.

Considering all of the above, the author developed the principles that sustain this research and the resulting proposals. In order to achieve fairness, it was considered that the individual's whole faculty should be taxed and that such faculty should be economically 
taxed only once. Taxing rights should be assigned to one signatory country or divided between the two signatory countries according to the relative link of each country to the corresponding income. By taxing only once, non-discrimination will be guaranteed and so too will the economic obstacle of over-taxation. These principles are similar to those used in the EU market. The paradigm that has to change is the "harmful effect of juridical double taxation". ${ }^{595}$ The new guiding paradigm, at least regarding dividend taxation, must be the "harmful effect of economic double taxation". The proposals must analyse where the primary activity of the income takes place and guarantee that the income will be taxed only once. In order to achieve that aim, an economic-substantive test or, in some cases an alternative presence test, or other such tests, must apply.

Firstly, and regarding the proposal on the taxation of dividends, the proposal achieves the elimination not only of juridical but also of economic double taxation. As a complement to achieve this goal, the author proceeds from the premise that is worthwhile for DTCs between developing and developed countries to differentiate between beneficial and non-beneficial foreign investment, i.e. productive and counterproductive foreign investments for developing countries, instead of differentiating between FDI and FPI. In essence, the author decided to propose the elimination of a withholding tax at the host / source country for both types of equity investments and an exemption or indirect credit at the home / residence country. This approach should be used alongside an exemption for the ultimate beneficial owner in the case of beneficial investments and a deduction from the personal income tax base of an amount proportional to the corporate income tax paid by the distributing entity at source in the case of non-beneficial foreign investments.

The author carried out an analysis of where the primary economic activity of dividends takes place, which allowed the author to determine which country deserves the preliminary rights to tax according to the origin of the income. Once the above was completed, the author included the necessity of whether to partially or completely limit those taxing rights according to whether or not they would promote foreign investment, neutral tax treatment,

\footnotetext{
${ }^{595}$ United Nations, Department of Economic and Social Affairs, Model Double Taxation Convention between Developed and Developing Countries, 2017.Introduction.
} 
legal security, legal certainty and repatriation benefits. The level of limitation on taxing rights will depend on the impact of the investments in the host / source country. To that end, the proposal includes the application of an economic-substantive test, and in some cases, the application of a temporary test. Consequently, it was concluded that if the foreign equity is considered by the host country to be a beneficial investment, then the elimination of economic double taxation by the home / resident country will be ensured by exempting those dividends from tax. On the other hand, if the foreign equity is considered by the host country to be a non-beneficial investment, the elimination of economic double taxation by the home / resident country will be achieved by granting an indirect credit.

The new Article 10 of the UN MTC, which was proposed by the author, is expected to guarantee benefits to all actors; it forces both signatory countries to renounce taxing rights in order to achieve benefits, and it ensures that the income will be taxed only once.

Secondly, and regarding the proposal on the taxation of interest, the proposal also achieves the elimination of juridical double taxation. Interest income does not create economic double taxation. The differences in the treatment of cross-border equity finance and cross-border debt finance are naturals. Dividends and interest are different types of income per se, due to the fact that they derive from different types of financing instruments.

On the issue of hybrid finance, the author has concluded that the UN MTC, the OECD MTC or the BEPS have come up with a suitable solution in this regard. Specifically regarding the BEPS, and in line with the logic of this research, the author concluded that it starts from the assumption that the system governing the international taxation of equity and debt is actually correct. The above can be valid in a scenario between two developed countries, but not in a scenario between a developing and a developed country. All of the above is justified by the fact that the actual system does not incentivize the increase of international borrowing, and therefore, there is no benefit to developing countries after they renounce taxing rights. The right of the borrower to deduct interest payments as expenses must be understand as a measure that is granted by the source country to make it less costly for their residents to access foreign debt. This proposal expects to reduce the tax cost differences for taxpayers 
between cross-border debt and equity. By doing so, the tax arbitrage will be reduced, and consequently, the erosion of the tax base - related debts - will not be an unsolvable problem, like it is today.

As in the case of dividends, the author carried out an analysis of where the primary economic activity of interests takes place, which allowed the author to determine which country deserves the preliminary rights to tax according to the origin of the income. In addition, and as was also done regarding dividends, the necessity of partially or completely limiting those taxing rights according to the aim of promoting foreign investment, neutral tax treatment, legal security, legal certainty and repatriation benefits were taken into account.

The level of limitation on taxing rights will depend on the impact of the debt in the host / source country. The author concluded that beneficial tax treatment will not be granted to interest that arises from debt capital that does not effectively help in the development process of the borrower / source / developing country. Consequently, the conclusion was that if the foreign debt is considered to be a beneficial debt, the elimination of juridical double taxation by the host / source country will be ensured by exempting interest from tax - elimination of withholding tax. On the other hand, if the foreign debt is considered to be a non-beneficial debt, source taxation will be re-installed. What was achieved regarding dividends by removing barriers on the repatriation of benefits, will be achieved regarding interest by granting exclusive taxing rights to resident countries. The potential increase of revenue for resident countries is one of the benefits of signing a DTC with a developing country. Lastly, and regarding the revenue balance at source, the author concluded that this is achieved through the taxation of business profits at source, and therefore, applying a withholding tax over interest income at source cannot be justified as being necessary to achieving that balance.

The new Article 11 of the UN MTC, which was proposed by the author, is expected to guarantee benefits to all actors; it forces the source country to renounce taxing rights in order to achieve benefits, and it ensures that the income will be taxed only once. 
Thirdly, and regarding the proposal on the taxation of royalties, the proposal achieves the elimination of juridical double taxation. Royalty income does not, therefore, create economic double taxation.

The analysis carried out in this work covered the problem of the definition of royalties in the UN MTC and the OECD MTC. The author concluded that since the UN MTC and the OECD MTC allocate the taxing rights on royalty income differently, the hypothetical elimination of "the use of, or the right to use, industrial, commercial or scientific equipment" from the UN MTC would result in a reduction of the right to tax for source countries. According to the same line of reasoning, the author explained why this was not a real concern for representatives of developed countries when the phrase was first removed from the OECD MTC. For the author, the determinant factor is the fact that since the likelihood that the performance of these types of services could be considered as a permanent establishment was low, the residence country normally kept fully taxing rights. The above increases taxing rights to countries exporting technology / intangibles. In other words, the level of taxing rights of source countries in a DTC based on the OECD MTC remained the same after the removal of those services from the definition of royalties. However, if the same phrase were to be removed from the UN MTC definition, the source country would in fact lose taxing rights.

Since the proposals contained in this research on royalties, as in the case of dividends and interest income, are based on the logic that royalty income should be taxed only once, and as in the case of interest income, it should be the source country that renounces taxing rights, the author expressed his view on the OECD MTC approach to royalty income taxation, i.e. exclusive taxing rights should be granted to the country of residence. The historic truth demonstrates that the ultimate goal of the DTCs concluded immediately after World War II was to achieve the development of economies in Europe. For the author, that same logic applies to the proposals contained in this research.

As in the case of dividends and interest, the author carried out an analysis of where the primary economic activity of royalties takes place, which allowed the author to determine 
which country deserved the preliminary rights to tax according to the origin of the income. In addition, and as was also done regarding dividends and interest, the necessity of partially or completely limiting those taxing rights according to the parameters of promotion of foreign investment, neutral tax treatment, legal security, legal certainty and repatriation benefits was included in the assessment.

The level of the limitation on taxing rights will depend on the impact of the intangible in the host / source country. It was stated that beneficial tax treatment should not be granted to royalty income that does not arise from intangibles that effectively help in the development process of the borrower / source / developing country. Consequently, the author concluded that if the intangible is considered to be a beneficial intangible, then the elimination of juridical double taxation by the host / source country would be ensured by exempting royalty from tax - thus elimination of withholding tax. On the other hand, if the intangible is considered to be a non-beneficial intangible, source taxation will be re-instated. The same rule was proposed for the situation in which the beneficial owner of the royalties does not reside in the other contracting state, and regarding royalties that derive from beneficial or invest in non-beneficial intangibles, where there is an intentional erosion of the tax base of the source country.

What was achieved regarding dividends by removing barriers to the repatriation of benefits will be achieved, similar to the case for interest, by granting exclusive taxing rights to resident countries. The potential increase of revenue for resident countries is one of the benefits of signing a DTC with a developing country. Lastly, and regarding the revenue balance at source, this research has concluded that this is achieved through the taxation of business profits at source, and therefore, applying a withholding tax over royalty income at source, as was stated regarding interest income, cannot be justified as being necessary to achieving that balance.

The new Article 12 of the UN MTC, which was proposed by the author, is expected to guarantee benefits to all actors; it forces the source country to refrain from allocating taxing 
rights in order to achieve certain benefits, and it ensures that the income will be taxed only once. 


\section{BIBLIOGRAPHY}

\section{ARTiCles AND REPORTS}

Alfaro, Laura. Foreign Direct Investment and Growth: Does Sector Matter?, Boston, Harvard Business School, 2003.

Arnolds, Brian J. An introduction to tax treaties, United Nations, 2015.

Avery Jones, John. Avoiding Double Taxation: Credit vs Exemption, The Origins, Bulletin for International Taxation, $\mathrm{Vol} 66, \mathrm{~N}^{\circ} 2,2012$.

Avi-Yonah, Reuven S. Double Tax Treaties: An Introduction, University of Michigan Law School, 2007.

Avi-Yonah, Reuven S. The structure of international taxation: A proposal for simplification, Texas Law Review, Vol 74, 1996.

Azzi, John. Policy Considerations in the Taxation of Foreign-Source Income. Bulletin for International Fiscal Documentation, Vol 47, 1993.

Baas, Nicolas. Prevost Car Inc. v. The Queen, Moodys Tax, 2009.

Baggerman-Noudari, Khadija; and Offermanns, René. Foreign Direct Investment in Developing Countries: Some Tax Considerations and Other Related Legal Matters. IBFD, Bulletin for International Taxation, 2016.

Baker, Paul L. An Analysis of Double Taxation Treaties and their Effect on Foreign Direct Investment. International Journal of the Economics of Business, Vol 21, 2014. 
Barker, William B. An International Tax System for Emerging Economies, Tax Sparing, and Development: It Is All about Source. University of Pennsylvania Journal of International Law, Vol 29, 2007.

Barnes, Peter. Limiting Interest Deductions and Other Financial Payments, United Nations, 2014.

Barthel, Fabian; Busse, Matthias; and Neumayer, Eric. The Impact of Double Taxation Treaties on Foreign Direct Investment: Evidence from large dyadic panel data, Contemporary Economic Policy, Vol 28, 2010.

Benshalom, Ilan. The Quest to Tax Interest Income: Stages in the Development of International Taxation, Virginia Tax Review, Vol 27, 2008.

Beveridge, Fiona. The treatment and taxation of foreign investment under international law: Towards International Disciplines. Manchester University Press, 2000.

Bird, Richard M.; and de Jantscher, Casanegra. Improving Tax Administrations in Developing Countries. International Monetary Fund, 1992.

Bischel, John E. Basic approaches to treaty negotiation, United Nations, 2014.

Blanluet, Gauthier; and Durand, Philippe J. General Report in Key practical issues to eliminate double taxation of business income. Cahiers de droit fiscal international 96b International Fiscal Association, 2011.

Bloningen, Bruce A. A Review of the Empirical Literature on FDI Determinants. Atlantic Economic Journal, Vol 33, 2005. 
Blonigen Bruce A.; and Davies, Ronald B. Do Bilateral Tax Treaties Promote Foreign Direct Investment? Working Paper 8834, National Bureau of Economic Research, 2002.

Braun, Julia; and Zagler, Martin. An Economic Perspective on Double Tax Treaties with(in) Developing Countries. World Tax Journal, 2014.

Braun, Julia; and Zagler, Martin. The true art of the tax deal: Evidence on aid flows and bilateral double tax agreements. World Economy, Wiley, Vol 41, 2018.

Brooks, Kim. Using the Tax System to Promote Investment in Low-Income Countries: An illustration of good intentions, bad results in Globalization and the Impact of Tax on International Investments: A Symposium in Honour of the Memory of the Late Alex Easson, Queen's University, 2008.

Brooks, Kim. Tax Treaty Treatment of Royalty Payments from Low-Income Countries: A Comparison of Canada and Australia's Policies. EJournal of Tax Research, Vol 5, No. 2, 2007.

Buitrago Diaz, Esperanza. Políticas Públicas y Tributación Internacional, Foro Economía del Derecho de Autor, 2010.

Buitrago Diaz, Esperanza. Propiedad Intelectual y Desarrollo tras el Acuerdo sobre los ADPIC, Revista EPI, 2009.

Buitrago Diaz, Esperanza. Propiedad intelectual en la mira de la política comercial y tributaria. Lecciones de Derecho Tributario Inspiradas por un Maestro (en homenaje a don Eusebio González García), 2010.

Buitrago Diaz, Esperanza. The impact of international direct taxation on the economic exploitation of copyrights, SERCI, 2010. 
Byrne, Peter. Los Convenios Internacionales para evitar la doble tributación. Política Fiscal, 1999.

Carrol, Mitchell B. Allocation of Business Income: The Draft Convention of the League of Nations. Columbia Law Review, Vol 34, 1934.

Carrol, Mitchell B. Benefits for American Investors and Enterprises Abroad: Part 1. International Tax Law, Vol 2, 1968

Chaudhuri, Sarbajit; and Mukhopadhyay, Ujjaini. Foreign Direct Investment in Developing Countries. A Theoretical Evaluation, India, Springer 2014.

Chisik, Richard; and Davies, Ronald B. Asymmetric FDI and tax-treaty bargaining: theory and evidence, Journal of Public Economics, Vol 88, 2004.

Christians, Allison. Tax Treaties for Investment and Aid to Sub-Saharan Africa: A Case Study in The Effect of Treaties on Foreign Direct Investment: Bilateral Investment Treaties, Double Taxation Treaties, and Investment Flows. Edited by Karl P. Sauvant and Lisa E. Sachs. Oxford University Press, 2009.

Coates, W. H. Double Taxation and Tax Evasion. Journal of the Royal Statistical Society, Vol 88, 1925.

Cockfield, Arthur J. Reforming the Permanent Establishment Principle through a Quantitative Economic Presence Test, Canadian Business Law Journal, Vol 38, 2003.

Dagam, Tsilly. The tax treaties myth. New York University Journal of International Law and Politics, Vol 32, 2000. 
Daurer, Veronica; and Krever, Richard. Choosing between the UN and the OECD Tax Policy Models: an African Case Study. European University Institute, Florence: Robert Schuman Centre for Advanced Studies. Working Paper RSCAS 2012/60.

Daurer, Veronika. Tax Treaties and Developing Countries. Intertax, Vol 42, 2014;

Davies, Ronald B. Tax Treaties and Foreign Direct Investment: Potential versus Performance. International Tax and Public Finance. Vol. 11, 2004.

Davies, Ronald B. Tax Treaties, Renegotiations, and Foreign Direct Investment. Economic Analysis and Policy, Vol 33, 2003.

De Gregorio, José; Edwards, Sebastián; and Valdés, Rodrigo. Controls on capital inflows: do they work?, 2000.

de Mooij, Ruud A. Tax Biases to Debt Finance: Assessing the Problem, Finding Solutions, IMF Staff Discussion Note, 2011.

Desai, Mihir A.; and Hines, James R. Jr. Evaluating International Tax Reform, National Tax Journal, Vol 56, 2003.

Dornelles F, The Relevance of Double Taxation Treaties for Developing Countries. Bulletin for International Taxation, Vol 43, 1989.

Drabkin, Erik; Serwin, Kenneth; and Tyson, Laura D. Implications of a Switch to a Territorial Tax System in the United States: A Critical Comparison to the Current System, BRG Berkeley Research Group, 2014.

du Toit, C.P. Beneficial Ownership of Royalties in Bilateral Tax Treaties. Faculty of Law University of Amsterdam, 1999. 
Easson, Alex. Do We Still Need Tax Treaties, IBFD, Bulletin for International Taxation, Vol $54 \mathrm{~N}^{\circ} 12,2000$.

Ernst, Markus. Toward a Level Playing Field for Thin Capitalization: German and US Approaches, Tax Notes International, Vol 43, 2006.

Evans, Kimberly. Foreign Portfolio and Direct Investment. Complementary, Differences, and Integration. OECD, Global Forum on International Investment. Attracting Foreign Direct Investment for Development, Shanghai, 2002.

EY Global Tax Alert, German Federal Ministry of Finance reacts to CJEU decision regarding German anti-treaty shopping rule, 2018.

Farrel, Jennifer E. The Interface of International Trade Law and Taxation. IBFD, Doctoral Series 26, 2013.

Fatica, Serena; Hemmelgarn, Thomas; and Nicodème, Gaëtan. The Debt-Equity Tax Bias: consequences and solutions, Taxation Papers, Working paper $\mathrm{N}^{\circ} 33$, European Commission, 2012.

Feldman, Robert A.; and Kumar, Manmohan S. Emerging Equity Markets: Growth, Benefits, and Policy Concerns. The World Bank Research Observer, Vol 10, 1995.

Fleming, J. Clifton Jr; and Peroni, Robert J. Exploring the Contours of a Proposed U.S. Exemption (Territorial) Tax System. Tax Notes, Vol 109, 2005.

García Heredia, Alejandro. The definition of Royalties in International Tax Law: The copyright, industrial and know-how, Spain, University of Oviedo, EATTA Prizewinner, 2007. 
Goldman Sachs. Building Better Global Economic BRICs. Global Economics Paper 66, 2001.

Graetz, Michael. Taxing international income: inadequate principles, outdated concepts, and unsatisfactory policies. Tax Law Review, Vol 54, 2001.

Graetz, Michael J.; and O'Hear, Michael M. The 'Original Intent' of U.S. International Taxation. Duke Law Journal, Vol 46, 1997.

Greig, John A. Aspects of Interest Withholding Tax. Revenue Law Journal, Vol 3, 1993.

Haugland, Kristian R. The Concept of Tax Sparing: A General Analysis, and an Analysis and Assessment of the Various Features of Tax Sparing Provisions, Master's Thesis headed by Professor Frederik Zimmer, University of Oslo, 2013.

Hernández Gómez, Mónica Inés. The BRICs: Tax Treaty Policy Regarding Dividends. IBFD, Bulletin for International Taxation, Vol 66, 2012.

Hines, James R. Jr. Tax Sparing and Direct Investment in Developing Countries in International Taxation and Multinational Activity, University of Chicago Press, 2000.

Hines, James R. Jr. What is benefit taxation?. Journal of Public Economics, Vol 75, 2000.

Huizinga, Harry. International Interest Withholding Taxation: Prospects for a Common European Policy, International Tax and Public Finance, Vol 1, 1994.

Huizinga, Harry; Laeven, Luc; and Nicodème, Gaëtan. Capital Structure and International Debt Shifting, Journal of Financial Economics, Vol 88, 2007.

Irish, Charles R. International Double Taxation Agreements and Income Taxation. The International and Comparative Law Quarterly, Vol 23, 1974. 
Kane, Mitchell. Considering 'Reconsidering the Taxation of Foreign Income'. Tax Law Review, Vol 62, 2009.

Kaserer, Christoph. Restricting Interest Deductions in Corporate Tax Systems: Its Impact on Investment Decisions and Capital Markets, Technische Universität München, Center for Entrepreneurial and Financial Studies, 2008.

Kaufman, Nancy H. Fairness and the taxation of international income. Law and Policy International Business, Vol 29, 1998

Knoll, Michael. Reconsidering International Tax Neutrality. Tax Law Review, Vol 64, 2011.

Kofler, Georg. Indirect Credit versus Exemption: Double Taxation Relief for Intercompany Dividends. IBFD, Bulletin for International Taxation, Vol 66, №2, 2012.

Kosters, Bart. The United Nations Model Tax Convention and its Recent Developments. IBFD, Asia-Pacific Tax Bulletin, Vol 10, 2004.

Krauss, D. T. The Benefit Theory of Taxation. Tennessee Law Review, Vol 11, 1932.

Krishna, Vern. Treaty Shopping and the Concept of Beneficial Ownership in Double Tax Treaties. Canadian Current Tax, Vol 19, 2009.

Lang, Michael; and Owens, Jeffrey. The role of tax treaties in facilitating development and protecting the tax base. WU International Taxation Research, Paper Series No. 2014-03

Larking, Barry; and van der Jagt, Robert. The case for withholding tax on a net basis within the EU. International Tax Review, Vol 21, 2010. 
Larkins, Ernest. Double Tax Relieffor Foreign Income: A Comparative Study of Advanced Economies. ATAX Discussion Paper Series 4, 2001.

Lejour, Arjan. The foreign investment effects of tax treaties. CPB Netherlands Bureau for Economic Policy Analysis, 2014.

Lennard, Michael. The Purpose and Current Status of the United Nations Tax Work. IBFD, Asia-Pacific Tax Bulletin, Vol 14, 2008.

Lennard, Michael. The UN Model Tax Convention as compared with the OECD Model Tax Convention - Current points of difference and recent developments. IBFD, Asia-Pacific Tax Bulletin, Vol 49, 2009.

Levine, Ross; and Zervos, Sara. Stock Markets, Banks, and Economy Growth. The American Economic Review, Vol 88, 1998.

Li, Jinyan. Globalization and the Impact of Tax on International Investments: A Symposium in Honour of the Memory of the Late Alex Easson. Queen's University, 2008.

Ligthart, Jenny; Vlachaki, Mina; and Voget, Johannes. The Determinants of Double Tax Treaty Formation. Tilburg University, 2011.

Lüdicke, Jurgen. Germany: Exemption and Tax Credit In German Tax Treaties - Policy and Reality. Bulletin for International Taxation, Vol 64, 2010.

Maisto, Guglielmo. Residence of Individuals under Tax Treaties and EC Law, IBFD, 2010.

Masui, Yoshihiro. Taxation of Foreign Subsidiaries: Japan's Tax Reform 2009/2010. IBFD, Bulletin for International Taxation, Vol 64, N 4, 2010. 
McGauran, Katrin. Should the Netherlands Sign Tax Treaties with Developing Countries? Amsterdam, 2013.

McIntyre, Michael J. Developing Countries and International Cooperation on Income Tax Matters: An Historical Review, 2015.

Michielse, Geerten M.M. Treaty Aspects of Thin Capitalization, IBFD, Bulletin 57, No. 11, 1997.

Mintz, Jack M. How Tax Barriers Stifle North American Capital-Market Efficiency -- and How Their Removal Would Deepen NAFTA Integration, 2003

Moreno Uribe, Heriberto; and Arce Vargas, Jorge. Importancia de establecer un acuerdo para evitar la Doble Tributación México-España. Mesa Estrategia Empresarial. V Encuentro estatal de investigación en las ciencias económico administrativas y primer encuentro de integración y articulación de la investigación. Universidad Autonoma del Estado de Hidalgo, 2010 .

Mosia, Jonas. When is Foreign Direct Investment Beneficial to a Country and When Is It Not? The Case of South Africa. SAIIA Policy Briefing, Vol 44, 2012.

Musgrave, Peggy B. Consumption Tax Proposals in an International Setting. Tax Law Review, Vol 54, 2000-2001.

Musgrave, Peggy B. United States taxation of foreign investment income: issues and arguments. Cambridge: International Tax Program, Law School of Harvard, 1969.

Musgrave, Richard A. Fiscal Systems, New Haven: Yale University Press, 1969. 
Musgrave, Richard A.; and Musgrave, Peggy B. Inter-nation Equity, in Modern Fiscal Issues: Essays in Honor of Carl S. Shoup, edited by Richard Bird and John Head, Toronto, 1972.

Neil, Stephens. A Progressive Analysis of the Efficiencies of Capital Import Neutrality. Law and Policy in International Business, 1998.

Neumayer, Eric. Do double taxation treaties increase foreign direct investment to developing countries?. The Journal of Development Studies, Vol 43, 2007.

Pickering, Ariane. Why Negotiate Tax Treaties?. Papers on Selected Topics in Negotiation of Tax Treaties for Developing Countries, United Nations, 2013.

Piltz, Detlev J. General Report in International aspects of thin capitalization, Cahiers de droit fiscal international, Vol 81b, International Fiscal Association, 1996.

Pinto, Dale. E-commerce and source-based income taxation. International Bureau for Fiscal Documentation, Doctoral Series Vol 6, 2003.

PWC Report. Evolution of Territorial Tax Systems in the OECD, 2013.

Qureshi, Asif. Tax Treaty Needs of Developing Countries, in UN Draft Model Taxation Convention. IFA Congress Seminar Series 31, Vol. 4, Wolters Kluwer Law, 1979.

Reisen, Helmut; and Soto, Marcelo. Which Types of Capital Inflows Foster DevelopingCountry Growth?. International Finance, Vol 4, 2001.

Rich, Roland Y. The Right to Development as an Emerging Human Right. Virginia Journal of International Law, Vol 23, 1983. 
Richman (then Musgrave), Peggy B. Taxation of Foreign Investment Income - An Economic Analysis. Johns Hopkins Press, 1963.

Rodriguez, Saúl Alberto. La armonización tributaria en América Latina. UNMSM Lima, Vol 5, 1998.

Rosembuj, Tulio. Personal and Economic Allegiance under the Personal Income Tax and the Corporate Tax in Spain. Intertax, Vol 26, 1998.

Sachs, Lisa E; and Sauvant, Karl P. BITs, DTTs, and FDI flows: An Overview in The Effect of Treaties on Foreign Direct Investment: Bilateral Investment Treaties, Double Taxation Treaties and Investment Flows, Oxford University Press, 2009.

Sakuragawa, Masaya; and Watanabe, Yoshitsugu. Foreign Direct Investment and Portfolio Investments in the World, Keio University, 2009.

Salacuse, Jeswald W; and Sullivan, Nicholas P. Do Bits Really Work?: An Evaluation of Bilateral Investment Treaties and Their Grand Bargain. Harvard International Law Journal, Vol 46, 2005.

Sheppard, Lee. Revenge of the Source Countries, part IV: Who Gets the Bill?, Tax Notes International, 2005.

Shaheen, Fadi. International Tax Neutrality: Reconsiderations. Virginia Tax Review, Vol 27, 2007.

Shaheen, Fadi. International Tax Neutrality: Revisited. Tax Law Review, Vol 64, 2011.

Shaviro, Daniel. A Blueprint for Future Tax Reform?: Evaluating Reform Panel's Report, Tax Analysts, 2005. 
Schön, Wolfgang. Tax Competition in Europe. General Report. Max Planck Institute, Munich. IBFD, 2003

Schön, Wolfgang; Bakrozis, Andreas; Becker, Johannes; Beuchert, Tobias A; Boer, Martin; Dwenger, Nadja; Gerten, Andreas; Haag, Maximilian; Heidenbauer, Sabine; Hohmann, Carsten; Jehlin, Alexander; Kopp, Karin E.M; Kornack, Daniel; Lagdali, Nadia; Marguart, Christian; Mueller, Lukas; Castelon, Marta; Osterloh-Konrad, Christine; Paxinou, Natalia;

Porhlhausen, Carlo; Redeker, Philipp; Röder, Eric; and Roesener, Astrid. Debt and Equity in Domestic and International Tax Law - A Comparative Policy Analysis, British Tax Review 2014.

Schön, Wolfgang; Beuchert, Tobias A; Roesener, Astrid; Gerten, Andreas; Haag, Maximilian, Heidenbauer, Sabine; Hohmann, Carsten; Kornack, Daniel; Lagdali, Nadia; Mueller, Lukas; Osterloh-Konrad, Christine; Pohlhausen, Carlo; Redeker, Philipp; and Röder, Erik. Debt and Equity: What's the Difference? A Comparative View, Max Planck Institute for Intellectual Property, Competition \& Tax Law, Research Paper No. 09-09, 2009

Schoueri, Luis Eduardo. Tax sparing: a reconsideration of the reconsideration in Tax. Law and Development, edited by Brauner, Yariv; and Stewart, Miranda. Edward Elgar Publishing, 2013.

Silberztein, Caroline; and Tristram, Jean-Baptiste. OECD: Multilateral Instrument to Implement BEPS. IBFD, International Transfer Pricing Journal, 2016.

Soto, Marcelo. Capital Flows and Growth in Developing Countries: Recent Empirical Evidence, OECD Development Centre, Working Paper $N^{\circ} 160,2000$.

Souza de Man, Fernando. Taxation of Cross-Border Provisions of Services in Double Tax Conventions between Developed and Developing Countries: A Proposalfor New Guidelines. PhD Thesis Maastricht University, Faculty of Law, 2013. 
Taylor, C. John. Twilight of the Neanderthals, or Are Bilateral Double Taxation Treaty Networks Sustainable?. Melbourne University Law Review, Vol 34, 2010.

Thuronyi, Victor. Tax Treaties and Developing Countries in Tax Treaties: Building Bridges between Law and Economics. IBFD, 2010

Toaze, Deborah. Tax Sparing: Good Intentions, Unintended Results. Canadian Tax Journal, Vol 49, 2001.

Valdés-Prieto, Salvador and Soto, Marcelo. The Effectiveness of Capital Controls: Theory and Evidence from Chile, 1998.

Vallejo Chamorro, José María; and Gutiérrez Lousa, Manuel. Los convenios para evitar la doble imposición: Análisis de sus ventajas e inconvenientes, 2002.

Van de Vijver, Anne. The New US-Belgium Double Tax Treaty: A Belgian and EU Perspective, Belgium, Larcier, 2009.

Van der Bruggen. Citing for the OECD quote, OECD Report on Fiscal Incentives for Private Investment in Developing Countries (1965), British Tax Review 119, 2002.

Vogel, Klaus, Double Tax Treaties and Their Interpretation. International Tax \& Business Lawyer, Vol 4, 1986.

Vogel, Klaus. Worldwide vs source taxation of income - A review and re-evaluation of arguments. Intertax, Vol 16, 1988

Vogel, Klaus. Worldwide vs. Source taxation of income: A review and reevaluation of arguments. Influence of Tax Differentials on International Competitiveness. VIII Munich Symposium on International Taxation, Kluwer Law and Taxation Publishers, Deventer Boston, 1990. 
von Schanz, George. Zur Frage der Steuerpflicht (Regarding Tax Liability), Vol 9 Finanzarchiv, 1892.

Wang, Ke Chin. International Double Taxation of Income: Relief Through International Agreement 1921-1945. Harvard Law Review, Vol 59, 1945.

Ward, David. Access to Treaty Benefits. Research Report Prepared for the Advisory Panel on Canada's System of International Taxation, 2008.

Watson, John. Multinationals and the great tax debate: a view from industry. Tolley \& Lexis RPSL Tax, 2013.

Whittaker, Donald R. An examination of the O.E.C.D. and U.N. model tax treaties: history, provisions and application to U.S. foreign policy. North Carolina Journal of International Law and Commercial Regulation, Vol 8, 1982.

Zee, Howell H. Taxation of Financial Capital in a Globalized Environment: The role of withholding taxes. National Tax Journal, Vol 51, 1998

Zimmer, Frederik. Withholding taxes. University of Oslo, 2008.

\section{BOOKS AND BOOK SECTIONS}

Alm, James; Martinez-Vasquez, Jorge; and Rider, Mark (eds.). The Challenges of Tax Reform in a Global Economy. Springer, 2006.

Arnold, Brian; and Barnes, Peter. Protecting the Tax Base of Developing Countries against Base-eroding Payments: Interest and Other Financing Expenses. United Nations, 2017. 
Ault, Hugh J; and Arnolds, Brian J. Protecting the Tax Base of developing countries. Chapter I of the United Nations Handbook on Selected Issues, Edited by Alexander Trepelkov, Harry Tonino and Dominika Halka, New York, 2017.

Avi-Yonah, Reuven S. Double Tax Treaties: An Introduction. University of Michigan Law School, 2007.

Boulle, Laurence; Laryea, Emmanuel; and Sucker, Franziska (eds.). International Economic Law and African Development. Siber Ink, South Africa, 2014.

Brealey, Richard; Myers, Stewart; and Allen, Franklin. Principles of Corporate Finance, $11^{\text {th }}$ ed., United States, McGraw-Hill/Irwin, 2013.

Buitrago Diaz, Esperanza. El Concepto de Cánones y/o Regalías en los Convenios para Evitar la Doble Imposición sobre la Renta, CISS-Kluwer, Spain, 2007.

Buitrago Diaz, Esperanza. El concepto de cánones y/o regalías en los Convenios para Evitar la Doble Imposición sobre la Renta, Valencia: Revista de Derecho Fiscal, 2007.

Copeland, Thomas E., Weston J. Fred, and Shastri, Kuldeep. Financial Theory and Corporate Policy. $4^{\text {th }}$ ed., New Jersey: Prentice Hall, 2003.

Finnerty, Chris J; and Merks, Paulus. Fundamentals of International Tax Planning. IBFD, 2007.

Gerendy, Zoltan. The future of source taxation at passive income in: Tax Treaty Policy and Development. Vienna: Linde Verlag, 2005.

Holmes, Kevin. International Tax Policy and Double Tax Treaties: An Introduction to Principles and Application. IBFD, 2007.

Kemmeren, Eric C.C.M. Principle of Origin in Tax Conventions: A Rethinking of Models, The Netherlands, Pijnenburg, 2001. 
Lang, Michael. Introduction to the Law of Double Taxation Conventions, $2^{\text {nd }}$ ed. Linde, 2010.

Lang, Michael; Pistone, Pasquale; Schuch, Josef; Staringer, Claus; Storck, Alfred; and Zagler, Martin. Tax Treaties: Building Bridges between Law and Economics. IBFD, 2010.

OECD Glossary of Foreign Direct Investment Terms and Definitions.

OECD Glossary of Tax Terms.

Olivier, Lynette; and Honiball, Michael. International Tax: A South African Perspective, $5^{\text {th }}$ ed., 2011.

Serrani, Esteban; with collaboration of Falco, Adrian. Acuerdos para Evitar la Doble Tributación en América Latina. Análisis de los vínculos entre los impuestos, el comercio y las finanzas responsables. Fundación SES Buenos Aires Red Latindadd, 2013.

Schreiber, Ulrich. International Company Taxation: An Introduction to the Legal and Economic Principles. Springer Texts in Business and Economics, 2013.

Thuronyi, Victor. Comparative Tax Law. Kluwer Law International, 2003.

Pistone, Pasquale; and Goodspeed, Timothy J. Rethinking tax jurisdictions and relief from international double taxation in relations with developing countries: Legal and economic perspectives from Europe and North America. International Tax Coordination, An Interdisciplinary Perspective on Virtues and Pitfalls, edited by Martin Zagler, 2010.

Tirole, Jean. The Theory of Corporate Finance, United Kingdom, Princeton University Press, 2006.

United Nations, Handbook on Selected Issues in Administration of Double Tax Treaties for Developing Countries, edited by Alexander Trepelkov, Harry Tonino and Dominika Halka. 2013.

Valdés Costa. Estudios de Derecho Tributario Internacional, Montevideo, 1978

Valdés Costa. Instituciones de Derecho Tributario, Buenos Aires, 1992

Vogel, Klaus. Klaus Vogel on Double Taxation Conventions, 3rd ed., 1997. 
Zagler, Martin. Tax Treaties: Building Bridges between Law and Economics. IBFD, 2010.

\section{Law, Conventions, Resolutions AND Legal Regulation}

Council Directive (EU), 2003/123/EC, December 22, 2003, amending Directive 90/435/EEC on the common system of taxation applicable in the case of parent companies and subsidiaries of different Member States.

Council Directive (EU) 2015/121, of 27 January 2015, amending Directive 2011/96/EU on the common system of taxation applicable in the case of parent companies and subsidiaries of different Member States.

Council Directive (EU), 1990/435/EEC, July 23, 1990, on the common system of taxation applicable in the case of parent companies and subsidiaries of different Member States.

Council Directive (EU), 2003/49/EC, June 3, 2003, on a common system of taxation applicable to interest and royalty payments made between associated companies of different Member States. Article 3 letter $b$.

Council Directive (EU) 2014/86, of 8 July 2014, amending Directive 2011/96/EU on the common system of taxation applicable in the case of parent companies and subsidiaries of different Member States.

Council Directive (EU) 2016/1164, of 12 July 2016, laying down rules against tax avoidance practices that directly affect the functioning of the internal market.

Double Tax Convention between Bahrain and The Netherlands, 2008.

Double Tax Convention between Macedonia and The Netherlands, 1998.

Double Tax Convention between Georgia and The Netherlands, 2002. 
Double Tax Convention between Kuwait and The Netherlands, 2001.

Double Tax Convention between Republic of Chile and Australia, 2010.

Double Tax Convention between Republic of Chile and Austria, 2012.

Double Tax Convention between Republic of Chile and Belgium, 2017.

Double Tax Convention between Republic of Chile and Brazil, 2001.

Double Tax Convention between Republic of Chile and Canada, 1998.

Double Tax Convention between Republic of Chile and Colombia, 2007.

Double Tax Convention between Republic of Chile and Republic of Korea, 2003.

Double Tax Convention between Republic of Chile and Croatia, 2003.

Double Tax Convention between Republic of Chile and Denmark, 2005.

Double Tax Convention between Republic of Chile and Ecuador, 1999.

Double Tax Convention between Republic of Chile and Spain, 2003.

Double Tax Convention between Republic of Chile and France. 2004.

Double Tax Convention between Republic of Chile and Ireland, 2005.

Double Tax Convention between Republic of Chile and Malaysia, 2004.

Double Tax Convention between Republic of Chile and New Zealand, 2003. 
Double Tax Convention between Republic of Chile and Paraguay, 2005.

Double Tax Convention between Republic of Chile and Peru, 2001.

Double Tax Convention between Republic of Chile and Poland, 2004.

Double Tax Convention between Republic of Chile and Portugal, 2005.

Double Tax Convention between Republic of Chile and United Kingdom of Great Britain and Northern Ireland, 2003.

Double Tax Convention between Republic of Chile and Russia, 2004.

Double Tax Convention between Republic of Chile and Sweden, 2004.

Double Tax Convention between Republic of Chile and Switzerland, 2008.

Double Tax Convention between Republic of Chile and Thailand, 2006.

Protocol of the Double Tax Convention between the United States of America and the Federal Republic of Germany, 1989.

Treaty between Austria-Hungary and Prussia for the Avoidance of Double Taxation, 1899.

Treaty between Italy - Czechoslovakia for the Prevention of Double Taxation and the Settlement of other Questions concerning Direct Taxation, 1924. Final Protocol, 1925.

Unites States Internal Revenue Code, 952. Subpart F. 
United States of America, Public Law 115-97 known as “Tax Cuts and Jobs Act 2017”. New Code section 245A.

United Nations, Economic and Social Council, Resolution 1273 (XLIII), E/4429, 1967.

Vienna Convention on the Law of Treaties, 1969.

\section{DOCUMENTS FROM INTERNATIONAL INSTITUTIONS}

Andean Community, Decision 40 (MTC - Cartagena Agreement), 1971

ECOSOC. Committee of Experts on International Cooperation in Tax Matters Twelfth Session, Discussion of substantive issues related to international cooperation in tax matters: article 12: general consideration, including equipment-related issues, 2014

ECOSOC. Committee of Experts on International Cooperation in Tax Matters Twelfth Session, Possible Amendments to the Commentary on Article 12 (Royalties), Note by the Coordinator, Ms. Pragya Saksena, 2014

European Commission. COM (2012) 722/2. Communication from the Commission to the European Parliament and the Council - An Action Plan to strengthen the fight against tax fraud and tax evasion.

European Commission. (2012) 8806. Commission Recommendation.

India. Report of the High-Powered Committee on Electronic Commerce and Taxation, 2001, Annex 2

International Chamber of Commerce, Resolution $\mathrm{N}^{\circ} 11$ of the Constituent Congress, 1920.

International Monetary Fund. World Economic Outlook. Subdued Demand: Symptoms and Remedies, 2016.

International Monetary Fund. World Economic and Financial Survey. World Economic Outlook Database, 2013.

International Monetary Fund. Tax Policy, Leverage and Macroeconomic Stability, 2016

Japanese Tax Commission. Basic Idea for Fundamental Reform of Tax System, 2007. 
League of Nations, Fiscal Committee. Report to the Council on the fifth session of the Committee, Annex I: Revised text of the Draft Convention for the allocation of business income between States for the purpose of taxation, Geneva, 1935.

League of Nations, Model Bilateral Convention for the Prevention of the Double Taxation of Income (Mexico Model), 1943.

League of Nations, Economic and Financial Commission, Professors Bruins, Einaudi, Seligman, and Sir Josiah Stamp. Report on Double Taxation submitted to the Financial Committee, 1923.

League of Nations, Model Tax Convention, No. 1 A, 1928.

League of Nations, Technical Experts to the Economic and Financial Committee. Double Taxation and Tax Evasion. Report and Resolutions submitted by the Technical Experts to the Financial Committee, 1925.

OECD BEPS Project, Action Plan on Base Erosion and Profit Shifting, 2013.

OECD BEPS Project: Final Reports, 2015.

OECD BEPS Project: Final Report Action 2: Neutralizing the Effects of Hybrid Mismatch Arrangements, 2015.

OECD BEPS Project: Final Report Action 3: Designing Effective Controlled Foreign Company Rules, 2015.

OECD BEPS Project: Final Report Action 4: Limiting Base Erosion Involving Interest Deductions and Other Financial Payments, 2015.

OECD BEPS Project: Final Report Action 5: Countering Harmful Tax Practices More Effectively, Taking into Account Transparency and Substance, 2015.

OECD BEPS Project: Final Report Action 6: Preventing the Granting of Treaty Benefits in Inappropriate Circumstances, 2015.

OECD BEPS Project: Multilateral Convention to Implement Tax Treaty Related Measures to Prevent BEPS, 2016.

OECD BEPS Project: Public Discussion Draft BEPS Action 4, Interest deductions and other financial payments. December 2014 - February 2015.

OECD BEPS Project: Public Discussion Draft Actions 8-10, 2018.

OECD, Fiscal Incentives for Private Investment in developing Countries: Report of the OECD Fiscal Committee, 1965. para. 164. 
OECD, Foreign Direct Investment for Development. Maximising Benefits, Minimising Costs. Overview, 2002.

OECD, Global Forum on International Investment. Attracting Foreign Direct Investment for Development, 2002.

OECD, Global Forum on Transparency and Exchange of Information for Tax Purposes, 2009.

OECD, G20, Explanatory Statement BEPS Project, Final Reports, 2015.

OECD, Direct taxation of Patent Royalties and similar payments (Note by the Secretariat), 1958.

OECD, Making Dispute Resolution Mechanisms More Effective, 2015.

OECD, Model Tax Convention on Income and Capital, 1963.

OECD, Model Tax Convention on Income and Capital, 1977.

OECD, Model Tax Convention on Income and Capital, 1992.

OECD, Model Tax Convention on Income and Capital, 2010.

OECD, Model Tax Convention on Income and Capital, 2017.

OECD. Tax Treaty Characterisation Issues Arising from E-Commerce and Taxation, 2001. Report issued by the Technical Advisory Group on Treaty Characterisation of Electronic Commerce Payments to Working Party $N^{\circ} 1$ of the OECD Committee on Fiscal Affairs, 2001, Annex 2.

OECD, Working Party No. 8 of the Fiscal Committee (Germany and Luxemburg). Report on the direct taxation of Patent Royalties and similar payments, 1958.

OECD. Working Party No. 12 of the Fiscal Committee (Germany - Italy - Switzerland). Report on the taxation of Dividends, 1958.

OECD, Working Party No. 11 of the Fiscal Committee (France and Belgium). Report on the taxation of Interest, 1959. 
OECD, Working Party No. 12 of the Fiscal Committee (Germany - Italy - Switzerland). Second Report on the taxation of Dividends, 1960.

OECD, Working Party No. 8 of the Fiscal Committee (Germany and Luxemburg). Revised Third Report on the taxation of Royalties, 1961.

OECD, Working Party No. 8 of the Fiscal Committee (Germany and Luxemburg). Revised Fourth Report on the taxation of Royalties, 1961.

OECD, Council, Report of the Fiscal Committee on the Draft Convention for the Avoidance of Double Taxation with respect to taxes on Income and Capital among the Member Countries of the O.E.C.D, 1963.

OEEC. Fourth Report by the Fiscal Committee, The Elimination of Double Taxation, 1961.

President's Advisory Panel on Federal Tax Reform. Simple, Fair \& Pro-Growth: Proposal to Fix America's Tax System, United States of America, 2005.

UNCTAD: Bilateral Investment Treaties in the Mid 1990s, 1998.

UNCTAD: Comprehensive Study of the Interrelationship between Foreign Direct Investment (FDI) and Foreign Portfolio Investment (FPI), 1998.

UNCTAD. The role of International Investment agreements in attracting foreign direct investment to developing countries, New York and Geneva, 2009

UNCTAD, World Investment Report, 2014.

UNCTAD, World Investment Report, 2015.

UNCTAD, World Investment Report, 2016 
UNCTAD, World Investment Report, 2017.

UNCTAD, World Investment Report, 2020.

United Nations BEPS Project: Proposed BEPS-related Changes to the United Nations Model Double Taxation Convention between Developed and Developing Countries. Report by Coordinator Carmel Peters. Committee of Experts on International Cooperation in Tax Matters, Twelfth Session, 2016.

United Nations BEPS Project: Taxation of Services. Report by Coordinator Liselott Kana. Committee of Experts on International Cooperation in Tax Matters, Seventh Session, 2016.

United Nations, Committee of Experts on International Cooperation in Tax Matters Twelfth Session, 2016.

United Nations, Committee of Experts on International Cooperation in Tax Matters, Eleventh Session, Geneva, October 2015.

United Nations, Department of Economic and Social Affairs, Guidelines for Tax Treaties Between Developed and Developing Countries, New York, 1974.

United Nations, Department of Economic and Social Affairs, Guidelines for Tax Treaties Between Developed and Developing Countries, 2016.

United Nations, Department of Economic and Social Affairs, Division for Public Administration and Development Management, Manual for the Negotiation of Bilateral tax Treaties between Developed and Developing Countries, 2003. 
United Nations, Department of Economic and Social Affairs, Division for Public Administration and Development Management. Manual for the Negotiation of Bilateral tax Treaties between Developed and Developing Countries, 2019.

United Nations, Department of Economic and Social Affairs, Model Double Taxation Convention between Developed and Developing Countries, 1980.

United Nations, Department of Economic and Social Affairs, Model Double Taxation Convention between Developed and Developing Countries, 2017.

United Nations, Economic and Social Council, Resolution 1273, 1967 United Nations, General Assembly, Declaration on the Right to Development, Document A/RES/41/128, Geneva, 1986.

United Nations, Human Development Report, 2002.

United Nations, Human Rights, The Right to Development at a glance, 2011.

World Economic Forum, The Global Competitiveness Report, 2016-2017 


\section{Curriculum Vitae}

Gonzalo Garfias von Fürstenberg was born on 10 July 1979 in Santiago, Chile. Successfully completing the Law Degree at Pontificia Universidad Católica de Chile, he obtained an LL.M in Tax at Universidad Adolfo Ibañez and an LL.M in International and European Tax Law at Maastricht University. As a full-time PhD researcher (2013 - 2015) and as a part-time PhD researcher (2016-2020) at the Faculty of Law of Maastricht University, Gonzalo wrote this dissertation under the supervision of Prof. Dr. Rainer Prokisch and Prof. Dr Hans van den Hurk. He joined the firm of Allende Bascuñan \& Cía in Santiago, Chile in 2016 as Tax partner. In 2020, with two other partners and two associates, he formed a new tax law firm, Garfias \& Cía in Santiago, Chile. 